\title{
National Register of Historic Places Eligibility Testing of Site 41SM385 Within TxD0T's Tyler District, Smith County, Texas
}

Michael A. Nash

Linda W. Ellis

Candace L. Wallace

Erin K. Watkins

Follow this and additional works at: https://scholarworks.sfasu.edu/ita

Part of the American Material Culture Commons, Archaeological Anthropology Commons, Environmental Studies Commons, Other American Studies Commons, Other Arts and Humanities Commons, Other History of Art, Architecture, and Archaeology Commons, and the United States History Commons

Tell us how this article helped you.

This Article is brought to you for free and open access by the Center for Regional Heritage Research at SFA ScholarWorks. It has been accepted for inclusion in Index of Texas Archaeology: Open Access Gray Literature from the Lone Star State by an authorized editor of SFA ScholarWorks. For more information, please contact cdsscholarworks@sfasu.edu. 


\section{National Register of Historic Places Eligibility Testing of Site 41SM385 Within TxDOT's Tyler District, Smith County, Texas}

\section{Licensing Statement}

This is a work for hire produced for the Texas Department of Transportation (TxDOT), which owns all rights, title, and interest in and to all data and other information developed for this project under its contract with the report producer. The report may be cited and brief passages from this publication may be reproduced without permission provided that credit is given to TxDOT and the firm that produced it. Permission to reprint an entire chapter, section, figures or tables must be obtained in advance from the Supervisor of the Archeological Studies Branch, Environmental Affairs Division, Texas Department of Transportation, 125 East 11th Street, Austin, Texas, 78701 
National Register of Historic Places

Eligibility Testing of Site 41SM385

Within TxDOT's Tyler District

Smith County, Texas

Texas Antiquities Permit No. 5190

CSJ 3487-01-004, LP 49 West, Section $3 A$ 
Document No. 110016

PBS\&J Job No. 0480013

\title{
National Register of Historic Places ELIGIBILITY TESTING OF SITE 41SM385 WITHIN TXDOT'S TYLER DISTRICT SMith County, Texas
}

Texas Antiquities Permit No. 5190

\section{CSJ 3487-01-004, LP 49 WESt, SECTION 3A}

Prepared for:

\author{
North East Texas Regional Mobility Authority \\ 305 South Broadway Avenue \\ Suite 100 \\ Tyler, Texas 75702
}

Prepared by:

$$
\begin{gathered}
\text { PBS\&J, an Atkins company } \\
6504 \text { Bridge Point Parkway } \\
\text { Suite } 200 \\
\text { Austin, Texas } 78730
\end{gathered}
$$

Principal Investigator:

Maynard B. Cliff

\author{
Report Authors: \\ Michael A. Nash \\ Linda W. Ellis \\ Candace L. Wallace \\ Erin K. Watkins
}

May 2011 


\begin{abstract}
PBS\&J, an Atkins company, was contracted by the North East Texas Regional Mobility Authority to conduct National Register of Historic Places eligibility testing of site 41SM385, a prehistoric campsite on a small rise above the floodplain of Indian Creek in western Smith County, Texas. Testing investigations were conducted during March and September 2009. The site was subjected to a systematic program of shovel testing, mechanical trenching, and hand excavation in an effort to identify cultural features or living surfaces and optimize recovery of diagnostic faunal, floral, and artifactual remains.

The recovered cultural artifacts indicate that site 41SM385 represents a probable Woodland and Caddo-aged occupation on a small rise on the creek floodplain. The Woodland component is based on recovered small Gary and Kent projectile points characteristic of Woodland culture of the region. The Caddo component is based on ceramic sherds of probable Early or Middle Caddo origin identified at the site. Radiocarbon dating of four ceramic sherds supports these assessments with three sherds dating to the Early to Middle Caddo periods and one sherd dating to the Woodland period. The lack of identified cultural features suggests that the Woodland component probably represents a series of ephemeral usages of the location, probably as short-term campsites. The Caddo-aged artifacts at the site probably represent a series of ephemeral usage of the location, either as a resource procurement locus ancillary to nearby site 41 SM404 or as a short-term campsite.
\end{abstract}

The testing program failed to locate living surfaces or cultural features containing in situ artifactual or organic remains preserved on the site. The absence of cultural features and the paucity of lithic tools or ceramic remains make more-meaningful functional interpretation infeasible. For this reason, the site lacks the data resources that would warrant National Register of Historic Places listing or designation as a State Archeological Landmark. No further work is recommended. 


\section{Contents}

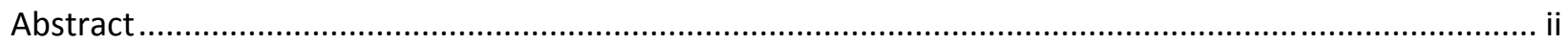

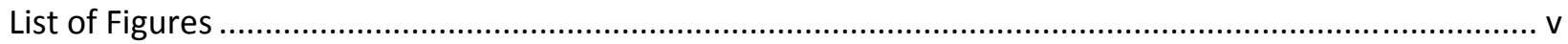

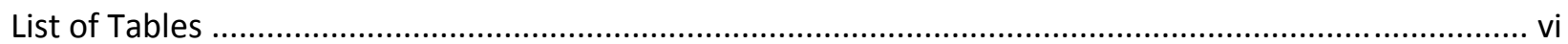

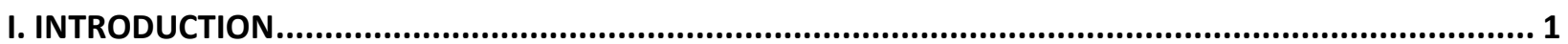

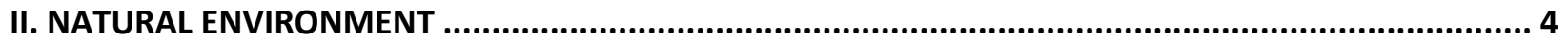

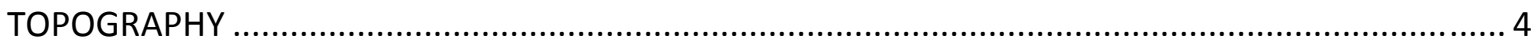

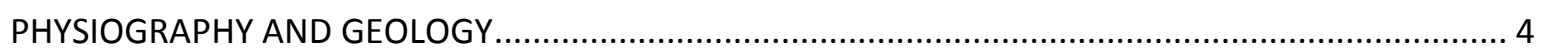

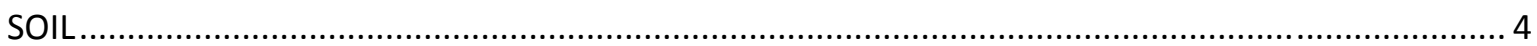

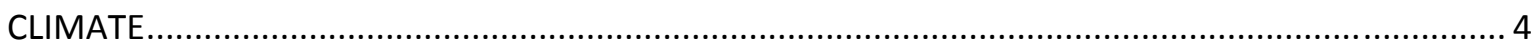

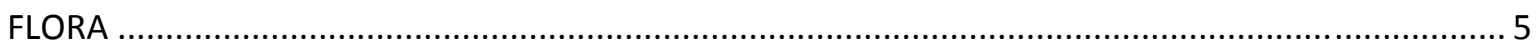

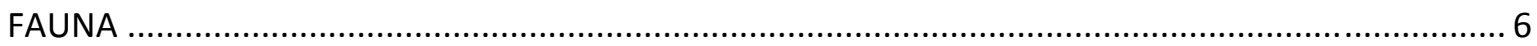

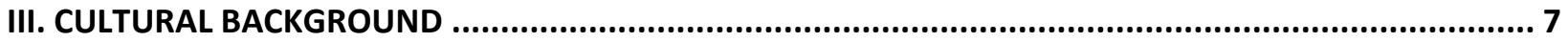

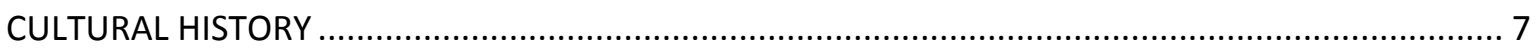

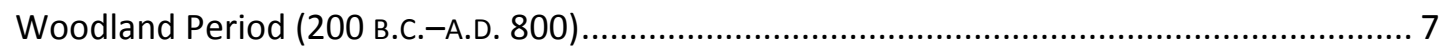

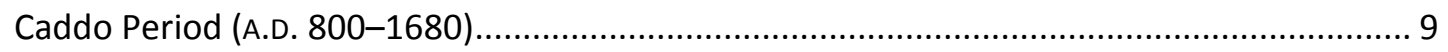

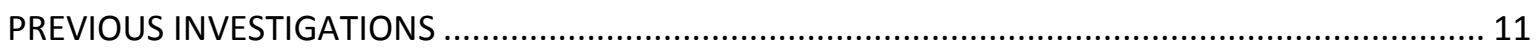

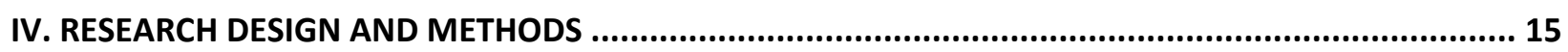

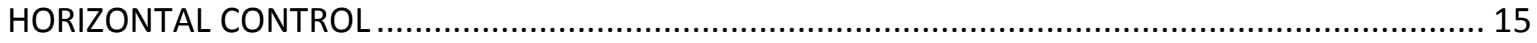

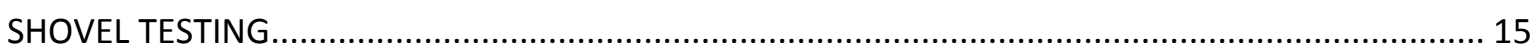

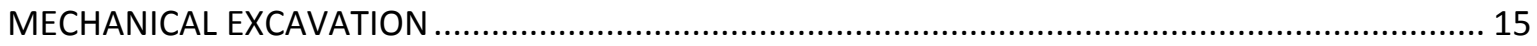

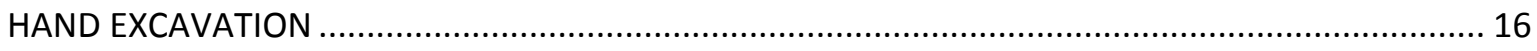

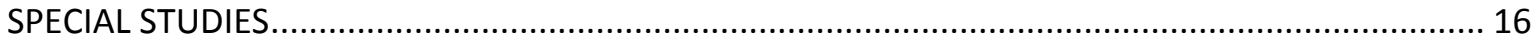

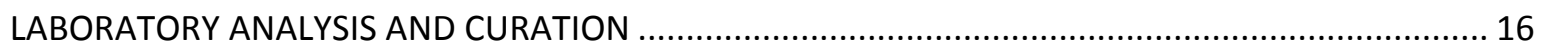

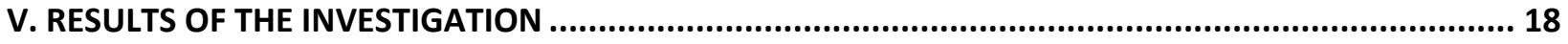

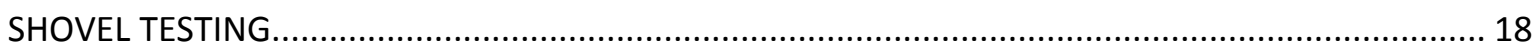

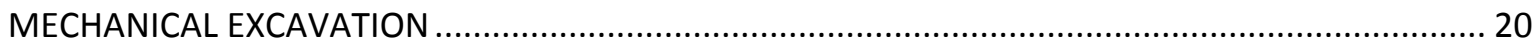

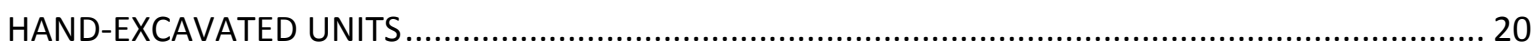

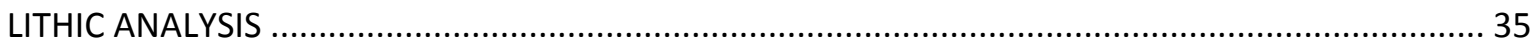

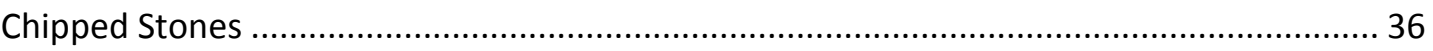

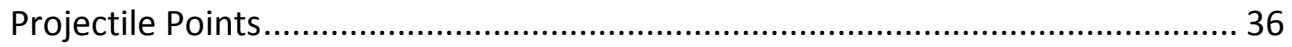

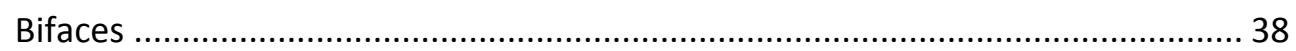

Unifacially Modified and Utilized Flakes ........................................................... 38

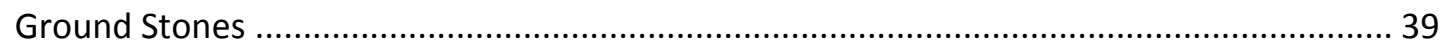

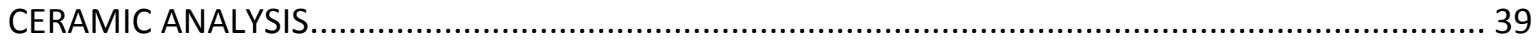

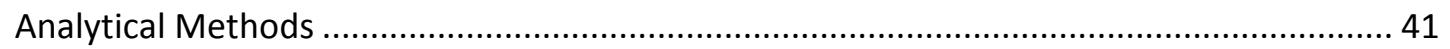

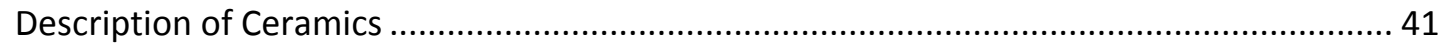

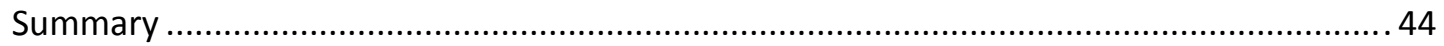




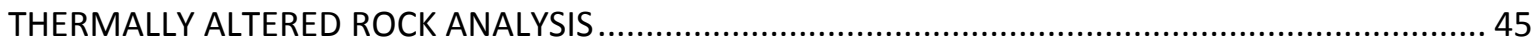

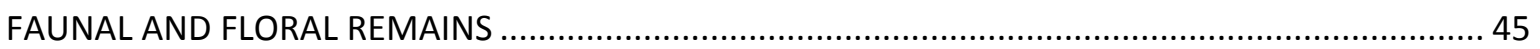

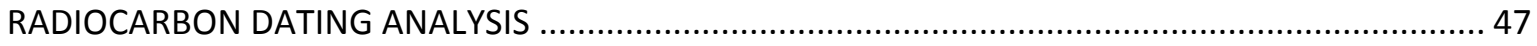

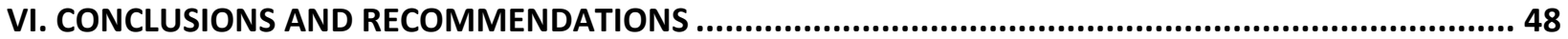

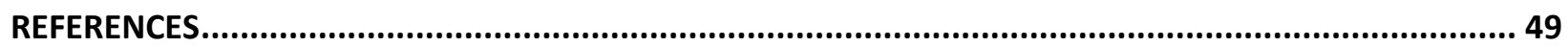

Appendices:

A Specimen Inventory (on CD)

B Lithic Analysis (on CD)

C Radiocarbon Dating Analysis

D Site Location (not for public disclosure) 


\section{Figures}

Page

1

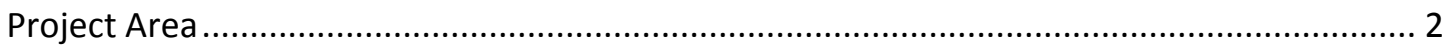

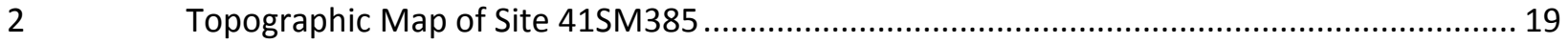

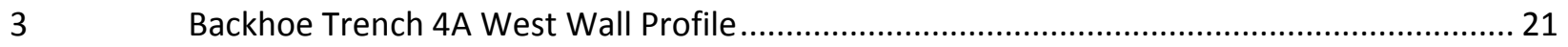

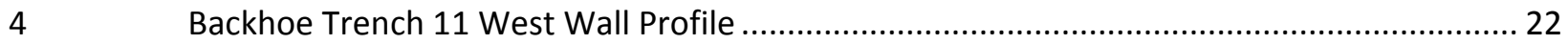

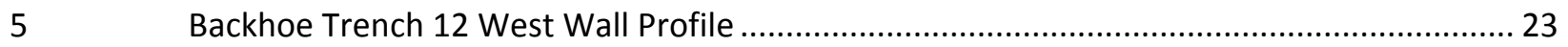

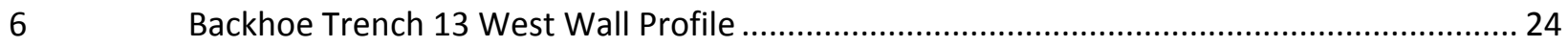

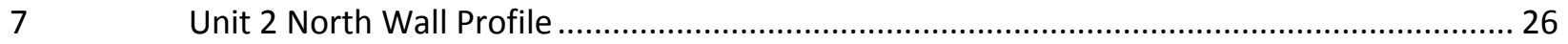

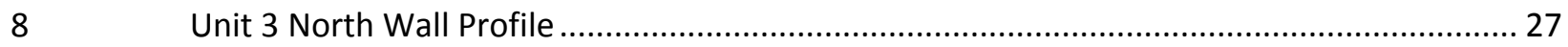

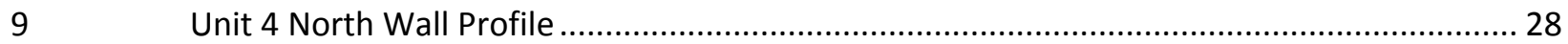

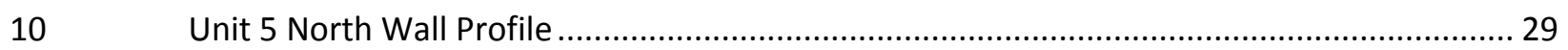

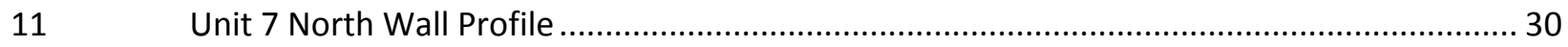

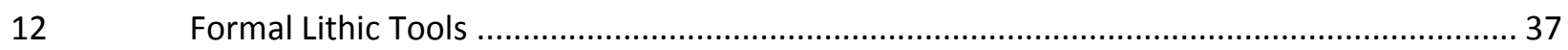

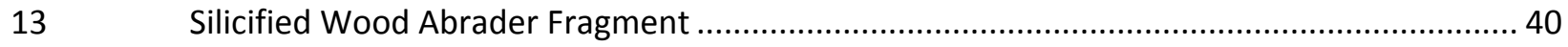

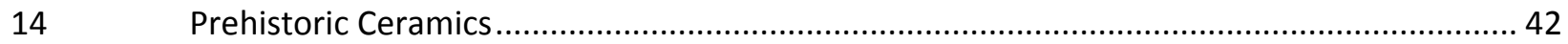




\section{Tables}

Page

$1 \quad$ Cultural Sequence for Northeast Texas....................................................................... 7

$2 \quad$ Termination of Shovel Tests, Test Units, and Backhoe Trenches......................................... 18

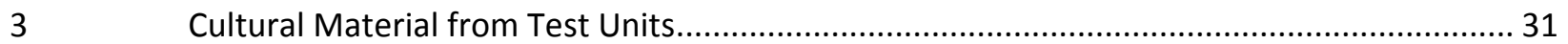

$4 \quad$ Summary Chipped Lithic Tools Recovered in NRHP Testing of Site 41SM385 ...................... 36

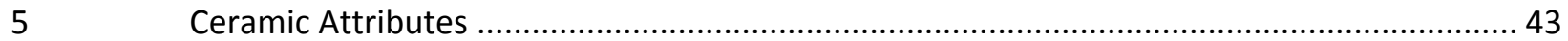

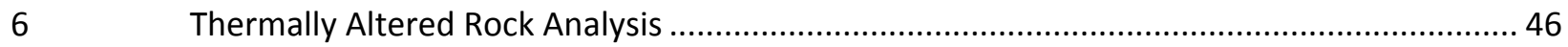




\section{INTRODUCTION}

PBS\&J, an Atkins company, was contracted by the North East Texas Regional Mobility Authority (NET RMA) to undertake archeological investigations for proposed Toll 49, Segment 3A, between State Highway (SH) 31 on the north, at about 6 miles (9.7 kilometers) west of Loop 323, and SH 155 on the south, at about 5.25 miles (8.5 kilometers) southwest of Loop 323 in Smith County, Texas. The project involves the construction of two lanes of an ultimate four-lane facility and includes the construction of a two-lane, rural typical section (two 12-foot [3.6 meters (m)] lanes and 10-foot [3.0 m] shoulders on each side). From north to south, bridge work will include the construction of bridges at SH 31, County Road (CR) 1134/waterway structure (Indian Creek)/UPRR, waterway structure at station 725+00, CR 1227, CR 1130, Butler Creek, CR 1113/waterway structure, waterway structure at station 850+50, CR 196, and SH 155.

At the request of the NET RMA, PBS\&J conducted National Register of Historic Places (NRHP) eligibility testing of prehistoric site 41SM385 during March and September 2009. The site is situated within the floodplain of Indian Creek, in western Smith County (Figure 1).

The site is located completely within the right of way (ROW) of the proposed highway bypass project near its eastern edge. However, the entire site has been fenced off and removed from the project's area of potential effect so no effect of the project to the site is anticipated.

In order to determine the NRHP eligibility of site 41SM385, the site was subjected to a systematic program of shovel testing, mechanical trenching, and hand excavation in an effort to optimize recovery of artifacts, faunal and macrofloral remains, and cultural features. This work demonstrated that living surfaces containing in situ artifactual remains, faunal and macrofloral remains, and cultural features have not been preserved on the site. For this reason, the site lacks the data resources that would warrant NRHP inclusion. No further work is recommended.

These investigations were performed in compliance with the Texas Antiquities Code of 1977, as revised through 1995 (Texas Natural Resources Code: Title 9, Chapter 191), and the National Historic Preservation Act of 1966, as amended through 1992 (PL 89-665 through PL 102-575; 80 Stat. 915; 16 USC $§ 470$ et seq.). Finally, the work was conducted in accordance with the guidelines set forth by the Council of Texas Archeologists (1995), under the supervision of the Texas Department of Transportation (TxDOT).

Approximately 65 person-days of labor were expended during the fieldwork. The project was conducted under the direction of Principal Investigator Maynard Cliff and the direct supervision of Project Archeologist Michael Nash. The field crew included Randy Norris, Lynne O’Kelly, Julie Shipp, Tina Golgoun, Sara Laurence, Philip Washington, Ryan Schuermann, Meghan Egan, Rae Weir, Erin Watkins, and Karen Belvin. 


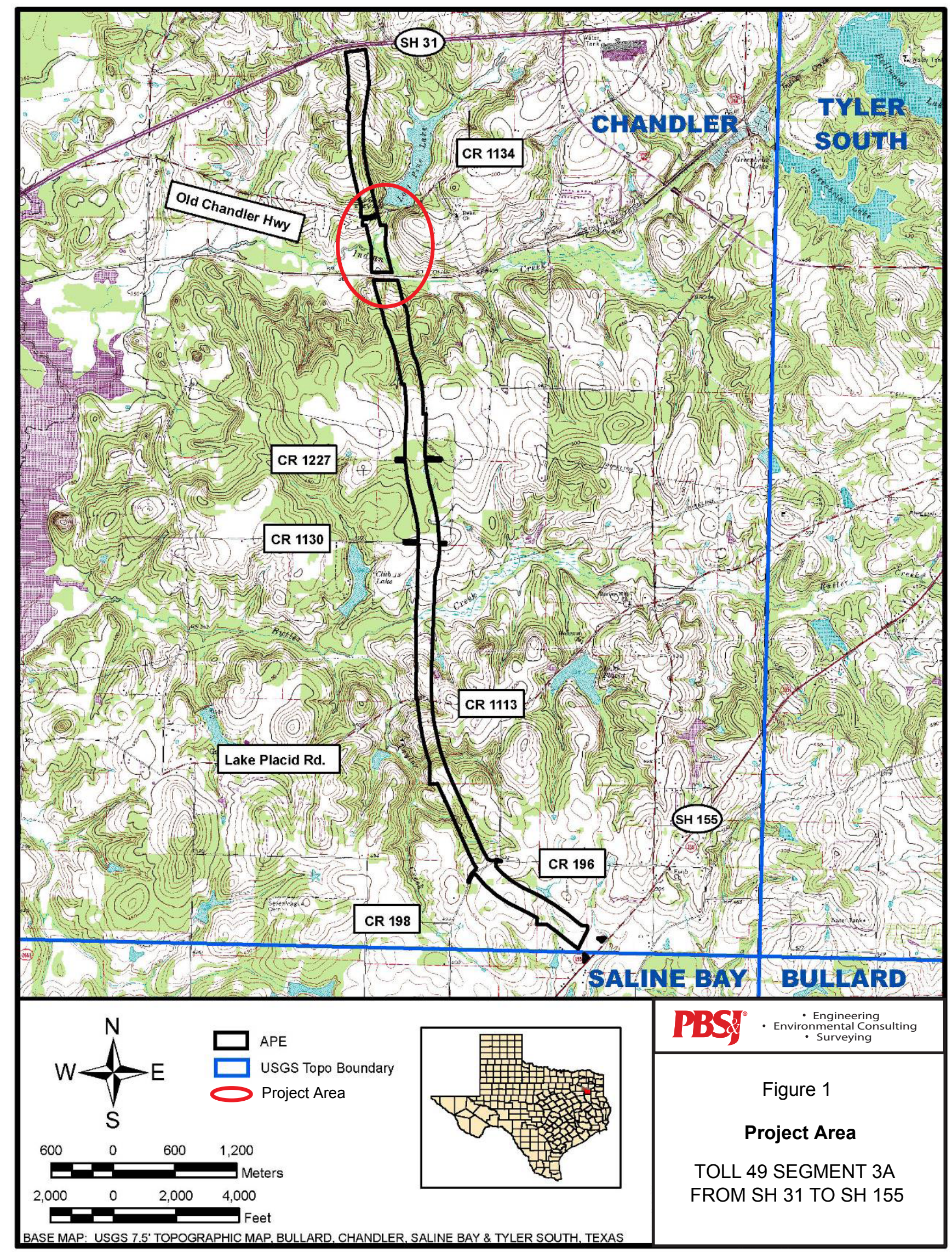


This report is divided into six sections. Following this introduction, sections II and III discuss the general environmental setting and the cultural background of site 41SM385. Section IV presents the research design and methods for the fieldwork, and Section $V$ presents results of the investigation. Section VI provides a summary of the cultural resource management recommendations. A list of references cited follows the text. A specimen inventory of collected material is presented in Appendix A, and tabular data on lithic artifacts are presented in Appendix B. Appendix C presents the radiocarbon dating analysis, and Appendix D contains a map showing the location of site 41SM385; for the purpose of confidentiality, this map had been removed from copies of the report intended for public distribution. 


\section{NATURAL ENVIRONMENT}

\section{TOPOGRAPHY}

Site 41SM385 is located on a small low rise at the eastern edge of the floodplain of Indian Creek. The site is approximately $100 \mathrm{~m}(330 \mathrm{ft})$ north-northeast of the present creek channel at its closest point. It is at an approximate elevation of $364 \mathrm{ft}$ above sea level. The site is typically inundated by seasonal flooding of the creek most years. A small seasonal slough of the creek lies immediately south-southwest of the site. Site 41SM385 is vegetated with a variety of short to tall grasses with scattered thistles and nettles. Mixed pine-hardwood timber is located across a fence east of the site, and scattered mature hardwoods are located around the site, including a very large elm tree at the site's northwestern edge. Modern disturbances to the site include the clearing of most of the timber vegetation that covered the site followed by grass cultivation.

\section{PHYSIOGRAPHY AND GEOLOGY}

Site 41SM385 is physiographically in a transitional area between the Pineywoods and the Post Oak Savannah natural regions of Texas. Geologically, the site is situated within a belt of geologically recent alluvium along Indian Creek. Immediately outside of this recent alluvium, the area is mapped as the Eocene-aged Sparta Sand, with limited outcrops of the stratigraphically lower Weches Formation and a belt of recent alluvium along Indian Creek (Bureau of Economic Geology [BEG] 1965). The Sparta Sand consists of fine- to medium-grained, light gray to brownish gray, quartz sand with interbeds of sandy clay and hard ferruginous sandstone at the base (BEG 1965). The Weches Formation consists of a grayish green to grayish olive-green, thin-bedded glauconite and quartz sand with clay interbeds (BEG 1965).

\section{SOIL}

The surface soil in this area is mapped as Mantachie loam, frequently flooded. Mantachie soils have recently been reclassified as Inceptisols (Soil Survey Staff 2004). Specifically they are Fluventic Endoaquepts, which are very deep, somewhat poorly drained loamy soils formed in loamy alluvial sediments of Holocene age. They are frequently flooded between November and May, are strongly acidic, poorly drained, and have a water table usually within 18 inches (46 centimeters [cm]) of the surface during winter months (U.S. Department of Agriculture, Soil Conservation Service [USDA, SCS] 1993:33-35). These characteristics are not conducive to the preservation of cultural features and/or subsistence remains at prehistoric sites.

\section{CLIMATE}

The climate of Smith County is humid and subtropical with long hot summers, cool fairly short winters, and fairly heavy precipitation throughout the year (USDA, SCS 1993). During the spring, summer, and fall seasons, air masses off the Gulf of Mexico dominate, while during the winter, the 
climate is significantly affected by cold arctic air masses. Monthly temperatures for Smith County, recorded in Tyler for the period from 1954 to 1981, range from an average of 7.7 degrees Celsius $\left.{ }^{\circ} \mathrm{C}\right)$ (46 degrees Fahrenheit [ $\left.\left.{ }^{\circ} \mathrm{F}\right]\right)$ during the winter, to an average of $26.6^{\circ} \mathrm{C}\left(80^{\circ} \mathrm{F}\right)$ during the summer, with a typical growing season of about 228 days (USDA, SCS 1993:110-111).

The average annual precipitation of Smith County is about 44 inches $(112 \mathrm{~cm})$, about half of which usually falls between April and September. July and August are the two driest months of the year. The average rainfall during these two months drops to 2.64 inches $(6.7 \mathrm{~cm})$, while April has the highest average rainfall, 5.04 inches $(12.8 \mathrm{~cm})$. Thunderstorms are most common in the spring, occurring on about 44 days of each year. Snowfall averages about 2 inches $(5.0 \mathrm{~cm})$ a year (USDA, SCS 1993:110-111).

\section{FLORA}

The site is located within a transitional area between the Piney Woods and Post Oak Savannah ecoregions (Texas Parks and Wildlife Department [TPWD] 2004). The vegetation, as indicated by TPWD's Vegetation Types of Texas (TPWD 1984), consists largely of Pine-Hardwood Forest and pasture consisting of Other Native and/or Introduced Grasses in the uplands and upper floodplains, and Willow-Water Oak-Blackgum Forest in the lower floodplains (McMahan et al. 1984), most of which has been cleared in proximity to site 41SM385. The Pine-Hardwood Forest in Smith County is classified as Subtype 2: Shortleaf Pine-Post Oak-Southern Red Oak Forest (McMahan et al. 1984). Commonly associated plants include loblolly pine (Pinus taeda), black hickory (Carya texana), sandjack oak (Quercus incana), flowering dogwood (Cornus florida), common persimmon (Diospyros virginiana), sweetgum (Liquidambar styraciflua), sassafras (Sassafras albidum), greenbriar (Smilax spp.), yaupon (Ilex vomitoria), wax myrtle (Myrica spp.), American beautyberry (Callicarpa americana), hawthorn (Crataegus spp.), supplejack (Berchemia scandens), winged elm (Ulmus alata), beaked panicum (Panicum anceps), spranglegrass (Leptochloa spp.), indiangrass (Sorghastrum nutans), switchgrass (Panicum virgatum), three-awn (Aristida spp.), bushclover (Cuscuta spp.), and tickclover (Desmodium spp.) (McMahan et al. 1984:25).

The Willow-Water Oak-Blackgum Forest commonly includes beech (Fagus grandifolia), overcup oak (Quercus lyrata), chestnut oak (Quercus muehlenbergii), cherrybark oak (Quercus pagoda), elm (Ulmus sp.), sweetgum, sycamore (Plantanus occidentalis), southern magnolia (Magnolia grandiflora), white oak (Quercus alba), black willow (Salix nigra), bald cypress (Taxodium distichum), swamp laurel oak (Quercus laurifolia), hawthorn, bush palmetto (Sabal minor), common elderberry (Sambucus canadensis), southern arrowwood (Viburnum dentatum), poison oak (Toxicodendron pubescens), supplejack, trumpet creeper (Campsis radicans), crossvine (Bignonia capreolata), greenbriar, blackberry (Rubus fruticosus), rhomboid copperleaf (Acalypha rhomboidea), and St. Andrew's Cross (Ascyrum hypericoides). 


\section{FAUNA}

The site is located within the Austroriparian biotic province, as defined by Blair (1950), and is bordered on the west by the Texan biotic province. Davis and Schmidly (1994) divide Texas into four faunal regions based on the ecological distribution of mammals within the state. Smith County falls within the East Texas region. This region includes the Pineywoods, the Central Texas Woodlands, the Blackland Prairies, and the Coastal Prairies and Marshes.

Animal species that may have been important for food, shelter, and clothing to prehistoric and early historic inhabitants of this area include bison (Bos bison), rabbit (Sylvilagus spp.), fox squirrel (Sciurus niger), raccoon (Procyon lotor), Virginia opossum (Didelphis virginiana), white-tailed deer (Odocoileus virginianus), beaver (Castor canadensis), black bear (Ursus americanus), and diverse rodent fauna (Davis and Schmidly 1994). Important birds that occur in the area include turkey (Meleagris gallopavo), quail (Colinus virginianus), and the prairie chicken (Tympanuchus cupido) (Skokan et al. 1997). In addition to birds and mammals, fish, such as gar (Lepisosteus sp.), bowfin (Amia calva), pickerel (Esox sp.), catfish (Ictaluridae) and bass (Centrarchidae), and reptiles and amphibians, including turtles (Testudinata), particularly the snapping turtle (Chelydra serpentina), lizards (Iguanidae), snakes (Colubridae), and frogs (Ranidae), were also exploited (Perttula and Bruseth 1983; Swanton 1942). 


\section{CULTURAL BACKGROUND}

\section{CULTURAL HISTORY}

Site 41SM385 lies within the Northeast Texas Archeological Region, as defined by the Texas Historical Commission (THC) (Kenmotsu and Perttula 1993). The general cultural history of this area, based on previous research, can be divided into five primary chronological and developmental periods - Paleoindian, Archaic, Woodland, Caddo, and Historic (Table 1). These divisions are believed to reflect changes in subsistence and cultural development as reflected by material remains and settlement patterns. The following discussion of these periods draws on previous summaries by Perttula (1988, 1995), Story (1981, 1985, 1990), and Thurmond (1985, 1988, 1990). Because site $41 \mathrm{SM} 385$ is associated with the Woodland and Caddo periods, only these are discussed in this section.

Table 1

Cultural Sequence for Northeast Texas

(after Perttula and Kenmotsu 1993; Story 1990)

\begin{tabular}{ll}
\hline \multicolumn{1}{c}{ Period } & \multicolumn{1}{c}{ Approximate Dates } \\
\hline Paleoindian & $9500-7000$ B.C. \\
Archaic & $7000-200$ B.C. \\
Woodland & 200 B.C. - A.D. 800 \\
Caddo & \\
Formative & A.D. $800-1000$ \\
Early & A.D. $1000-1200$ \\
Middle & A.D. $1200-1400$ \\
Late & A.D. $1400-1680$ \\
Historic & post-A.D. 1680 \\
\hline
\end{tabular}

\section{Woodland Period (200 B.C.-A.D. 800)}

Three cultural expressions have been proposed to characterize the Woodland period in east Texas - Fourche Maline, centering on the Great Bend of the Red River in Arkansas and extending into adjacent Oklahoma, Louisiana, and northeast Texas to include the Lower and Middle Sulphur River basin; Mossy Grove, centered in southeast Texas and extending up the Angelina-Neches and Trinity River basins; and, most recently, Mill Creek, centering on the Upper Sabine River basin (Black and Story 2003).

Fourche Maline sites in northeast Texas are generally characterized by coarse plainware ceramics, tempered with either clay/grog or bone, known as Williams Plain; Gary dart points; and, 
subsequently, corner-notched arrow points (Perttula 1995:335; Thurmond 1990). Despite similarities to Fourche Maline in Arkansas, Woodland period burial mounds do not appear to be present in northeast Texas.

The Mossy Grove tradition is characterized by sandy paste ceramics (cf. Bear Creek Plain and Goose Creek Plain) that are common on Woodland period sites from the Sabine River south to the Gulf Coast (Story 1981:146). Characteristic projectile points include small Gary and Kent dart points and, after A.D. 500-600, expanding-stem arrow points such as Friley and Scallorn (Black and Story 2003). The few burial mounds that are known from east Texas occur in the Sabine and Neches River basins around the Toledo Bend Reservoir and Lake Sam Rayburn areas, respectively, and are probably related to Mossy Grove (see Story 1990:Figure 42).

The Mill Creek culture has been identified west and south of the Red and Sulphur River basins, and specifically, in the upper Sabine River basin (Black and Story 2003). Mill Creek sites appear to be smaller than the Arkansas Fourche Maline sites and contain less pottery. The pottery that is present is thinner than typical Williams Plain and is more often decorated with incised lines, punctations, and other techniques. Mill Creek sites lack burial mounds, and the lithic assemblages are characterized by small Gary and Kent dart points that are replaced by expanding-stem arrow points after about A.D. 600-700 (Black and Story 2003). The best-known Mill Creek site is the Herman Ballew site (41RK222), excavated by PBS\&J archeologists in 1993-1994 (Rogers et al. 2001).

In addition to local ceramics, Lower Mississippi Valley ceramic types, such as Tchefuncte Stamped, Churupa Incised, Marksville Incised, Troyville Stamped, and Marksville Stamped, have been recovered from Woodland period contexts at a number of sites, especially in the Sabine River basin (Perttula 1995:335-336; Story 1990:246). This, together with the occurrence of burial mounds in this same general area, suggests a long tradition of contact between east Texas and the Lower Mississippi Valley, by way of central Louisiana.

By the end of the Woodland period, Coles Creek ceramics are present in the Sabine River drainage, along with expanding-stem arrow points similar to the Colbert and Friley types (Perttula 1995:336). Coles Creek ceramics and expanding-stem arrow points have been dated to between about 1,000 and 1,300 years ago at the James Pace site (16DS268) at Toledo Bend Reservoir in DeSoto Parish, Louisiana (Girard 1994; Perttula 1995:336). Material of equivalent age from Lake Fork Reservoir, in the Upper Sabine River basin, consists of "ceramic assemblages dominated by horizontally incised decorative motifs, and Friley arrow points" (Perttula 1995:336; see also Bruseth and Perttula 1981).

Woodland components have also been identified at the Resch site (41HS16) in southern Harrison County (Webb et al. 1969), the Folley site (41RK26) in northeastern Rusk County (Jarvis 1972), and the Yarborough site (41VN6) in Van Zandt County (Bruseth and Perttula 1981; Johnson 1962; Perttula and Skiles 1988). Generally, these sites can be dated to the Woodland period on the basis 
of the presence of Lower Mississippi Valley ceramics such as the Tchefuncte, Marksville, and Coles Creek types.

\section{Caddo Period (A.D. 800-1680)}

The Caddo period in east Texas in general has been subdivided into Formative (A.D. 800-1000), Early (A.D. 1000-1200), Middle (A.D. 1200-1400), and Late (A.D. 1400-1680) subperiods. The chronology used here is based on the work of Perttula (1995) and Thurmond (1990) in the Sabine River and Cypress Creek basins, north of site 41SM385's location. Both the Formative and Early Caddo periods include components related to the more traditional Alto and Sanders foci in eastern Texas. The ceramic types characteristic of the Formative Caddo are Holly Fine Engraved, Hickory Fine Engraved, Spiro Engraved, Kiam Incised, Weches Fingernail Impressed, and Coles Creek Incised, with Williams Plain also being present (Thurmond 1990). Ceramic types characteristic of the Early Caddo period include Sanders Engraved, Hickory Fine Engraved, Sanders Plain, and Canton Incised, with Williams Plain making up a smaller part of the assemblage than previously (Thurmond 1990:226-227).

Arrow points for the Formative to Early Caddo periods include Alba, Bonham, Catahoula, and Scallorn types (Thurmond 1990:226-227). The Formative Caddo period is suggested to be the earliest true Caddo cultural configuration (Story 1972). The George C. Davis site (41CE19) on the Neches River is probably the most important site for this period. Small Formative Caddo sites are generally located on terraces adjacent to water resources. Major Formative Caddo mound centers are located in major river valleys such as the South Sulphur River.

Sites of the Early Caddo period are more widespread and are typically found on terraces and on knolls near water resources. Subsistence during both the Formative and Early Caddo periods was probably based primarily on the hunting of deer and small mammals, supplemented by horticulture. Maize has been recovered from Early Caddo occupations, and settlement patterns are thought to reflect a wide population dispersal into sedentary hamlets and farmsteads (Perttula et al. 1986:54-55).

Judging from radiocarbon dates, Middle Caddo period occupations are more common throughout much of northeast Texas in comparison to Formative and Early Caddo occupations. Middle Caddo period sites continue to be located on elevated landforms adjacent to major streams, as well as along minor tributaries and spring-fed drainages (Perttula 2004:378-379). Ceramic types identified for the Middle Caddo period include Ripley Engraved, Avery Engraved, Canton Incised, Maydelle Incised, Bullard Brushed, Pease Brushed-Incised, and La Rue Neck Banded (Thurmond 1990:227-228). In the Sabine River and Cypress Creek basins, the brushing of utilityware vessels became common after A.D. 1300 (Perttula 1995:338). Projectile points identified as being characteristic of the period include Bonham, Catahoula, Alba, Perdiz, and Cliffton (Thurmond 1990:227-228). In the Sabine River basin, the Middle Caddo component at the Oak Hill Village site 
(41RK214) is estimated to date between about A.D. 1200/1300 and 1450 (Rogers and Perttula 2004). Middle Caddo sites in Smith County include the Bryan Hardy site (41SM55), the Redwine site (41SM193), and the Langford site (41SM197) (Middlebrook and Perttula 1997; Walters 1997; Walters and Haskins 2000).

Smith County falls within what Shafer has recently termed the Northern Prairie Caddo geographic area (Shafer 2006:Figure 1). Shafer (2006) proposes a model for identifying what he calls Prairie Caddo using material culture occurring in east-central Texas from approximately A.D. 1000 to 1300. In this model, he argues that some Caddo groups, while associated with neighboring Caddo in the woodlands to the east, adapted to life in the prairies of central Texas using a distinctive technological style. His list of material remains that might be used to identify Prairie Caddo sites includes ceramics and human remains identified as Caddo, Gahagan biface knives, Bonham-Alba arrow points, bone needles, and deer metapodial beamers (Shafer 2006).

Thurmond (1990) observes that ca. A.D 1400, the elements of Caddo material culture, manifested archeologically in ceramic and projectile point assemblages, differentiate along a line drawn roughly north to south somewhat west of Caddo Lake in Harrison County, Texas. The observed differences west to east are hypothesized by Thurmond (1990) to represent probable social groups.

The Late Caddo period appears to be notable for an increase in regional variants (see Perttula 2004:Figure 13.26). The western portion of the Cypress Creek basin and the middle Sabine basin, north of site 41SM385, were characterized by the Whelan and Titus phases. The Whelan phase (ca. A.D. 1350-1450) is the earlier of these two and is largely confined to the Cypress Creek drainage basin (Thurmond 1985:Figure 4). Ceramics from Whelan phase sites include Ripley Engraved, Taylor Engraved, Wilder Engraved, Bullard Brushed, Pease Brushed-Incised, Maydelle Incised, and La Rue Neck Banded. Perdiz and Scallorn arrow points are generally associated with the Whelan phase (Thurmond 1990:228).

The succeeding Titus phase (ca. A.D. 1450-1650) represents the final prehistoric occupation of the upper Cypress Creek basin. Perttula (1995:338) describes the Titus phase as representing "the archeological remains of a number of Caddo groups who lived between the Sabine and Sulphur rivers." Ceramics characteristic of the Titus phase include Ripley Engraved, Taylor Engraved, Wilder Engraved, Bailey Engraved, Johns Engraved, Bullard Brushed, Harleton Appliqué, Maydelle Incised, La Rue Neck-Banded, McKinney Plain, and Killough Pinched. Arrow points are primarily Bassett, Maud, Reed, and Talco (Thurmond 1990:228-229).

Another Late Caddo grouping, identified as the Frankston phase (ca. A.D. 1400-1650), is located in the Neches and Angelina River basins in Smith, Henderson, Cherokee, and Van Zandt counties (Perttula 2004:395). Frankston phase sites include farmsteads, hamlets, and small villages. One Frankston phase mound is known, at the A.C. Saunders site (41AN19) in Anderson County (Jackson 1936; Kleinschmidt 1982). Small scattered hamlets with one to three houses have been identified in 
the upper Neches River basin (Anderson et al. 1974:178-180). The ceramic inventory of the Frankston phase includes Poynor Engraved, Bullard Brushed, Maydelle Incised, and La Rue NeckBanded. Elbow pipes and Perdiz arrow points are also present.

A third Late Caddo group, identified as the Angelina phase (ca. A.D. 1450-1650), is centered between the Angelina and Sabine rivers, in the vicinity of Lake Sam Rayburn (Perttula 2004:395). The Walter Bell site (41SB50) is an Angelina phase site that contained small midden deposits, circular structures, and a small cemetery with extended and flexed burials (Perttula and Black 2003). Artifacts at the site included Perdiz arrow points, conch shell beads, bone tools, mussel shells, and incised bird-bone flutes (Perttula and Black 2003). Ceramics associated with Angelina phase sites largely consist of Pineland Punctated-Incised and Broaddus Brushed (Jelks 1965:214; Wyckoff 1974:206).

\section{PREVIOUS INVESTIGATIONS}

Smith County attracted little interest from early archeologists until the 1930s, when J.E. Pearce, the founder of the Department of Anthropology at the University of Texas, arranged for expanded archeological work in Texas, much of which was centered in east Texas. In 1935, Walter Goldschmidt prepared a synthesis of archeological sites in Titus County and their relationship to other sites in east Texas (Goldschmidt 1935). The importance of this early work is that it was one of the first attempts at defining a chronological framework for the region. In Smith County, Jack Hughes recorded 45 sites from 1938 to 1943 (Kleinschmidt 1982).

In the decades after the Second World War, archeological research in the region was, for the most part, related to investigations along waterways for reservoir development. Cedar Creek Reservoir, on the western side of Henderson County in the middle Trinity River basin, was surveyed in 1961, 1963, and 1964 by the Texas Archeological Salvage Project. Three sites were excavated in 1964 by Dee Ann Story (Story 1965). In 1957, E.B. Jelks conducted a survey of Blackburn Crossing Reservoir (present-day Lake Palestine) in Anderson, Cherokee, Henderson, and Smith counties, in the Upper Neches River basin. He recorded one site (41SM73) in Smith County. The Joe Meyer site was a Late Caddo cemetery that at one time contained over 20 burials (Jelks 1958; Johnson 1958, 1961). A later survey conducted by Southern Methodist University in 1969 and 1970 for the enlargement of Lake Palestine located 98 sites, including 41 in Henderson County, 28 in Smith County, 10 in Anderson County, and 15 in Cherokee County (Anderson 1971; Anderson et al. 1974). These sites ranged in age from the Middle Archaic to Late Caddo, with Caddo sites exhibiting ceramics from both the Alto and Frankston phases (Anderson et al. 1974). Other reservoir studies conducted within the Neches-Angelina River basin include Lake Athens (Duffield 1960) and the proposed Ponca Reservoir (Skinner 1971a). Investigations associated with reservoir projects within the Sabine River basin include Lake Tawakoni (formerly Iron Bridge Reservoir) (Duffield 1961; Duffield and Jelks 1961; Johnson 1957), Lake Mineola (Carl Estes Reservoir) (Malone 1972), Lake Fork Reservoir (Bruseth 1975; Bruseth et al. 1977; Skiles 1978; Skinner 1971b, 1975), proposed 
Big Sandy Reservoir (Gibson 1982; Perttula et al. 1986), and proposed Water's Bluff Reservoir (Perttula 1986).

Nonreservoir cultural resource management work pertinent to the current project has been conducted in association with power generation projects, water pipeline projects, park expansions, well pads, and power transmission projects. The State Department of Highways and Public Transportation conducted numerous surveys in the county from 1973 to 1979, but no cultural resource sites were recorded. Alan Skinner recorded 8 Civil War commercial salt-manufacturing furnace locations and 10 furnaces along the Neches-Saline (Skinner 1971c).

In 1977, W.H. Whitsett recorded three prehistoric sites (41SM94, 41SM95, and 41SM96) during a survey for the Texas Water Quality Board and the City of Tyler (Whitsett 1977). Of the three, only 41SM94, a multicomponent site, was found to contain Caddo pottery. Nash et al. (1993) recorded three sites (41SM174, 41SM175, and 41SM180) during a cultural resources survey for a proposed transmission line. Site 41SM174 was recorded as an unknown prehistoric campsite, while sites 41SM175 and 41SM180 were historic period house sites. Schmidt (1996) recorded three sites (41SM200, 41SM201, and 41SM202) during a cultural resources survey for the East Texas Electric Cooperative. Site 41SM201 was found to be multicomponent with both historic and prehistoric artifacts, while 41SM200 and 41SM202 were both historic period sites.

An archeological survey of Tyler State Park, conducted by TPWD (Howard et al. 1995), resulted in the recording of six sites (41SM184, 41SM185, 41SM186, 41SM187, 41SM188, and 41SM189), of which two (41SM184 and 41SM189) were designated State Archeological Landmarks (SALs). Site 41SM184 was determined to be a Late Caddo campsite, while 41 SM189 was found to be the remnant of a Civilian Conservation Corps camp from the 1930s. The remaining four sites consisted of late-nineteenth- to early-twentieth-century wells, dumps, and habitations.

In 1999, Alan Skinner recorded three historic period sites during archeological investigations at Faulkner Park and Pounds Field Airport (Skinner 1999a, 1999b). Two of these (41SM235 and 41SM236) were recorded at Faulkner Park, and included a mid to late 1800s house site and an early 1900s foundation for the Harris Chapel School. The third site (41SM242) consisted of the remains of a World War II-period barracks from Tyler Army Airfield. That same year, Perttula and Nelson (1999) conducted an archeological survey for the proposed Starrville Water Supply waterline and recorded three prehistoric lithic scatters of indeterminate date (41SM227, 41SM228, and 41SM229). In 2003, archeological investigations were conducted at the Lindsey Park site (41SM300) by Archeological \& Environmental Consultants (Perttula et al. 2003). Site 41SM300 was found to be a multicomponent site that was occupied from the Late Archaic to Woodland periods, with an apparent reoccupation during the Late Caddo period. The excavations resulted in the recovery of a burial, two chert dart points, a mano/pitted stone, lithic debris, wood charcoal, and nutshells (Perttula et al. 2003). Radiocarbon dates suggested that the burial was affiliated with the Frankston phase (ca. A.D. 1400-1615). Archeological surveys of several well pads at Lake Tyler East, 
conducted by Archeological \& Environmental Consultants (Perttula and Nelson 2004a, 2005), recorded four prehistoric sites in the Angelina drainage basin (41SM209, 41SM213, 41SM332, and 41SM333). Sites 41SM209 and 41SM213 were judged to be Caddo sites, while the other two were of indeterminate age.

Perttula and Nelson also conducted several archeological investigations for the City of Tyler-Lake Palestine Water Treatment Pipeline project (Perttula and Nelson 2000, 2001a, 2001b, 2004b). Eight cultural resource sites were recorded (41SM203, 41SM271, 41SM272, 41SM273, 41SM274, 41SM275, 41SM281, and 41SM291), two of which had Caddo components. Test excavations were later conducted at the Prestonwood site (41SM272) and the Broadway site (41SM273) (Perttula and Nelson 2001a, 2004b). Site 41SM272 was found to be a multicomponent prehistoric site with Paleoindian, Archaic, and Caddo artifacts, while 41SM273 yielded Late Caddo pottery.

Other projects in the county include assessment work on mound sites in the Sabine River basin and various other archeological testing projects. In the 1980s, Tim Perttula conducted a survey for Caddo mound sites within the Sabine River basin in east Texas and adjacent portions of northwestern Louisiana (Perttula 1989). Three mound sites (41SM54, 41SM55, and 41SM62) were identified in Smith County - 41SM54 (the Jamestown site), 41SM55 (the Bryan Hardy site), and 41SM62. The Jamestown site appears to be a multi-mound site dating to the Middle Caddo period and is presently listed as a SAL. The Bryan Hardy site is another Middle Caddo mound site, while 41SM62 was recorded as a possible mound site by Robert Mallouf and Dee Ann Story in 1978.

In 1997, test excavations were conducted by Nancy Kenmotsu at 41SM203 for TxDOT. Site 41SM203 was found to be a Late Archaic to Late Prehistoric campsite with only a small amount of Caddo pottery (Goode 1997). In 2001, TxDOT conducted archeological testing at site 41SM231 for the South Tyler Greenbelt project. The site was determined to be an Early to Middle Caddo campsite and yielded 98 shell-and-grog-tempered plainware sherds (Ahr 2001).

In 1997 and 1998, archeological investigations were conducted at Camp Ford (41SM181), a Confederate prisoner of war (POW) camp, presently listed as a SAL. Archeological fieldwork for the Camp Ford Archaeological and Historical project included test excavations and remote sensing (Thoms 2004). Site 41SM181 was found to contain over 80 subsurface features, including slave-dug footing trenches for the stockade walls, POW-built houses, refuse pits, drainage ditches, and latrine features. Artifacts recovered from the excavations included military buttons, insignia fragments, bullets, and pieces of ceramics and glass (Thoms 2004).

In 2007, an archeological survey with geoarcheological investigations was conducted by PBS\&J for Proposed Loop 49, Segment 3A (Pemberton et al. 2009). The investigation included pedestrian survey of the proposed ROW between SH 155 on the south and SH 31 on the north, and geoarcheological investigation within the floodplain of Indian Creek. Four new archeological sites were recorded (41SM372, 41SM373, 41SM374, and 41SM385). These included two prehistoric 
sites (41SM372 and 41SM385) and two historic sites (41SM373 and 41SM374). Only one site was recommended for further archeological assessment (41SM385).

Site 41SM385 was identified in two backhoe trenches during Phase I investigations in the floodplain north of Indian Creek, at the proposed crossing of Toll 49, Segment 3A (Pemberton et al. 2009). Four trenches (4-7) were excavated to investigate a very low rise, believed to be an old levee remnant, immediately north of a shallow slough, which was thought to represent a relict channel of the creek. Two of the trenches ( 4 and 5) were culturally positive. Nine prehistoric lithic artifacts, including a biface fragment and eight debitage fragments, and small fragments of charcoal were present in two backhoe trenches and one $50-\mathrm{x}-50-\mathrm{cm}$ test unit adjacent to one of the trenches. 


\section{RESEARCH DESIGN AND METHODS}

The testing strategy was designed to determine whether the site harbors significant data resources that meet the criteria warranting inclusion in the NRHP. Such resources may include intact cultural features or deposits that maintain integrity of design and materials and are likely to yield information important to prehistory. This work complies with applicable standards as defined or referenced in 13 TAC 26.20 and THC policy.

The field investigations were conducted in three stages: systematic shovel testing, judgmentally placed mechanical excavations, and hand excavation. Horizontal control was maintained with a total station established over a site datum. All shovel tests, trenches, and hand excavation units were tied to the site datum with the total station. The total station was also used to map the site's topography.

\section{HORIZONTAL CONTROL}

A control grid with 10-m grid intercepts oriented parallel to the proposed ROW edge was established on the site. The control grid encompassed the site boundaries as defined during the initial survey and recordation and allowed for possible site boundary expansion. All shovel tests, backhoe trenches, and hand excavation units were tied to the grid with a total station.

\section{SHOVEL TESTING}

During the first stage of the investigations, site 41SM385 was subjected to a systematic program of shovel testing in order to evaluate the horizontal and vertical distribution of artifacts across the site and determine whether behaviorally meaningful patterns of discard, such as activity areas, were preserved at the site. This effort was designed to horizontally identify and define individual site components and activity areas as well as areas having a high probability for cultural features. Shovel tests measuring approximately $30 \mathrm{~cm}$ in diameter and $1 \mathrm{~m}$ in depth were excavated during two phases. During the first phase, shovel tests were excavated at 10-m grid intercepts across the site to broadly define artifact density clines. During the second phase, shovel tests were primarily excavated at 5-m grid intercepts between previously excavated shovel tests within high artifact density and diversity areas defined during the first stage. A total of 54 shovel tests were excavated during the investigation. All shovel tests were excavated in arbitrary $10-\mathrm{cm}$ levels and screened with $1 / 4$-inch-mesh hardware cloth.

\section{MECHANICAL EXCAVATION}

Five backhoe trenches were used to sample areas of high artifact density and to expose a representative cross section of the site. Trench walls were cleaned with hand tools and closely examined to determine whether cultural features were present. A representative profile was drawn of each trench, and a portion of the corresponding trench wall was photographed. The goal of this 
effort was to search for intact cultural features and deposits and to expose an intermittent stratigraphic profile of the site.

\section{HAND EXCAVATION}

Nine 1-x-1-m test units were excavated in arbitrary 10 -cm levels with a total volume of $10.4 \mathrm{~m}^{3}$ excavated at site 41SM385. As a specification of the scope of work included in the Texas Antiquities Permit, $3 \mathrm{~m}^{3}$ of hand excavation were to be devoted to investigating an apparent hearth feature in Trench 5 found during trenching associated with intensive survey investigations (Pemberton et al. 2009:62-63), misidentified as Trench 4 in the scope of work for testing of 41SM385. After reopening and extending Trench 5 and excavation of test units 6 and 7 as close as possible to the possible hearth feature, given the slumping of Trench 5, it was determined that the reddish brown to strong brown compact sand zone underlying a black manganese zone thought to be a cultural feature was generally ubiquitous in this portion of the site and contained no more fire-cracked rock, or charcoal than the zones above and below it. The remainder of the test units were used to sample high artifact density and diversity areas and to search for intact cultural features. They were placed according to the field director's judgment, based on the results of shovel testing and trench excavation, to optimize the potential for the location of cultural features and recovery of artifacts and faunal and macrobotanical remains. Units 1-5 were placed in the area of the site with the highest density of cultural material first identified in Shovel Test 23. Units 8 and 9 were placed to sample a location of relatively high artifact density in the southern part of the site.

\section{SPECIAL STUDIES}

During the field investigation, soil samples were collected for possible radiocarbon dating or special studies. Special studies that were considered during the analysis phase of the project include particle-size analysis and magnetic susceptibility. However, given the absence of cultural features or defined living surfaces identified during field investigations, no special studies were conducted and the only radiocarbon dating was of selected ceramic sherds.

\section{LABORATORY ANALYSIS AND CURATION}

All recovered artifacts were brought back to the PBS\&J laboratory for analysis and preparation for curation. All artifacts have been washed, cataloged, and labeled in compliance with Texas Archeological Research Laboratory (TARL) standards. All recovered artifacts, field notes, and records will be curated at TARL.

The assemblage of lithic tools was examined under low-power microscopy in order to identify patterns of use wear. Morphological characteristics of projectile points were used to identify cultural affiliation and assess manufacturing techniques when possible. Lithic debitage was classified in categories reflecting state of reduction. The entire lithic assemblage, including tools and debitage, was classified into raw material categories and evaluated for thermo-alteration. 
For ceramic sherds, technological attributes recorded for sherds of sufficient size included (1) paste constituency (i.e., identification of the type of nonplastic inclusions [i.e., sand, bone, grog]), the predominant size range of nonplastic inclusions [i.e., medium sand, fine sand, very fine sand], and texture; (2) exterior and interior surface treatment; (3) exterior and interior decorative treatment; (4) morphological class (i.e., body, base, or rim); (5) average thickness; and (6) firing environment (i.e., oxidizing vs. nonoxidizing). 


\section{RESULTS OF THE INVESTIGATION}

\section{SHOVEL TESTING}

The site was systematically sampled with 54 shovel tests at $10-\mathrm{m}$ and $5-\mathrm{m}$ grid intercepts covering the site area (Figure 2). The soil encountered in shovel tests generally consisted of a loose to slightly firm, very fine sandy loam. Excavation of each shovel test to a depth of at least 80 centimeters below the surface (cmbs) was attempted. The depth of shovel tests ranged from 50 to $100 \mathrm{cmbs}$, averaging approximately $92 \mathrm{cmbs}$ (Table 2).

Table 2: Termination Depth of Shovel Tests, Test Units, and Backhoe Trenches

\begin{tabular}{|c|c|c|c|c|c|}
\hline Unit No. & $\begin{array}{l}\text { Termination } \\
\text { Depth in cmbs }\end{array}$ & Unit No. & $\begin{array}{l}\text { Termination } \\
\text { Depth in cmbs }\end{array}$ & Unit No. & $\begin{array}{l}\text { Termination } \\
\text { Depth in cmbs }\end{array}$ \\
\hline Shovel Test 1 & 80 & Shovel Test 24 & 90 & Shovel Test 47 & 80 \\
\hline Shovel Test 2 & 50 & Shovel Test 25 & 80 & Shovel Test 48 & 100 \\
\hline Shovel Test 3 & 90 & Shovel Test 26 & 80 & Shovel Test 49 & 100 \\
\hline Shovel Test 4 & 90 & Shovel Test 27 & 100 & Shovel Test 50 & 90 \\
\hline Shovel Test 5 & 90 & Shovel Test 28 & 90 & Shovel Test 51 & 100 \\
\hline Shovel Test 6 & 90 & Shovel Test 29 & 90 & Shovel Test 52 & 90 \\
\hline Shovel Test 7 & 90 & Shovel Test 30 & 90 & Shovel Test 53 & 90 \\
\hline Shovel Test 8 & 100 & Shovel Test 31 & 100 & Shovel Test 54 & 100 \\
\hline Shovel Test 9 & 90 & Shovel Test 32 & 90 & & \\
\hline Shovel Test 10 & 100 & Shovel Test 33 & 100 & Trench 4a & 150 \\
\hline Shovel Test 11 & 100 & Shovel Test 34 & 100 & Trench 5 & 150 \\
\hline Shovel Test 12 & 100 & Shovel Test 35 & 100 & Trench11 & 130 \\
\hline Shovel Test 13 & 100 & Shovel Test 36 & 100 & Trench12 & 125 \\
\hline Shovel Test 14 & 70 & Shovel Test 37 & 100 & Trench13 & 125 \\
\hline Shovel Test 15 & 100 & Shovel Test 38 & 90 & & \\
\hline Shovel Test 16 & 100 & Shovel Test 39 & 90 & Test Unit 1 & 110 \\
\hline Shovel Test 17 & 80 & Shovel Test 40 & 90 & Test Unit 2 & 110 \\
\hline Shovel Test 18 & 100 & Shovel Test 41 & 110 & Test Unit 3 & 120 \\
\hline Shovel Test 19 & 100 & Shovel Test 42 & 90 & Test Unit 4 & 110 \\
\hline Shovel Test 20 & 60 & Shovel Test 43 & 100 & Test Unit 5 & 100 \\
\hline Shovel Test 21 & 90 & Shovel Test 44 & 90 & Test Unit 6 & 130 \\
\hline Shovel Test 22 & 90 & Shovel Test 45 & 90 & Test Unit 7 & 100 \\
\hline \multirow[t]{2}{*}{ Shovel Test 23} & 110 & Shovel Test 46 & 90 & Test Unit 8 & 130 \\
\hline & & & & Test Unit 9 & 110 \\
\hline
\end{tabular}




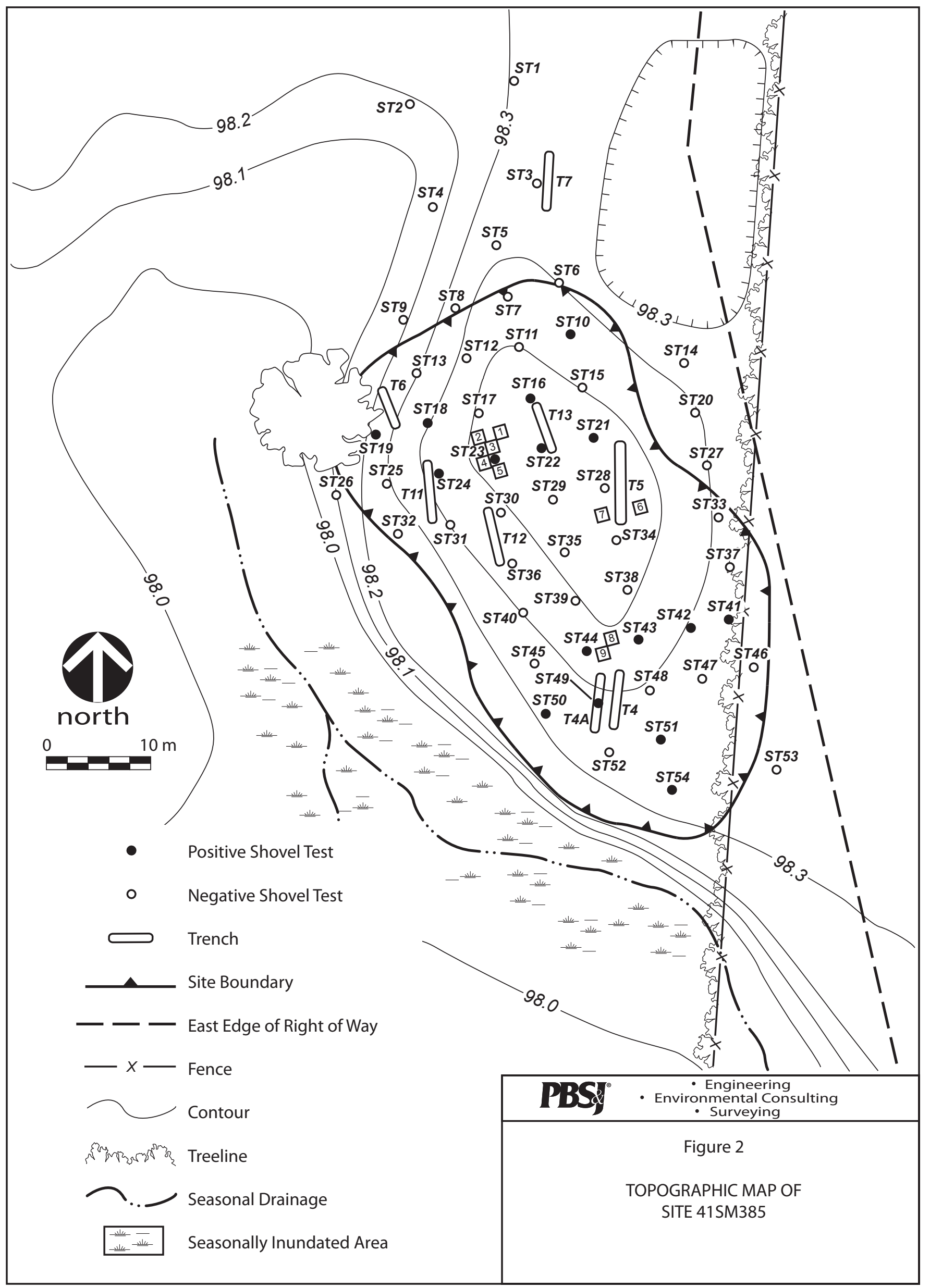

File: I:|projects\he1\clients\net rma\testing at 41 sm385\cad \figure2.ai 
Sixteen shovel tests (nos. 10, 16, 18, 19, 21-24, 41-44, 49-51, and 54) were culturally positive, yielding a total of 28 lithic debitage fragments, 2 ceramic sherds, and 1 fragment of thermally altered hematitic sandstone. Cultural material occurred between 20 and $100 \mathrm{cmbs}$ with the heaviest concentrations in levels 4 (30-40 cmbs) and 7 (60-70 cmbs) (see Appendix A).

\section{MECHANICAL EXCAVATION}

Five backhoe trenches were excavated to prospect for cultural features and to help evaluate the site's formational history. Trenches 11,12 , and 13 were oriented generally north-south and were excavated in the central part of the site that exhibited the highest artifact density to prospect for cultural features and expose a general profile of the site (see Figure 2). Two trenches excavated during the original investigation (4 and 5) were further investigated by the reopening and expansion of Trench 5 and the excavation of Trench $4 \mathrm{a}$ as close to Trench 4 as was possible, given that the original trench has slumped significantly. The five trenches were each about $65 \mathrm{~cm}$ in width and ranged from about 6 to $8 \mathrm{~m}$ in length and 125 to $150 \mathrm{~cm}$ in depth averaging about $132 \mathrm{cmbs}$ (see Table 2). No cultural features or cultural horizons were identified and no artifacts were collected during mechanical excavation of the five trenches.

Trenches typically exhibited a yellowish brown fine sandy loam Ap horizon that extended from the surface to a depth of $20 \mathrm{cmbs}$ or slightly deeper (figures 3-6). Below this surface zone, the underlying soil zones were typically lighter-colored brown or gray fine sandy loam with mottles of darker browns. Beneath a depth of about $45 \mathrm{cmbs}$, the soils also contained yellowish red mottles with hematitic and manganese inclusions as well as fine orthoquartzite gravels. Trench 13 was atypical in that it did not exhibit yellowish red mottles, hematitic and manganese inclusions, and fine orthoquartzite gravels that characterized the deeper depth of the other trenches. This may be because Trench 13 was highest in elevation and farthest from the seasonally inundated areas south and southwest of the site and may not have been subjected to as severe a seasonal inundation as the other trenches.

\section{HAND-EXCAVATED UNITS}

Nine 1-x-1-m test units were excavated by hand (see Figure 2) to sample areas of interest identified during the original site recordation and during shovel testing and trenching conducted as part of the present investigation. Hand-excavated units ranged in depth from 100 to $130 \mathrm{cmbs}$, with an average depth of $113 \mathrm{cmbs}$ (see Table 2). The cultural assemblage recovered from these units included lithic debitage and tools, ground stone fragments, ceramic sherds, and thermally altered rocks (see Appendix A). No prehistoric cultural features or stratigraphically discrete concentrations suggestive of intact cultural deposits were identified. 


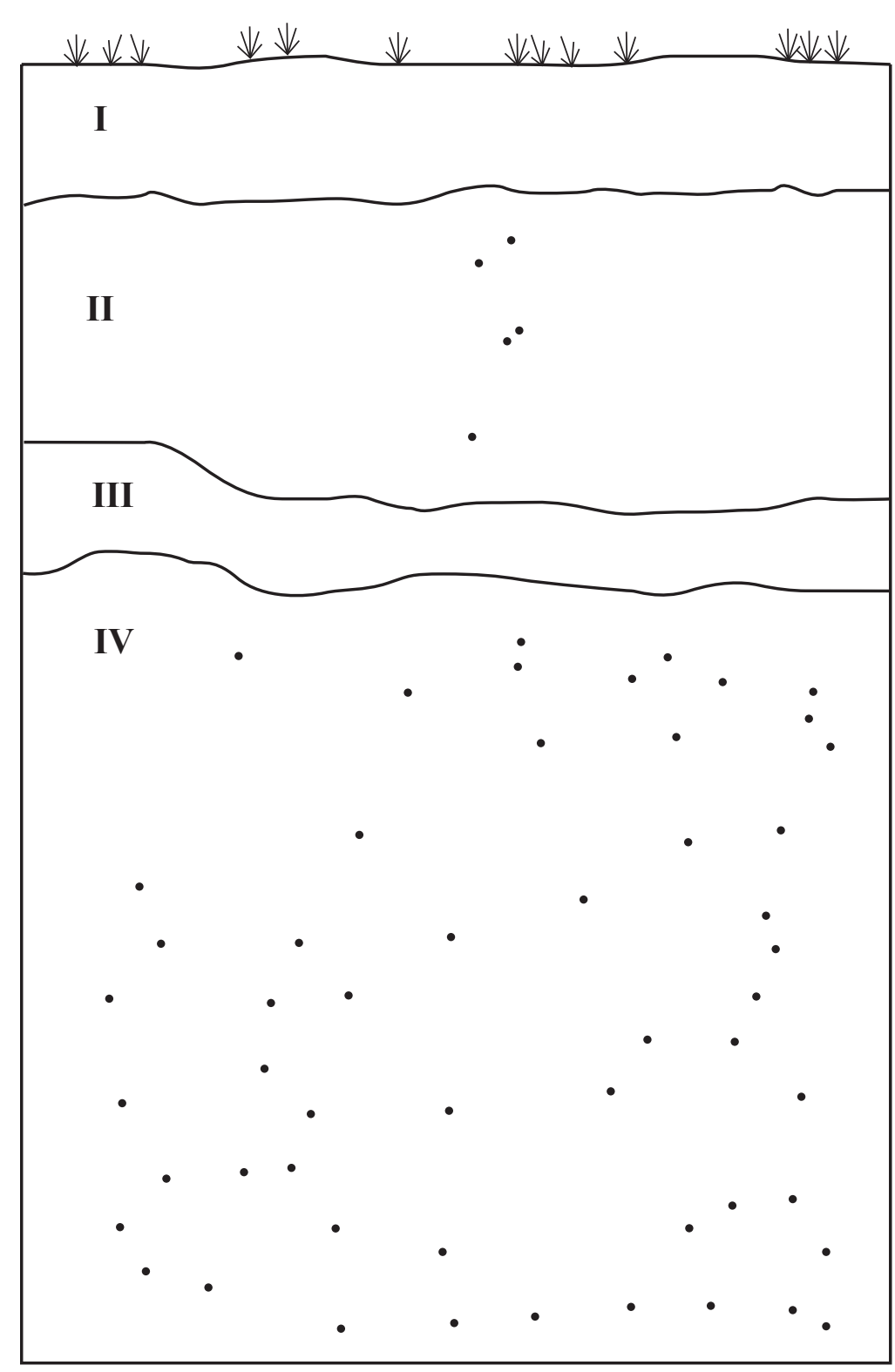

I - 10YR 4/6 yellowish brown sandy silty loam, extends from the ground surface to a maximum depth of $20 \mathrm{cmbs}$

II - 10YR 6/2 light brownish gray sandy silt mottled with 10YR 3/4 dark yellowish brown and 7.5YR 3/4 dark brown sandy silty loam, extends from the bottom of Zone II to a maximum depth of $50 \mathrm{cmbs}$

III - 7.5YR 7/1 light gray mottled with 7.5YR 5/8 strong brown loose sand with hematitic and metaquartzite inclusions, extends from the bottom of Zone III to a maximum depth of $65 \mathrm{cmbs}$

IV - 7.5YR 7/1 light gray mottled with 7.5YR 5/8 strong brown loose sand with hematitic inclusions, extends from the bottom of Zone III to an unknown depth

$\therefore$ Roots

$\Downarrow \Downarrow \Downarrow \quad$ Ground Surface

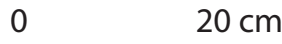

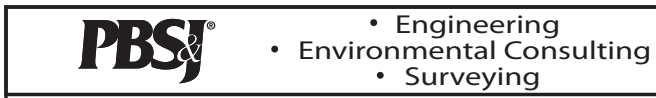

Figure 3

SITE 41SM385

BACKHOE TRENCH 4A

WEST WALL PROFILE 


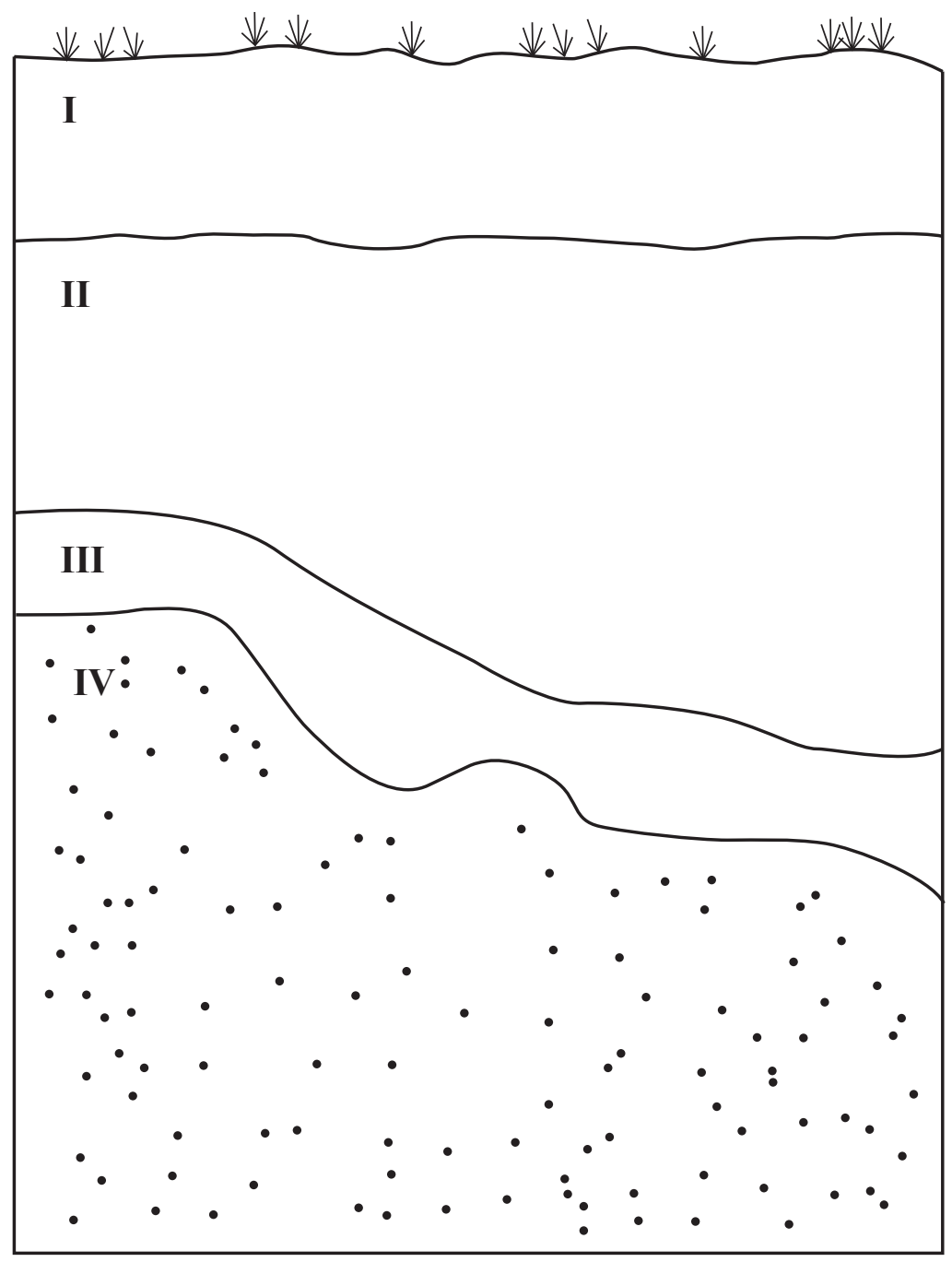

I - 10YR 4/6 dark yellowish brown sandy silty loam, loose, subangular, gradual lower boundary, dense root mat, extends from the ground surface to a maximum depth of $20 \mathrm{cmbs}$

II - 7.5YR 7/1 light gray sandy silt mottled with 7.5YR 3/4 dark brown, 10YR 5/6 yellowish brown and 7.5YR 3/4 dark brown sandy silty loam, loose, subangular, gradual lower boundary, extends from the bottom of Zone I to a maximum depth of $65 \mathrm{cmbs}$

III - 7.5YR 7/1 light gray mottled with 5YR 4/6 yellowish red and 7.5YR 5/2 very dark brown loose sand with hematitic and orthoquartzite inclusions, loose, subangular, abrupt lower boundary, extends from the bottom of Zone II to a maximum depth of $90 \mathrm{cmbs}$

IV - 7.5YR 7/1 light gray, 7.5YR 3/4 dark brown, and 5YR 4/6 yellowish red sand, loose subangular, unknown lower boundary

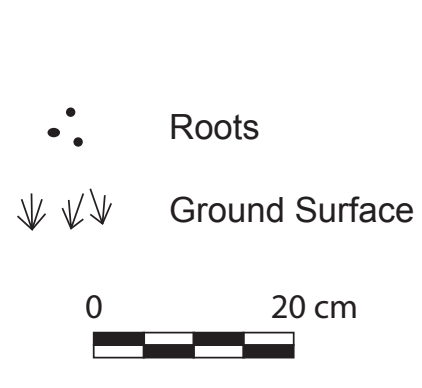

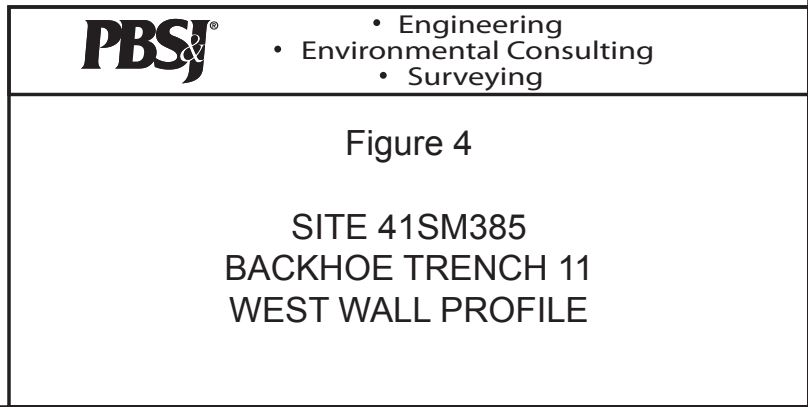




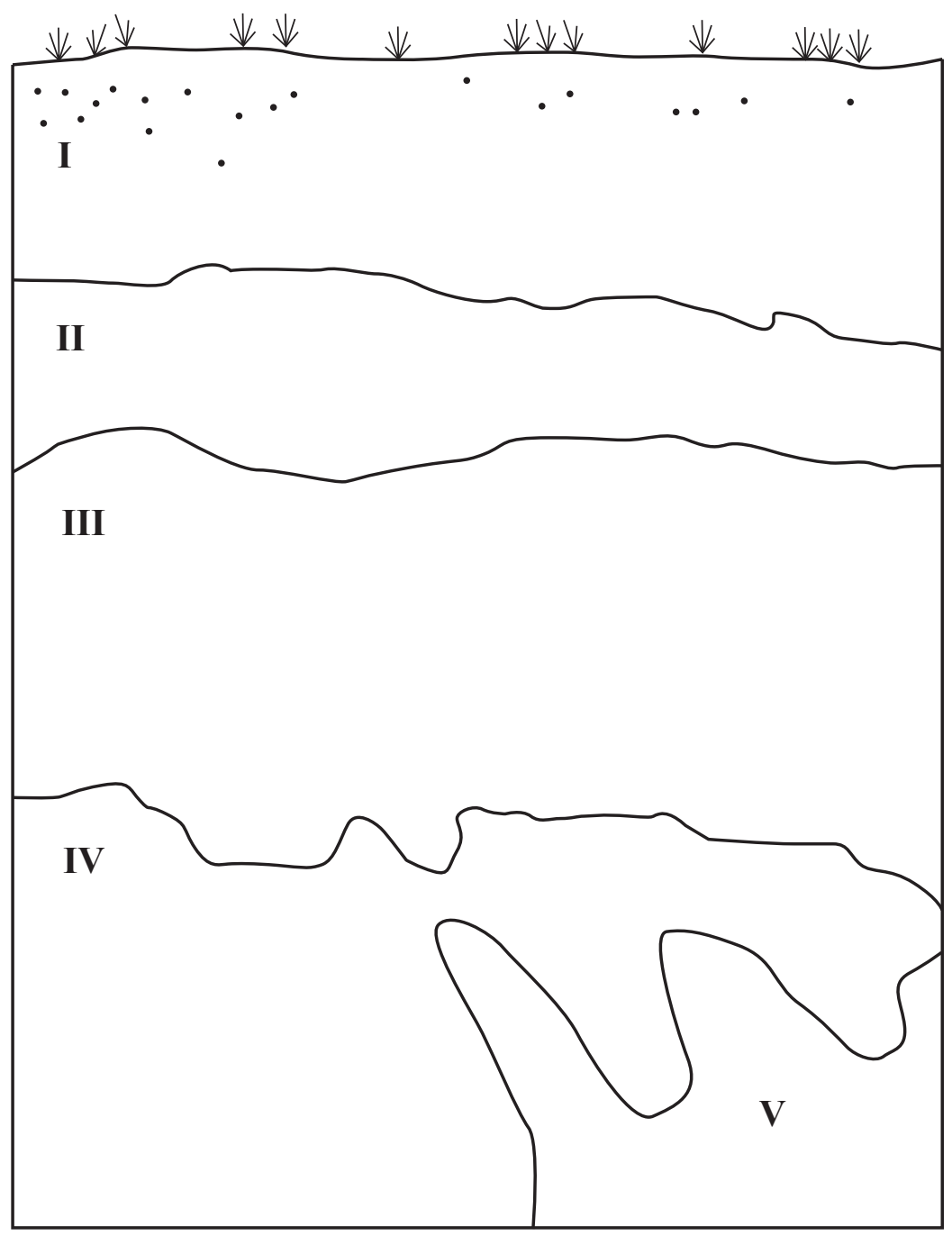

I - 10YR 5/6 yellowish brown fine sandy loam, loose, subangular, gradual lower boundary, dense root mat, extends from the ground surface to a maximum depth of $35 \mathrm{cmbs}$

II - 10YR 6/4 light yellow-brown silty loam, loose, subangular, gradual lower boundary, few roots, extends from the bottom of Zone I to a maximum depth of $50 \mathrm{cmbs}$

III - 7.5YR 4/6 strong brown sandy loam mottled with 10YR 6/4 light yellow brown sandy loam and 2.5YR 4/8 red with 10YR 2/1 black manganese inclusions, loose, subangular, gradual lower boundary, extends from the bottom of Zone II to a maximum depth of $90 \mathrm{cmbs}$

IV - 7.5YR 5/6 yellow brown, 5YR 3/4 dark brown, and 5YR 4/6 yellowish red sand, loose, subangular, unknown lower boundary

$\mathrm{V}$ - 10YR 6/3 pale brown loose sand, no roots, unknown lower boundary

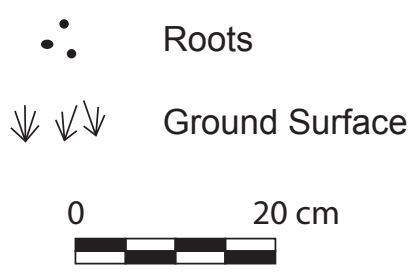

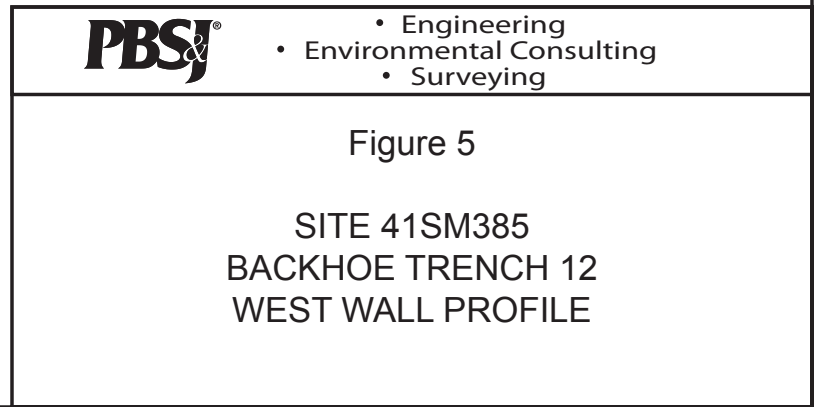

File: I:|projects\he1\clients\net ram\testing at $41 \mathrm{sm} 385 \backslash \mathrm{cad} \backslash$ figure5.ai 


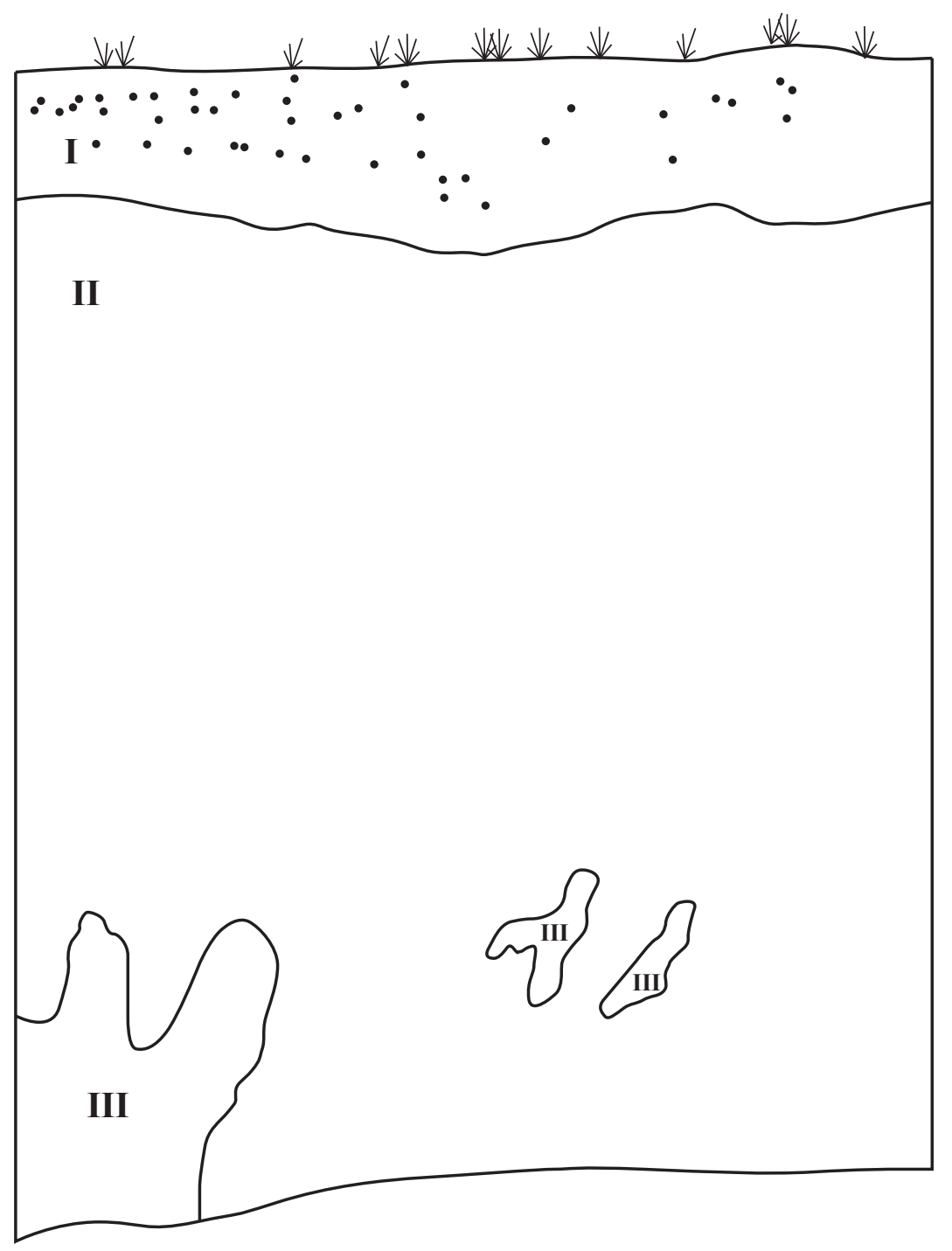

I - 10YR 4/6 dark yellow-brown sandy silty loam, loose, subangular, gradual lower boundary, dense root mat, extends from the ground surface to a maximum depth of $20 \mathrm{cmbs}$

II - 7.5YR 4/6 strong brown and 10YR 6/4 light yellow-brown compact fine sandy loam extending to an unknown depth

III - 10YR 6/3 pale brown loose sand extending to an unknow depth

$\therefore$ Roots

$\Downarrow \Downarrow \Downarrow \quad$ Ground Surface

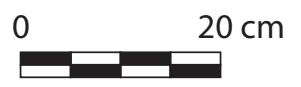

\begin{tabular}{|c|}
\hline PBS\& \\
\hline $\begin{array}{c}\cdot \text { Engineering } \\
\text { - Enmental Consulting } \\
\text { Surveying }\end{array}$ \\
Figure 6 \\
SITE 41SM385 \\
BACKHOE TRENCH 13 \\
WEST WALL PROFILE \\
\end{tabular}

File: I:|projects\he1\clients\net ram\testing at 41 sm385\cad \figure6.ai 
During controlled hand excavation, 766 artifacts were recovered from the ground surface to a depth of $130 \mathrm{~cm}$. The bulk of the artifacts (89.5 percent) were recovered between 10 and $80 \mathrm{~cm}$ in depth. Artifacts largely represent a roughly equivalent vertical distribution within this range; however, the heaviest density of material was from between 20 and $40 \mathrm{~cm}$ in depth where 34.5 percent of the artifacts were recovered.

Test Units 1-5. Units 1-5 were excavated in order to investigate a high artifact density area in the northwest-central part of the site that was identified during shovel testing. Units 1 and 2 were excavated to a depth of $110 \mathrm{cmbs}$, and units 3-5 were excavated to a depth of $120 \mathrm{cmbs}$. All five units exhibited a fine sandy loam that manifested manganese and hematite inclusions at lower depths (figures 7-10).

The vertical distribution of artifacts was typically a homogenous distribution between about 10 and $80 \mathrm{cmbs}$ with lower densities above and below this zone (Table 3). Unit 1 yielded 90 pieces of nondiagnostic lithic debitage, 3 lithic tools including a Gary dart point, and 3 pieces of thermally altered hematitic sandstone. Unit 2 contained 93 pieces of nondiagnostic lithic debitage, 1 lithic tool fragment, and 2 pieces of thermally altered hematitic sandstone. Unit 3 yielded 104 pieces of nondiagnostic lithic debitage, 1 lithic tool, 7 prehistoric ceramic sherds, and 1 thermally altered rock. Unit 4 contained 107 pieces of nondiagnostic lithic debitage, 4 lithic tools including 1 abrader and 1 unidentified dart point fragment, 1 prehistoric ceramic sherd, and 1 piece of thermally altered hematitic sandstone. Unit 5 contained 188 pieces of nondiagnostic lithic debitage, 2 lithic tools including 1 abrader and a Gary dart point, and 1 piece of thermally altered hematitic sandstone.

Test Units 6 and 7. These two units were excavated to further investigate an area of the site found to contain cultural material during the site's original Phase I recordation. Unit 6 was excavated to a depth of $130 \mathrm{cmbs}$ and exhibited compact to loose, sandy loam over loose sand with hematite and manganese inclusions, underlain by a zone of loose sandy loam. Unit 7 was excavated to a depth of $100 \mathrm{cmbs}$ and exhibited compact to loose, sandy loam over loose sandy loam with manganese and hematite inclusions but was terminated prior to encountering the lower stratum of loose sandy loam (Figure 11). The heaviest vertical distribution of artifacts was between about 20 and $70 \mathrm{cmbs}$ in Unit 6 and 10 and $100 \mathrm{cmbs}$ in Unit 7 (see Table 3). Unit 6 contained 19 pieces of nondiagnostic lithic debitage and 1 Gary type dart point. Unit 7 contained 21 pieces of nondiagnostic lithic debitage, 4 prehistoric ceramic sherds, and 1 piece of thermally altered hematitic sandstone.

Test Units 8 and 9. These two 1-x-1-m units were excavated to investigate an area of relatively high artifact density in the southern portion of the site identified during shovel testing. Because a relatively large number of thermally altered rock fragments was recovered in unit 8, unit 9 was placed immediately southwest to prospect for an intact cultural feature. Unit 8 extended to $130 \mathrm{cmbs}$ and Unit 9 extended to a depth of $110 \mathrm{cmbs}$. Their stratigraphy was similar to Unit 6, 


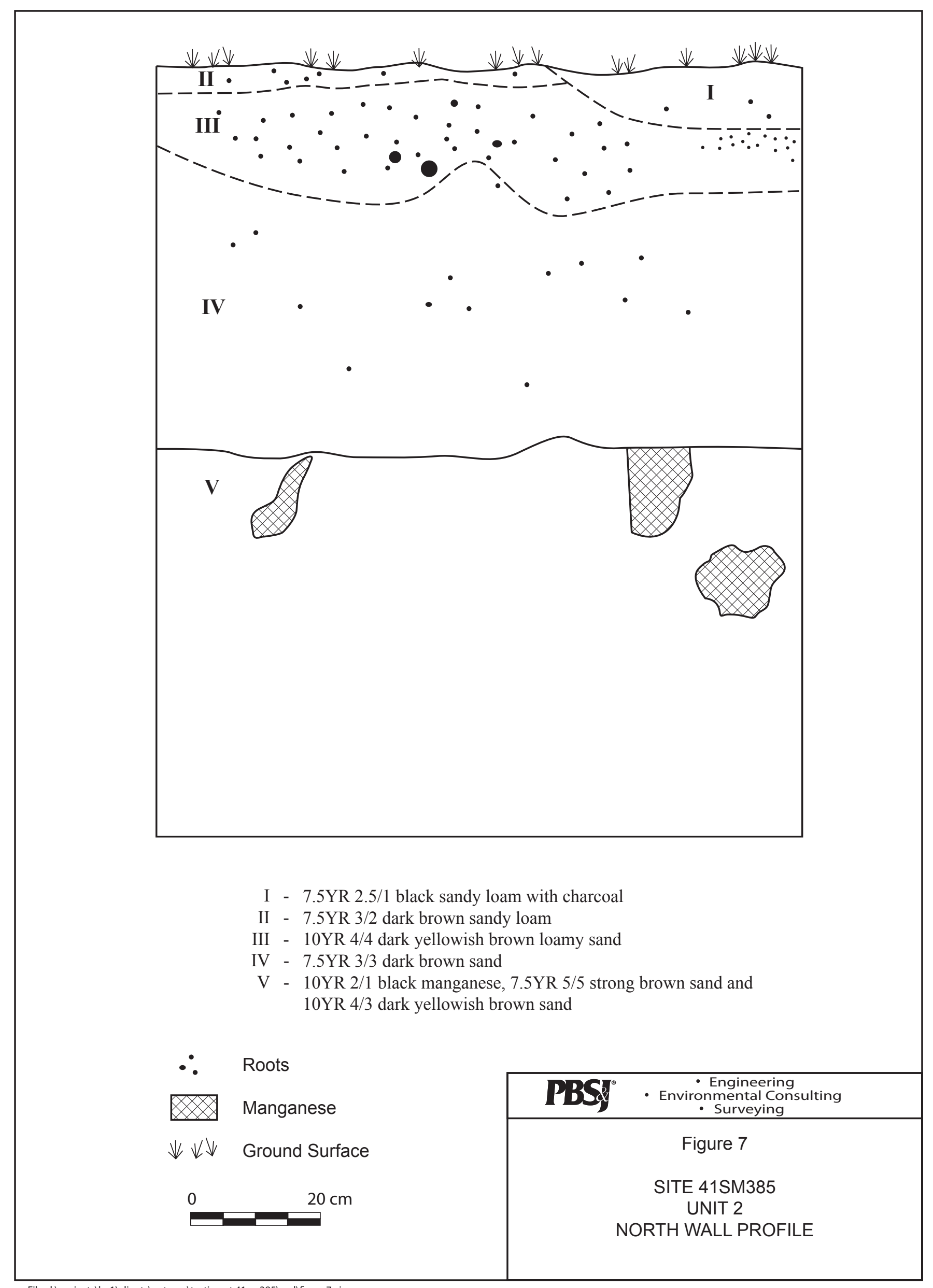

File: I:|projects\he1\clients\net ram\testing at 41 sm385\cad \figure7.ai 


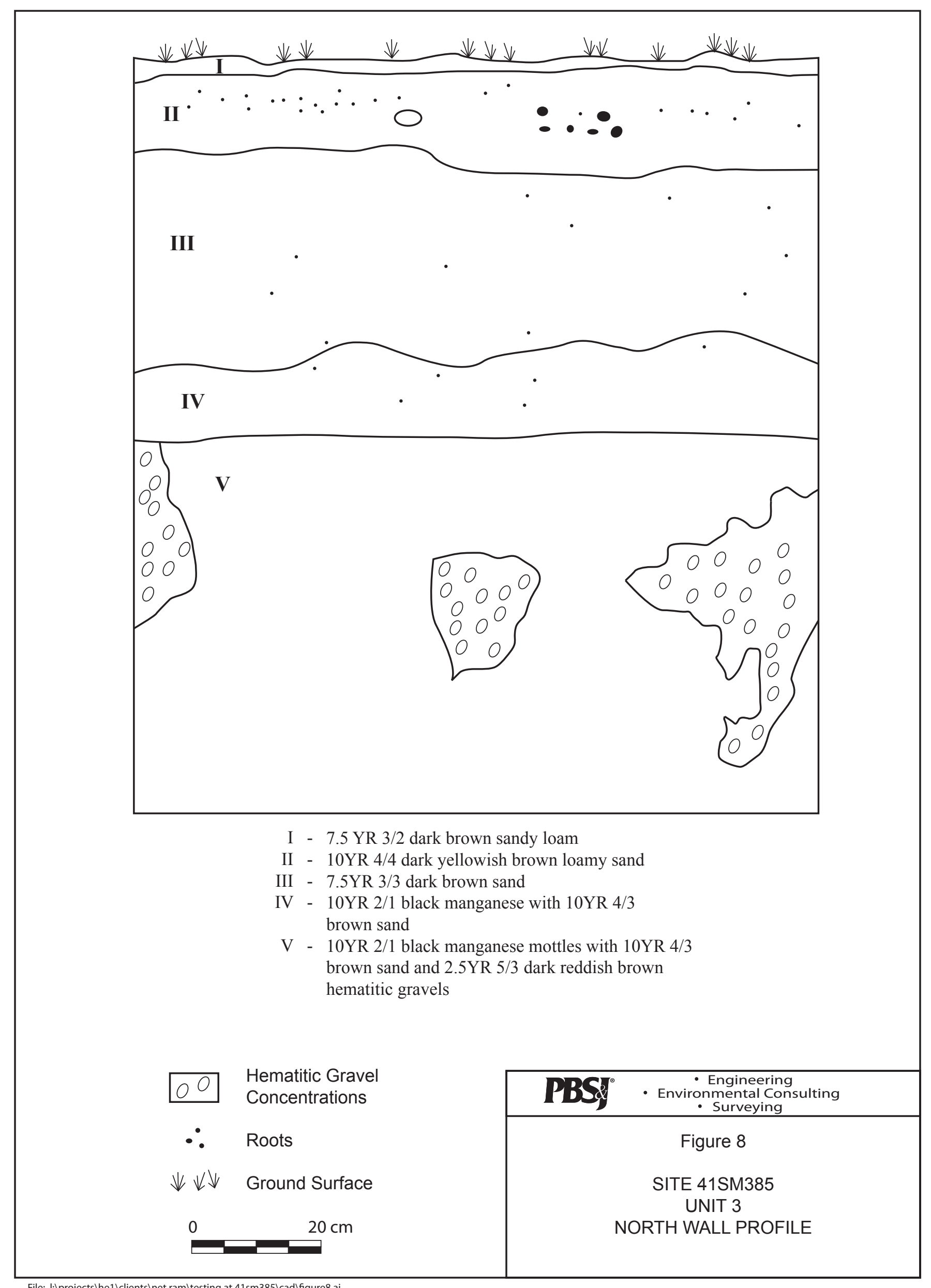

File: I:|projects \he1 $\backslash$ clients \net ram \testing at $41 \mathrm{sm} 385 \backslash \mathrm{cad} \backslash$ figure8.ai 


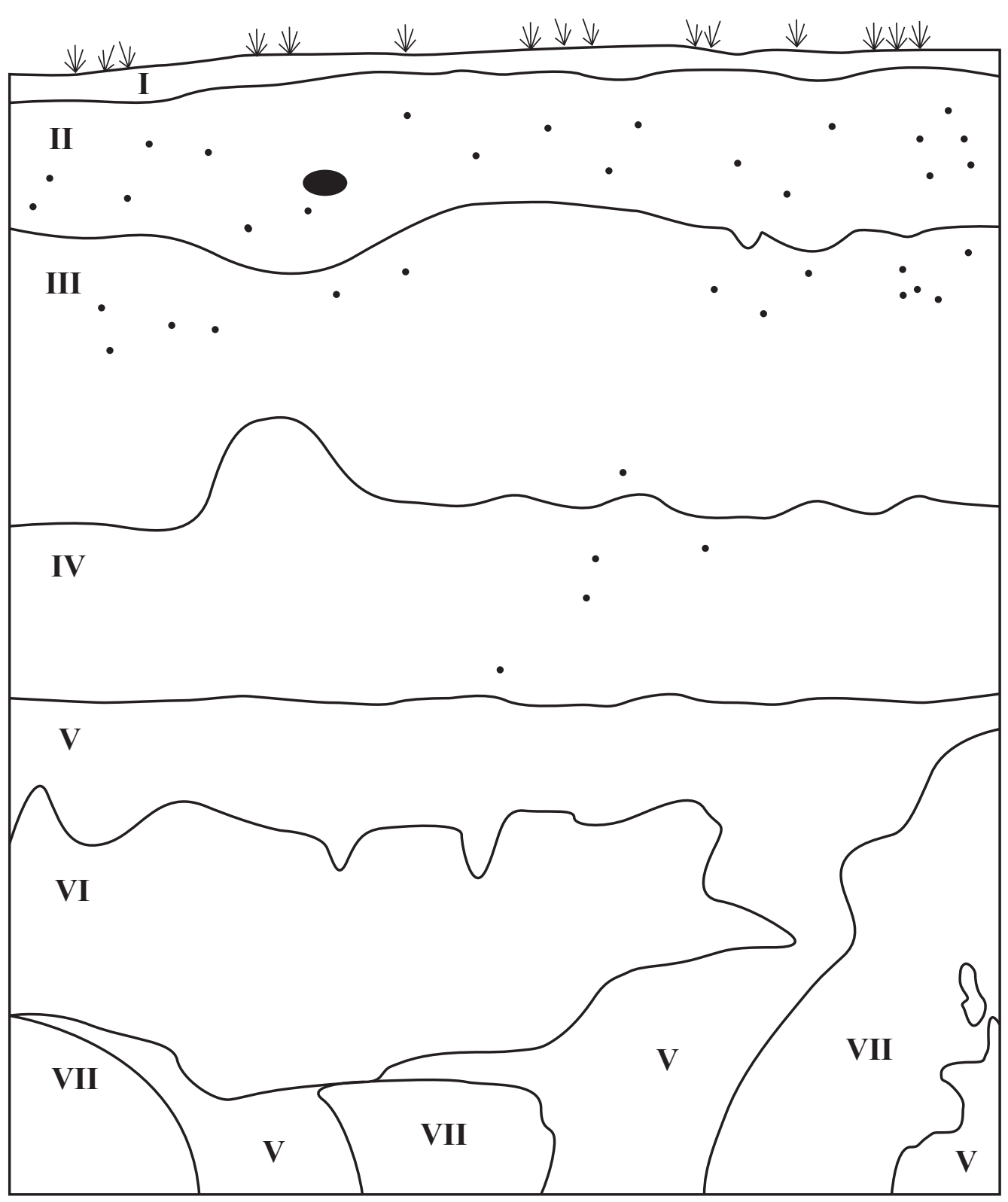

I - 7.5YR 3/2 dark brown sandy loam

II - 10YR 4/4 dark yellowish brown loamy sand

III - 7.5YR 3/3 dark brown sand

IV - 10YR 2/1 black manganese mottles with 10YR 4/3 brown sand and 2.5 YR $5 / 3$ dark reddish brown hematitic gravels

$\mathrm{V}$ - 7/5YR 4/6 strong brown and 10YR 6/3 pale brown sandy loam with some hematitic gravels

VI - 7/5YR 4/6 strong brown and 10YR 6/3 pale brown sandy loam with over 50 percent hematitic gravels

VII - 10YR 6/3 pale brown sandy loam

$\therefore \quad$ Roots

$\Downarrow \Downarrow \Downarrow \quad$ Ground Surface

0

$20 \mathrm{~cm}$

\begin{tabular}{|c|c|}
\hline PBS: Engineering \\
\hline Environmental Consulting \\
- Surveying
\end{tabular}

Figure 9

SITE 41SM385

UNIT 4

NORTH WALL PROFILE 


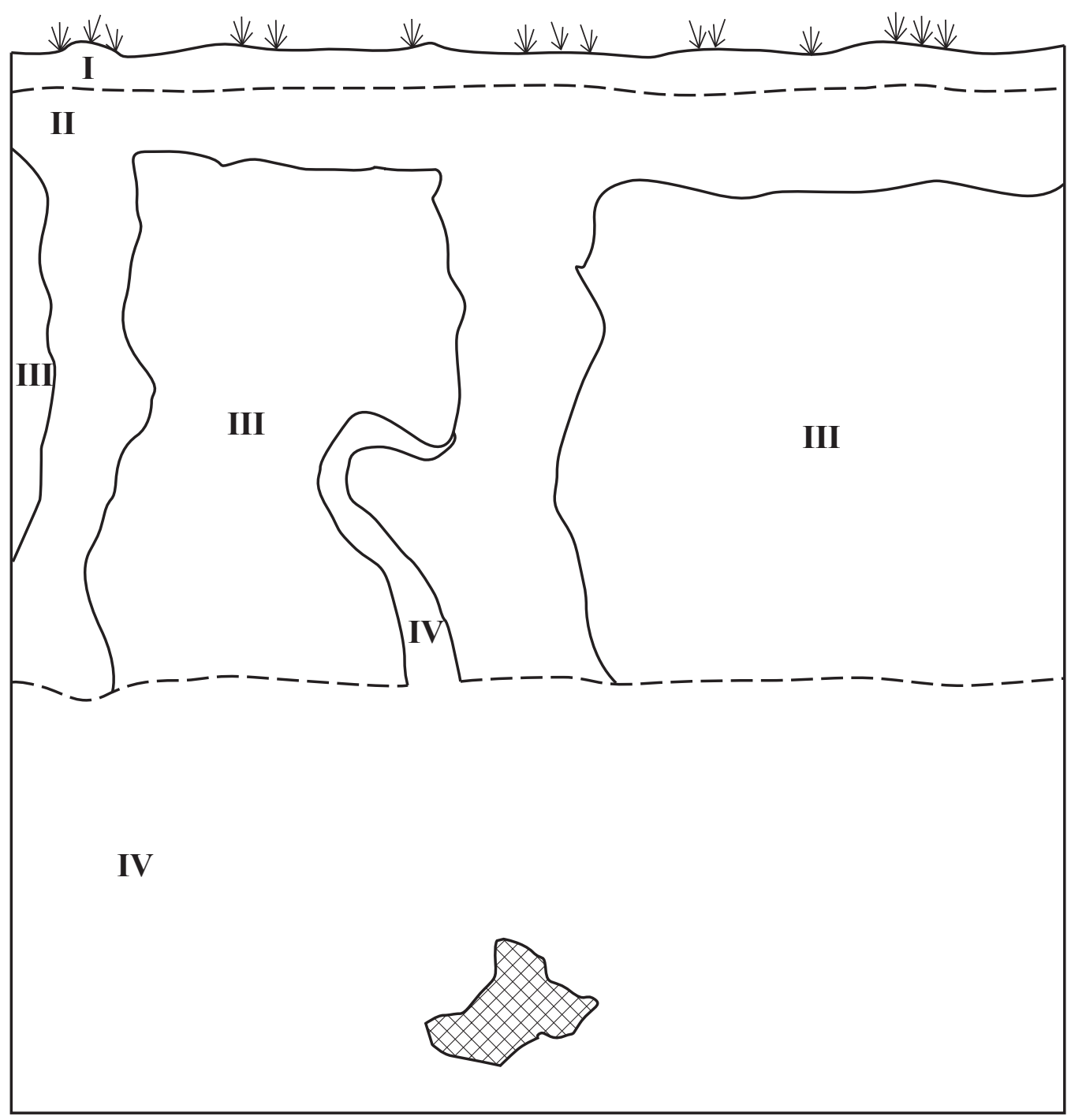

I - 7.5YR 3/2 dark brown sandy loam

II - 10YR 4/4 dark yellowish brown loamy sand

III - 7.5YR 3/3 dark brown sand

IV - 7.5YR 4/6 strong brown sand and 10YR 6/3 pale brown sandy loam with 10YR 2/1 black manganese mottles

$\therefore \quad$ Roots

$\Downarrow \Downarrow \Downarrow \quad$ Ground Surface

Decomposing hematitic gravels

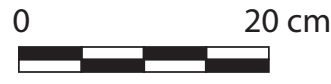

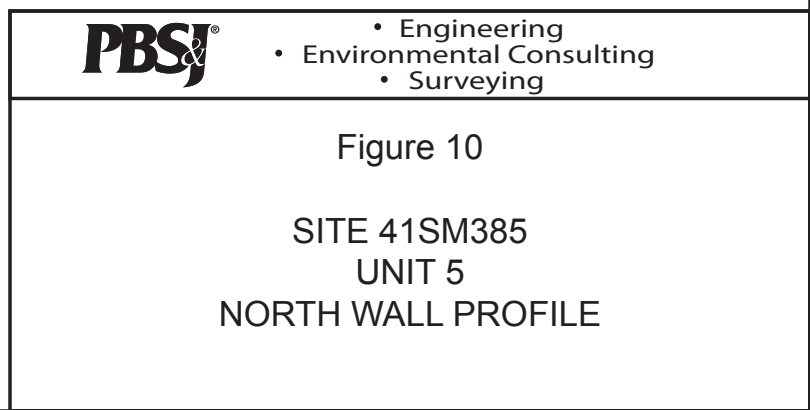

File: I::projects\he1\clients\net ram\testing at $41 \mathrm{sm} 385 \backslash$ cad $\backslash$ figure10.ai 


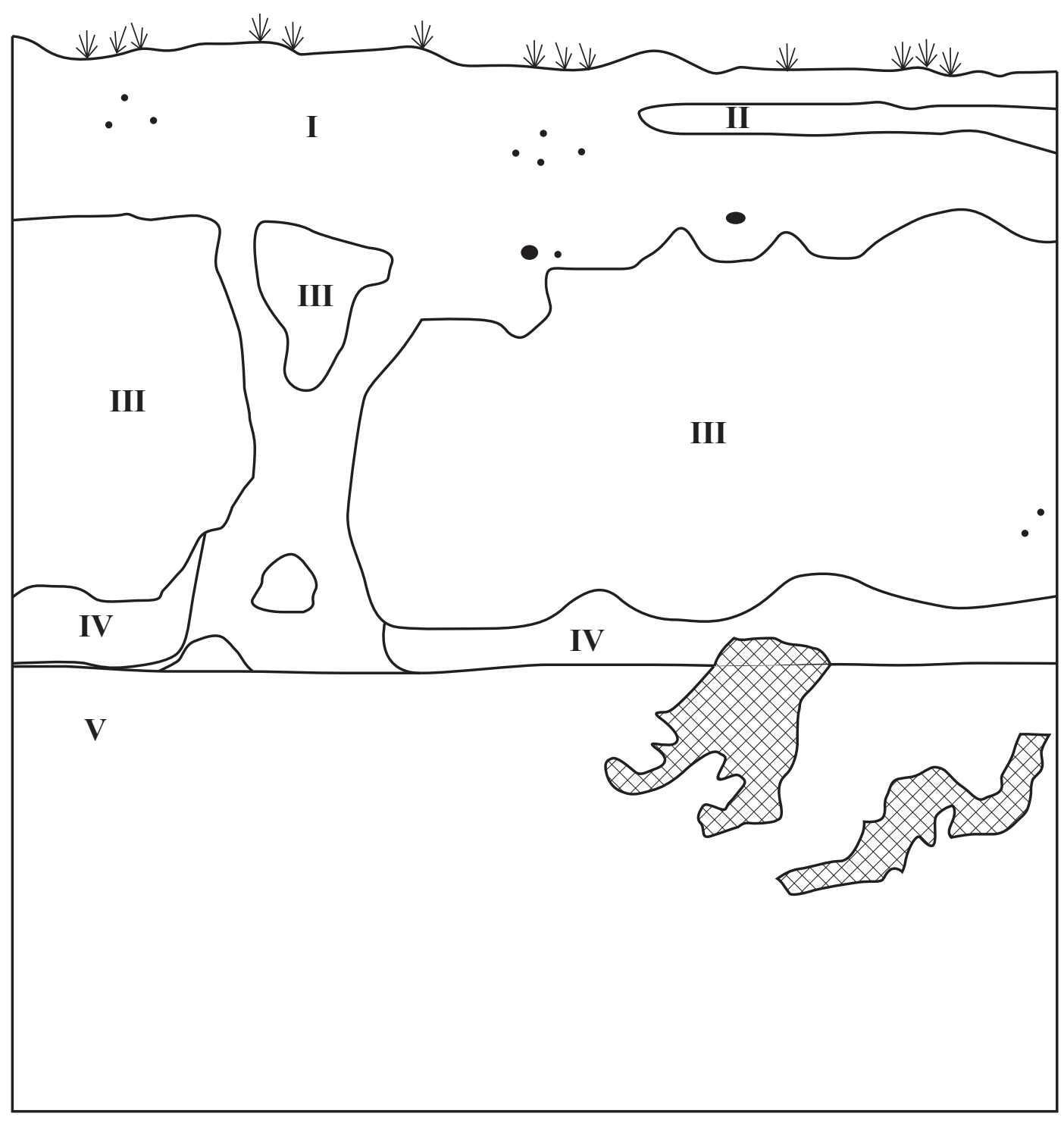

I - 10YR 6/3 pale brown loamy sand

II - 7.5YR 3/2 dark brown loamy sand

III - 7.5YR 4/4 dark brown sand

IV - 10YR 2/1 black manganese with 10YR 4/3 brown sand

$\mathrm{V}$ - $7.5 \mathrm{YR} 4 / 6$ and 7/5YR 5/6 strong brown sandy loam mottled with 2.5YR 2.5/4 dark reddish brown hematitic nodules

$\therefore \quad$ Roots

$\Downarrow \Downarrow \Downarrow \quad$ Ground Surface

Manganese

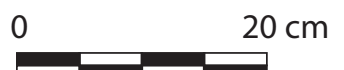
PBS ${ }^{\bullet} \cdot \begin{gathered}\text { Engineering } \\ \text { - Environmental Consulting } \\ \text { Surveying }\end{gathered}$

Figure 11

SITE 41SM385

UNIT 7

NORTH WALL PROFILE 
Table 3: Cultural Material from Test Units

\begin{tabular}{|c|c|c|c|c|c|c|c|c|c|}
\hline Unit & Level & $\begin{array}{l}\frac{\tilde{U}}{E} \\
\frac{1}{0} \\
\frac{U}{U}\end{array}$ & 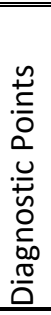 & 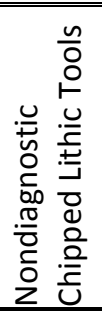 & 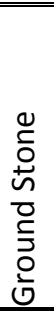 & 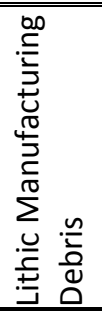 & 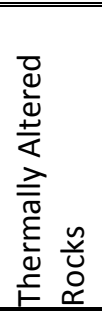 & 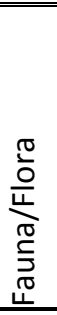 & 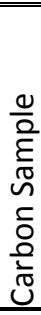 \\
\hline \multicolumn{10}{|c|}{ Test Unit 1-5 Group } \\
\hline \multirow[t]{11}{*}{1} & 1 & 0 & 0 & 0 & 0 & 2 & 0 & 0 & 0 \\
\hline & 2 & 0 & 0 & 1 & 0 & 23 & 0 & 0 & 0 \\
\hline & 3 & 0 & 0 & 0 & 0 & 11 & 0 & 0 & 0 \\
\hline & 4 & 0 & 0 & 1 & 0 & 9 & 0 & 0 & 0 \\
\hline & 5 & 0 & 0 & 0 & 0 & 12 & 1 & 0 & 0 \\
\hline & 6 & 0 & 0 & 0 & 0 & 9 & 2 & 0 & 0 \\
\hline & 7 & 0 & 0 & 0 & 0 & 6 & 0 & 0 & 0 \\
\hline & 8 & 0 & 0 & 0 & 0 & 12 & 0 & 0 & 1 \\
\hline & 9 & 0 & 1 & 0 & 0 & 5 & 0 & 0 & 0 \\
\hline & 10 & 0 & 0 & 0 & 0 & 1 & 0 & 0 & 0 \\
\hline & 11 & 0 & 0 & 0 & 0 & 0 & 0 & 0 & 0 \\
\hline \multicolumn{2}{|c|}{ Unit Subtotal } & 0 & 1 & 2 & 0 & 90 & 3 & 0 & 1 \\
\hline \multirow[t]{11}{*}{2} & 1 & 0 & 0 & 0 & 0 & 0 & 0 & 0 & 0 \\
\hline & 2 & 0 & 0 & 0 & 0 & 3 & 0 & 0 & 0 \\
\hline & 3 & 0 & 0 & 1 & 0 & 24 & 0 & 0 & 0 \\
\hline & 4 & 0 & 0 & 0 & 0 & 17 & 1 & 0 & 0 \\
\hline & 5 & 0 & 0 & 0 & 0 & 8 & 1 & 0 & 0 \\
\hline & 6 & 0 & 0 & 0 & 0 & 11 & 0 & 0 & 0 \\
\hline & 7 & 0 & 0 & 0 & 0 & 13 & 0 & 0 & 0 \\
\hline & 8 & 0 & 0 & 0 & 0 & 10 & 0 & 0 & 0 \\
\hline & 9 & 0 & 0 & 0 & 0 & 5 & 0 & 0 & 1 \\
\hline & 10 & 0 & 0 & 0 & 0 & 2 & 0 & 0 & 0 \\
\hline & 11 & 0 & 0 & 0 & 0 & 0 & 0 & 0 & 0 \\
\hline \multicolumn{2}{|c|}{ Unit Subtotal } & 0 & 0 & 1 & 0 & 93 & 2 & 0 & 1 \\
\hline
\end{tabular}


Table 3 (Cont'd)

\begin{tabular}{|c|c|c|c|c|c|c|c|c|c|}
\hline Unit & Level & $\begin{array}{l}\stackrel{\widetilde{U}}{\frac{\tilde{E}}{\sigma}} \\
\frac{\tilde{U}}{\tilde{U}} \\
\end{array}$ & 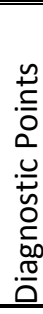 & 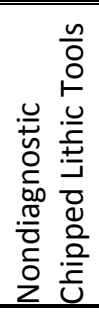 & 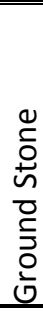 & 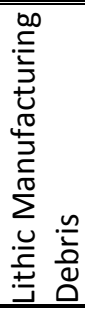 & 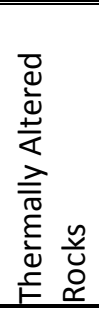 & 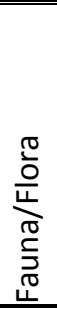 & 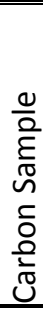 \\
\hline \multirow[t]{12}{*}{3} & 1 & 7 & 0 & 0 & 0 & 0 & 0 & 0 & 0 \\
\hline & 2 & 0 & 0 & 0 & 0 & 10 & 0 & 0 & 0 \\
\hline & 3 & 0 & 0 & 0 & 0 & 14 & 0 & 0 & 0 \\
\hline & 4 & 0 & 0 & 0 & 0 & 19 & 0 & 0 & 0 \\
\hline & 5 & 0 & 0 & 0 & 0 & 6 & 0 & 0 & 0 \\
\hline & 6 & 0 & 0 & 0 & 0 & 22 & 1 & 0 & 0 \\
\hline & 7 & 0 & 0 & 0 & 0 & 17 & 0 & 0 & 0 \\
\hline & 8 & 0 & 0 & 0 & 0 & 11 & 0 & 0 & 0 \\
\hline & 9 & 0 & 0 & 1 & 0 & 1 & 0 & 0 & 0 \\
\hline & 10 & 0 & 0 & 0 & 0 & 3 & 0 & 0 & 0 \\
\hline & 11 & 0 & 0 & 0 & 0 & 1 & 0 & 0 & 0 \\
\hline & 12 & 0 & 0 & 0 & 0 & 0 & 0 & 0 & 0 \\
\hline \multicolumn{2}{|c|}{ Unit Subtotal } & 7 & 0 & 1 & 0 & 104 & 1 & 0 & 0 \\
\hline \multirow[t]{12}{*}{4} & 1 & 0 & 0 & 0 & 0 & 1 & 0 & 0 & 0 \\
\hline & 2 & 0 & 0 & 0 & 1 & 2 & 0 & 0 & 0 \\
\hline & 3 & 0 & 0 & 0 & 0 & 25 & 0 & 0 & 0 \\
\hline & 4 & 0 & 0 & 0 & 0 & 14 & 1 & 0 & 0 \\
\hline & 5 & 1 & 0 & 0 & 0 & 17 & 0 & 0 & 0 \\
\hline & 6 & 0 & 1 & 0 & 0 & 15 & 0 & 0 & 0 \\
\hline & 7 & 0 & 0 & 1 & 0 & 16 & 0 & 0 & 0 \\
\hline & 8 & 0 & 0 & 0 & 0 & 15 & 0 & 0 & 0 \\
\hline & 9 & 0 & 0 & 0 & 0 & 2 & 0 & 0 & 0 \\
\hline & 10 & 0 & 0 & 0 & 0 & 0 & 0 & 0 & 0 \\
\hline & 11 & 0 & 0 & 1 & 0 & 0 & 0 & 0 & 0 \\
\hline & 12 & 0 & 0 & 0 & 0 & 0 & 0 & 0 & 0 \\
\hline \multicolumn{2}{|c|}{ Unit Subtotal } & 1 & 1 & 2 & 1 & 107 & 1 & 0 & 0 \\
\hline
\end{tabular}


Table 3 (Cont'd)

\begin{tabular}{|c|c|c|c|c|c|c|c|c|c|}
\hline Unit & Level & $\begin{array}{l}\frac{U}{E} \\
\frac{\pi}{\pi} \\
\stackrel{U}{U}\end{array}$ & 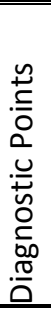 & 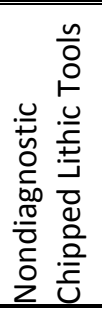 & 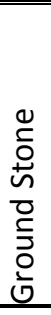 & 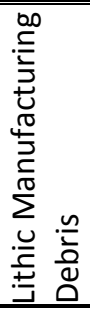 & 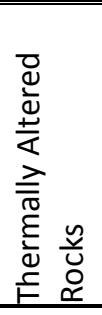 & 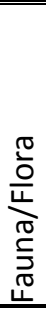 & 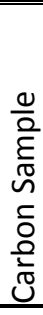 \\
\hline \multirow[t]{12}{*}{5} & 1 & 0 & 0 & 0 & 0 & 11 & 0 & 0 & 0 \\
\hline & 2 & 0 & 0 & 0 & 0 & 19 & 0 & 0 & 0 \\
\hline & 3 & 0 & 0 & 0 & 1 & 42 & 0 & 0 & 0 \\
\hline & 4 & 0 & 0 & 0 & 0 & 56 & 1 & 0 & 0 \\
\hline & 5 & 0 & 0 & 0 & 0 & 30 & 0 & 0 & 0 \\
\hline & 6 & 0 & 0 & 0 & 0 & 17 & 0 & 0 & 0 \\
\hline & 7 & 0 & 1 & 0 & 0 & 8 & 0 & 0 & 0 \\
\hline & 8 & 0 & 0 & 0 & 0 & 5 & 0 & 0 & 0 \\
\hline & 9 & 0 & 0 & 0 & 0 & 0 & 0 & 0 & 0 \\
\hline & 10 & 0 & 0 & 0 & 0 & 0 & 0 & 0 & 0 \\
\hline & 11 & 0 & 0 & 0 & 0 & 0 & 0 & 0 & 0 \\
\hline & 12 & 0 & 0 & 0 & 0 & 0 & 0 & 0 & 0 \\
\hline \multicolumn{2}{|c|}{ Unit Subtotal } & 0 & 1 & 0 & 1 & 188 & 1 & 0 & 0 \\
\hline \multicolumn{2}{|c|}{ Group Subtotal } & 8 & 3 & 6 & 2 & 582 & 8 & 0 & 2 \\
\hline
\end{tabular}

Test Unit 6-7 Group

\begin{tabular}{|c|c|c|c|c|c|c|c|c|c|}
\hline \multirow[t]{13}{*}{6} & 1 & 0 & 0 & 0 & 0 & 0 & 0 & 0 & 0 \\
\hline & 2 & 0 & 0 & 0 & 0 & 5 & 0 & 0 & 0 \\
\hline & 3 & 0 & 0 & 0 & 0 & 4 & 0 & 0 & 0 \\
\hline & 4 & 0 & 0 & 0 & 0 & 0 & 0 & 0 & 0 \\
\hline & 5 & 0 & 0 & 0 & 0 & 0 & 0 & 0 & 0 \\
\hline & 6 & 0 & 1 & 0 & 0 & 0 & 0 & 0 & 0 \\
\hline & 7 & 0 & 0 & 0 & 0 & 3 & 0 & 0 & 0 \\
\hline & 8 & 0 & 0 & 0 & 0 & 2 & 0 & 0 & 0 \\
\hline & 9 & 0 & 0 & 0 & 0 & 0 & 0 & 0 & 0 \\
\hline & 10 & 0 & 0 & 0 & 0 & 3 & 0 & 0 & 0 \\
\hline & 11 & 0 & 0 & 0 & 0 & 1 & 0 & 0 & 0 \\
\hline & 12 & 0 & 0 & 0 & 0 & 1 & 0 & 0 & 0 \\
\hline & 13 & 0 & 0 & 0 & 0 & 0 & 0 & 0 & 0 \\
\hline \multicolumn{2}{|c|}{ Unit Subtotal } & 0 & 1 & 0 & 0 & 19 & 0 & 0 & 0 \\
\hline
\end{tabular}


Table 3 (Cont'd)

\begin{tabular}{|c|c|c|c|c|c|c|c|c|c|}
\hline Unit & Level & 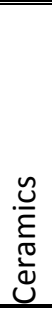 & 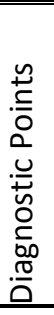 & 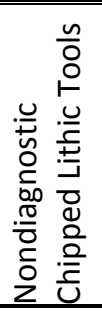 & 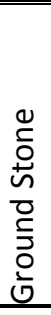 & 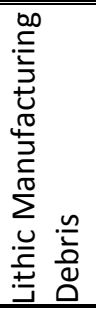 & 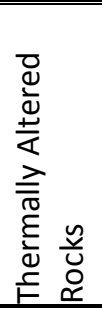 & 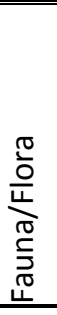 & 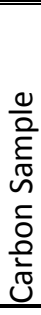 \\
\hline \multirow[t]{10}{*}{7} & 1 & 0 & 0 & 0 & 0 & 0 & 0 & 0 & 0 \\
\hline & 2 & 0 & 0 & 0 & 0 & 0 & 0 & 0 & 0 \\
\hline & 3 & 2 & 0 & 0 & 0 & 7 & 0 & 0 & 0 \\
\hline & 4 & 0 & 0 & 0 & 0 & 5 & 0 & 0 & 0 \\
\hline & 5 & 0 & 0 & 0 & 0 & 2 & 0 & 0 & 0 \\
\hline & 6 & 2 & 0 & 0 & 0 & 2 & 1 & 0 & 0 \\
\hline & 7 & 0 & 0 & 0 & 0 & 4 & 0 & 0 & 0 \\
\hline & 8 & 0 & 0 & 0 & 0 & 1 & 0 & 0 & 0 \\
\hline & 9 & 0 & 0 & 0 & 0 & 0 & 0 & 0 & 0 \\
\hline & 10 & 0 & 0 & 0 & 0 & 0 & 0 & 0 & 0 \\
\hline \multicolumn{2}{|c|}{ Unit Subtotal } & 4 & 0 & 0 & 0 & 21 & 1 & 0 & 0 \\
\hline \multicolumn{2}{|c|}{ Group Totals } & 4 & 1 & 0 & 0 & 40 & 1 & 0 & 0 \\
\hline \multicolumn{10}{|c|}{ Test Unit 8-9 Group } \\
\hline \multirow[t]{13}{*}{8} & 1 & 0 & 0 & 0 & 0 & 2 & 0 & 0 & 0 \\
\hline & 2 & 0 & 0 & 0 & 0 & 7 & 1 & 0 & 0 \\
\hline & 3 & 0 & 0 & 0 & 0 & 7 & 1 & 0 & 0 \\
\hline & 4 & 0 & 0 & 0 & 0 & 7 & 0 & 0 & 0 \\
\hline & 5 & 0 & 0 & 0 & 0 & 7 & 2 & 0 & 0 \\
\hline & 6 & 0 & 0 & 0 & 0 & 3 & 0 & 0 & 0 \\
\hline & 7 & 2 & 0 & 0 & 0 & 7 & 0 & 0 & 0 \\
\hline & 8 & 1 & 0 & 0 & 0 & 5 & 0 & 0 & 0 \\
\hline & 9 & 1 & 0 & 0 & 0 & 5 & 0 & 0 & 0 \\
\hline & 10 & 0 & 0 & 0 & 0 & 1 & 0 & 0 & 0 \\
\hline & 11 & 0 & 0 & 0 & 0 & 5 & 0 & 0 & 0 \\
\hline & 12 & 0 & 0 & 0 & 0 & 6 & 0 & 0 & 0 \\
\hline & 13 & 0 & 0 & 0 & 0 & 0 & 0 & 0 & 0 \\
\hline \multicolumn{2}{|c|}{ Unit Subtotal } & 4 & 0 & 0 & 0 & 62 & 4 & 0 & 0 \\
\hline
\end{tabular}


Table 3 (Cont'd)

\begin{tabular}{|c|c|c|c|c|c|c|c|c|c|}
\hline Unit & Level & 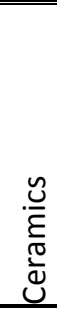 & 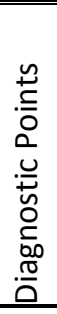 & 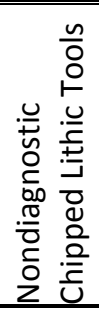 & 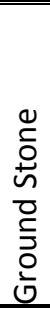 & 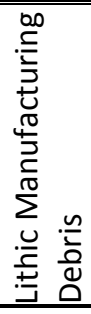 & 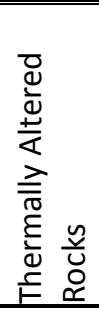 & 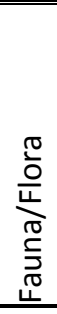 & 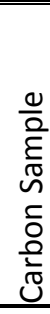 \\
\hline \multirow[t]{11}{*}{9} & 1 & 0 & 0 & 0 & 0 & 4 & 0 & 0 & 0 \\
\hline & 2 & 0 & 0 & 0 & 0 & 14 & 0 & 0 & 0 \\
\hline & 3 & 0 & 0 & 0 & 0 & 5 & 0 & 0 & 0 \\
\hline & 4 & 0 & 0 & 0 & 0 & 4 & 0 & 0 & 0 \\
\hline & 5 & 0 & 0 & 0 & 0 & 1 & 0 & 0 & 0 \\
\hline & 6 & 0 & 0 & 0 & 0 & 4 & 0 & 0 & 0 \\
\hline & 7 & 0 & 0 & 0 & 0 & 0 & 0 & 0 & 0 \\
\hline & 8 & 0 & 0 & 0 & 0 & 3 & 0 & 0 & 0 \\
\hline & 9 & 0 & 0 & 0 & 0 & 2 & 0 & 0 & 0 \\
\hline & 10 & 0 & 0 & 0 & 0 & 4 & 0 & 0 & 0 \\
\hline & 11 & 0 & 0 & 0 & 0 & 0 & 0 & 0 & 0 \\
\hline \multicolumn{2}{|c|}{ Unit Subtotal } & 0 & 0 & 0 & 0 & 41 & 0 & 0 & 0 \\
\hline \multicolumn{2}{|c|}{ Group Total } & 4 & 0 & 0 & 0 & 103 & 4 & 0 & 0 \\
\hline \multicolumn{2}{|c|}{ Site Total } & 16 & 4 & 6 & 2 & 725 & 13 & 0 & 2 \\
\hline
\end{tabular}

exhibiting compact to loose, sandy loam over loose sand with hematite and manganese inclusions, underlain by a zone of loose sandy loam.

Units 8 and 9 exhibited a relatively even distribution of material throughout the culture-bearing zone. Unit 8 contained 61 pieces of nondiagnostic lithic debitage, 1 core, 4 prehistoric ceramic sherds, and 4 pieces of thermally altered hematitic sandstone. Unit 9 contained 41 pieces of nondiagnostic lithic debitage. The artifacts were relatively evenly distributed between about 10 and $120 \mathrm{cmbs}$ in Unit 8 and between about 10 and $100 \mathrm{cmbs}$ in Unit 9.

\section{LITHIC ANALYSIS}

The artifact assemblage recovered during testing at site 41 SM385 includes 765 stone artifacts, including 12 tools, 1 core, and 752 debitage fragments (Appendix B). The most common artifactual raw material type is silicified wood, accounting for 36.0 percent of the assemblage $(n=277)$, followed closely by metaquartzite, accounting for 37.1 percent of the assemblage $(n=283)$. Chert is the third most common material, accounting for 21.1 percentage of the total $(n=161)$. 
Orthoquartzite accounts for 4.7 percent of the assemblage $(n=36)$, hematitic sandstone accounts for 0.8 percent $(n=6)$, and novaculite accounts for 0.3 percent $(n=2)$.

The debitage includes 35 primary flakes, accounting for 4.7 percent of the debitage assemblage, 335 secondary flakes (44.5 percent), 375 tertiary flakes (49.9 percent), 3 corticated chips ( 0.4 percent), 4 decorticated chips ( 0.5 percent), and 1 core $(0.1$ percent).

\section{Chipped Stones}

Chipped stone tools recovered from the investigation include one small Kent dart point, two small Gary dart points, one unidentified dart point, three biface fragments, two unifacially modified flakes, and one utilized flakes (Table 4). These artifacts are described below.

Table 4: Summary of Chipped Lithic Tools Recovered in NRHP Testing of Site 41SM385

\begin{tabular}{cccccll}
\hline $\begin{array}{c}\text { Unit } \\
\text { No. }\end{array}$ & Level & $\begin{array}{c}\text { Depth } \\
(\mathrm{cmbd})\end{array}$ & $\begin{array}{c}\text { Lot } \\
\text { No. }\end{array}$ & $\begin{array}{c}\text { FS } \\
\text { No. }\end{array}$ & Material & \\
\hline 1 & 2 & $20-30$ & 29.1 & 53 & chert & \multicolumn{1}{c}{ Tool Type } \\
1 & 4 & $40-50$ & 31.1 & 56 & metaquartzite & biface proximally modified flake \\
1 & 9 & $90-100$ & 92.1 & 117 & chert & small Gary dart point \\
2 & 3 & $30-40$ & 36.18 & 31 & silicified wood & biface proximal fragment, probable point stem \\
3 & 8 & $90-100$ & 98.1 & 129 & chert & unifacially modified flake \\
4 & 6 & $60-70$ & 60.1 & 66 & chert & small unidentified dart point missing base \\
4 & 7 & $70-80$ & 61.1 & 69 & metaquartzite & biface distal fragment, probable point stem \\
4 & 11 & $110-120$ & 103 & 125 & chert & utilized flake \\
5 & 7 & $80-90$ & 104.1 & 126 & chert & small Kent dart point \\
6 & 6 & $60-70$ & 70 & 104 & metaquartzite & small Gary dart point \\
\hline
\end{tabular}

\section{Projectile Points}

Lot 70 is a Gary dart point manufactured from metaquartzite that has been thermally altered. The artifact has a very small triangular-shaped body, contracting stem, convex basal edge, small but distinct shoulders, and relatively straight lateral margins (Figure 12a). The distal tip has been resharpened, and the dart point currently is 21.8 millimeters ( $\mathrm{mm}$ ) long, $15.5 \mathrm{~mm}$ wide, and $5.9 \mathrm{~mm}$ thick. The tip is slightly polished, suggesting usage against a soft material. The artifact is generally consistent with the Hobson variety of the Gary type proposed by Johnson (1962:162163). 


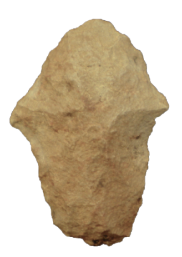

a) Lot 70

Reworked Gary Dart Point Metaquartzite

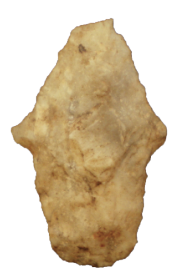

b) Lot 92.1

Reworked Gary Dart Point Chert

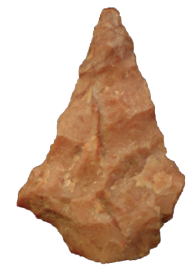

d) Lot 60.1

Untyped Dart Point Fragment Chert

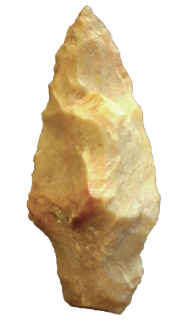

c) Lot 104.1

Reworked Kent Dart Point Chert

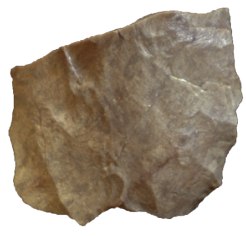

e) Lot 31.1

Biface Fragment Metaquartzite

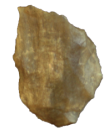

f) Lot 36.18

Biface Fragment Silicified Wood

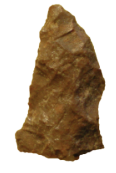

g) Lot 61.1

Biface Fragment Metaquartzite

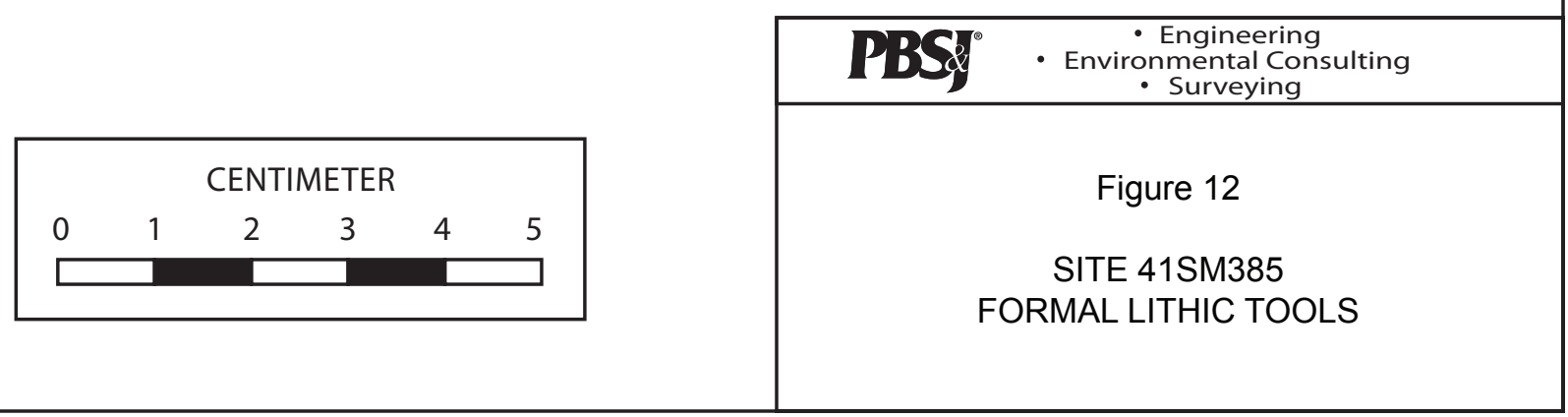

L:Projects $\backslash$ He $\backslash$ CLIENTS\NET RMA $\backslash$ Testing at 41SM385 \cad\Formal Lithic Tools 
Lot 92.1 is a Gary dart point manufactured from a medium-grained chert. The artifact has a very small triangular-shaped body, contracting stem, convex basal edge, small but distinct shoulders, and relatively straight lateral margins (Figure 12b). The distal tip has been resharpened, and the artifact is currently $24.2 \mathrm{~mm}$ long, $14.9 \mathrm{~mm}$ wide, and $6.4 \mathrm{~mm}$ thick. The artifact is generally consistent with the Hobson variety of the Gary type proposed by Johnson (1962:162-163).

Lot 104.1 is a Kent dart point manufactured from a medium-grained chert. The artifact has a triangular-shaped body, short contracting stem, convex basal edge, weak shoulders, and slightly convex lateral margins (Figure 12c). The tip and lateral margins of the artifact appear to have been reworked. The artifact is currently $30.1 \mathrm{~mm}$ long, $13.3 \mathrm{~mm}$ wide, and $7.4 \mathrm{~mm}$ thick.

Lot 60.1 is a dart point of an unidentified type. It is manufactured from a medium-grained chert with many inclusions. The artifact has a prominent medial ridge on both faces, well-thinned, concave lateral margins, and distinct shoulders (Figure 12d). The stem is missing. The tip and lateral margins of the artifact appear to have been reworked. The artifact is currently $25.4 \mathrm{~mm}$ long, $17.0 \mathrm{~mm}$ wide, and $7.1 \mathrm{~mm}$ thick. The general morphology of the artifact is consistent with the Gary point type, but in the absence of the stem, identification is speculative. Pronounced wear to the lateral margins near the tip suggests that the artifact was used as a perforator.

\section{Bifaces}

Lot 31.1 appears to be a basal fragment of a large, relatively thin preform or knife manufactured from thermally altered metaquartzite (Figure 12e). The artifact is currently $21.2 \mathrm{~mm}$ long, $22.7 \mathrm{~mm}$ wide, and $7.8 \mathrm{~mm}$ thick. There is slight edge rounding on one lateral edge suggestive of lateral utilization against a soft material such as cutting.

Lot 36.18 appears to be a basal fragment of a dart point manufactured from silicified wood (Figure 12f), possibly a manufacturing failure. The artifact is currently $12.1 \mathrm{~mm}$ long, $9.2 \mathrm{~mm}$ wide, and $3.6 \mathrm{~mm}$ thick. No evidence of utilization is present.

Lot 61.1 appears to be a distal fragment, possibly a projectile point stem or barb or a perforator. It is manufactured from metaquartzite (Figure 12g). The artifact is currently $16.1 \mathrm{~mm}$ long, $8.8 \mathrm{~mm}$ wide, and $4.7 \mathrm{~mm}$ thick. There is edge rounding on the lateral margins, suggestive of use as a perforator. The artifact has been thermally altered, most likely after manufacture.

\section{Unifacially Modified and Utilized Flakes}

Three artifacts are flakes or fragments that exhibit minimal cultural modification and/or utilization (lots 29.1, 98.1, 103). All were manufactured from chert. Evidence of utilization was generally slight and suggestive of short-term usage against soft or medium material.

The small percentage of formal tools other than projectile points suggests that site 41SM385 likely represents a series of short-term encampments associated with nonspecific resource procurement 
activities. The small Gary and Kent dart points are characteristic of the Woodland period in this region, suggesting a substantial Woodland component at the site.

\section{Ground Stones}

Ground and battered stone tools are generalized tools in the sense that a single tool may not be functionally specific with regard to the manner in which it is used or the things it is used to process or prepare. To systematically classify these tools, it is important to use well-defined criteria for recognizing their diverse nature and possible function. Since a variety of processes can produce distinctive wear, tools were assigned to specific analytical categories on the basis of several key variables: the mechanical processes, the outcome of those processes, and the material being processed. Microscopic examination of each tool aided in the identification of the key mechanical processes and the subsequent wear patterns still visible on the tool. Because any specific tool can be used in a range of activities, multifunctional tools were categorized on the basis of the predominant type of wear still visible on the tool.

Two ground and battered stone artifacts were recovered from 41SM385, both of which are fragments of once larger tools. Although postdepositional erosion has affected the stones, remnants of wear patterns are still visible on each tool. Examination under 10x power binocular magnification revealed five types of wear: grinding, polishing, pecking, grooving, and striations. Based on the observed wear patterns, both tools fit within the morphological category of abraders. The general morphology and associated wear patterns observed on the two tools generally indicates abrasive use on softer material such as wood, bone, and/or fiber.

Specimen 56.3 is a small edge fragment from a silicified wood abrader recovered from Unit 4, Level 2. This very thin fragment weighs 0.42 grams (g) and is $30.1 \mathrm{~mm}$ long and $21.0 \mathrm{~mm}$ wide. Wear occurs along one edge and one plane surface. Several curved grooves emanate from the worked edge and crosscut the grain surface. Remnants of several closely spaced grooves follow the grain, and there are areas of polish atop and around the high-relief areas.

Specimen 64.26 is a fragment of a silicified wood abrader recovered from Unit 5, Level 3. The highly fractured fragment weighs $60.6 \mathrm{~g}$ and measures $52.6 \mathrm{~mm}$ long and $36.9 \mathrm{~mm}$ wide. Only a portion of the tool's worn end and side remains. In these areas, the stone exhibits a distinctive polish on its flattened end and side. Small multidirectional striations are visible across all surfaces, and pecking occurs in a small localized area on the flattened end (Figure 13).

\section{CERAMIC ANALYSIS}

The following is a discussion of the 18 prehistoric ceramic sherds recovered during testing conducted at 41SM385 in Smith County. 


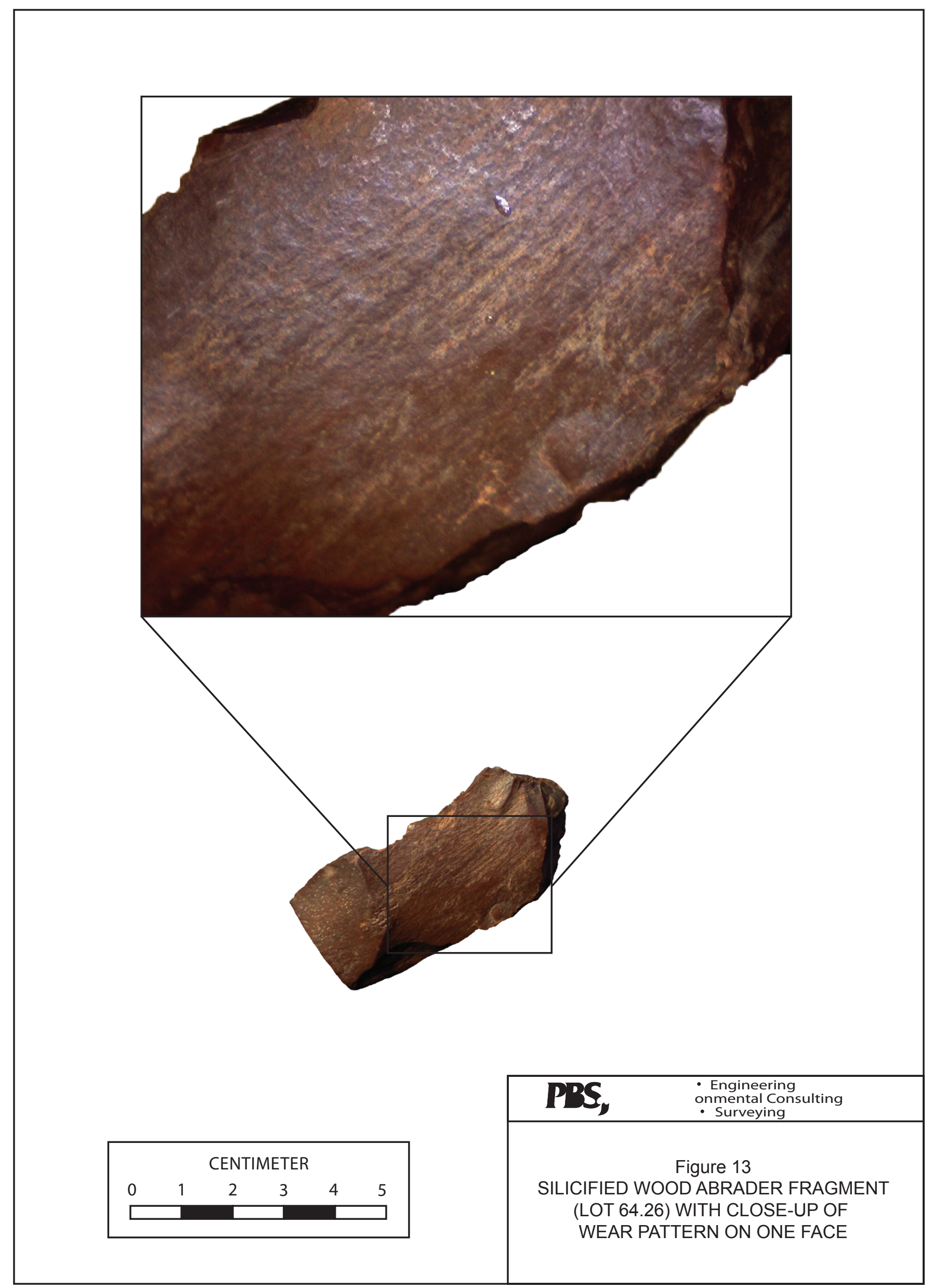




\section{Analytical Methods}

Analysis of the recovered ceramics focused primarily on their technological aspects and the observable modes that would aid in more-detailed classification. When whole vessels or sherds large enough to exhibit overall design motifs are present in the assemblage, typological classifications are possible. In the absence of whole vessels or vessel sections large enough to discern typologically distinct decorative motifs, one way to distinguish subtle differences between relatively similar ceramics is to look at the technological variations found on individual sherds (see Brown 1998; Lechtman 1977; Rice 1987; Rye 1981). Research indicates that for Caddo potters, variations in key technological attributes such as temper, surface treatment, and thickness bear a direct relationship to the desired use of the pot (see Perttula 2000, 2004, 2009a, 2009b; Rogers and Perttula 2004). Thus, sherds recovered from the site were characterized according to a suite of key technological attributes.

The analysis proceeded in two phases. The first phase involved an initial sort. All 18 sherds in the assemblage were examined in order to identify those that could be conjoined or confidently be determined to be part of the same vessel (i.e., fitters). During the initial sort, 8 sherds could be matched with other sherds. After fitters were identified, one undecorated body sherd with a maximum dimension of less than $2 \mathrm{~cm}$ was counted then culled from further analysis, leaving a total of 9 sherds in the analyzed sample (Figure 14).

The second phase involved a detailed analysis of technological attributes. All sherds in the analyzed sample were examined with respect to several key attributes (for detailed discussions of the analytical methods and definitions of the individual attributes, see Brown 1998; Ellis 1992, 1995; Perttula 2004; Phillips 1970). The technological attributes recorded for each sherd in the analyzed sample included (1) paste constituency (i.e., identification of the type of nonplastic inclusions [i.e., sand, bone, grog]), the predominant size range of nonplastic inclusions [i.e., medium sand, fine sand, very fine sand], and texture; (2) exterior and interior surface treatment; (3) exterior and interior decorative treatment; (4) morphological class (i.e., body, base, or rim); (5) average thickness; and (6) firing environment (i.e., oxidizing vs. nonoxidizing). Each of these attributes provides information about technological variability enabling finer-grained distinctions, which in turn allow the analyst to more fully characterize the assemblage even in the absence of identifiable types, thereby providing a basis for placing the ceramics within a broader regional ceramic context.

\section{Description of Ceramics}

Microscopic examination of freshly broken cross sections revealed two paste groups (Table 5). The basic paste fabric of each sherd in the sample started with very fine to silty clay to which varying combinations of nonplastic inclusions had been added. The presence of specific sets of tempering agents determined group designations, with bone and/or grog being the primary designators. The 


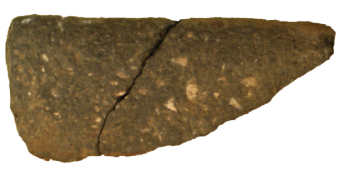

a) Lot 75.1

Bone-tempered

Plainware Rim Sherd

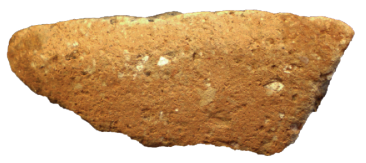

d) Lot 112.8

Bone-and-grog-tempered

Plainware Body Sherd

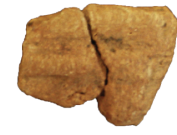

g) Lot 72.6

Bone-and-grog-tempered Decorated Body Sherd

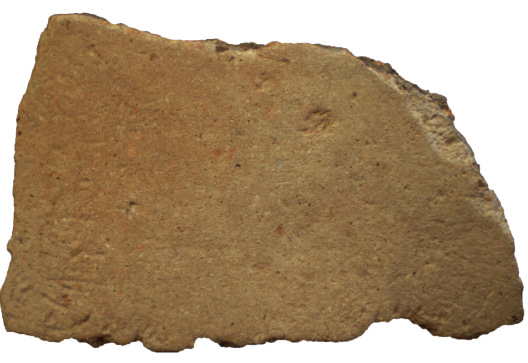

h) Lot 20

Bone-and-grog-tempered Plainware Lower Body Sherd

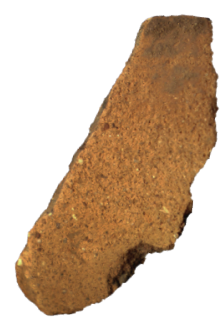

b) Lot 59.14

Bone-tempered

Plainware Body Sherd

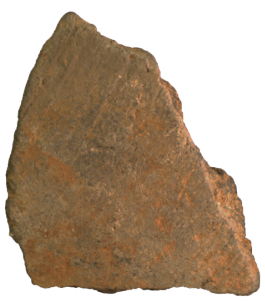

e) Lot 112.9

Brushed

Body Sherd

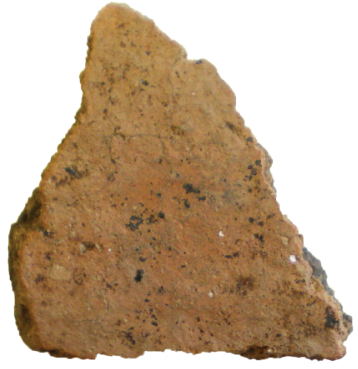

c) Lot 25

Bone-and-grog-tempered Plainware Body Sherd

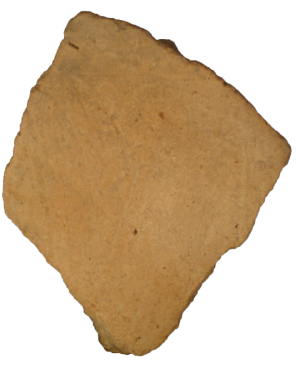

f) Lot 113.5

Brushed Ceramic

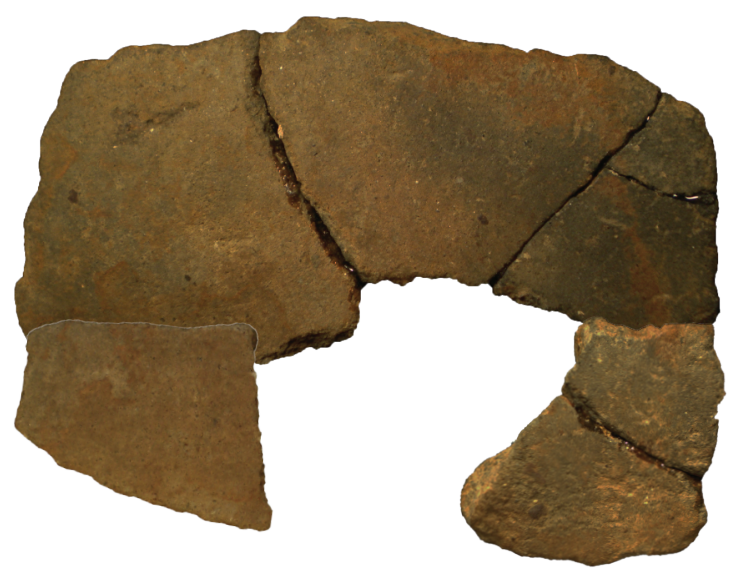

- Engineering

- Environmental Consulting - Surveying

Figure 14

SITE 41SM385

PREHISTORIC CERAMICS 
Table 5: Ceramic Attributes

\begin{tabular}{|c|c|c|c|c|c|c|c|c|c|c|c|c|c|c|c|c|}
\hline $\begin{array}{l}\text { Lot } \\
\text { No. }\end{array}$ & $\begin{array}{l}\text { Unit } \\
\text { No. }\end{array}$ & $\begin{array}{l}\text { ST } \\
\text { No. }\end{array}$ & Level & $\begin{array}{l}\text { Depth } \\
\text { (cmbs) }\end{array}$ & $\begin{array}{l}\text { Depth } \\
\text { (cmbs) }\end{array}$ & Class & Paste & $\begin{array}{l}\text { Paste } \\
\text { Texture }\end{array}$ & Exterior Surface & Interior Surface & $\begin{array}{l}\text { Exterior } \\
\text { Decoration }\end{array}$ & $\begin{array}{l}\text { Interior } \\
\text { Decoration }\end{array}$ & $\begin{array}{l}\text { Decorative } \\
\text { Motif }\end{array}$ & $\begin{array}{l}\text { Average } \\
\text { Thickness } \\
(\mathrm{mm})\end{array}$ & $\begin{array}{c}\text { Firing } \\
\text { Conditions }\end{array}$ & $\begin{array}{c}\text { Bulk Organic } \\
\text { Carbon Date } \\
\text { (2 Sigma) }\end{array}$ \\
\hline 20 & & 43 & 7 & 65 & & $\begin{array}{l}\text { Lower } \\
\text { Body }\end{array}$ & $\begin{array}{l}\text { Bone, grog, and crushed } \\
\text { hematite in a silty paste }\end{array}$ & Irregular & $\begin{array}{l}\text { Dry-smoothed, } \\
\text { Unburnished }\end{array}$ & $\begin{array}{l}\text { Dry-smoothed, } \\
\text { Unburnished }\end{array}$ & None & None & None & 9.2 & $\begin{array}{l}\text { Partially } \\
\text { Oxidized }\end{array}$ & - \\
\hline 25 & & 50 & 4 & 35 & & Body & $\begin{array}{l}\text { Bone, grog, and larger sized } \\
\text { sand grains in a silty paste }\end{array}$ & Irregular & Red Floated, Unburnished & $\begin{array}{l}\text { Floated, } \\
\text { Unburnished }\end{array}$ & None & None & None & 8.5 & $\begin{array}{l}\text { Partially } \\
\text { Reduced }\end{array}$ & A.D. $990-1160$ \\
\hline 41.1 & 3 & & 1 & & $10-19$ & Body & $\begin{array}{l}\text { Bone, grog, and larger sized } \\
\text { sand grains in a very fine sandy } \\
\text { paste }\end{array}$ & Irregular & $\begin{array}{l}\text { Dry-smoothed, } \\
\text { Unburnished }\end{array}$ & Weathered & None & None & None & 6.1 & Reduced & A.D. $250-430$ \\
\hline 59.14 & 4 & & 5 & & $50-60$ & Body & $\begin{array}{l}\text { Bone, crushed hematite, and } \\
\text { larger sized sand grains in a } \\
\text { silty paste }\end{array}$ & Irregular & Floated, Unburnished & Weathered & None & None & None & 5.8 & $\begin{array}{l}\text { Partially } \\
\text { Oxidized }\end{array}$ & - \\
\hline 72.6 & 7 & & 3 & & $30-40$ & Body & $\begin{array}{l}\text { Bone, grog, and larger sized } \\
\text { sand grains in a silty paste }\end{array}$ & Irregular & $\begin{array}{l}\text { Dry-smoothed, } \\
\text { Unburnished }\end{array}$ & Weathered & $\begin{array}{l}\text { Wide incised } \\
\text { lines }\end{array}$ & None & $\begin{array}{l}\text { Remnants of } 2 \\
\text { wide, vertical } \\
\text { incised lines }\end{array}$ & - & Oxidized & - \\
\hline 75.1 & 7 & & 6 & & $60-70$ & Plain Rim & Bone in a silty paste & Irregular & Weathered & Weathered & None & None & None & 5.4 & Reduced & $\begin{array}{l}\text { A.D. } 1300-1370 \\
\text { and A.D. } 1380- \\
1430\end{array}$ \\
\hline 112.8 & 8 & & 7 & & $70-80$ & Body & $\begin{array}{l}\text { Bone, grog, and crushed } \\
\text { hematite in a silty paste }\end{array}$ & Irregular & Red Floated, Unburnished & Weathered & None & None & None & 4.9 & $\begin{array}{l}\text { Partially } \\
\text { Reduced }\end{array}$ & - \\
\hline 112.9 & 8 & & 7 & & $70-80$ & $\begin{array}{l}\text { Decorated } \\
\text { Body }\end{array}$ & Bone and grog in a silty paste & Irregular & Floated, Unburnished & $\begin{array}{l}\text { Dry-smoothed, } \\
\text { Unburnished }\end{array}$ & Brushed & None & $\begin{array}{l}\text { Diagonal } \\
\text { brushing }\end{array}$ & 4.3 & Reduced & - \\
\hline 113.5 & 8 & & 8 & & $80-90$ & $\begin{array}{l}\text { Decorated } \\
\text { Body }\end{array}$ & $\begin{array}{l}\text { Bone, grog, and crushed } \\
\text { hematite in a silty paste }\end{array}$ & Irregular & Floated, Unburnished & $\begin{array}{l}\text { Floated, } \\
\text { Unburnished }\end{array}$ & Brushed & None & $\begin{array}{l}\text { Overlapping } \\
\text { brushing }\end{array}$ & 4.5 & $\begin{array}{l}\text { Partially } \\
\text { Oxidized }\end{array}$ & A.D. $1040-1240$ \\
\hline
\end{tabular}


sherds assigned to Group $1(n=2)$ had been tempered with crushed bone, crushed hematite, and/or larger sized sand grains (see Figure 14a-b). The sherds in Group $2(n=7)$ had been tempered with grog, bone, larger sized sand grains, and/or crushed hematite (see Figure 14c-i). Paste textures for the sherds in both groups were irregular (i.e., an uneven appearance due to the large inclusions added to the paste).

The exterior and/or interior surfaces of five sherds were too weathered to determine their original surface finish; however, three finishing techniques were still observable (see Table 5). Three sherds had one or more dry-smoothed surfaces. Five sherds had one or more floated surfaces. On two of those, a red pigment had been added to the water used to float the surface (see Figure 14c-d). None of the sherds had been burnished.

Three body sherds (33 percent) exhibited the remnants of at least one decorative element on their exterior surfaces (see Table 5; see Figure 14e-g). Two brushed sherds (lots 112.9 and 113.5; see Figure 14e-f) were recovered from Unit 8. One sherd (Lot 72.6; see Figure 14g), recovered from Unit 7, had the remnants of two wide, vertical incised lines; however, the sherd was too small to discern an overall design motif.

The sample included four undecorated body sherds, three decorated body sherds, one lower body sherd, and one undecorated rim. Based on the observed technological attributes, the nine sherds probably represent the remains of at least six different vessels. Sherd thickness was variable on each sherd. The body sherds ranged in thickness from $4.3 \mathrm{~mm}$ to $8.5 \mathrm{~mm}$, with an average thickness of $5.683 \mathrm{~mm} \pm 1.552 \mathrm{~mm}$. The thickest section of the lower body sherd measured $9.2 \mathrm{~mm}$. The rim sherd measured $5.4 \mathrm{~mm}$ in thickness along the edge opposite the lip edge. This undecorated rim was direct in profile and had been rounded flat along the lip edge. Determining vessel form was difficult given the size of the sherds; however, one of the body sherds (Lot 112.8) is a shoulder fragment suggesting the presence of at least one jar.

Based on the overall coloration and the presence or absence of a firing core, the majority of sherds had been fired in a reducing $(n=3)$ or partially reducing $(n=2)$ environment. This suggests that the vessels represented by the recovered sherds had been fired under variable less-controlled conditions.

\section{Summary}

Although the small sample size makes it difficult to draw specific conclusions about the 41SM385 ceramic assemblage, the technological attributes noted on the majority of the sherds is relatively consistent with ceramic assemblages found at Early to Middle Caddo sites throughout the region (see Perttula 2001, 2004; Perttula and Nelson 2004a, 2004b; Rogers and Perttula 2004). The sherds are relatively thin and the decorative techniques are those commonly found on Caddo ceramics. The overall distribution of paste categories and the heavy representation of sherds with bone and 
bone-and-grog temper with irregular paste textures also point to Caddo-made ceramics. Three of the four bulk carbon-dated sherds indicate Early to Middle Caddo occupations (see Table 5).

Interestingly, one of the bulk carbon-dated sherds (Lot 41.1; see Figure 14i) yielded a Woodland period date of A.D. 250-430 (Appendix C, Beta 28822). Although this particular sherd had a rather distinctive appearance, it did not fit the sorting criteria associated with Woodland period ceramics in that it was relatively thin and lacked the contorted or laminated pastes normally associated with these earlier-aged ceramics (see Table 5). There are two obvious possibilities for the age range of this sherd. Carbon in the clay needs to have been "recently living" at the time of manufacture and firing in order for the date to reflect the ceramic's period of use since the radiocarbon date represents the date of death of the organism from which the carbon was derived. So, if the clay used to manufacture the pot was taken from a stratigraphically early deposit and the carbon in the clay wasn't completely oxidized away, the radiocarbon date would yield a date that is closer in age to the deposition of the clay than it would be to the actual use of the pot (Darden Hood, personal communication 2010). Alternatively, if the clay was pulled from recent deposits at the time of manufacture and firing, and the only carbon present in it was "recent death" material) then firing would not matter and radiometric dating would yield a date representative of the period of use. If the date is correct and this sherd was in fact, manufactured during the Woodland period, then this illustrates the need for more-consistent sorting criteria for Woodland period ceramics.

\section{THERMALLY ALTERED ROCK ANALYSIS}

Fourteen specimens of fire-cracked or burned rock were recovered during NRHP testing investigations at site 41SM385. They include nine pieces of hematitic sandstone, two pieces of metaquartzite, and one each of chert, silicified wood, and hematite (Table 6). The specimens were recovered from between 10 and $90 \mathrm{cmbs}$, with one from Level 2, one from Level 3, three from Level 4, four from Level 5, four from Level 6, and one from Level 10. Eight of the specimens were from the area of artifact concentration sampled by units 1-5, one was from Shovel Test 23, one was from Unit 7, and four were from Unit 8.

\section{FAUNAL AND FLORAL REMAINS}

No vertebrate faunal remains or shell were recovered during the NRHP testing investigations at site 41SM385. Two small carbon samples were recovered from Unit 1, Level 8 (70-80 cmbs), and Unit 2, Level 9 (80-90 cmbs). Both appeared to be small, isolated charred wood fragments. Neither sample was viewed as being in an intact cultural context, so they were not subjected to further analysis. No burned nutshells, seeds, or other organic remains were recovered during the investigation. 
Table 6: Thermally Altered Rock Analysis

\begin{tabular}{|c|c|c|c|c|c|c|c|c|c|c|c|c|c|c|c|}
\hline Lot No. & Unit No. & ST No. & Level & $\begin{array}{l}\text { Depth } \\
\text { (cmbs) }\end{array}$ & $\begin{array}{l}\text { Depth } \\
(\mathrm{cmbd})\end{array}$ & Provenience & Northing & Easting & $\begin{array}{c}\text { No. of } \\
\text { Specimens }\end{array}$ & Era/ Phase & $\begin{array}{c}\text { Artifact } \\
\text { Material }\end{array}$ & $\begin{array}{c}\text { Use } \\
\text { Context }\end{array}$ & $\begin{array}{c}\text { Artifact } \\
\text { Description }\end{array}$ & $\begin{array}{c}\text { Artifact Sub- } \\
\text { description }\end{array}$ & $\begin{array}{c}\text { Artifact Form/ } \\
\text { Condition }\end{array}$ \\
\hline 13 & & 23 & 10 & $90-100$ & & & 75 & 50 & 1 & Unknown & Silicified Wood & Unknown & $\begin{array}{l}\text { Fire-cracked } \\
\text { Rocks }\end{array}$ & na & Fragment \\
\hline 32.10 & 1 & & 5 & & $50-60$ & & 77 & 51 & 1 & Unknown & $\begin{array}{l}\text { Hematitic } \\
\text { Sandstone }\end{array}$ & Unknown & Burned Rock & na & Fragment \\
\hline 33.8 & 1 & & 6 & & $60-70$ & & 77 & 51 & 1 & Unknown & Chert & Unknown & $\begin{array}{l}\text { Fire-cracked } \\
\text { Rocks }\end{array}$ & Shatter & Fragment \\
\hline 33.9 & 1 & & 6 & & $60-70$ & & 77 & 51 & 1 & Unknown & Hematite & Unknown & Burned Rock & na & Fragment \\
\hline 37.12 & 2 & & 4 & & $40-50$ & & 77 & 49 & 1 & Unknown & $\begin{array}{l}\text { Hematitic } \\
\text { Sandstone }\end{array}$ & Unknown & Burned Rock & na & Fragment \\
\hline 38.9 & 2 & & 5 & & $50-60$ & & 77 & 49 & 1 & Unknown & $\begin{array}{l}\text { Hematitic } \\
\text { Sandstone }\end{array}$ & Unknown & Burned Rock & na & Fragment \\
\hline 51.17 & 3 & & 6 & & $60-70$ & & 76 & 50 & 1 & Unknown & $\begin{array}{l}\text { Hematitic } \\
\text { Sandstone }\end{array}$ & Unknown & Burned Rock & na & Fragment \\
\hline 58.9 & 4 & & 4 & & $40-50$ & & 75 & 49 & 1 & Unknown & $\begin{array}{l}\text { Hematitic } \\
\text { Sandstone }\end{array}$ & Unknown & Burned Rock & na & Fragment \\
\hline 65.27 & 5 & & 4 & & $50-60$ & & 74 & 50 & 1 & Unknown & Metaquartzite & Unknown & $\begin{array}{l}\text { Fire-cracked } \\
\text { Rocks }\end{array}$ & Shatter & Fragment \\
\hline 76.3 & 7 & & 6 & & $60-70$ & & 67 & 59 & 1 & Unknown & $\begin{array}{l}\text { Hematitic } \\
\text { Sandstone }\end{array}$ & Unknown & Burned Rock & na & Fragment \\
\hline 79 & 8 & & 2 & & $20-30$ & NW Corner & 55 & 57 & 1 & Unknown & $\begin{array}{l}\text { Hematitic } \\
\text { Sandstone }\end{array}$ & Unknown & Burned Rock & na & Fragment \\
\hline 80.8 & 8 & & 3 & & $30-40$ & & 55 & 57 & 1 & Unknown & $\begin{array}{l}\text { Hematitic } \\
\text { Sandstone }\end{array}$ & Unknown & Burned Rock & na & Fragment \\
\hline 83.8 & 8 & & 5 & & $50-60$ & & 55 & 57 & 1 & Unknown & Metaquartzite & Unknown & $\begin{array}{l}\text { Fire-cracked } \\
\text { Rocks }\end{array}$ & Shatter & Fragment \\
\hline 83.9 & 8 & & 5 & & $50-60$ & & 55 & 57 & 1 & Unknown & $\begin{array}{l}\text { Hematitic } \\
\text { Sandstone }\end{array}$ & Unknown & Burned Rock & na & Fragment \\
\hline
\end{tabular}




\section{RADIOCARBON DATING ANALYSIS}

Four samples consisting of prehistoric ceramic sherds recovered during the NRHP testing investigations at site 41SM385 were selected for radiocarbon dating analysis and were submitted to Beta Analytic Inc. of Miami, Florida, for AMS dating.

Radiocarbon analysis of sample SM385-1 (Lot 25, see Figure 14c) recovered from Shovel Test 50, Level 4 (35 cmbs) resulted in a measured radiocarbon age of $1000 \pm 40$ B.P. with a 2-sigma calibration of A.D. 990 to 1160 (Cal B.P. 960 to 790) (Appendix C, Beta-28821).

Radiocarbon analysis of sample SM385-2 (Lot 41.1, see Figure 14i) recovered from Test Unit 3, Level 1 (0-10 cmbs) resulted in a measured radiocarbon age of $1630 \pm 40$ B.P. with a 2-sigma calibration of A.D. 250 to 430 (Cal B.P.1700 to 1520) (Appendix C, Beta-28822).

Radiocarbon analysis of sample SM385-3 (Lot 113.5, see Figure 14f) recovered from Test Unit 8, Level 6 (60-70 cmbs) resulted in a measured radiocarbon age of $900 \pm 40$ B.P. with a 2-sigma calibration of A.D. 1040 to 1240 (Cal B.P. 920 to 700) (Appendix C, Beta-28824).

Radiocarbon analysis of sample SM385-4 (Lot 75.1, see Figure 14a) recovered from Test Unit 7, Level 7 (70-80 cmbs) resulted in a measured radiocarbon age of $580 \pm 40$ B.P. with a 2-sigma calibration of A.D. 1300 to 1370 (Cal B.P. 650 to 580) and Cal A.D. 1380 to 1430 (Cal B.P. 570 to 520) (Appendix C, Beta-28823).

Samples SM385-1, 3, and 4 produced dates within the Early-Middle Caddo period. Sample SM385-2 produced a date within the middle part of the Woodland period. 


\section{CONCLUSIONS AND RECOMMENDATIONS}

Site 41SM385 appears to represent a Woodland- and Caddo-aged occupation on a small rise on the Indian Creek floodplain. The Woodland component is consistent with the Mill Creek Woodland culture (Black and Story 2003; Rogers et al. 2001) based on several characteristics including the paucity of ceramics and the small, less intensively utilized campsite occupation, compared with the Fourche Maline or Mossy Grove Woodland cultures, as well as the presence of small Gary and Kent projectile points. The Caddo component is based on ceramic sherds of probable Early or Middle Caddo origin identified at the site. The lack of identified cultural features suggests that the Woodland component probably represents a series of ephemeral usage of the location, probably as short-term campsites. The Caddo-aged artifacts at the site probably represent a series of ephemeral usage of the location, either as a resource procurement locus ancillary to nearby site 41SM404 or as a short-term campsite. The absence of cultural features and the paucity of lithic tools or ceramic remains make any more-specific functional interpretation infeasible.

While site 41SM385 is in the proposed ROW, it has been fenced to avoid construction impacts and is no longer in the project APE. No impacts to the site from the proposed project are anticipated.

Site 41SM385 is not thought to be eligible for listing in the NRHP (36 CFR 800.16[i] and 36 CFR 800.4(c)) or inclusion as a SAL (13 TAC $\$ 26.8(1)(2))$ for the following reasons. No discrete cultural deposits or cultural features were located during the investigation. Artifacts are generally evenly distributed over a wide vertical range with no clear vertical areas of substantially greater or lesser artifact density. The presence of both Woodland and Caddo occupations at the site without distinct spatial separation indicates that no discrete cultural components could be identified. This also precludes the potential for meaningful dating of occupations or gaining data on subsistence activities associated with these occupations. This site does not have the potential to yield any significant amount of additional data with more-extensive investigation. Therefore, no further investigation is recommended. 


\section{REFERENCES}

Ahr, S.

2001 Archeological Testing at the Prehistoric Site of 41SM231, Smith County, Texas. Occasional Papers of the Archeological Studies Program, Vol. 1, No. 2. Texas Department of Transportation, Austin.

Anderson, K.M.

1971 Archaeological Resources of Lake Palestine, Texas. Department of Anthropology, Southern Methodist University, Dallas. Submitted to National Park Service.

Anderson, K.M., K. Gilmore, O.F. McCormick III, and E.P. Morenon

1974 Archeological Investigations at Lake Palestine, Texas. Contributions in Anthropology 11. Southern Methodist University, Dallas.

Black, S., and D. Story

2003 "Caddo Ancestors: Woodland Cultures." Texas Beyond History. http://www. texasbeyondhistory.net/tejas/ancestors/woodland.html (accessed March 30, 2007).

Blair, W.F.

1950 The Biotic Provinces of Texas. Texas Journal of Science 2:93-117.

Brown, I.W.

1998 Decorated Pottery of the Lower Mississippi Valley: A Sorting Manual. Mississippi Archaeological Association, Mississippi Department of Archives and History.

Bruseth, J.E.

1975 Archaeological Survey and Testing in the Lake Fork Reservoir. Interim Report. Archaeology Research Program, Southern Methodist University, Dallas. Submitted to Sabine River Authority.

Bruseth, J.E., J.T. Bagot, K.M. Banks, and M.A. McKinley

1977 Archaeological Research at Lake Fork Reservoir: Site Inventory and Assessment. Research Report 87. Archaeology Research Program, Department of Anthropology, Southern Methodist University, Dallas.

Bruseth, J.E., and T.K. Perttula

1981 Prehistoric Settlement Patterns at Lake Fork Reservoir. Texas Antiquities Permit Series Report No. 2. Southern Methodist University, Dallas.

Bureau of Economic Geology (BEG)

1965 Geologic Atlas of Texas: Tyler Sheet. Bureau of Economic Geology, The University of Texas at Austin (scale 1:250,000).

Council of Texas Archeologists

1995 Council of Texas Archeologists Guidelines: Guidelines for Cultural Resources Management Reports. Distributed by the Council of Texas Archeologists, Austin. 
Davis, W.B., and D.J. Schmidly

1994 The Mammals of Texas. Texas Parks and Wildlife Department. Distributed by the University of Texas Press, Austin.

Duffield, L.F.

1960 Appraisal of the Archeological Resources of Flat Creek Reservoir, Henderson County, Texas. Texas Archeological Salvage Project, The University of Texas at Austin.

1961 The Limerick Site at Iron Bridge Reservoir, Rains County, Texas. Bulletin of the Texas Archeological Society 30:51-116.

Duffield, L.F., and E.B. Jelks

1961 The Pearson Site: A Historic Indian Site in Iron Bridge Reservoir, Rains County, Texas. Archaeology Series 4. Department of Anthropology, The University of Texas at Austin.

Ellis, L.W.

1992 Technological Style in Upper Texas Coastal Ceramics: A Case Study from Site 41HR616, Harris County, Texas. Unpublished Master's thesis, Department of Anthropology, The University of Texas at San Antonio.

1995 Ceramic Analysis. In Archeological Data Recovery Excavations at the Kingwood Site, 41HR616, Harris County, Texas. Edited by R.G. Moore, pp. 97-165. Report of Investigations Number 100. Moore Archeological Consulting, Houston, Texas.

Gibson, J.L.

1982 Archeological Reconnaissance in the Big Sandy Drainage Basin; An Empirical Approach to Investigating Settlement in East Texas. Center of Archaeological Studies, University of Southwestern Louisiana, Lafayette. Submitted to U.S. Army Corps of Engineers, Fort Worth District.

Girard, J.S.

1994 Investigations at the James Pace Site (16DS268), DeSoto Parish, Louisiana. Caddoan Archeology Newsletter 5(1):8-16.

Goldschmidt, W.R.

1935 Some Archaeological Sites in Titus County and Their Relation to East Texas Prehistory. Unpublished Master's thesis, Department of Anthropology, The University of Texas at Austin.

Goode, G.T.

1997 Test Excavation of Prehistoric Site 41SM203, Smith County, Texas. Texas Department of Transportation, Austin. Report on file, Texas Archeological Research Laboratory, The University of Texas at Austin.

Howard M., L.A. Garcia, M.D. McGuirt, L. Knight, A.J. Dodge, and C. Bece

1995 Archeological Survey of Tyler State Park, Smith County. Texas Parks and Wildlife Department, Austin. Report on file at the Texas Historical Commission, Austin. 
Jackson, A.T.

1936 A Perpetual Fire Site. Bulletin of the Texas Archeological and Paleontological Society 8:134-174.

Jarvis, R.W.

1972 The Folley Site: 41RK26. Texas Department of Highways and Transportation Publications in Archeology, Austin.

Jelks, E.B.

1958 Appraisal of the Archeological Resources of Blackburn Crossing Reservoir, Anderson, Cherokee, Henderson, and Smith Counties. U.S. Department of the Interior, National Park Service. Report on file at the Texas Historical Commission, Austin.

1965 The Archeology of McGee Bend Reservoir, Texas. Ph.D. dissertation, Department of Anthropology, The University of Texas at Austin.

Johnson, L., Jr.

1957 Appraisal of the Archeological Resources of Iron Bridge Reservoir, Hunt, Rains, and Van Zandt Counties, Texas. River Basin Surveys, Austin Office, National Park Service.

1958 Appraisal of the Archeological Resources of Blackburn Crossing Reservoir, Anderson, Cherokee, Henderson, and Smith Counties, Texas. Archeological Salvage Program, National Park Service.

1961 An Archeological Survey of Blackburn Crossing Reservoir on the Upper Neches River. Bulletin of the Texas Archeological Society 32:141-284.

1962 The Yarborough and Miller Sites of Northeastern Texas, with a Preliminary Definition of the La Harpe Aspect. Bulletin of the Texas Archeological Society 32:141284.

Kenmotsu, N.A., and T.K. Perttula (editors)

1993 Archeology in the Eastern Planning Region, Texas: A Planning Document. Department of Antiquities Protection, Cultural Resource Management Report 3. Texas Historical Commission, Austin.

Kleinschmidt, U.K.W.

1982 Review and Analysis of the A.C. Saunders Site, 41AN19, Anderson County, Texas. Unpublished Master's thesis, The University of Texas at Austin.

Lechtman, $\mathrm{H}$.

1977 Style in Technology - Some Early Thoughts. In Material Culture: Styles, Organization, and Dynamics of Technology, edited by H. Lechtman and R. S. Merrill, pp. 3-20. West Publishing, New York.

Malone, J.M.

1972 Archeological Reconnaissance at Proposed Mineola Reservoir. Archeological Survey Report 10. Texas Historical Survey Committee and Texas Water Development Board, Austin. 
McMahan, C.A., R.G. Frye, and K.L. Brown

1984 The Vegetation Types of Texas, Including Cropland: An Illustrated Synopsis to Accompany the Map. Texas Parks and Wildlife Department, Austin.

Middlebrook, T., and T.K. Perttula

1997 The Middle Caddoan Period in East Texas: A Summary of the Findings of the East Texas Caddoan Research. Journal of Northeast Texas Archaeology 9:1-8.

Nash, M.A., G. Sundborg, and J. Hageman

1993 A Cultural Resources Survey of the Proposed Coffee-Overton 138-kV Transmission Line Project, Anderson, Cherokee, Henderson, Rusk, and Smith Counties. Document No. 920744. Espey, Huston \& Associates, Inc., Austin.

Pemberton, F.H., R. Norris, and M.B. Cliff

2009 Intensive Archeological Survey for the North East Texas Regional Mobility Authority Proposed Loop 49, Segment 3A Between State Highway 31 and State Highway 155, Tyler, Smith County, Texas. Document No. 080104. PBS\&J, Dallas, Texas.

Perttula, T.K.

1986 Archeological Reconnaissance in the Water's Bluff and Upper Little Cypress Reservoirs, Gregg, Harrison, Smith, Upshur, and Wood Counties, Texas. Prewitt and Associates, Inc., Austin. Submitted to U.S. Department of the Interior, Bureau of Reclamation, Southwest Region, Amarillo, New Mexico.

1988 Cultural Setting. In Test Excavations at Sites 41BW182 and 41BW183, Red River Army Depot, Bowie County, Texas, edited by M.B. Cliff and D.E. Peter, pp. 11-25. RRAD/LSAAP Archeological Technical Series, Report of Investigations No. 1. GeoMarine, Inc., Plano.

1989 A Study of Mound Sites in the Sabine River Basin, Northeast Texas and Northwest Louisiana. Institute of Applied Sciences, North Texas State University, Denton.

1995 The Archeology of the Pineywoods and Post Oak Savannah of Northeast Texas. Bulletin of the Texas Archeological Society 66:331-359.

2000 Functional and Stylistic Analyses of Ceramic Vessels from Mortuary Features at a 15 th and 16th Century Caddo Site in Northeast Texas. Midcontinental Journal of Archaeology 25(1):101-151.

2001 Ceramic Analysis. In Excavations at the Herman Ballew Site (41RK222), Rusk County, Texas. By R. Rogers, M.A. Nash, and T.K. Perttula, pp. 98-130. PBS\&J, Document No. 15152. Austin.

2004 The Prehistoric and Caddoan Archeology of the Northeastern Texas Pineywoods. In The Prehistory of Texas, edited by T.K. Perttula, pp. 370-407. Texas A\&M University Press, College Station.

2009a Analysis of the Decorated Ceramics. In Data Recovery Investigations at the Ear Spool Site (41TT653), Titus County, Texas, By T.K. Perttula and D.L. Sherman, pp. 177-253. Document No. 070205. PBS\&J, Austin. 
2009b Detailed Analysis of Plain sherds and a Sample of Decorated from the Ear Spool site. In Data Recovery Investigations at the Ear Spool Site (41TT653), Titus County, Texas, By T.K. Perttula and D.L. Sherman, pp. 255-264. Document No. 070205. PBS\&J, Austin.

Perttula, T.K., and S. Black

2003 "Caddo Ancestors: Late Caddo, A.D. 1400-1680." Texas Beyond History. http://www.texasbeyondhistory.net/tejas/ancestors/late.html (accessed March 30, 2007).

Perttula, T.K., and J.E. Bruseth

1983 Early Caddoan Subsistence Strategies, Sabine River Basin, East Texas. Plains Anthropologist 28(99):9-22.

Perttula, T.K., and N.A. Kenmotsu

1993 Introduction to Section II: Regional Preservation Plan for Archeological Sites, Northeast Texas Archeological Region, Eastern Planning Region. In Archeology in the Eastern Planning Region, Texas: A Planning Document, edited by N.A. Kenmotsu and T.K. Perttula, pp. 34-47. Department of Antiquities Protection, Cultural Resource Management Report 3. Texas Historical Commission, Austin.

Perttula, T.K., and B. Nelson

1999 Archeological Survey of Proposed Waterlines for the Starrville Water Supply Corporation, Smith County, Texas. Archeological and Environmental Consultants, LLC, Austin. Report on file, Texas Archeological Research Laboratory, The University of Texas at Austin.

2000 Phase II Archeological Survey Investigations of the City of Tyler-Lake Palestine WTP Project, Smith County, Texas. Reports of Investigations No. 41. Archeological and Environmental Consultants, Austin.

2001a Archeological Test Excavations at the Prestonwood (41SM272) and Broadway (41SM273) Sites along the City of Tyler-Lake Palestine WTP Project, Smith County, Texas. Report of Investigations No. 43. Archeological and Environmental Consultants, LLC.

2001b Additional Archeological Survey Investigations, City of Tyler-Lake Palestine WTP Project, Smith County, Texas. Archeological and Environmental Consultants, LLC, Austin. Report on file, Texas Archeological Research Laboratory, University of Texas, Austin.

2004a Archeological Survey of Echard Heirs F and Anderson Well Pads and Access Road at Lake Tyler East for Antero Resources II, LP and the City of Tyler, Smith County, Texas. Archeological and Environmental Consultants, LLC, Austin. Report on file, Texas Archeological Research Laboratory, University of Texas, Austin.

2004b Woodland and Caddo Archeology at the Broadway or Kandutsah Site on the City of Tyler-Lake Palestine WTP Project, Smith County, Texas. Report of Investigations No. 50. Archeological and Environmental Consultants, LLC, Austin. 
2005 Archeological Survey of Echard Heirs C Well Pad and Access Road at Lake Tyler East for Antero Resources II, LP and the City of Tyler, Smith County, Texas. Archeological and Environmental Consultants, LLC, Austin. Report on file, Texas Archeological Research Laboratory, The University of Texas at Austin.

Perttula, T.K., B. Nelson, M. Walters, and C. Kugler

2003 Archeological Investigations at the Lindsey Park Site (41SM300), Smith County. Report of Investigations No. 62. Archeological and Environmental Consultants, LLC, Austin.

Perttula, T.K., and B. Skiles

1988 41RA65, An Early Ceramic-Early Caddoan Period Site on Garrett Creek, Rains County, Texas. The Record: Newsletter of the Dallas Archeological Society 42(3):6981.

Perttula, T.K., B. Skiles, M. Collins, M. Trachte, and F. Valdez, Jr.

1986 "This Everlasting Sand Bed": Cultural Resources Investigations at the Texas Big Sandy Project, Wood and Upshur Counties, Texas. Reports of Investigations No. 52. Prewitt \& Associates, Inc., Austin.

Phillips, P.

1970 Archaeological Survey in the Lower Yazoo Basin, Mississippi, 1949-1955. Papers of the Peabody Museum of Archaeology and Ethnology 60. Cambridge, Massachusetts.

Rice, P.M.

1987 Pottery Analysis: A Sourcebook. University of Chicago Press, Chicago.

Rogers, R., M.A. Nash, and T.K. Perttula

2001 Excavations at the Herman Ballew Site (41RK222), Rusk County, Texas. Document No. 000021. PBS\&J, Austin.

Rogers, R., and T.K. Perttula

2004 The Oak Hill Village Site (41RK214), Rusk County, Texas (contributions by J. Cogswell, B. Cruse, M. Cruse, P. Dering, K. Elson, C. Frederick, M. Glascock, A. Moss, M. Nash, H. Neff, K. Reese-Taylor, L. Shaw, C. Smith, E. Skokan-Switek, and M. Tate-Iruegas) Document No. 030083. PBS\&J, Austin.

Rye, 0 .

1981 Pottery Technology: Principles and Reconstruction. Taraxacum, Washington, D.C.

Schmidt, J.S.

1996 East Texas Electric Cooperative, Inc. Cultural Resources Survey (Clyde Brady Pecan Hills and Pecan Hills Garden Valley Segments), Smith County, Texas. Document No. 960206. Espey, Huston, and Associates, Inc., Austin.

Shafer, H.J.

2006 People of the Prairie: A Possible Connection to the Davis Site Caddo. Texas Department of Transportation, Environmental Affairs Division, Archeological 
Studies Program, G. Lain Ellis, Ph.D., Supervisor, and Prewitt and Associates, Inc., Cultural Resources Services, Austin.

Skiles, B.D.

1978 Early Archeological Investigations in the Lake Fork Reservoir Area. Ms. on file, Texas Archeological Research Laboratory, The University of Texas at Austin.

Skinner, S.A.

1971a Archeological Reconnaissance of Ponca Reservoir, Texas. Department of Anthropology, Southern Methodist University, Dallas. Submitted to National Park Service.

1971b Early Archeological Investigations in the Lake Fork Reservoir Area. Ms. on file, Texas Archeological Research Laboratory, The University of Texas at Austin.

1971c Historical Archeology of the Neches Saline, Smith County, Texas. Archeological Report 21. Texas Historical Survey Committee, Austin.

1975 A Preliminary Evaluation of Archeological Resources at Lake Fork Creek Reservoir, Wood County, Texas. Archaeology Research Program, Southern Methodist University, Dallas.

1999a Archaeological Survey of Faulkner Park, Smith County, Texas. Cultural Resources Report 99-26. AR Consultants, Dallas.

1999b Cultural Resource Reconnaissance of Pounds Field Airport, Smith County, Texas. AR Consultants, Dallas. Report on file, Texas Archeological Research Laboratory, The University of Texas at Austin.

Skokan, E.A., E.R. Foster, R.M. Rogers, D.L. Sherman, M.A. Nash, and J.B. Cruse

1997 Cultural Resources Investigations of the Oak Hill D-III Permit Area, Rusk County, Texas. 2 vols. Document No. 940002. Espey, Huston, \& Associates, Inc., Austin. Prepared for Texas Utilities Services, Inc., Dallas.

Soil Survey Staff

2004 Official Soil Series Description. "http//soils.usda.gov/technical/classification/osd/ index.html” (accessed 2 November 2010). Natural Resources Conservation Service, United States Department of Agriculture, Lincoln, Nebraska.

Story, D.A.

1965 The Archeology of Cedar Creek Reservoir, Henderson and Kaufman Counties, Texas. Bulletin of Texas Archeological Society 36:163-257.

1972 A Preliminary Report of the 1968, 1969 and 1970 Excavations at the George C. Davis Site, Cherokee County, Texas. Typewritten report submitted to the National Science Foundation (GS-2573, 3200) by the University of Texas at Austin, The Texas Building Commission, and the Texas Historical Survey Committee, Austin. 
1981 An Overview of the Archaeology of East Texas. Plains Anthropologist 26-92:135158.

1985 Adaptive Strategies of Archaic Cultures of the West Gulf Coastal Plain. In Prehistoric Food Production in North America, edited by R.I. Ford, pp. 19-56. Anthropological Papers No. 75. Museum of Anthropology, University of Michigan, Ann Arbor.

1990 Cultural History of the Native Americans. In Archeology and Bioarcheology of the Gulf Coastal Plain, Vol. 1, by D.A. Story, J.A. Guy, B.A. Burnett, M.D. Freeman, J.C. Rose, D.G. Steele, B.W. Olive, and K.J. Reinhard, pp. 163-366. Research Series No. 38. Arkansas Archeological Survey, Fayetteville.

Swanton, J.R.

1942 Source Material on the History and Ethnology of the Caddo Indians. Bulletin 132. Bureau of American Ethnology, Smithsonian Institution, Washington, D.C.

Texas Parks and Wildlife Department (TPWD)

1984 The Vegetation Types of Texas. Map prepared by GIS Lab, Texas Parks and Wildlife Department, a reproduction of an earlier map compiled by R.G. Frye, K.L. Brown, and C.A. McMahan, Texas Parks and Wildlife Department, 1984 (scale 1:950,400).

2004 Gould's Ecoregions of Texas. Map compiled by the Texas Parks and Wildlife Department GIS Lab, modified from Vegetational Areas of Texas, by F.W. Gould, G.O. Hoffman, and C.A. Rechenthin, Leaflet No. 492, Texas Agricultural Experiment Station, Texas A\&M University, College Station (no scale).

Thoms, A.V.

2004 Uncovering Camp Ford: Archaeological Interpretations of a Confederate Prisoner-ofWar Camp in East Texas. Reports of Investigation, No. 1. Center for Ecological Archaeology, Texas A\&M University, College Station.

Thurmond, V.P., II

1985 Late Caddoan Social Group Identifications and Sociopolitical Organization in the Upper Cypress Basin and Vicinity. Bulletin of the Texas Archeological Society 54:185200.

1988 Caddoan Archeology - Its Present Status and Future Directions: A Perspective from Northeast Texas. Paper presented at the 30th Caddo Conference, Dallas.

1990 Archeology of the Cypress Creek Drainage Basin, Northeastern Texas and Northwestern Louisiana. Studies in Archeology 5. Texas Archeological Research Laboratory, The University of Texas at Austin.

U.S. Department of Agriculture, Soil Conservation Service (USDA, SCS)

1993 Soil Survey of Smith County, Texas. U.S. Department of Agriculture, Soil Conservation Service, in cooperation with Texas Agricultural Experiment Station and Texas State Soil and Water Conservation Board. 
Walters M.

1997 The Langford Site (41SM197), Smith County, Texas. Journal of Northeast Texas Archaeology 9:38-41.

Walters M., and P. Haskins

2000 The Bryan Hardy Site (41SM55), Smith County, Texas. Journal of Northeast Texas Archaeology 12:1-26.

Webb, C.H., F.E. Murphy, W.G. Ellis, and H.R. Green

1969 The Resch Site, 41HS16, Harrison County, Texas. Bulletin of the Texas Archeological Society 40:3-106.

Whitsett, W.H.

1977 Archeological Reconnaissance at City of Tyler. Series C-481006-01. Report on file, Texas Archeological Research Laboratory, The University of Texas at Austin.

Wyckoff, D.G.

1974 The Caddoan Cultural Area: An Archaeological Perspective. In Caddoan Indians I, pp. 25-279. Garland Publishing, Inc., New York. 


\section{Appendix A}

\section{Specimen Inventory \\ (on CD)}


Depth Depth

Non Lithic Prehistoric Thermally Altered Rock Soil Carbon $\quad$ Size $\begin{gathered}\text { Magnetic } \\ \text { Susceptibility }\end{gathered}$

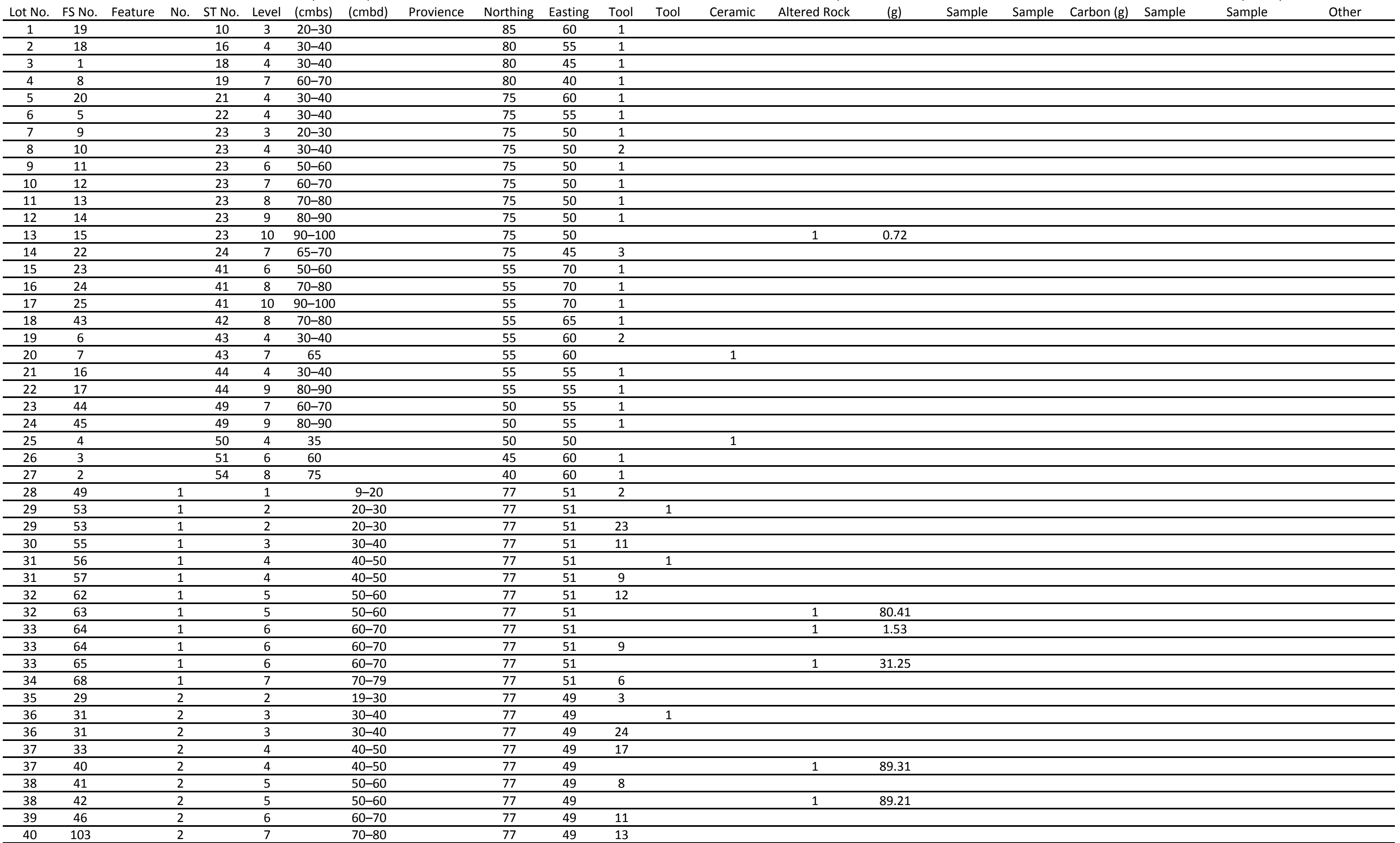




\begin{tabular}{|c|c|c|c|c|c|c|c|c|c|c|c|c|c|c|c|c|c|c|c|c|c|}
\hline Lot No. & FS No. & Feature & $\begin{array}{l}\text { Unit } \\
\text { No. }\end{array}$ & ST No. & Level & $\begin{array}{l}\text { Depth } \\
\text { (cmbs) }\end{array}$ & $\begin{array}{l}\text { Depth } \\
\text { (cmbd) }\end{array}$ & Provience & Northing & Easting & $\begin{array}{l}\text { Lithic } \\
\text { Non } \\
\text { Tool }\end{array}$ & $\begin{array}{l}\text { Lithic } \\
\text { Tool }\end{array}$ & $\begin{array}{c}\text { Prehistoric } \\
\text { Ceramic }\end{array}$ & $\begin{array}{l}\text { Thermally } \\
\text { Altered Rock }\end{array}$ & $\begin{array}{l}\text { Thermally } \\
\text { Altered Rock } \\
\text { (g) }\end{array}$ & $\begin{array}{c}\text { Soil } \\
\text { Sample }\end{array}$ & $\begin{array}{l}\text { Carbon } \\
\text { Sample }\end{array}$ & Carbon (g) & $\begin{array}{l}\text { Particle } \\
\text { Size } \\
\text { Sample }\end{array}$ & $\begin{array}{c}\text { Magnetic } \\
\text { Susceptibility } \\
\text { Sample }\end{array}$ & Other \\
\hline 41 & 26 & & 3 & & 1 & & $10-19$ & & 76 & 50 & & & & & & & & & & & \\
\hline 42 & 35 & & 3 & & 1 & & $10-19$ & SW Corner & 76 & 50 & & & & & & 1 & & & & & \\
\hline 43 & 28 & & 3 & & 2 & & $19-30$ & & 76 & 50 & 10 & & & & & & & & & & \\
\hline 44 & 36 & & 3 & & 2 & & $19-30$ & SW Corner & 76 & 50 & & & & & & 1 & & & & & \\
\hline 45 & 30 & & 3 & & 3 & & $30-40$ & & 76 & 50 & 14 & & & & & & & & & & \\
\hline 46 & 37 & & 3 & & 3 & & $30-40$ & SW Corner & 76 & 50 & & & & & & 1 & & & & & \\
\hline 47 & 32 & & 3 & & 4 & & $40-50$ & & 76 & 50 & 19 & & & & & & & & & & \\
\hline 48 & 38 & & 3 & & 4 & & $40-50$ & SW Corner & 76 & 50 & & & & & & 1 & & & & & \\
\hline 49 & 34 & & 3 & & 5 & & $50-60$ & & 76 & 50 & 6 & & & & & & & & & & \\
\hline 50 & 39 & & 3 & & 5 & & $50-60$ & SW Corner & 76 & 50 & & & & & & 1 & & & & & \\
\hline 51 & 47 & & 3 & & 6 & & $60-70$ & & 76 & 50 & 22 & & & & & & & & & & \\
\hline 51 & 48 & & 3 & & 6 & & $60-70$ & & 76 & 50 & & & & 1 & 62.11 & & & & & & \\
\hline 52 & 51 & & 3 & & 6 & & $60-70$ & SW Corner & 76 & 50 & & & & & & 1 & & & & & \\
\hline 53 & 101 & & 3 & & 7 & & $70-80$ & & 76 & 50 & 17 & & & & & & & & & & \\
\hline 54 & 102 & & 3 & & 7 & & $70-80$ & SW Corner & 76 & 50 & & & & & & 1 & & & & & \\
\hline 55 & 50 & & 4 & & 1 & & $12-20$ & & 75 & 49 & 1 & & & & & & & & & & \\
\hline 56 & 52 & & 4 & & 2 & & $20-30$ & & 75 & 49 & & 1 & & & & & & & & & \\
\hline 56 & 52 & & 4 & & 2 & & $20-30$ & & 75 & 49 & 2 & & & & & & & & & & \\
\hline 57 & 54 & & 4 & & 3 & & $30-40$ & & 75 & 49 & 25 & & & & & & & & & & \\
\hline 58 & 58 & & 4 & & 4 & & $40-50$ & & 75 & 49 & 14 & & & & & & & & & & \\
\hline 58 & 59 & & 4 & & 4 & & $40-50$ & & 75 & 49 & & & & 1 & 29.54 & & & & & & \\
\hline 59 & 61 & & 4 & & 5 & & $50-60$ & & 75 & 49 & 17 & & & & & & & & & & \\
\hline 59 & 61 & & 4 & & 5 & & $50-60$ & & 75 & 49 & & & 1 & & & & & & & & \\
\hline 60 & 66 & & 4 & & 6 & & $60-70$ & & 75 & 49 & & 1 & & & & & & & & & \\
\hline 60 & 67 & & 4 & & 6 & & $60-70$ & & 75 & 49 & 15 & & & & & & & & & & \\
\hline 61 & 69 & & 4 & & 7 & & $70-80$ & & 75 & 49 & & 1 & & & & & & & & & \\
\hline 61 & 70 & & 4 & & 7 & & $70-80$ & & 75 & 49 & 16 & & & & & & & & & & \\
\hline 62 & 94 & & 5 & & 1 & & $0-30$ & & 74 & 50 & 11 & & & & & & & & & & \\
\hline 63 & 95 & & 5 & & 2 & & $30-40$ & & 75 & 50 & 19 & & & & & & & & & & \\
\hline 64 & 96 & & 5 & & 3 & & $40-50$ & & 74 & 50 & 42 & & & & & & & & & & \\
\hline 64 & 97 & & 5 & & 3 & & $40-50$ & & 74 & 50 & & 1 & & & & & & & & & \\
\hline 65 & 98 & & 5 & & 4 & & $50-60$ & & 74 & 50 & & & & 1 & 2.32 & & & & & & \\
\hline 65 & 98 & & 5 & & 4 & & $50-60$ & & 74 & 50 & 56 & & & & & & & & & & \\
\hline 66 & 99 & & 5 & & 5 & & $60-70$ & & 74 & 50 & 30 & & & & & & & & & & \\
\hline 67 & 100 & & 5 & & 6 & & $70-80$ & & 74 & 50 & 17 & & & & & & & & & & \\
\hline 68 & 85 & & 6 & & 2 & & $20-30$ & & 67 & 62.5 & 5 & & & & & & & & & & \\
\hline 69 & 86 & & 6 & & 3 & & $30-40$ & & 67 & 62.5 & 4 & & & & & & & & & & \\
\hline 70 & 104 & & 6 & & 6 & & $60-70$ & SE Corner & 67 & 62.5 & & 1 & & & & & & & & & \\
\hline 71 & 105 & & 6 & & 7 & & $70-80$ & & 67 & 62.5 & 3 & & & & & & & & & & \\
\hline 72 & 87 & & 7 & & 3 & & $30-40$ & & 67 & 59 & & & 2 & & & & & & & & \\
\hline 72 & 88 & & 7 & & 3 & & $30-40$ & & 67 & 59 & 7 & & & & & & & & & & \\
\hline 73 & 89 & & 7 & & 4 & & $40-50$ & & 67 & 59 & 5 & & & & & & & & & & \\
\hline 74 & 90 & & 7 & & 5 & & $50-60$ & & 67 & 59 & 2 & & & & & & & & & & \\
\hline 75 & 91 & & 7 & & 6 & & $60-70$ & & 67 & 59 & & & 2 & & & & & & & & \\
\hline 76 & 92 & & 7 & & 6 & & $60-70$ & & 67 & 59 & & & & 1 & 128.19 & & & & & & \\
\hline 76 & 93 & & 7 & & 6 & & $60-70$ & & 67 & 59 & 2 & & & & & & & & & & \\
\hline 77 & 71 & & 8 & & 1 & & $7-20$ & & 55 & 57 & 2 & & & & & & & & & & \\
\hline 78 & 73 & & 8 & & 2 & & $20-30$ & & 55 & 57 & 7 & & & & & & & & & & \\
\hline
\end{tabular}




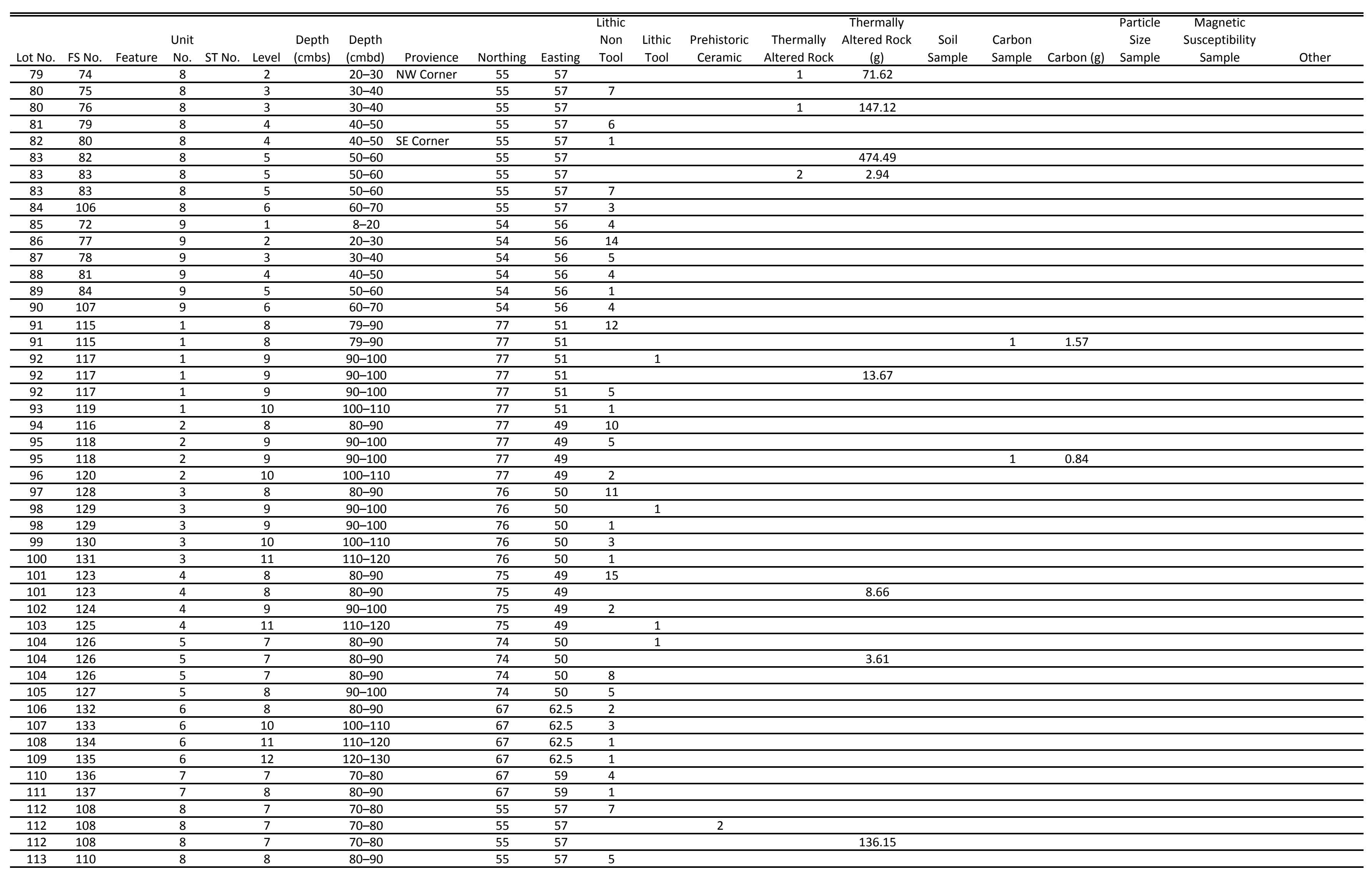




\begin{tabular}{|c|c|c|c|c|c|c|c|c|c|c|c|c|c|c|c|c|c|c|c|c|c|}
\hline Lot No. & FS No. & Feature & $\begin{array}{l}\text { Unit } \\
\text { No. }\end{array}$ & ST No. & Level & $\begin{array}{l}\text { Depth } \\
\text { (cmbs) }\end{array}$ & $\begin{array}{l}\text { Depth } \\
\text { (cmbd) }\end{array}$ & Provience & Northing & Easting & $\begin{array}{l}\text { Lithic } \\
\text { Non } \\
\text { Tool } \\
\end{array}$ & $\begin{array}{c}\text { Lithic } \\
\text { Tool } \\
\end{array}$ & $\begin{array}{c}\text { Prehistoric } \\
\text { Ceramic } \\
\end{array}$ & $\begin{array}{c}\text { Thermally } \\
\text { Altered Rock }\end{array}$ & $\begin{array}{c}\text { Thermally } \\
\text { Altered Rock } \\
\text { (g) }\end{array}$ & $\begin{array}{c}\text { Soil } \\
\text { Sample }\end{array}$ & $\begin{array}{l}\text { Carbon } \\
\text { Sample }\end{array}$ & Carbon (g) & $\begin{array}{c}\text { Particle } \\
\text { Size } \\
\text { Sample } \\
\end{array}$ & $\begin{array}{c}\text { Magnetic } \\
\text { Susceptibility } \\
\text { Sample } \\
\end{array}$ & Other \\
\hline 113 & 110 & & 8 & & 8 & & $80-90$ & & 55 & 57 & & & & & & & & & & & \\
\hline 113 & 110 & & 8 & & 8 & & $80-90$ & & 55 & 57 & & & & & 86.02 & & & & & & \\
\hline 114 & 113 & & 8 & & 9 & & $90-100$ & & 55 & 57 & 5 & & & & & & & & & & \\
\hline 114 & 113 & & 8 & & 9 & & $90-100$ & & 55 & 57 & & & 1 & & & & & & & & \\
\hline 115 & 114 & & 8 & & 10 & & $100-110$ & & 55 & 57 & 1 & & & & & & & & & & \\
\hline 116 & 121 & & 8 & & 11 & & $110-120$ & & 55 & 57 & 5 & & & & & & & & & & \\
\hline 117 & 122 & & 8 & & 12 & & $120-130$ & & 55 & 57 & 6 & & & & & & & & & & \\
\hline 118 & 109 & & 9 & & 8 & & $80-90$ & & 54 & 56 & 3 & & & & & & & & & & \\
\hline 119 & 111 & & 9 & & 9 & & $90-100$ & & 54 & 56 & 2 & & & & & & & & & & \\
\hline 120 & 112 & & 9 & & 10 & & $100-110$ & & 54 & 56 & 4 & & & & & & & & & & \\
\hline 121 & 138 & & 4 & & 1 & 10 & & North Wall & & & & & & & & & & & 1 & & \\
\hline 121 & 150 & & 4 & & 1 & 10 & & North Wall & & & & & & & & & & & & 1 & \\
\hline 122 & 139 & & 4 & & 2 & 20 & & North Wall & & & & & & & & & & & 1 & & \\
\hline 122 & 151 & & 4 & & 2 & 20 & & North Wall & & & & & & & & & & & & 1 & \\
\hline 123 & 140 & & 4 & & 3 & 30 & & North Wall & & & & & & & & & & & 1 & & \\
\hline 123 & 152 & & 4 & & 3 & 30 & & North Wall & & & & & & & & & & & & 1 & \\
\hline 124 & 141 & & 4 & & 4 & 40 & & North Wall & & & & & & & & & & & 1 & & \\
\hline 124 & 153 & & 4 & & 4 & 40 & & North Wall & & & & & & & & & & & & 1 & \\
\hline 125 & 142 & & 4 & & 5 & 50 & & North Wall & & & & & & & & & & & 1 & & \\
\hline 125 & 154 & & 4 & & 5 & 50 & & North Wall & & & & & & & & & & & & 1 & \\
\hline 126 & 143 & & 4 & & 6 & 60 & & North Wall & & & & & & & & & & & 1 & & \\
\hline 126 & 155 & & 4 & & 6 & 60 & & North Wall & & & & & & & & & & & & 1 & \\
\hline 127 & 144 & & 4 & & 7 & 70 & & North Wall & & & & & & & & & & & 1 & & \\
\hline 127 & 156 & & 4 & & 7 & 70 & & North Wall & & & & & & & & & & & & 1 & \\
\hline 128 & 145 & & 4 & & 8 & 80 & & North Wall & & & & & & & & & & & 1 & & \\
\hline 128 & 157 & & 4 & & 8 & 80 & & North Wall & & & & & & & & & & & & 1 & \\
\hline 129 & 146 & & 4 & & 9 & 90 & & North Wall & & & & & & & & & & & 1 & & \\
\hline 129 & 158 & & 4 & & 9 & 90 & & North Wall & & & & & & & & & & & & 1 & \\
\hline 130 & 147 & & 4 & & 10 & 100 & & North Wall & & & & & & & & & & & 1 & & \\
\hline 130 & 159 & & 4 & & 10 & 100 & & North Wall & & & & & & & & & & & & 1 & \\
\hline 131 & 148 & & 4 & & 11 & 110 & & North Wall & & & & & & & & & & & 1 & & \\
\hline 131 & 160 & & 4 & & 11 & 110 & & North Wall & & & & & & & & & & & & 1 & \\
\hline 132 & 149 & & 4 & & 12 & 120 & & North Wall & & & & & & & & & & & 1 & & \\
\hline 132 & 161 & & 4 & & 12 & 120 & & North Wall & & & & & & & & & & & & 1 & \\
\hline 133 & 162 & & 8 & & 1 & 10 & & North Wall & & & & & & & & & & & 1 & & \\
\hline 133 & 175 & & 8 & & 1 & 10 & & North Wall & & & & & & & & & & & & 1 & \\
\hline 134 & 163 & & 8 & & 2 & 20 & & North Wall & & & & & & & & & & & 1 & & \\
\hline 134 & 176 & & 8 & & 2 & 20 & & North Wall & & & & & & & & & & & & 1 & \\
\hline 135 & 164 & & 8 & & 3 & 30 & & North Wall & & & & & & & & & & & 1 & & \\
\hline 135 & 177 & & 8 & & 3 & 30 & & North Wall & & & & & & & & & & & & 1 & \\
\hline 136 & 165 & & 8 & & 4 & 40 & & North Wall & & & & & & & & & & & 1 & & \\
\hline 136 & 178 & & 8 & & 4 & 40 & & North Wall & & & & & & & & & & & & 1 & \\
\hline 137 & 166 & & 8 & & 5 & 50 & & North Wall & & & & & & & & & & & 1 & & \\
\hline 137 & 179 & & 8 & & 5 & 50 & & North Wall & & & & & & & & & & & & 1 & \\
\hline 138 & 167 & & 8 & & 6 & 60 & & North Wall & & & & & & & & & & & 1 & & \\
\hline 138 & 180 & & 8 & & 6 & 60 & & North Wall & & & & & & & & & & & & 1 & \\
\hline 139 & 168 & & 8 & & 7 & 70 & & North Wall & & & & & & & & & & & 1 & & \\
\hline 139 & 181 & & 8 & & 7 & 70 & & North Wall & & & & & & & & & & & & 1 & \\
\hline
\end{tabular}




\begin{tabular}{|c|c|c|c|c|c|c|c|c|c|c|c|c|c|c|c|c|c|c|c|c|c|}
\hline Lot No. & FS No. & Feature & $\begin{array}{l}\text { Unit } \\
\text { No. }\end{array}$ & ST No. & Level & $\begin{array}{l}\text { Depth } \\
\text { (cmbs) }\end{array}$ & $\begin{array}{l}\text { Depth } \\
\text { (cmbd) }\end{array}$ & Provience & Northing & Easting & $\begin{array}{l}\text { Lithic } \\
\text { Non } \\
\text { Tool } \\
\end{array}$ & $\begin{array}{c}\text { Lithic } \\
\text { Tool } \\
\end{array}$ & $\begin{array}{c}\text { Prehistoric } \\
\text { Ceramic } \\
\end{array}$ & $\begin{array}{c}\text { Thermally } \\
\text { Altered Rock }\end{array}$ & $\begin{array}{c}\text { Thermally } \\
\text { Altered Rock } \\
\text { (g) }\end{array}$ & $\begin{array}{c}\text { Soil } \\
\text { Sample }\end{array}$ & $\begin{array}{l}\text { Carbon } \\
\text { Sample }\end{array}$ & Carbon (g) & $\begin{array}{l}\text { Particle } \\
\text { Size } \\
\text { Sample } \\
\end{array}$ & $\begin{array}{c}\text { Magnetic } \\
\text { Susceptibility } \\
\text { Sample } \\
\end{array}$ & Other \\
\hline 140 & 169 & & 8 & & 8 & 80 & & North Wall & & & & & & & & & & & & & \\
\hline 140 & 182 & & 8 & & 8 & 80 & & North Wall & & & & & & & & & & & & 1 & \\
\hline 141 & 170 & & 8 & & 9 & 90 & & North Wall & & & & & & & & & & & 1 & & \\
\hline 141 & 183 & & 8 & & 9 & 90 & & North Wall & & & & & & & & & & & & 1 & \\
\hline 142 & 171 & & 8 & & 10 & 100 & & North Wall & & & & & & & & & & & 1 & & \\
\hline 142 & 184 & & 8 & & 10 & 100 & & North Wall & & & & & & & & & & & & 1 & \\
\hline 143 & 172 & & 8 & & 11 & 110 & & North Wall & & & & & & & & & & & 1 & & \\
\hline 143 & 185 & & 8 & & 11 & 110 & & North Wall & & & & & & & & & & & & 1 & \\
\hline 144 & 173 & & 8 & & 12 & 120 & & North Wall & & & & & & & & & & & 1 & & \\
\hline 144 & 186 & & 8 & & 12 & 120 & & North Wall & & & & & & & & & & & & 1 & \\
\hline 145 & 174 & & 8 & & 13 & 130 & & North Wall & & & & & & & & & & & 1 & & \\
\hline 145 & 187 & & 8 & & 13 & 130 & & North Wall & & & & & & & & & & & & 1 & \\
\hline 146 & 188 & & T4A & & 1 & 10 & & North Wall & & & & & & & & & & & & 1 & \\
\hline 146 & 202 & & T4A & & 1 & 10 & & North Wall & & & & & & & & & & & 1 & & \\
\hline 147 & 189 & & T4A & & 2 & 20 & & North Wall & & & & & & & & & & & & 1 & \\
\hline 147 & 203 & & T4A & & 2 & 20 & & North Wall & & & & & & & & & & & 1 & & \\
\hline 148 & 190 & & T4A & & 3 & 30 & & North Wall & & & & & & & & & & & & 1 & \\
\hline 148 & 204 & & T4A & & 3 & 30 & & North Wall & & & & & & & & & & & 1 & & \\
\hline 149 & 191 & & T4A & & 4 & 40 & & North Wall & & & & & & & & & & & & 1 & \\
\hline 149 & 205 & & T4A & & 4 & 40 & & North Wall & & & & & & & & & & & 1 & & \\
\hline 150 & 192 & & T4A & & 5 & 50 & & North Wall & & & & & & & & & & & & 1 & \\
\hline 150 & 206 & & T4A & & 5 & 50 & & North Wall & & & & & & & & & & & 1 & & \\
\hline 151 & 193 & & T4A & & 6 & 60 & & North Wall & & & & & & & & & & & & 1 & \\
\hline 151 & 207 & & T4A & & 6 & 60 & & North Wall & & & & & & & & & & & 1 & & \\
\hline 152 & 194 & & T4A & & 7 & 70 & & North Wall & & & & & & & & & & & & 1 & \\
\hline 152 & 208 & & T4A & & 7 & 70 & & North Wall & & & & & & & & & & & 1 & & \\
\hline 153 & 195 & & T4A & & 8 & 80 & & North Wall & & & & & & & & & & & & 1 & \\
\hline 153 & 209 & & T4A & & 8 & 80 & & North Wall & & & & & & & & & & & 1 & & \\
\hline 154 & 196 & & T4A & & 9 & 90 & & North Wall & & & & & & & & & & & & 1 & \\
\hline 154 & 210 & & T4A & & 9 & 90 & & North Wall & & & & & & & & & & & 1 & & \\
\hline 155 & 197 & & T4A & & 10 & 100 & & North Wall & & & & & & & & & & & & 1 & \\
\hline 155 & 211 & & T4A & & 10 & 100 & & North Wall & & & & & & & & & & & 1 & & \\
\hline 156 & 198 & & T4A & & 11 & 110 & & North Wall & & & & & & & & & & & & 1 & \\
\hline 156 & 212 & & T4A & & 11 & 110 & & North Wall & & & & & & & & & & & 1 & & \\
\hline 157 & 199 & & T4A & & 12 & 120 & & North Wall & & & & & & & & & & & & 1 & \\
\hline 157 & 213 & & T4A & & 12 & 120 & & North Wall & & & & & & & & & & & 1 & & \\
\hline 158 & 200 & & T4A & & 13 & 130 & & North Wall & & & & & & & & & & & & 1 & \\
\hline 158 & 214 & & T4A & & 13 & 130 & & North Wall & & & & & & & & & & & 1 & & \\
\hline 159 & 201 & & T4A & & 14 & 140 & & North Wall & & & & & & & & & & & & 1 & \\
\hline 159 & 215 & & T4A & & 14 & 140 & & North Wall & & & & & & & & & & & 1 & & \\
\hline- & 21 & & & 21 & 8 & $70-80$ & & & 75 & 60 & & & & & & & & & & & 1 (Noncultural) \\
\hline- & 27 & & 3 & & 2 & & $19-30$ & & 76 & 50 & & & & & & & & & & & \\
\hline- & 60 & & 4 & & 5 & & $50-60$ & & 75 & 49 & & & & & & & & & & & 1 (Noncultural) \\
\hline
\end{tabular}


Appendix B

Lithic Analysis

(on CD) 


\begin{tabular}{|c|c|c|c|c|c|c|c|c|c|c|c|c|c|c|c|c|c|c|c|c|c|c|c|}
\hline Lot No. & FS No. & $\begin{array}{l}\text { Unit } \\
\text { No. } \\
\end{array}$ & $\begin{array}{l}\text { ST } \\
\text { No. } \\
\end{array}$ & Level & $\begin{array}{l}\text { Depth } \\
\text { (cmbs) }\end{array}$ & $\begin{array}{l}\text { Depth } \\
\text { (cmbd) }\end{array}$ & Provience & Northing & Easting & $\begin{array}{c}\text { No. of } \\
\text { Specimens }\end{array}$ & $\begin{array}{c}\text { Time } \\
\text { Period } \\
\end{array}$ & Era/Phase & Artifact Material & Use Context & $\begin{array}{c}\text { Artifact } \\
\text { Description }\end{array}$ & $\begin{array}{c}\text { Artifact Sub- } \\
\text { description }\end{array}$ & $\begin{array}{c}\text { Artifact } \\
\text { Form/Condition }\end{array}$ & \begin{tabular}{|c} 
Surface \\
Treatment
\end{tabular} & Comments & $\begin{array}{c}\text { Weight in } \\
\text { grams }\end{array}$ & $\begin{array}{l}\text { Length in } \\
\mathrm{mm}\end{array}$ & $\begin{array}{l}\text { Width in } \\
\mathrm{mm}\end{array}$ & \begin{tabular}{|c|} 
Thickness in \\
$\mathrm{mm}$
\end{tabular} \\
\hline 1 & 19 & & 10 & 3 & $20-30$ & & & 85 & 60 & 1 & & Prehistoric & Chert & Unknown & Debitage & Tertiary Flake & Complete & na & na & na & na & na & na \\
\hline 2 & 18 & & 16 & 4 & $30-40$ & & & 80 & 55 & 1 & & Prehistoric & Silicified Wood & Unknown & Debitage & Tertiary Flake & Medial Fragment & na & na & na & na & na & na \\
\hline 3 & 1 & & 18 & 4 & $30-40$ & & & 80 & 45 & 1 & & Prehistoric & Metaquartzite & Unknown & \begin{tabular}{|l} 
Debitage \\
\end{tabular} & \begin{tabular}{|l|} 
Primary Flake \\
\end{tabular} & Proximal Fragment & na & na & na & na & na & na \\
\hline 4 & 8 & & 19 & 7 & $60-70$ & & & 80 & 40 & 1 & & Prehistoric & Orthoquartzite & Unknown & Debitage & 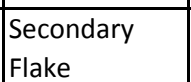 & Complete & $\begin{array}{l}\text { Thermally } \\
\text { Altered }\end{array}$ & na & na & na & na & na \\
\hline 5 & 20 & & 21 & 4 & $30-40$ & & & 75 & 60 & 1 & & Prehistoric & Chert & Unknown & Debitage & Tertiary Flake & Distal Fragment & na & na & na & na & na & na \\
\hline 6 & 5 & & 22 & 4 & $30-40$ & & & 75 & 55 & 1 & & Prehistoric & Metaquartzite & Unknown & Debitage & \begin{tabular}{|l|} 
Secondary \\
Flake
\end{tabular} & Medial Fragment & $\begin{array}{l}\text { Thermally } \\
\text { Altered }\end{array}$ & na & na & na & na & na \\
\hline 7 & 9 & & 23 & 3 & $20-30$ & & & 75 & 50 & 1 & & Prehistoric & Orthoquartzite & Unknown & \begin{tabular}{|l|l|} 
Debitage \\
\end{tabular} & Tertiary Flake & Distal Fragment & na & na & na & na & na & na \\
\hline 8.1 & 10 & & 23 & 4 & $30-40$ & & & 75 & 50 & 1 & & Prehistoric & Metaquartzite & Unknown & Debitage & \begin{tabular}{|l}
$\begin{array}{l}\text { Secondary } \\
\text { Flake }\end{array}$ \\
Fendare \\
Flake
\end{tabular} & Proximal Fragment & $\begin{array}{l}\text { Thermally } \\
\text { Altered }\end{array}$ & na & na & na & na & na \\
\hline 8.2 & 10 & & 23 & 4 & $30-40$ & & & 75 & 50 & 1 & & Prehistoric & Metaquartzite & Unknown & Debitage & \begin{tabular}{|l|} 
Secondary \\
Flake
\end{tabular} & Distal Fragment & $\begin{array}{l}\text { Thermally } \\
\text { Altered }\end{array}$ & na & na & na & na & na \\
\hline 9 & 11 & & 23 & 6 & 50-60 & & & 75 & 50 & 1 & & Prehistoric & Chert & Unknown & Debitage & Tertiary Flake & Complete & na & na & na & na & na & na \\
\hline 10 & 12 & & 23 & 7 & $60-70$ & & & 75 & 50 & 1 & & Prehistoric & Silicified Wood & Unknown & Debitage & \begin{tabular}{|l}
$\begin{array}{l}\text { Secondary } \\
\text { Flake }\end{array}$ \\
Fecolate \\
Flake
\end{tabular} & Complete & na & na & na & na & na & na \\
\hline 11 & 13 & & 23 & 8 & $70-80$ & & & 75 & 50 & 1 & & Prehistoric & Metaquartzite & Unknown & Debitage & $\begin{array}{l}\text { Secondary } \\
\text { Flake }\end{array}$ & Distal Fragment & \begin{tabular}{|l|} 
Thermally \\
Altered
\end{tabular} & na & na & na & na & na \\
\hline 12 & 14 & & 23 & 9 & $80-90$ & & & 75 & 50 & 1 & & Prehistoric & Metaquartzite & Unknown & Debitage & $\begin{array}{l}\text { Secondary } \\
\text { Flake }\end{array}$ & Medial Fragment & $\begin{array}{l}\text { Thermally } \\
\text { Altered }\end{array}$ & na & na & na & na & na \\
\hline 14.1 & 22 & & 24 & 7 & $\begin{array}{l}65-70 \\
\end{array}$ & & & 75 & 45 & 1 & & Prehistoric & Orthoquartzite & Unknown & Debitage & $\begin{array}{l}\text { Secondary } \\
\text { Flake }\end{array}$ & Distal Fragment & $\begin{array}{l}\text { Thermally } \\
\text { Altered }\end{array}$ & na & na & na & na & na \\
\hline 14.2 & 22 & & 24 & 7 & $65-70$ & & & 75 & 45 & 1 & & Prehistoric & Metaquartzite & Unknown & Debitage & $\begin{array}{l}\text { Secondary } \\
\text { Flake }\end{array}$ & Distal Fragment & $\begin{array}{l}\text { Thermally } \\
\text { Altered }\end{array}$ & na & na & na & na & na \\
\hline 14.3 & 22 & & 24 & 7 & $65-70$ & & & 75 & 45 & 1 & & Prehistoric & Metaquartzite & Unknown & Debitage & Tertiary Flake & Distal Fragment & $\begin{array}{l}\text { Thermally } \\
\text { Altered }\end{array}$ & na & na & na & na & na \\
\hline 15 & 23 & & 41 & 6 & $50-60$ & & & 55 & 70 & 1 & & Prehistoric & Silicified Wood & Unknown & Debitage & Tertiary Flake & Medial Fragment & na & na & na & na & na & na \\
\hline 16 & 24 & & 41 & 8 & $70-80$ & & & 55 & 70 & 1 & & Prehistoric & Chert & Unknown & Debitage & $\begin{array}{l}\text { Secondary } \\
\text { Flake }\end{array}$ & Complete & na & na & na & na & na & na \\
\hline 17 & 25 & & 41 & 10 & $90-100$ & & & 55 & 70 & 1 & & Prehistoric & Chert & Unknown & Debitage & Tertiary Flake & Distal Fragment & na & na & na & na & na & na \\
\hline 18 & 43 & & 42 & 8 & $70-80$ & & & 55 & 65 & 1 & & Prehistoric & Chert & Unknown & Debitage & Tertiary Flake & Proximal Fragment & na & Bifacial Thinning Flake & na & na & na & na \\
\hline 19.1 & 6 & & 43 & 4 & $30-40$ & & & 55 & 60 & 1 & & Prehistoric & Chert & Unknown & Debitage & Tertiary Flake & Medial Fragment & $\begin{array}{l}\text { Thermally } \\
\text { Altered }\end{array}$ & na & na & na & na & na \\
\hline 19.2 & 6 & & 43 & 4 & $30-40$ & & & 55 & 60 & 1 & & Prehistoric & Chert & Unknown & Debitage & Tertiary Flake & Distal Fragment & na & na & na & na & na & na \\
\hline 21 & 16 & & 44 & 4 & $30-40$ & & & 55 & 55 & 1 & & Prehistoric & Silicified Wood & Unknown & Debitage & Tertiary Flake & \begin{tabular}{|l} 
Proximal Fragment \\
\end{tabular} & na & na & na & na & na & na \\
\hline 22 & 17 & & 44 & 9 & $80-90$ & & & 55 & 55 & 1 & & Prehistoric & Chert & Unknown & Debitage & \begin{tabular}{|l|} 
Secondary \\
Flake
\end{tabular} & Medial Fragment & na & na & na & na & na & na \\
\hline 23 & 44 & & 49 & 7 & $60-70$ & & & 50 & 55 & 1 & & Prehistoric & Metaquartzite & Unknown & Debitage & Tertiary Flake & Distal Fragment & \begin{tabular}{|l|} 
Thermally \\
Altered
\end{tabular} & na & na & na & na & na \\
\hline 24 & 45 & & 49 & 9 & $80-90$ & & & 50 & 55 & 1 & & Prehistoric & Silicified Wood & Unknown & Debitage & Tertiary Flake & Complete & \begin{tabular}{|l|} 
Thermally \\
Altered
\end{tabular} & na & na & na & na & na \\
\hline 26 & 3 & & 51 & 6 & 60 & & & 45 & 60 & 1 & & Prehistoric & Chert & Unknown & Debitage & Tertiary Flake & Proximal Fragment & $\begin{array}{l}\text { Thermally } \\
\text { Altered }\end{array}$ & na & na & na & na & na \\
\hline
\end{tabular}




\begin{tabular}{|c|c|c|c|c|c|c|c|c|c|c|c|c|c|c|c|c|c|c|c|c|c|c|c|}
\hline Lot No. & FS No. & $\begin{array}{l}\text { Unit } \\
\text { No. }\end{array}$ & \begin{tabular}{|l|} 
ST \\
No. \\
\end{tabular} & Level & $\begin{array}{l}\text { Depth } \\
\text { (cmbs) }\end{array}$ & $\begin{array}{l}\text { Depth } \\
\text { (cmbd) }\end{array}$ & Provience & Northing & Easting & $\begin{array}{c}\text { No. of } \\
\text { Specimens }\end{array}$ & $\begin{array}{l}\text { Time } \\
\text { Period }\end{array}$ & Era/ Phase & Artifact Material & Use Context & $\begin{array}{c}\text { Artifact } \\
\text { Description }\end{array}$ & \begin{tabular}{|c|} 
Artiffact Sub- \\
description
\end{tabular} & $\begin{array}{c}\text { Artifact } \\
\text { Form/Condition }\end{array}$ & \begin{tabular}{|c|} 
Surface \\
Treatment
\end{tabular} & Comments & $\begin{array}{l}\text { Weight in } \\
\text { grams }\end{array}$ & $\begin{array}{l}\text { Length in } \\
\mathrm{mm}\end{array}$ & $\begin{array}{c}\text { Width in } \\
\mathrm{mm}\end{array}$ & \begin{tabular}{|c|} 
Thickness in \\
$\mathrm{mm}$
\end{tabular} \\
\hline 27 & 2 & & 54 & 8 & 75 & & & 40 & 60 & 1 & & Prehistoric & Metaquartzite & Unknown & Debitage & Tertiary Flake & Distal Fragment & na & na & na & na & 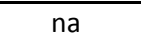 & na \\
\hline 28.1 & 49 & 1 & & 1 & & \begin{tabular}{|l|}
$9-20$ \\
\end{tabular} & & 77 & 51 & 1 & & Prehistoric & Silicified Wood & Unknown & Debitage & Tertiary Flake & Medial Fragment & na & na & na & na & na & na \\
\hline 28.2 & 49 & 1 & & 1 & & \begin{tabular}{|l|}
$9-20$ \\
\end{tabular} & & 77 & 51 & 1 & & Prehistoric & Metaquartzite & Unknown & Debitage & $\begin{array}{l}\text { Secondary } \\
\text { Flake }\end{array}$ & Distal Fragment & $\begin{array}{l}\text { Thermally } \\
\text { Altered }\end{array}$ & na & na & na & na & na \\
\hline 29.10 & 53 & 1 & & 2 & & $20-30$ & & 77 & 51 & 1 & & Prehistoric & Silicified Wood & Unknown & Debitage & $\begin{array}{l}\text { Secondary } \\
\text { Flake }\end{array}$ & Distal Fragment & na & na & na & na & na & na \\
\hline 29.1 & 53 & 1 & & 2 & & $20-30$ & & 77 & 51 & 1 & & Prehistoric & Chert & Unknown & \begin{tabular}{|l|} 
Unifacially \\
Modified \\
Flake
\end{tabular} & \begin{tabular}{|l} 
Secondary \\
Flake
\end{tabular} & Distal Fragment & $\begin{array}{l}\text { Thermally } \\
\text { Altered }\end{array}$ & \begin{tabular}{|l|} 
Unifacially modified along \\
concave distal edge $(6.63 \mathrm{~mm})$, \\
modified edge utilized on medium \\
soft material for planing activities; \\
unifacially modified along straight \\
lateral edge $(7.81 \mathrm{~mm})$, modified \\
edge utilized on medium hard \\
material for sawing activities
\end{tabular} & 1.13 & 16.20 & 18.17 & 5.59 \\
\hline 29.11 & 53 & 1 & & 2 & & $20-30$ & & 77 & 51 & 1 & & \begin{tabular}{|l|} 
Prehistoric \\
\end{tabular} & Silicified Wood & Unknown & Debitage & Tertiary Flake & Medial Fragment & na & na & na & na & na & na \\
\hline 29.12 & 53 & 1 & & 2 & & $20-30$ & & 77 & 51 & 2 & & Prehistoric & Silicified Wood & Unknown & Debitage & Tertiary Flake & Medial Fragment & $\begin{array}{l}\text { Thermally } \\
\text { Altered }\end{array}$ & na & na & na & na & na \\
\hline 29.13 & 53 & 1 & & 2 & & $20-30$ & & 77 & 51 & 1 & & Prehistoric & Silicified Wood & Unknown & Debitage & Tertiary Flake & Distal Fragment & na & na & na & na & na & na \\
\hline \begin{tabular}{|l|l|}
29.14 \\
\end{tabular} & 53 & 1 & & 2 & & $20-30$ & & 77 & 51 & 1 & & Prehistoric & Hematitic Sandstone & Unknown & Debitage & \begin{tabular}{|l} 
Secondary \\
Flake
\end{tabular} & Medial Fragment & \begin{tabular}{|l|} 
Thermally \\
Altered
\end{tabular} & na & na & na & na & na \\
\hline 29.2 & 53 & 1 & & 2 & & $20-30$ & & 77 & 51 & 1 & & Prehistoric & Chert & Unknown & Debitage & $\begin{array}{l}\text { Secondary } \\
\text { Flake }\end{array}$ & Medial Fragment & $\begin{array}{l}\text { Thermally } \\
\text { Altered }\end{array}$ & na & na & na & na & na \\
\hline 29.3 & 53 & 1 & & 2 & & $20-30$ & & 77 & 51 & 3 & & Prehistoric & Chert & Unknown & Debitage & $\begin{array}{l}\text { Secondary } \\
\text { Flake }\end{array}$ & Distal Fragment & $\begin{array}{l}\text { Thermally } \\
\text { Altered }\end{array}$ & na & na & na & na & na \\
\hline 29.4 & 53 & 1 & & 2 & & $20-30$ & & 77 & 51 & 4 & & Prehistoric & Metaquartzite & Unknown & Debitage & \begin{tabular}{|l} 
Secondary \\
Flake
\end{tabular} & Medial Fragment & \begin{tabular}{|l|} 
Thermally \\
Altered
\end{tabular} & na & na & na & na & na \\
\hline 29.5 & 53 & 1 & & 2 & & $20-30$ & & 77 & 51 & 3 & & Prehistoric & Metaquartzite & Unknown & Debitage & \begin{tabular}{|l} 
Secondary \\
Flake
\end{tabular} & Distal Fragment & \begin{tabular}{|l} 
Thermally \\
Altered
\end{tabular} & na & na & na & na & na \\
\hline 29.6 & 53 & 1 & & 2 & & $20-30$ & & 77 & 51 & 1 & & Prehistoric & Orthoquartzite & Unknown & Debitage & Tertiary Flake & Medial Fragment & $\begin{array}{l}\text { Thermally } \\
\text { Altered }\end{array}$ & na & na & na & na & na \\
\hline 29.7 & 53 & 1 & & 2 & & $20-30$ & & 77 & 51 & 2 & & Prehistoric & Metaquartzite & Unknown & Debitage & Tertiary Flake & Distal Fragment & $\begin{array}{l}\text { Thermally } \\
\text { Altered }\end{array}$ & na & na & na & na & na \\
\hline 29.8 & 53 & 1 & & 2 & & $20-30$ & & 77 & 51 & 1 & & $\begin{array}{l}\text { Prehistoric } \\
\end{array}$ & Silicified Wood & Unknown & Debitage & $\begin{array}{l}\text { Secondary } \\
\text { Flake }\end{array}$ & Medial Fragment & $\begin{array}{l}\text { Thermally } \\
\text { Altered }\end{array}$ & na & na & na & na & na \\
\hline 29.9 & 53 & 1 & & 2 & & $20-30$ & & 77 & 51 & 2 & & Prehistoric & Silicified Wood & Unknown & Debitage & \begin{tabular}{|l} 
Secondary \\
Flake
\end{tabular} & Distal Fragment & \begin{tabular}{|l} 
Thermally \\
Altered
\end{tabular} & na & na & na & na & na \\
\hline \begin{tabular}{ll|}
30.1 \\
\end{tabular} & 55 & 1 & & 3 & & $30-40$ & & 77 & 51 & 1 & & Prehistoric & Silicified Wood & Unknown & Debitage & $\begin{array}{l}\text { Secondary } \\
\text { Flake }\end{array}$ & Distal Fragment & $\begin{array}{l}\text { Thermally } \\
\text { Altered }\end{array}$ & na & na & na & na & na \\
\hline \begin{tabular}{ll|}
30.2 \\
\end{tabular} & 55 & 1 & & 3 & & $30-40$ & & 77 & 51 & 1 & & Prehistoric & Orthoquartzite & Unknown & Debitage & $\begin{array}{l}\text { Secondary } \\
\text { Flake }\end{array}$ & Medial Fragment & $\begin{array}{l}\text { Thermally } \\
\text { Altered }\end{array}$ & na & na & na & na & na \\
\hline 30.3 & 55 & 1 & & 3 & & $30-40$ & & 77 & 51 & 1 & & Prehistoric & Metaquartzite & Unknown & \begin{tabular}{|l|l|} 
Debitage \\
\end{tabular} & $\begin{array}{l}\text { Secondary } \\
\text { Flake }\end{array}$ & Complete & $\begin{array}{l}\text { Thermally } \\
\text { Altered }\end{array}$ & na & na & na & na & na \\
\hline 30.4 & 55 & 1 & & 3 & & $30-40$ & & 77 & 51 & 1 & & Prehistoric & Metaquartzite & Unknown & Debitage & $\begin{array}{l}\text { Secondary } \\
\text { Flake }\end{array}$ & Complete & na & na & na & na & na & na \\
\hline 30.5 & 55 & 1 & & 3 & & $30-40$ & & 77 & 51 & 1 & & Prehistoric & Orthoquartzite & Unknown & Debitage & Tertiary Flake & Complete & \begin{tabular}{|l|} 
Thermally \\
Altered \\
\end{tabular} & na & na & na & na & na \\
\hline 30.6 & 55 & 1 & & 3 & & $30-40$ & & 77 & 51 & 2 & & Prehistoric & Metaquartzite & Unknown & Debitage & Tertiary Flake & Medial Fragment & $\begin{array}{l}\text { Thermally } \\
\text { Altered }\end{array}$ & na & na & na & na & na \\
\hline
\end{tabular}




\begin{tabular}{|c|c|c|c|c|c|c|c|c|c|c|c|c|c|c|c|c|c|c|c|c|c|c|c|}
\hline Lot No. & FS No. & $\begin{array}{l}\text { Unit } \\
\text { No. }\end{array}$ & $\begin{array}{l}\text { ST } \\
\text { No. }\end{array}$ & Level & $\begin{array}{c}\text { Depth } \\
\text { (cmbs) }\end{array}$ & $\begin{array}{l}\text { Depth } \\
\text { (cmbd) }\end{array}$ & Provience & Northing & Easting & \begin{tabular}{|c|} 
No. of \\
Specimens
\end{tabular} & $\begin{array}{l}\text { Time } \\
\text { Period }\end{array}$ & Era/Phase & Artifact Material & Use Context & $\begin{array}{c}\text { Artifact } \\
\text { Description }\end{array}$ & $\begin{array}{c}\text { Artifact Sub- } \\
\text { description }\end{array}$ & $\begin{array}{c}\text { Artifact } \\
\text { Form/Condition }\end{array}$ & \begin{tabular}{|c} 
Surface \\
Treatment
\end{tabular} & Comments & $\begin{array}{l}\text { Weight in } \\
\text { grams }\end{array}$ & $\begin{array}{l}\text { Length in } \\
\mathrm{mm}\end{array}$ & $\begin{array}{c}\text { Width in } \\
\mathrm{mm}\end{array}$ & \begin{tabular}{|c|} 
Thickness in \\
$\mathrm{mm}$
\end{tabular} \\
\hline 30.7 & 55 & 1 & & 3 & & $30-40$ & & 77 & 51 & 2 & & Prehistoric & Silicified Wood & Unknown & Debitage & $\begin{array}{l}\text { Secondary } \\
\text { Flake }\end{array}$ & Medial Fragment & \begin{tabular}{|l} 
Thermally \\
Altered
\end{tabular} & na & na & na & na & na \\
\hline 30.8 & 55 & 1 & & 3 & & $30-40$ & & 77 & 51 & 2 & & Prehistoric & Silicified Wood & Unknown & Debitage & Tertiary Flake & Proximal Fragment & na & na & na & na & na & na \\
\hline 31.1 & 56 & 1 & & 4 & & $40-50$ & & 77 & 51 & 1 & & Prehistoric & Metaquartzite & Unknown & Biface & na & Proximal Fragment & \begin{tabular}{|l|} 
Thermally \\
Altered
\end{tabular} & \begin{tabular}{|l|} 
No stage or shape given due to \\
fragmentary nature, large flake \\
thinning along central axis, well \\
thinned along remaining lateral \\
and proximal edges, no cortex \\
remaining, evidence of battering \\
along lateral edge $(13.12 \mathrm{~mm})$, \\
evidence of utilization on \\
recurved lateral edge $(11.01 \mathrm{~mm})$ \\
on soft material for cutting \\
activities, specimen broken at \\
material flaw
\end{tabular} & 3.66 & 21.18 & 22.65 & 7.75 \\
\hline 31.2 & 57 & 1 & & 4 & & $40-50$ & & 77 & 51 & 1 & & Prehistoric & Chert & Unknown & Debitage & Tertiary Flake & Proximal Fragment & na & na & na & na & na & na \\
\hline 31.3 & 57 & 1 & & 4 & & $40-50$ & & 77 & 51 & 1 & & Prehistoric & Metaquartzite & Unknown & Debitage & \begin{tabular}{|l|} 
Secondary \\
Flake \\
\end{tabular} & Medial Fragment & $\begin{array}{l}\text { Thermally } \\
\text { Altered }\end{array}$ & na & na & na & na & na \\
\hline 31.4 & 57 & 1 & & 4 & & $40-50$ & & 77 & 51 & 1 & & Prehistoric & Chert & Unknown & Debitage & \begin{tabular}{|l|}
$\begin{array}{l}\text { Secondary } \\
\text { Flake }\end{array}$ \\
\end{tabular} & Medial Fragment & na & na & na & na & na & na \\
\hline 31.5 & 57 & 1 & & 4 & & $40-50$ & & 77 & 51 & 1 & & Prehistoric & Metaquartzite & Unknown & Debitage & Tertiary Flake & Proximal Fragment & \begin{tabular}{|l|} 
Thermally \\
Altered
\end{tabular} & na & na & na & na & na \\
\hline 31.6 & 57 & 1 & & 4 & & $40-50$ & & 77 & 51 & 1 & & Prehistoric & Metaquartzite & Unknown & Debitage & Tertiary Flake & Distal Fragment & $\begin{array}{l}\text { Thermally } \\
\text { Altered }\end{array}$ & na & na & na & na & na \\
\hline 31.7 & 57 & 1 & & 4 & & $40-50$ & & 77 & 51 & 1 & & Prehistoric & Silicified Wood & Unknown & Debitage & \begin{tabular}{|l} 
Secondary \\
Flake
\end{tabular} & Proximal Fragment & na & na & na & na & na & na \\
\hline 31.8 & 57 & 1 & & 4 & & $40-50$ & & 77 & 51 & 2 & & Prehistoric & Silicified Wood & Unknown & Debitage & \begin{tabular}{|l|} 
Secondary \\
Flake
\end{tabular} & Complete & na & na & na & na & na & na \\
\hline 31.9 & 57 & 1 & & 4 & & $40-50$ & & 77 & 51 & 1 & & Prehistoric & Silicified Wood & Unknown & Debitage & Tertiary Flake & Distal Fragment & \begin{tabular}{|l} 
Thermally \\
Altered
\end{tabular} & na & na & na & na & na \\
\hline 32.1 & 62 & 1 & & 5 & & 50-60 & & 77 & 51 & 1 & & Prehistoric & Chert & Unknown & Debitage & $\begin{array}{l}\text { Secondary } \\
\text { Flake }\end{array}$ & Distal Fragment & na & na & na & na & na & na \\
\hline 32.11 & 62 & 1 & & 5 & & $50-60$ & & 77 & 51 & 1 & & Prehistoric & Metaquartzite & Unknown & Debitage & $\begin{array}{l}\text { Secondary } \\
\text { Flake }\end{array}$ & Proximal Fragment & $\begin{array}{l}\text { Thermally } \\
\text { Altered }\end{array}$ & na & na & na & na & na \\
\hline 32.12 & 62 & 1 & & 5 & & $50-60$ & & 77 & 51 & 1 & & Prehistoric & Orthoquartzite & Unknown & Debitage & $\begin{array}{l}\text { Secondary } \\
\text { Flake }\end{array}$ & Medial Fragment & $\begin{array}{l}\text { Thermally } \\
\text { Altered }\end{array}$ & na & na & na & na & na \\
\hline 32.2 & 62 & 1 & & 5 & & $50-60$ & & 77 & 51 & 1 & & Prehistoric & Chert & Unknown & Debitage & \begin{tabular}{|l|} 
\\
Secondary \\
Flake
\end{tabular} & Distal Fragment & $\begin{array}{l}\text { Thermally } \\
\text { Altered }\end{array}$ & na & na & na & na & na \\
\hline 32.3 & 62 & 1 & & 5 & & 50-60 & & 77 & 51 & 1 & & Prehistoric & Metaquartzite & Unknown & Debitage & $\begin{array}{l}\text { Secondary } \\
\text { Flake }\end{array}$ & Medial Fragment & \begin{tabular}{|l|} 
Thermally \\
Altered
\end{tabular} & na & na & na & na & na \\
\hline 32.4 & 62 & 1 & & 5 & & $50-60$ & & 77 & 51 & 1 & & Prehistoric & Metaquartzite & Unknown & Debitage & Tertiary Flake & \begin{tabular}{|l|} 
Distal Fragment \\
\end{tabular} & $\begin{array}{l}\text { Thermally } \\
\text { Altered }\end{array}$ & na & na & na & na & na \\
\hline 32.5 & 62 & 1 & & 5 & & $\begin{array}{l}50-60 \\
\end{array}$ & & 77 & 51 & 1 & & Prehistoric & Orthoquartzite & Unknown & Debitage & Tertiary Flake & Distal Fragment & na & na & na & na & na & na \\
\hline 32.6 & 62 & 1 & & 5 & & $50-60$ & & 77 & 51 & 1 & & Prehistoric & Silicified Wood & Unknown & Debitage & \begin{tabular}{|l|}
$\begin{array}{l}\text { Secondary } \\
\text { Flake }\end{array}$ \\
\end{tabular} & Distal Fragment & na & & & & & \\
\hline 32.7 & 62 & 1 & & 5 & & $50-60$ & & 77 & 51 & 1 & & Prehistoric & Metaquartzite & Unknown & Debitage & $\begin{array}{l}\text { Secondary } \\
\text { Flake }\end{array}$ & Proximal Fragment & \begin{tabular}{|l|} 
Thermally \\
Altered
\end{tabular} & na & na & na & na & na \\
\hline 32.8 & 62 & 1 & & 5 & & $50-60$ & & 77 & 51 & 1 & & Prehistoric & Silicified Wood & Unknown & Debitage & Tertiary Flake & Complete & $\begin{array}{l}\text { Thermally } \\
\text { Altered }\end{array}$ & na & na & na & na & na \\
\hline
\end{tabular}




\begin{tabular}{|c|c|c|c|c|c|c|c|c|c|c|c|c|c|c|c|c|c|c|c|c|c|c|c|}
\hline Lot No. & FS No. & $\begin{array}{l}\text { Unit } \\
\text { No. }\end{array}$ & $\begin{array}{l}\text { ST } \\
\text { No. }\end{array}$ & Level & $\begin{array}{l}\text { Depth } \\
\text { (cmbs) }\end{array}$ & $\begin{array}{c}\text { Depth } \\
\text { (cmbd) }\end{array}$ & Provience & Northing & Easting & $\begin{array}{c}\text { No. of } \\
\text { Specimens }\end{array}$ & $\begin{array}{c}\text { Time } \\
\text { Period }\end{array}$ & Era/Phase & Artifact Material & Use Context & $\begin{array}{l}\text { Artifact } \\
\text { Description }\end{array}$ & $\begin{array}{l}\text { Artifact Sub- } \\
\text { description }\end{array}$ & $\begin{array}{c}\text { Artifact } \\
\text { Form/Condition }\end{array}$ & \begin{tabular}{|c} 
Surface \\
Treatment
\end{tabular} & Comments & $\begin{array}{l}\text { Weight in } \\
\text { grams }\end{array}$ & $\begin{array}{l}\text { Length in } \\
\mathrm{mm}\end{array}$ & $\begin{array}{l}\text { Width in } \\
\mathrm{mm}\end{array}$ & $\begin{array}{c}\text { Thickness in } \\
\mathrm{mm}\end{array}$ \\
\hline 32.9 & 62 & 1 & & 5 & & $50-60$ & & 77 & 51 & 2 & & Prehistoric & Silicified Wood & Unknown & Debitage & Tertiary Flake & Distal Fragment & $\begin{array}{l}\text { Thermally } \\
\text { Altered }\end{array}$ & na & na & na & na & na \\
\hline 33.1 & 64 & 1 & & 6 & & $\begin{array}{ll}60-70 \\
\end{array}$ & & 77 & 51 & 2 & & Prehistoric & Metaquartzite & Unknown & Debitage & \begin{tabular}{|l|} 
Secondary \\
Flake
\end{tabular} & Medial Fragment & $\begin{array}{l}\text { Thermally } \\
\text { Altered }\end{array}$ & na & na & na & na & na \\
\hline 33.2 & 64 & 1 & & 6 & & $\begin{array}{ll}60-70 \\
\end{array}$ & & 77 & 51 & 2 & & Prehistoric & Metaquartzite & Unknown & Debitage & \begin{tabular}{|l|} 
Secondary \\
Flake
\end{tabular} & Distal Fragment & $\begin{array}{l}\text { Thermally } \\
\text { Altered }\end{array}$ & na & na & na & na & na \\
\hline 33.3 & 64 & 1 & & 6 & & \begin{tabular}{|l|l|}
$60-70$ \\
\end{tabular} & & 77 & 51 & 1 & & Prehistoric & Metaquartzite & Unknown & Debitage & Tertiary Flake & Proximal Fragment & \begin{tabular}{|l|} 
Thermally \\
Altered
\end{tabular} & na & na & na & na & na \\
\hline 33.4 & 64 & 1 & & 6 & & $\begin{array}{ll}60-70 \\
\end{array}$ & & 77 & 51 & 1 & & Prehistoric & Orthoquartzite & Unknown & Debitage & Tertiary Flake & Complete & \begin{tabular}{|l} 
Thermally \\
Altered
\end{tabular} & na & na & na & na & na \\
\hline 33.5 & 64 & 1 & & 6 & & $\begin{array}{ll}60-70 \\
\end{array}$ & & 77 & 51 & 1 & & Prehistoric & Silicified Wood & Unknown & Debitage & \begin{tabular}{|l|} 
Secondary \\
Flake
\end{tabular} & Medial Fragment & \begin{tabular}{|l|} 
Thermally \\
Altered
\end{tabular} & na & na & na & na & na \\
\hline 33.6 & 64 & 1 & & 6 & & 60-70 & & 77 & 51 & 1 & & Prehistoric & Silicified Wood & Unknown & \begin{tabular}{|l|l|} 
Debitage \\
\end{tabular} & Tertiary Flake & Medial Fragment & na & na & na & na & na & na \\
\hline 33.7 & 64 & 1 & & 6 & & $\begin{array}{ll}60-70 \\
\end{array}$ & & 77 & 51 & 1 & & Prehistoric & Silicified Wood & Unknown & Debitage & Tertiary Flake & Distal Fragment & \begin{tabular}{|l|} 
Thermally \\
Altered
\end{tabular} & na & na & na & na & na \\
\hline 34.1 & 68 & 1 & & 7 & & 70-79 & & 77 & 51 & 1 & & Prehistoric & Metaquartzite & Unknown & Debitage & \begin{tabular}{|l|}
$\begin{array}{l}\text { Secondary } \\
\text { Flake }\end{array}$ \\
|lakdacory \\
\end{tabular} & Complete & \begin{tabular}{|l} 
Thermally \\
Altered
\end{tabular} & na & na & na & na & na \\
\hline 34.2 & 68 & 1 & & 7 & & \begin{tabular}{ll|}
$70-79$ \\
\end{tabular} & & 77 & 51 & 1 & & Prehistoric & Metaquartzite & Unknown & Debitage & Tertiary Flake & Medial Fragment & \begin{tabular}{|l|} 
Thermally \\
Altered
\end{tabular} & na & na & na & na & na \\
\hline 34.3 & 68 & 1 & & 7 & & \begin{tabular}{|l|}
$70-79$ \\
\end{tabular} & & 77 & 51 & 1 & & Prehistoric & Silicified Wood & Unknown & Debitage & \begin{tabular}{|l|} 
Secondary \\
Flake
\end{tabular} & Medial Fragment & \begin{tabular}{|l|}
$\begin{array}{l}\text { Thermally } \\
\text { Altered }\end{array}$ \\
\end{tabular} & na & na & na & na & na \\
\hline 34.4 & 68 & 1 & & 7 & & \begin{tabular}{|l|}
$70-79$ \\
\end{tabular} & & 77 & 51 & 2 & & Prehistoric & Silicified Wood & Unknown & Debitage & Tertiary Flake & Proximal Fragment & \begin{tabular}{|l|} 
Thermally \\
Altered
\end{tabular} & na & na & na & na & na \\
\hline 34.5 & 68 & 1 & & 7 & & 70-79 & & 77 & 51 & 1 & & Prehistoric & Silicified Wood & Unknown & Debitage & $\begin{array}{l}\text { Secondary } \\
\text { Flake }\end{array}$ & Medial Fragment & $\begin{array}{l}\text { Thermally } \\
\text { Altered }\end{array}$ & na & na & na & na & na \\
\hline 35.1 & 29 & 2 & & 2 & & 19-30 & & 77 & 49 & 1 & & Prehistoric & Chert & Unknown & Debitage & $\begin{array}{l}\text { Secondary } \\
\text { Flake } \\
\end{array}$ & \begin{tabular}{|l} 
Distal Fragment \\
\end{tabular} & na & na & na & na & na & na \\
\hline 35.2 & 29 & 2 & & 2 & & 19-30 & & 77 & 49 & 1 & & Prehistoric & Silicified Wood & Unknown & Debitage & Primary Flake & Complete & $\begin{array}{l}\text { Thermally } \\
\text { Altered }\end{array}$ & na & na & na & na & na \\
\hline 35.3 & 29 & 2 & & 2 & & 19-30 & & 77 & 49 & 1 & & Prehistoric & Silicified Wood & Unknown & Debitage & \begin{tabular}{|l|} 
Secondary \\
Flake
\end{tabular} & Complete & \begin{tabular}{|l|} 
Thermally \\
Altered
\end{tabular} & na & na & na & na & na \\
\hline 36.1 & 31 & 2 & & 3 & & $30-40$ & & 77 & 49 & 1 & & Prehistoric & Chert & Unknown & Debitage & $\begin{array}{l}\text { Secondary } \\
\text { Flake } \\
\end{array}$ & Proximal Fragment & na & na & na & na & na & na \\
\hline 36.10 & 31 & 2 & & 3 & & $30-40$ & & 77 & 49 & 2 & & \begin{tabular}{|l|} 
Prehistoric \\
\end{tabular} & Silicified Wood & Unknown & Debitage & $\begin{array}{l}\text { Secondary } \\
\text { Flake } \\
\end{array}$ & Medial Fragment & na & na & na & na & na & na \\
\hline 36.11 & 31 & 2 & & 3 & & $30-40$ & & 77 & 49 & 1 & & Prehistoric & Silicified Wood & Unknown & Debitage & $\begin{array}{l}\text { Secondary } \\
\text { Flake }\end{array}$ & Medial Fragment & \begin{tabular}{|l|}
$\begin{array}{l}\text { Thermally } \\
\text { Altered }\end{array}$ \\
\end{tabular} & na & na & na & na & na \\
\hline 36.12 & 31 & 2 & & 3 & & $30-40$ & & 77 & 49 & 1 & & Prehistoric & Silicified Wood & Unknown & \begin{tabular}{|l} 
Debitage \\
\end{tabular} & Tertiary Flake & Proximal Fragment & \begin{tabular}{|l|} 
Thermally \\
Altered
\end{tabular} & na & na & na & na & na \\
\hline 36.13 & 31 & 2 & & 3 & & $30-40$ & & 77 & 49 & 1 & & Prehistoric & Silicified Wood & Unknown & Debitage & Tertiary Flake & Medial Fragment & na & na & na & na & na & na \\
\hline 36.14 & 31 & 2 & & 3 & & $30-40$ & & 77 & 49 & 2 & & Prehistoric & Silicified Wood & Unknown & Debitage & Tertiary Flake & Distal Fragment & \begin{tabular}{|l|} 
Thermally \\
Altered
\end{tabular} & na & na & na & na & na \\
\hline 36.15 & 31 & 2 & & 3 & & $30-40$ & & 77 & 49 & 1 & & Prehistoric & Silicified Wood & Unknown & Debitage & Tertiary Flake & Proximal Fragment & na & na & na & na & na & na \\
\hline 36.16 & 31 & 2 & & 3 & & $30-40$ & & 77 & 49 & 2 & & Prehistoric & Silicified Wood & Unknown & Debitage & Tertiary Flake & Distal Fragment & na & na & na & na & 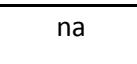 & na \\
\hline 36.17 & 31 & 2 & & 3 & & $30-40$ & & 77 & 49 & 1 & & Prehistoric & Hematitic Sandstone & Unknown & Debitage & Tertiary Flake & Medial Fragment & \begin{tabular}{|l|} 
Thermally \\
Altered
\end{tabular} & na & na & na & na & na \\
\hline
\end{tabular}




\begin{tabular}{|c|c|c|c|c|c|c|c|c|c|c|c|c|c|c|c|c|c|c|c|c|c|c|c|}
\hline Lot No. & FS No. & $\begin{array}{l}\text { Unit } \\
\text { No. }\end{array}$ & \begin{tabular}{|l|} 
ST \\
No. \\
\end{tabular} & Level & $\begin{array}{l}\text { Depth } \\
\text { (cmbs) }\end{array}$ & $\begin{array}{l}\text { Depth } \\
\text { (cmbd) }\end{array}$ & Provience & Northing & Easting & $\begin{array}{c}\begin{array}{c}\text { No. of } \\
\text { Specimens }\end{array} \\
\end{array}$ & $\begin{array}{l}\text { Time } \\
\text { Period }\end{array}$ & Era/Phase & Artifact Material & Use Context & $\begin{array}{c}\text { Artifact } \\
\text { Description }\end{array}$ & $\begin{array}{c}\text { Artifact Sub- } \\
\text { description }\end{array}$ & $\begin{array}{c}\text { Artifact } \\
\text { Form/Condition }\end{array}$ & \begin{tabular}{|c|} 
Surface \\
Treatment
\end{tabular} & Comments & $\begin{array}{c}\text { Weight in } \\
\text { grams }\end{array}$ & $\begin{array}{c}\text { Length in } \\
\mathrm{mm}\end{array}$ & $\begin{array}{c}\text { Width in } \\
\mathrm{mm}\end{array}$ & \begin{tabular}{|c|} 
Thickness in \\
$\mathrm{mm}$
\end{tabular} \\
\hline 36.18 & 31 & 2 & & 3 & & $30-40$ & & 77 & 49 & 1 & & Prehistoric & Silicified Wood & Unknown & Biface & na & Proximal Fragment & na & \begin{tabular}{|l|} 
No stage or shape given due to \\
fragmentary yature, rounded \\
proximal edge, expanding lateral \\
edges, well thinned along \\
remaining proximal and lateral \\
edges, evidence of battering along \\
proximal-lateral edge $(5.90 \mathrm{~mm})$, \\
poor quality material
\end{tabular} & 0.37 & 12.11 & 9.21 & \begin{tabular}{ll|}
3.64 \\
\end{tabular} \\
\hline 36.2 & 31 & 2 & & 3 & & $30-40$ & & 77 & 49 & 1 & & Prehistoric & Silicified Wood & Unknown & Debitage & $\begin{array}{l}\begin{array}{l}\text { Secondary } \\
\text { Flake }\end{array} \\
\end{array}$ & Distal Fragment & na & na & na & na & na & na \\
\hline \begin{tabular}{|l|}
36.3 \\
\end{tabular} & 31 & 2 & & 3 & & $30-40$ & & 77 & 49 & 3 & & Prehistoric & Metaquartzite & Unknown & Debitage & $\begin{array}{l}\begin{array}{l}\text { Secondary } \\
\text { Flake }\end{array} \\
\end{array}$ & Proximal Fragment & $\begin{array}{l}\text { Thermally } \\
\text { Altered }\end{array}$ & na & na & na & na & na \\
\hline $\begin{array}{ll}36.4 \\
\end{array}$ & 31 & 2 & & 3 & & $30-40$ & & 77 & 49 & 3 & & Prehistoric & Metaquartzite & Unknown & Debitage & Tertiary Flake & Proximal Fragment & $\begin{array}{l}\text { Thermally } \\
\text { Altered }\end{array}$ & na & na & na & na & na \\
\hline 36.5 & 31 & 2 & & 3 & & $30-40$ & & 77 & 49 & 1 & & Prehistoric & Chert & Unknown & Debitage & $\begin{array}{l}\begin{array}{l}\text { Secondary } \\
\text { Flake }\end{array} \\
\end{array}$ & \begin{tabular}{|l|} 
Distal Fragment \\
\end{tabular} & $\begin{array}{l}\text { Thermally } \\
\text { Altered }\end{array}$ & na & na & na & na & na \\
\hline \begin{tabular}{|l|l|}
36.6 \\
\end{tabular} & 31 & 2 & & 3 & & $30-40$ & & 77 & 49 & 1 & & Prehistoric & Metaquartzite & Unknown & Debitage & \begin{tabular}{|l|} 
Tertiary Flake \\
\end{tabular} & Medial Fragment & $\begin{array}{l}\text { Thermally } \\
\text { Altered }\end{array}$ & na & na & na & na & na \\
\hline $\begin{array}{l}36.7 \\
\end{array}$ & 31 & 2 & & 3 & & $30-40$ & & 77 & 49 & 1 & & Prehistoric & Metaquartzite & Unknown & Debitage & Tertiary Flake & Proximal Fragment & na & na & na & na & na & na \\
\hline $\begin{array}{ll}36.8 \\
\end{array}$ & 31 & 2 & & 3 & & $30-40$ & & 77 & 49 & 1 & & Prehistoric & Metaquartzite & Unknown & Debitage & Tertiary Flake & Medial Fragment & na & na & na & na & na & na \\
\hline \begin{tabular}{|l|}
36.9 \\
\end{tabular} & 31 & 2 & & 3 & & $30-40$ & & 77 & 49 & 1 & & Prehistoric & Silicified Wood & Unknown & Debitage & $\begin{array}{l}\begin{array}{l}\text { Secondary } \\
\text { Flake }\end{array} \\
\end{array}$ & Proximal Fragment & na & na & na & na & na & na \\
\hline \begin{tabular}{ll|}
37.1 \\
\end{tabular} & 33 & 2 & & 4 & & $40-50$ & & 77 & 49 & 1 & & Prehistoric & Chert & Unknown & Debitage & Tertiary Flake & Complete & $\begin{array}{l}\text { Thermally } \\
\text { Altered }\end{array}$ & na & na & na & na & na \\
\hline 37.10 & 33 & 2 & & 4 & & $40-50$ & & 77 & 49 & 5 & & Prehistoric & Silicified Wood & Unknown & Debitage & Tertiary Flake & Medial Fragment & na & na & na & na & na & na \\
\hline 37.11 & 33 & 2 & & 4 & & $40-50$ & & 77 & 49 & 1 & & Prehistoric & Silicified Wood & Unknown & Debitage & Tertiary Flake & Distal Fragment & $\begin{array}{l}\text { Thermally } \\
\text { Altered }\end{array}$ & na & na & na & na & na \\
\hline 37.12 & 33 & 2 & & 4 & & $40-50$ & & 77 & 49 & 1 & & Prehistoric & Chert & Unknown & Debitage & Tertiary Flake & Medial Fragment & $\begin{array}{l}\text { Thermally } \\
\text { Altered }\end{array}$ & na & na & na & na & na \\
\hline 37.2 & 33 & 2 & & 4 & & $40-50$ & & 77 & 49 & 1 & & Prehistoric & Metaquartzite & Unknown & Debitage & Primary Flake & Proximal Fragment & $\begin{array}{l}\text { Thermally } \\
\text { Altered }\end{array}$ & na & na & na & na & na \\
\hline \begin{tabular}{|l|}
37.3 \\
\end{tabular} & 33 & 2 & & 4 & & $40-50$ & & 77 & 49 & 1 & & Prehistoric & Orthoquartzite & Unknown & Debitage & $\begin{array}{l}\text { Secondary } \\
\text { Flake }\end{array}$ & Distal Fragment & $\begin{array}{l}\text { Thermally } \\
\text { Altered }\end{array}$ & na & na & na & na & na \\
\hline $\begin{array}{ll}37.4 \\
\end{array}$ & 33 & 2 & & 4 & & $40-50$ & & 77 & 49 & 1 & & Prehistoric & Metaquartzite & Unknown & Debitage & Tertiary Flake & Distal Fragment & na & na & na & na & na & na \\
\hline \begin{tabular}{ll|}
37.5 \\
\end{tabular} & 33 & 2 & & 4 & & $40-50$ & & 77 & 49 & 1 & & Prehistoric & Silicified Wood & Unknown & Debitage & $\begin{array}{l}\text { Secondary } \\
\text { Flake }\end{array}$ & Proximal Fragment & na & na & na & na & na & na \\
\hline 37.6 & 33 & 2 & & 4 & & $40-50$ & & 77 & 49 & 2 & & Prehistoric & Silicified Wood & Unknown & Debitage & $\begin{array}{l}\text { Secondary } \\
\text { Flake }\end{array}$ & Proximal Fragment & $\begin{array}{l}\text { Thermally } \\
\text { Altered }\end{array}$ & na & na & na & na & na \\
\hline 37.7 & 33 & 2 & & 4 & & $40-50$ & & 77 & 49 & 1 & & Prehistoric & Silicified Wood & Unknown & Debitage & $\begin{array}{l}\text { Secondary } \\
\text { Flake }\end{array}$ & Distal Fragment & $\begin{array}{l}\text { Thermally } \\
\text { Altered }\end{array}$ & na & na & na & na & na \\
\hline \begin{tabular}{ll|}
37.8 \\
\end{tabular} & 33 & 2 & & 4 & & $40-50$ & & 77 & 49 & 1 & & Prehistoric & Silicified Wood & Unknown & Debitage & $\begin{array}{l}\text { Secondary } \\
\text { Flake }\end{array}$ & Distal Fragment & na & na & na & na & na & na \\
\hline \begin{tabular}{|l|}
37.9 \\
\end{tabular} & 33 & 2 & & 4 & & $40-50$ & & 77 & 49 & 1 & & Prehistoric & Silicified Wood & Unknown & Debitage & Tertiary Flake & Medial Fragment & $\begin{array}{l}\text { Thermally } \\
\text { Altered }\end{array}$ & na & na & na & na & na \\
\hline 38.1 & 42 & 2 & & 5 & & 50-60 & & 77 & 49 & 1 & & Prehistoric & Chert & Unknown & Debitage & Primary Flake & Complete & na & na & na & na & na & na \\
\hline 38.2 & 42 & 2 & & 5 & & $50-60$ & & 77 & 49 & 1 & & Prehistoric & Silicified Wood & Unknown & Debitage & \begin{tabular}{|l|} 
Secondary \\
Flake
\end{tabular} & Complete & na & na & na & na & na & na \\
\hline
\end{tabular}




\begin{tabular}{|c|c|c|c|c|c|c|c|c|c|c|c|c|c|c|c|c|c|c|c|c|c|c|c|}
\hline L L No. & FS No. & $\begin{array}{l}\text { Unit } \\
\text { No. }\end{array}$ & \begin{tabular}{|l|} 
ST \\
No. \\
\end{tabular} & Level & $\begin{array}{c}\text { Depth } \\
\text { (cmbs) }\end{array}$ & $\begin{array}{l}\text { Depth } \\
\text { (cmbd) }\end{array}$ & Provience & Northing & Easting & $\begin{array}{c}\text { No. of } \\
\text { Specimens }\end{array}$ & $\begin{array}{l}\text { Time } \\
\text { Period }\end{array}$ & Era/Phase & Artifact Material & Use Context & $\begin{array}{c}\text { Artifact } \\
\text { Description }\end{array}$ & $\begin{array}{l}\text { Artifact Sub- } \\
\text { description }\end{array}$ & $\begin{array}{c}\text { Artifact } \\
\text { Form/Condition }\end{array}$ & \begin{tabular}{|c|} 
Surface \\
Treatment \\
\end{tabular} & Comments & $\begin{array}{l}\text { Weight in } \\
\text { grams }\end{array}$ & $\begin{array}{l}\text { Length in } \\
\mathrm{mm}\end{array}$ & $\begin{array}{c}\text { Width in } \\
\mathrm{mm}\end{array}$ & $\begin{array}{c}\text { Thickness in } \\
\mathrm{mm}\end{array}$ \\
\hline 38.3 & 42 & 2 & & 5 & & 50-60 & & 77 & 49 & 1 & & Prehistoric & Chert & Unknown & Debitage & Tertiary Flake & Proximal Fragment & na & na & na & na & na & na \\
\hline 38.4 & 42 & 2 & & 5 & & 50-60 & & 77 & 49 & 1 & & Prehistoric & Metaquartzite & Unknown & Debitage & Tertiary Flake & Medial Fragment & $\begin{array}{l}\text { Thermally } \\
\text { Altered }\end{array}$ & na & na & na & na & na \\
\hline 38.5 & 42 & 2 & & 5 & & 50-60 & & 77 & 49 & 1 & & Prehistoric & Silicified Wood & |Unknown & \begin{tabular}{|l|l|} 
Debitage \\
\end{tabular} & Primary Flake & Proximal Fragment & na & na & na & na & na & na \\
\hline 38.6 & 42 & 2 & & 5 & & $50-60$ & & 77 & 49 & 1 & & Prehistoric & Silicified Wood & Unknown & Debitage & $\begin{array}{l}\text { Secondary } \\
\text { Flake }\end{array}$ & Medial Fragment & \begin{tabular}{|l} 
Thermally \\
Altered
\end{tabular} & na & na & na & na & na \\
\hline 38.7 & 42 & 2 & & 5 & & 50-60 & & 77 & 49 & 1 & & Prehistoric & Silicified Wood & Unknown & Debitage & \begin{tabular}{|l|} 
Secondary \\
Flake
\end{tabular} & Proximal Fragment & na & na & na & na & na & na \\
\hline 38.8 & 42 & 2 & & 5 & & 50-60 & & 77 & 49 & 1 & & Prehistoric & Silicified Wood & Unknown & Debitage & Tertiary Flake & Distal Fragment & $\begin{array}{l}\text { Thermally } \\
\text { Altered }\end{array}$ & na & na & na & na & na \\
\hline 39.1 & 46 & 2 & & 6 & & $60-70$ & & 77 & 49 & 1 & & Prehistoric & Chert & |Unknown & Debitage & \begin{tabular}{|l} 
Secondary \\
Flake
\end{tabular} & Distal Fragment & \begin{tabular}{|l} 
Thermally \\
Altered
\end{tabular} & na & na & na & na & na \\
\hline 39.10 & 46 & 2 & & 6 & & $\begin{array}{c}60-70 \\
\end{array}$ & & 77 & 49 & 1 & & Prehistoric & Silicified Wood & Unknown & Debitage & $\begin{array}{l}\text { Secondary } \\
\text { Flake }\end{array}$ & Medial Fragment & na & na & na & na & na & na \\
\hline 39.11 & 46 & 2 & & 6 & & $\begin{array}{l}60-70 \\
\end{array}$ & & 77 & 49 & 1 & & Prehistoric & Silicified Wood & Unknown & Debitage & $\begin{array}{l}\begin{array}{l}\text { Secondary } \\
\text { Flake }\end{array} \\
\end{array}$ & Proximal Fragment & na & na & na & na & na & na \\
\hline 39.2 & 46 & 2 & & 6 & & $\begin{array}{l}60-70 \\
\end{array}$ & & 77 & 49 & 1 & & \begin{tabular}{|l|l|} 
Prehistoric \\
\end{tabular} & Chert & Unknown & Debitage & Tertiary Flake & Complete & na & na & na & na & na & na \\
\hline 39.3 & 46 & 2 & & 6 & & $60-70$ & & 77 & 49 & 1 & & Prehistoric & Silicified Wood & Unknown & Debitage & \begin{tabular}{|l|} 
Tertiary Flake \\
\end{tabular} & Distal Fragment & \begin{tabular}{|l} 
Thermally \\
Altered
\end{tabular} & na & na & na & na & na \\
\hline 39.4 & 46 & 2 & & 6 & & $60-70$ & & 77 & 49 & 1 & & \begin{tabular}{|l} 
Prehistoric \\
\end{tabular} & Chert & Unknown & Debitage & Tertiary Flake & Complete & na & na & na & na & na & na \\
\hline 39.5 & 46 & 2 & & 6 & & $60-70$ & & 77 & 49 & 1 & & Prehistoric & Metaquartzite & Unknown & Debitage & \begin{tabular}{|l|} 
Primary Flake \\
\end{tabular} & Medial Fragment & $\begin{array}{l}\text { Thermally } \\
\text { Altered }\end{array}$ & na & na & na & na & na \\
\hline 39.6 & 46 & 2 & & 6 & & $\begin{array}{l}60-70 \\
\end{array}$ & & 77 & 49 & 1 & & Prehistoric & Metaquartzite & Unknown & Debitage & $\begin{array}{l}\text { Secondary } \\
\text { Flake }\end{array}$ & Medial Fragment & $\begin{array}{l}\text { Thermally } \\
\text { Altered }\end{array}$ & na & na & na & na & na \\
\hline 39.7 & 46 & 2 & & 6 & & $60-70$ & & 77 & 49 & 1 & & Prehistoric & Metaquartzite & Unknown & Debitage & $\begin{array}{l}\text { Secondary } \\
\text { Flake }\end{array}$ & Distal Fragment & $\begin{array}{l}\text { Thermally } \\
\text { Altered }\end{array}$ & na & na & na & na & na \\
\hline $\begin{array}{ll}39.8 \\
\end{array}$ & 46 & 2 & & 6 & & $60-70$ & & 77 & 49 & 1 & & Prehistoric & Metaquartzite & Unknown & Debitage & Tertiary Flake & Distal Fragment & $\begin{array}{l}\text { Thermally } \\
\text { Altered }\end{array}$ & na & na & na & na & na \\
\hline 39.9 & 46 & 2 & & 6 & & $60-70$ & & 77 & 49 & 1 & & \begin{tabular}{|l} 
Prehistoric \\
\end{tabular} & Silicified Wood & Unknown & Debitage & Tertiary Flake & Complete & na & na & na & na & na & na \\
\hline 40.1 & 103 & 2 & & 7 & & 70-80 & & 77 & 49 & 1 & & Prehistoric & Chert & Unknown & Debitage & $\begin{array}{l}\text { Secondary } \\
\text { Flake }\end{array}$ & Medial Fragment & na & na & na & na & na & na \\
\hline 40.10 & 103 & 2 & & 7 & & 70-80 & & 77 & 49 & 1 & & Prehistoric & Silicified Wood & Unknown & Debitage & $\begin{array}{l}\text { Secondary } \\
\text { Flake }\end{array}$ & Distal Fragment & na & na & na & na & na & na \\
\hline 40.11 & 103 & 2 & & 7 & & 70-80 & & 77 & 49 & 1 & & Prehistoric & Silicified Wood & Unknown & Debitage & Tertiary Flake & Distal Fragment & \begin{tabular}{|l|} 
Thermally \\
Altered
\end{tabular} & na & na & na & na & na \\
\hline 40.2 & 103 & 2 & & 7 & & \begin{tabular}{|l|}
$70-80$ \\
\end{tabular} & & 77 & 49 & 1 & & Prehistoric & Silicified Wood & Unknown & Debitage & \begin{tabular}{|l|} 
Tertiary Flake \\
\end{tabular} & Distal Fragment & na & na & na & na & na & na \\
\hline 40.3 & 103 & 2 & & 7 & & 70-80 & & 77 & 49 & 1 & & Prehistoric & Metaquartzite & Unknown & Debitage & Primary Flake & Complete & \begin{tabular}{|l} 
Thermally \\
Altered
\end{tabular} & na & na & na & na & na \\
\hline 40.4 & 103 & 2 & & 7 & & 70-80 & & 77 & 49 & 2 & & Prehistoric & Metaquartzite & Unknown & Debitage & $\begin{array}{l}\text { Secondary } \\
\text { Flake }\end{array}$ & Proximal Fragment & \begin{tabular}{|l} 
Thermally \\
Altered
\end{tabular} & na & na & na & na & na \\
\hline 40.5 & 103 & 2 & & 7 & & $70-80$ & & 77 & 49 & 2 & & Prehistoric & Metaquartzite & Unknown & Debitage & \begin{tabular}{|l|} 
Secondary \\
Flake
\end{tabular} & Medial Fragment & \begin{tabular}{|l|} 
Thermally \\
Altered
\end{tabular} & na & na & na & na & na \\
\hline 40.6 & 103 & 2 & & 7 & & 70-80 & & 77 & 49 & 1 & & Prehistoric & Metaquartzite & Unknown & Debitage & Tertiary Flake & Medial Fragment & $\begin{array}{l}\text { Thermally } \\
\text { Altered }\end{array}$ & na & na & na & na & na \\
\hline 40.7 & 103 & 2 & & 7 & & 70-80 & & 77 & 49 & 1 & & Prehistoric & Silicified Wood & Unknown & Debitage & $\begin{array}{l}\text { Secondary } \\
\text { Flake }\end{array}$ & Proximal Fragment & na & na & na & na & na & na \\
\hline 40.8 & 103 & 2 & & 7 & & $70-80$ & & 77 & 49 & 1 & & Prehistoric & Metaquartzite & |Unknown & Debitage & $\begin{array}{l}\text { Secondary } \\
\text { Flake }\end{array}$ & Proximal Fragment & na & na & na & na & na & na \\
\hline
\end{tabular}




\begin{tabular}{|c|c|c|c|c|c|c|c|c|c|c|c|c|c|c|c|c|c|c|c|c|c|c|c|}
\hline Lot No. & FS No. & $\begin{array}{l}\text { Unit } \\
\text { No. }\end{array}$ & \begin{tabular}{|l|} 
ST \\
No. \\
\end{tabular} & Level & \begin{tabular}{|l|} 
Depth \\
(cmbs)
\end{tabular} & $\begin{array}{l}\text { Depth } \\
\text { (cmbd) }\end{array}$ & Provience & Northing & Easting & $\begin{array}{c}\text { No. of } \\
\text { Specimens }\end{array}$ & $\begin{array}{c}\text { Time } \\
\text { Period }\end{array}$ & Era/Phase & Artifact Material & Use Context & $\begin{array}{c}\text { Artifact } \\
\text { Description }\end{array}$ & $\begin{array}{c}\text { Artifact Sub- } \\
\text { description }\end{array}$ & $\begin{array}{c}\text { Artifact } \\
\text { Form/Condition }\end{array}$ & \begin{tabular}{|c} 
Surface \\
Treatment
\end{tabular} & Comments & $\begin{array}{c}\text { Weight in } \\
\text { grams }\end{array}$ & $\begin{array}{l}\text { Length in } \\
\mathrm{mm}\end{array}$ & $\begin{array}{c}\text { Width in } \\
\mathrm{mm}\end{array}$ & $\begin{array}{c}\text { Thickness in } \\
\mathrm{mm}\end{array}$ \\
\hline 40.9 & 103 & 2 & & 7 & & $70-80$ & & 77 & 49 & 1 & & Prehistoric & Silicified Wood & Unknown & Debitage & \begin{tabular}{l|} 
Secondary \\
Flake
\end{tabular} & Medial Fragment & na & na & na & na & na & na \\
\hline 43.1 & 28 & 3 & & 2 & & $19-30$ & & 76 & 50 & 1 & & Prehistoric & Chert & Unknown & Debitage & $\begin{array}{l}\text { Secondary } \\
\text { Flake }\end{array}$ & Distal Fragment & \begin{tabular}{|l|} 
Thermally \\
Altered
\end{tabular} & na & na & na & na & na \\
\hline 43.2 & 28 & 3 & & 2 & & $19-30$ & & 76 & 50 & 2 & & Prehistoric & Metaquartzite & Unknown & Debitage & $\begin{array}{l}\text { Secondary } \\
\text { Flake }\end{array}$ & Distal Fragment & \begin{tabular}{|l|} 
Thermally \\
Altered
\end{tabular} & na & na & na & na & na \\
\hline 43.3 & 28 & 3 & & 2 & & $19-30$ & & 76 & 50 & 1 & & Prehistoric & Silicified Wood & Unknown & Debitage & $\begin{array}{l}\text { Secondary } \\
\text { Flake }\end{array}$ & \begin{tabular}{|l|} 
Proximal Fragment \\
\end{tabular} & na & na & na & na & na & na \\
\hline 43.4 & 28 & 3 & & 2 & & $19-30$ & & 76 & 50 & 1 & & Prehistoric & Silicified Wood & Unknown & Debitage & $\begin{array}{l}\text { Secondary } \\
\text { Flake }\end{array}$ & Complete & $\begin{array}{l}\text { Thermally } \\
\text { Altered }\end{array}$ & na & na & na & na & na \\
\hline 43.5 & 28 & 3 & & 2 & & $\begin{array}{l}19-30 \\
\end{array}$ & & 76 & 50 & 1 & & Prehistoric & Silicified Wood & Unknown & Debitage & Tertiary Flake & Distal Fragment & na & na & na & na & na & na \\
\hline 43.6 & 28 & 3 & & 2 & & $19-30$ & & 76 & 50 & 1 & & Prehistoric & Silicified Wood & Unknown & Debitage & Tertiary Flake & Proximal Fragment & na & na & na & na & na & na \\
\hline 43.7 & 28 & 3 & & 2 & & $19-30$ & & 76 & 50 & 1 & & Prehistoric & Silicifified Wood & Unknown & Debitage & Tertiary Flake & Proximal Fragment & \begin{tabular}{|l|} 
Thermally \\
Altered
\end{tabular} & na & na & na & na & na \\
\hline 43.8 & 28 & 3 & & 2 & & $19-30$ & & 76 & 50 & 1 & & Prehistoric & Silicified Wood & Unknown & Debitage & Tertiary Flake & Medial Fragment & na & na & na & na & na & na \\
\hline 43.9 & 28 & 3 & & 2 & & $19-30$ & & 76 & 50 & 1 & & Prehistoric & Orthoquartzite & Unknown & Debitage & \begin{tabular}{|l|} 
Secondary \\
Flake
\end{tabular} & Distal Fragment & \begin{tabular}{|l|} 
Thermally \\
Altered
\end{tabular} & na & na & na & na & na \\
\hline 45.1 & 30 & 3 & & 3 & & $30-40$ & & 76 & 50 & 1 & & Prehistoric & Chert & Unknown & Debitage & Tertiary Flake & Distal Fragment & na & na & na & na & na & na \\
\hline 45.2 & 30 & 3 & & 3 & & $30-40$ & & 76 & 50 & 1 & & Prehistoric & Chert & Unknown & Debitage & Tertiary Flake & Complete & \begin{tabular}{|l} 
Thermally \\
Altered
\end{tabular} & na & na & na & na & na \\
\hline 45.3 & 30 & 3 & & 3 & & $30-40$ & & 76 & 50 & 3 & & Prehistoric & Metaquartzite & Unknown & Debitage & \begin{tabular}{|l|} 
\\
Secondary \\
Flake
\end{tabular} & 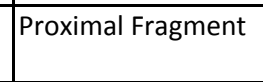 & \begin{tabular}{|l|} 
Thermally \\
Altered
\end{tabular} & na & na & na & na & na \\
\hline 45.5 & 30 & 3 & & 3 & & $30-40$ & & 76 & 50 & 1 & & Prehistoric & Metaquartzite & Unknown & Debitage & Tertiary Flake & Medial Fragment & \begin{tabular}{|l} 
Thermally \\
Altered
\end{tabular} & na & na & na & na & na \\
\hline 45.6 & 30 & 3 & & 3 & & $30-40$ & & 76 & 50 & 3 & & Prehistoric & Metaquartzite & Unknown & Debitage & Tertiary Flake & Distal Fragment & \begin{tabular}{|l} 
Thermally \\
Altered
\end{tabular} & na & na & na & na & na \\
\hline 45.7 & 30 & 3 & & 3 & & $30-40$ & & 76 & 50 & 1 & & Prehistoric & \begin{tabular}{|l} 
Orthoquartzite \\
\end{tabular} & Unknown & Debitage & Tertiary Flake & Medial Fragment & \begin{tabular}{|l} 
Thermally \\
Altered
\end{tabular} & na & na & na & na & na \\
\hline 45.8 & 30 & 3 & & 3 & & $30-40$ & & 76 & 50 & 3 & & Prehistoric & Silicified Wood & Unknown & Debitage & Tertiary Flake & Distal Fragment & \begin{tabular}{|l|} 
Thermally \\
Altered
\end{tabular} & na & na & na & na & na \\
\hline 45.9 & 30 & 3 & & 3 & & $30-40$ & & 76 & 50 & 1 & & Prehistoric & Silicified Wood & Unknown & Debitage & $\begin{array}{l}\text { Secondary } \\
\text { Flake }\end{array}$ & Complete & na & na & na & na & na & na \\
\hline 47.1 & 32 & 3 & & 4 & & $40-50$ & & 76 & 50 & 1 & & Prehistoric & Chert & Unknown & Debitage & $\begin{array}{l}\text { Secondary } \\
\text { Flake }\end{array}$ & \begin{tabular}{|l|} 
Complete \\
\end{tabular} & na & na & na & na & na & na \\
\hline 47.10 & 32 & 3 & & 4 & & $40-50$ & & 76 & 50 & 1 & & Prehistoric & Silicified Wood & Unknown & Debitage & $\begin{array}{l}\text { Secondary } \\
\text { Flake }\end{array}$ & \begin{tabular}{|c|} 
Complete \\
\end{tabular} & na & na & na & na & na & na \\
\hline 47.11 & 32 & 3 & & 4 & & $40-50$ & & 76 & 50 & 2 & & Prehistoric & Silicified Wood & Unknown & Debitage & Tertiary Flake & Proximal Fragment & na & na & na & na & na & na \\
\hline 47.12 & 32 & 3 & & 4 & & $40-50$ & & 76 & 50 & 1 & & Prehistoric & Silicified Wood & Unknown & Debitage & Tertiary Flake & Medial Fragment & na & na & na & na & na & na \\
\hline 47.13 & 32 & 3 & & 4 & & $40-50$ & & 76 & 50 & 3 & & Prehistoric & Silicified Wood & Unknown & Debitage & Tertiary Flake & Distal Fragment & na & na & na & na & na & na \\
\hline 47.14 & 32 & 3 & & 4 & & $40-50$ & & 76 & 50 & 1 & & Prehistoric & Hematitic Sandstone & Unknown & Debitage & \begin{tabular}{|l} 
Secondary \\
Flake
\end{tabular} & Medial Fragment & \begin{tabular}{|l} 
Thermally \\
Altered
\end{tabular} & na & na & na & na & na \\
\hline 47.2 & 32 & 3 & & 4 & & $40-50$ & & 76 & 50 & 1 & & Prehistoric & Metaquartzite & Unknown & Debitage & $\begin{array}{l}\text { Secondary } \\
\text { Flake }\end{array}$ & Proximal Fragment & \begin{tabular}{|l} 
Thermally \\
Altered
\end{tabular} & na & na & na & na & na \\
\hline 47.3 & 32 & 3 & & 4 & & $40-50$ & & 76 & 50 & 1 & & Prehistoric & Metaquartzite & Unknown & Debitage & $\begin{array}{l}\text { Secondary } \\
\text { Flake }\end{array}$ & Distal Fragment & \begin{tabular}{|l} 
Thermally \\
Altered
\end{tabular} & na & na & na & na & na \\
\hline 47.4 & 32 & 3 & & 4 & & $40-50$ & & 76 & 50 & 1 & & Prehistoric & Metaquartzite & Unknown & Debitage & Tertiary Flake & Medial Fragment & na & na & na & na & na & na \\
\hline
\end{tabular}




\begin{tabular}{|c|c|c|c|c|c|c|c|c|c|c|c|c|c|c|c|c|c|c|c|c|c|c|c|}
\hline Lot No. & FS No. & $\begin{array}{l}\text { Unit } \\
\text { No. }\end{array}$ & \begin{tabular}{|l|} 
ST \\
No. \\
\end{tabular} & Level & \begin{tabular}{|l} 
Depth \\
(cmbs) \\
\end{tabular} & $\begin{array}{l}\text { Depth } \\
\text { (cmbd) }\end{array}$ & Provience & Northing & Easting & $\begin{array}{c}\text { No. of } \\
\text { Specimens }\end{array}$ & $\begin{array}{c}\text { Time } \\
\text { Period }\end{array}$ & Era/Phase & Artifact Material & Use Context & $\begin{array}{c}\text { Artifact } \\
\text { Description }\end{array}$ & $\begin{array}{l}\text { Artifact Sub- } \\
\text { description }\end{array}$ & $\begin{array}{c}\text { Artifact } \\
\text { Form/Condition }\end{array}$ & $\begin{array}{c}\text { Surface } \\
\text { Treatment }\end{array}$ & Comments & $\begin{array}{l}\text { Weight in } \\
\text { grams }\end{array}$ & $\begin{array}{c}\text { Length in } \\
\mathrm{mm}\end{array}$ & $\begin{array}{c}\text { Width in } \\
\mathrm{mm}\end{array}$ & $\begin{array}{c}\text { Thickness in } \\
\mathrm{mm}\end{array}$ \\
\hline 47.5 & 32 & 3 & & \begin{tabular}{|l|}
4 \\
\end{tabular} & & $40-50$ & & 76 & 50 & 1 & & Prehistoric & Metaquartzite & Unknown & Debitage & Tertiary Flake & \begin{tabular}{|l|} 
Complete \\
\end{tabular} & \begin{tabular}{|l|} 
Thermally \\
Altered
\end{tabular} & na & na & na & na & na \\
\hline 47.6 & 32 & 3 & & 4 & & $40-50$ & & 76 & 50 & 1 & & Prehistoric & Metaquartzite & Unknown & Debitage & Tertiary Flake & Distal Fragment & na & na & na & na & na & na \\
\hline 47.7 & 32 & 3 & & 4 & & $40-50$ & & 76 & 50 & 1 & & Prehistoric & Metaquartzite & Unknown & Debitage & Tertiary Flake & \begin{tabular}{|l|} 
Proximal Fragment \\
\end{tabular} & na & na & na & na & na & na \\
\hline 47.8 & 32 & 3 & & 4 & & $40-50$ & & 76 & 50 & 1 & & Prehistoric & silicified Wood & Unknown & Debitage & Tertiary Flake & Proximal Fragment & \begin{tabular}{|l|} 
Thermally \\
Altered
\end{tabular} & na & na & na & na & na \\
\hline 47.9 & 32 & 3 & & 4 & & $40-50$ & & 76 & 50 & 3 & & Prehistoric & \begin{tabular}{|l|} 
Silicified Wood \\
\end{tabular} & Unknown & Debitage & $\begin{array}{l}\text { Secondary } \\
\text { Flake }\end{array}$ & Distal Fragment & na & na & na & na & na & na \\
\hline 49.1 & 34 & 3 & & 5 & & $50-60$ & & 76 & 50 & 1 & & Prehistoric & Chert & Unknown & Debitage & $\begin{array}{l}\text { Secondary } \\
\text { Flake }\end{array}$ & Complete & \begin{tabular}{|l|}
$\begin{array}{l}\text { Thermally } \\
\text { Altered }\end{array}$ \\
\end{tabular} & na & na & na & na & na \\
\hline 49.2 & 34 & 3 & & 5 & & $50-60$ & & 76 & 50 & 1 & & Prehistoric & Chert & Unknown & Debitage & Tertiary Flake & Medial Fragment & \begin{tabular}{|l|}
$\begin{array}{l}\text { Thermally } \\
\text { Altered }\end{array}$ \\
\end{tabular} & na & na & na & na & na \\
\hline 49.3 & 34 & 3 & & 5 & & $50-60$ & & 76 & 50 & 1 & & Prehistoric & Metaquartzite & Unknown & Debitage & Chip & Corticated & $\begin{array}{l}\text { Thermally } \\
\text { Altered }\end{array}$ & na & na & na & na & na \\
\hline $\begin{array}{ll}49.4 \\
\end{array}$ & 34 & 3 & & 5 & & $50-60$ & & 76 & 50 & 2 & & Prehistoric & Metaquartzite & Unknown & Debitage & Tertiary Flake & 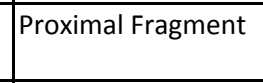 & \begin{tabular}{|l|}
$\begin{array}{l}\text { Thermally } \\
\text { Altered }\end{array}$ \\
\end{tabular} & na & na & na & na & na \\
\hline 49.5 & 34 & 3 & & 5 & & $50-60$ & & 76 & 50 & 1 & & Prehistoric & Silicified Wood & Unknown & Debitage & $\begin{array}{l}\text { Secondary } \\
\text { Flake }\end{array}$ & Complete & na & na & na & na & na & na \\
\hline 51.1 & 47 & 3 & & 6 & & $60-70$ & & 76 & 50 & 1 & & Prehistoric & Silicified Wood & Unknown & Debitage & $\begin{array}{l}\text { Secondary } \\
\text { Flake }\end{array}$ & Complete & na & na & na & na & na & na \\
\hline 51.10 & 47 & 3 & & 6 & & $60-70$ & & 76 & 50 & 1 & & Prehistoric & Chert & Unknown & Debitage & $\begin{array}{l}\text { Secondary } \\
\text { Flake }\end{array}$ & \begin{tabular}{|l} 
Proximal Fragment \\
\end{tabular} & na & na & na & na & na & na \\
\hline 51.11 & 47 & 3 & & 6 & & $60-70$ & & 76 & 50 & 1 & & Prehistoric & Silicified Wood & Unknown & Debitage & $\begin{array}{l}\text { Secondary } \\
\text { Flake }\end{array}$ & \begin{tabular}{|l} 
Proximal Fragment \\
\end{tabular} & \begin{tabular}{|l|}
$\begin{array}{l}\text { Thermally } \\
\text { Altered }\end{array}$ \\
\end{tabular} & na & na & na & na & na \\
\hline 51.13 & 47 & 3 & & 6 & & $60-70$ & & 76 & 50 & 2 & & Prehistoric & Silicified Wood & Unknown & Debitage & Tertiary Flake & Medial Fragment & na & na & na & $\mathrm{na}$ & $\mathrm{na}$ & na \\
\hline 51.14 & 47 & 3 & & 6 & & $60-70$ & & 76 & 50 & 2 & & Prehistoric & Silicified Wood & Unknown & Debitage & Tertiary Flake & Medial Fragment & na & na & na & na & na & na \\
\hline 51.15 & 47 & 3 & & 6 & & $60-70$ & & 76 & 50 & 2 & & Prehistoric & Silicified Wood & Unknown & Debitage & Tertiary Flake & Distal Fragment & na & na & na & na & na & na \\
\hline 51.16 & 47 & 3 & & 6 & & $60-70$ & & 76 & 50 & 1 & & Prehistoric & Hematitic Sandstone & Unknown & Debitage & $\begin{array}{l}\text { Secondary } \\
\text { Flake }\end{array}$ & Distal Fragment & na & na & na & na & na & na \\
\hline 51.18 & 48 & 3 & & 6 & & $60-70$ & & 76 & 50 & 1 & & Prehistoric & Metaquartzite & Unknown & Debitage & Tertiary Flake & \begin{tabular}{|l} 
Proximal Fragment \\
\end{tabular} & \begin{tabular}{|l|}
$\begin{array}{l}\text { Thermally } \\
\text { Altered }\end{array}$ \\
\end{tabular} & na & na & na & na & na \\
\hline 51.19 & 48 & 3 & & 6 & & $60-70$ & & 76 & 50 & 1 & & Prehistoric & Orthoquartzite & Unknown & Debitage & Tertiary Flake & Medial Fragment & $\begin{array}{l}\text { Thermally } \\
\text { Altered }\end{array}$ & na & na & na & na & na \\
\hline 51.2 & 47 & 3 & & 6 & & $60-70$ & & 76 & 50 & 1 & & Prehistoric & Chert & Unknown & Debitage & $\begin{array}{l}\text { Secondary } \\
\text { Flake }\end{array}$ & Proximal Fragment & \begin{tabular}{|l}
$\begin{array}{l}\text { Thermally } \\
\text { Altered }\end{array}$ \\
\end{tabular} & na & na & na & na & na \\
\hline 51.3 & 47 & 3 & & 6 & & $60-70$ & & 76 & 50 & 1 & & Prehistoric & Chert & Unknown & Debitage & Tertiary Flake & Distal Fragment & na & na & na & na & na & na \\
\hline 51.4 & 47 & 3 & & 6 & & $60-70$ & & 76 & 50 & 1 & & Prehistoric & Chert & Unknown & Debitage & Tertiary Flake & 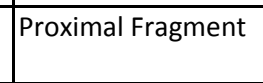 & \begin{tabular}{|l|}
$\begin{array}{l}\text { Thermally } \\
\text { Altered }\end{array}$ \\
\end{tabular} & na & na & na & na & na \\
\hline 51.5 & 47 & 3 & & 6 & & $60-70$ & & 76 & 50 & 1 & & Prehistoric & Chert & Unknown & Debitage & Tertiary Flake & Medial Fragment & $\begin{array}{l}\text { Thermally } \\
\text { Altered }\end{array}$ & na & na & na & na & na \\
\hline 51.6 & 47 & 3 & & 6 & & $60-70$ & & 76 & 50 & 2 & & Prehistoric & Metaquartzite & Unknown & Debitage & $\begin{array}{l}\text { Secondary } \\
\text { Flake }\end{array}$ & Medial Fragment & \begin{tabular}{|l|} 
Thermally \\
Altered
\end{tabular} & na & na & na & na & na \\
\hline 51.7 & 47 & 3 & & 6 & & $260-70$ & & 76 & 50 & 1 & & Prehistoric & Metaquartzite & Unknown & Debitage & Tertiary Flake & Distal Fragment & $\begin{array}{l}\text { Thermally } \\
\text { Altered } \\
\end{array}$ & na & na & na & na & na \\
\hline 51.8 & 47 & 3 & & 6 & & $60-70$ & & 76 & 50 & 2 & & Prehistoric & Metaquartzite & Unknown & Debitage & Tertiary Flake & Medial Fragment & \begin{tabular}{|l|}
$\begin{array}{l}\text { Thermally } \\
\text { Altered }\end{array}$ \\
\end{tabular} & na & na & na & na & na \\
\hline 51.9 & 47 & 3 & & 6 & & $60-70$ & & 76 & 50 & 1 & & Prehistoric & Silicified Wood & Unknown & Debitage & $\begin{array}{l}\text { Secondary } \\
\text { Flake }\end{array}$ & Proximal Fragment & na & na & na & na & na & na \\
\hline
\end{tabular}




\begin{tabular}{|c|c|c|c|c|c|c|c|c|c|c|c|c|c|c|c|c|c|c|c|c|c|c|c|}
\hline Lot No. & FS No. & $\begin{array}{l}\text { Unit } \\
\text { No. }\end{array}$ & \begin{tabular}{|l|} 
ST \\
No. \\
\end{tabular} & Level & $\begin{array}{c}\text { Depth } \\
\text { (cmbs) }\end{array}$ & $\begin{array}{l}\text { Depth } \\
\text { (cmbd) }\end{array}$ & Provience & Northing & Easting & $\begin{array}{c}\text { No. of } \\
\text { Specimens }\end{array}$ & $\begin{array}{l}\text { Time } \\
\text { Period }\end{array}$ & Era/Phase & Artifact Material & Use Context & $\begin{array}{c}\text { Artifact } \\
\text { Description }\end{array}$ & $\begin{array}{l}\text { Artifact Sub- } \\
\text { description }\end{array}$ & $\begin{array}{l}\text { Artifact } \\
\text { Form/Condition }\end{array}$ & \begin{tabular}{|c} 
Surface \\
Treatment
\end{tabular} & Comments & $\begin{array}{l}\text { Weight in } \\
\text { grams }\end{array}$ & $\begin{array}{l}\text { Length in } \\
\mathrm{mm}\end{array}$ & $\begin{array}{c}\text { Width in } \\
\mathrm{mm}\end{array}$ & $\begin{array}{c}\text { Thickness in } \\
\mathrm{mm}\end{array}$ \\
\hline 53.1 & 101 & 3 & & 7 & & $70-80$ & & 76 & 50 & 1 & & Prehistoric & Silicified Wood & Unknown & Debitage & Chip & Decorticated & $\begin{array}{l}\text { Thermally } \\
\text { Altered }\end{array}$ & na & na & na & na & na \\
\hline 53.10 & 101 & 3 & & 7 & & \begin{tabular}{ll|}
$70-80$ \\
\end{tabular} & & 76 & 50 & 1 & & Prehistoric & Silicified Wood & Unknown & Debitage & \begin{tabular}{|l|} 
Secondary \\
Flake
\end{tabular} & Medial Fragment & na & na & na & na & na & na \\
\hline 53.11 & 101 & 3 & & 7 & & $70-80$ & & 76 & 50 & 1 & & Prehistoric & Silicified Wood & Unknown & Debitage & $\begin{array}{l}\text { Secondary } \\
\text { Flake }\end{array}$ & Medial Fragment & na & na & na & na & na & na \\
\hline 53.12 & 101 & 3 & & 7 & & 70-80 & & 76 & 50 & 1 & & Prehistoric & Silicified Wood & Unknown & Debitage & \begin{tabular}{|l} 
Secondary \\
Flake
\end{tabular} & Distal Fragment & $\begin{array}{l}\text { Thermally } \\
\text { Altered }\end{array}$ & na & na & na & na & na \\
\hline 53.13 & 101 & 3 & & 7 & & $70-80$ & & 76 & 50 & 1 & & Prehistoric & Silicified Wood & Unknown & Debitage & Tertiary Flake & Medial Fragment & na & na & na & na & na & na \\
\hline 53.14 & 101 & 3 & & 7 & & $70-80$ & & 76 & 50 & 1 & & Prehistoric & Metaquartzite & Unknown & Debitage & \begin{tabular}{|l|} 
Secondary \\
Flake
\end{tabular} & Proximal Fragment & $\begin{array}{l}\text { Thermally } \\
\text { Altered }\end{array}$ & na & na & na & na & na \\
\hline 53.15 & 101 & 3 & & 7 & & $70-80$ & & 76 & 50 & 1 & & Prehistoric & Silicified Wood & Unknown & Debitage & Tertiary Flake & Proximal Fragment & \begin{tabular}{|l} 
Thermally \\
Altered
\end{tabular} & na & na & na & na & na \\
\hline 53.2 & 101 & 3 & & 7 & & \begin{tabular}{ll|}
$70-80$ \\
\end{tabular} & & 76 & 50 & 1 & & Prehistoric & Chert & Unknown & Debitage & $\begin{array}{l}\text { Secondary } \\
\text { Flake }\end{array}$ & Proximal Fragment & na & na & na & na & na & na \\
\hline 53.3 & 101 & 3 & & 7 & & $70-80$ & & 76 & 50 & 1 & & Prehistoric & Metaquartzite & Unknown & Debitage & Chip & Decorticated & $\begin{array}{l}\text { Thermally } \\
\text { Altered }\end{array}$ & na & na & na & na & na \\
\hline $\begin{array}{ll}53.4 \\
\end{array}$ & 101 & 3 & & 7 & & $70-80$ & & 76 & 50 & 1 & & Prehistoric & Metaquartzite & Unknown & Debitage & \begin{tabular}{|l|} 
Secondary \\
Flake
\end{tabular} & Medial Fragment & $\begin{array}{l}\text { Thermally } \\
\text { Altered }\end{array}$ & na & na & na & na & na \\
\hline 53.5 & 101 & 3 & & 7 & & 70-80 & & 76 & 50 & 2 & & Prehistoric & Metaquartzite & Unknown & Debitage & $\begin{array}{l}\text { Secondary } \\
\text { Flake }\end{array}$ & Distal Fragment & \begin{tabular}{|l} 
Thermally \\
Altered
\end{tabular} & na & na & na & na & na \\
\hline 53.6 & 101 & 3 & & 7 & & \begin{tabular}{ll|}
$70-80$ & \\
\end{tabular} & & 76 & 50 & 1 & & Prehistoric & Orthoquartzite & Unknown & Debitage & Tertiary Flake & Proximal Fragment & na & na & na & na & na & na \\
\hline 53.7 & 101 & 3 & & 7 & & \begin{tabular}{ll|}
$70-80$ \\
\end{tabular} & & 76 & 50 & 1 & & Prehistoric & Metaquartzite & Unknown & Debitage & Tertiary Flake & Medial Fragment & na & na & na & na & na & na \\
\hline $\begin{array}{ll}53.8 \\
\end{array}$ & 101 & 3 & & 7 & & \begin{tabular}{ll|}
$70-80$ \\
\end{tabular} & & 76 & 50 & 2 & & Prehistoric & Metaquartzite & Unknown & Debitage & Tertiary Flake & Distal Fragment & $\begin{array}{l}\text { Thermally } \\
\text { Altered }\end{array}$ & na & na & na & na & na \\
\hline 53.9 & 101 & 3 & & 7 & & 70-80 & & 76 & 50 & 1 & & Prehistoric & Orthoquartzite & Unknown & Debitage & Tertiary Flake & Distal Fragment & na & na & na & na & na & na \\
\hline 55 & 50 & 4 & & 1 & & $12-30$ & & 75 & 49 & 1 & & Prehistoric & Silicified Wood & Unknown & Debitage & \begin{tabular}{|l}
$\begin{array}{l}\text { Secondary } \\
\text { Flake }\end{array}$ \\
Fecolate \\
Flake \\
\end{tabular} & Proximal Fragment & $\begin{array}{l}\text { Thermally } \\
\text { Altered }\end{array}$ & na & na & na & na & na \\
\hline 56.1 & 52 & 4 & & 2 & & $20-30$ & & 75 & 49 & 1 & & Prehistoric & Silicified Wood & Unknown & Debitage & $\begin{array}{l}\text { Secondary } \\
\text { Flake }\end{array}$ & Proximal Fragment & $\begin{array}{l}\text { Thermally } \\
\text { Altered }\end{array}$ & na & na & na & na & na \\
\hline 56.2 & 52 & 4 & & 2 & & $20-30$ & & 75 & 49 & 1 & & Prehistoric & Silicified Wood & Unknown & Debitage & Tertiary Flake & Proximal Fragment & $\begin{array}{l}\text { Thermally } \\
\text { Altered }\end{array}$ & na & na & na & na & na \\
\hline 56.3 & 52 & 4 & & 2 & & 20-30 & & 75 & 49 & 1 & & Prehistoric & Silicified Wood & Unknown & Ground stone & & & na & & 0.42 & & & na \\
\hline 57.10 & 54 & 4 & & 3 & & $30-40$ & & 75 & 49 & 1 & & Prehistoric & Silicified Wood & Unknown & \begin{tabular}{|l} 
Debitage \\
\end{tabular} & \begin{tabular}{|l|} 
Secondary \\
Flake
\end{tabular} & Complete & na & na & na & na & na & na \\
\hline \begin{tabular}{ll|}
57.1 \\
\end{tabular} & 54 & 4 & & 3 & & $30-40$ & & 75 & 49 & 1 & & Prehistoric & Chert & Unknown & Debitage & Tertiary Flake & Proximal Fragment & na & na & na & na & na & na \\
\hline 57.11 & 54 & 4 & & 3 & & $30-40$ & & 75 & 49 & 1 & & Prehistoric & Silicified Wood & Unknown & Debitage & $\begin{array}{l}\text { Secondary } \\
\text { Flake }\end{array}$ & Distal Fragment & na & na & na & na & na & na \\
\hline 57.12 & 54 & 4 & & 3 & & $30-40$ & & 75 & 49 & 2 & & Prehistoric & Silicified Wood & Unknown & Debitage & $\begin{array}{l}\text { Secondary } \\
\text { Flake }\end{array}$ & Distal Fragment & na & na & na & na & na & na \\
\hline 57.13 & 54 & 4 & & 3 & & $30-40$ & & 75 & 49 & 2 & & Prehistoric & Silicified Wood & Unknown & Debitage & Tertiary Flake & Distal Fragment & na & na & na & na & na & na \\
\hline \begin{tabular}{|l|}
57.14 \\
\end{tabular} & 54 & 4 & & 3 & & $30-40$ & & 75 & 49 & 1 & & Prehistoric & Hematitic Sandstone & Unknown & Debitage & Tertiary Flake & Medial Fragment & $\begin{array}{l}\text { Thermally } \\
\text { Altered }\end{array}$ & na & na & na & na & na \\
\hline 57.15 & 54 & 4 & & 3 & & $30-40$ & & 75 & 49 & 1 & & Prehistoric & Chert & Unknown & Debitage & Tertiary Flake & Proximal Fragment & $\begin{array}{l}\text { Thermally } \\
\text { Altered }\end{array}$ & na & na & na & na & na \\
\hline 57.16 & 54 & 4 & & 3 & & 30-40 & & 75 & 49 & 2 & & Prehistoric & Metaquartzite & Unknown & Debitage & Tertiary Flake & Proximal Fragment & $\begin{array}{l}\text { Thermally } \\
\text { Altered }\end{array}$ & na & na & na & na & na \\
\hline
\end{tabular}




\begin{tabular}{|c|c|c|c|c|c|c|c|c|c|c|c|c|c|c|c|c|c|c|c|c|c|c|c|}
\hline L Lt No. & FS No. & $\begin{array}{l}\text { Unit } \\
\text { No. }\end{array}$ & \begin{tabular}{|l|} 
ST \\
No. \\
\end{tabular} & Level & $\begin{array}{l}\text { Depth } \\
\text { (cmbs) }\end{array}$ & $\begin{array}{l}\text { Depth } \\
\text { (cmbd) }\end{array}$ & Provience & Northing & Easting & $\begin{array}{c}\text { No. of } \\
\text { Specimens }\end{array}$ & $\begin{array}{l}\text { Time } \\
\text { Period }\end{array}$ & Era/Phase & Artifact Material & Use Context & $\begin{array}{c}\text { Artifact } \\
\text { Description }\end{array}$ & $\begin{array}{l}\text { Artifact Sub- } \\
\text { description }\end{array}$ & $\begin{array}{c}\text { Artifact } \\
\text { Form/Condition }\end{array}$ & \begin{tabular}{|c|} 
Surface \\
Treatment
\end{tabular} & Comments & $\begin{array}{c}\text { Weight in } \\
\text { grams }\end{array}$ & $\begin{array}{l}\text { Length in } \\
\mathrm{mm}\end{array}$ & $\begin{array}{c}\text { Width in } \\
\mathrm{mm}\end{array}$ & $\begin{array}{c}\text { Thickness in } \\
\mathrm{mm}\end{array}$ \\
\hline 57.17 & 54 & 4 & & 3 & & $30-40$ & & 75 & 49 & 2 & & Prehistoric & Orthoquartzite & Unknown & Debitage & \begin{tabular}{|l} 
secondary \\
Flake
\end{tabular} & Medial Fragment & $\begin{array}{l}\text { Thermally } \\
\text { Altered }\end{array}$ & na & na & na & na & na \\
\hline \begin{tabular}{ll|}
57.18 \\
\end{tabular} & 54 & 4 & & 3 & & $30-40$ & & 75 & 49 & 1 & & Prehistoric & Silicified Wood & Unknown & Debitage & Tertiary Flake & Medial Fragment & na & na & na & na & na & na \\
\hline 57.2 & 54 & 4 & & 3 & & $30-40$ & & 75 & 49 & 1 & & Prehistoric & Chert & Unknown & \begin{tabular}{|l} 
Debitage \\
\end{tabular} & \begin{tabular}{|l|} 
Tertiary Flake \\
\end{tabular} & Medial Fragment & na & na & na & na & na & na \\
\hline 57.3 & 54 & 4 & & 3 & & $30-40$ & & 75 & 49 & 1 & & Prehistoric & Silicified Wood & Unknown & \begin{tabular}{|l} 
Debitage \\
\end{tabular} & \begin{tabular}{|l|} 
Tertiary Flake \\
\end{tabular} & Proximal Fragment & na & na & na & na & na & na \\
\hline \begin{tabular}{ll|}
57.4 \\
\end{tabular} & 54 & 4 & & 3 & & $30-40$ & & 75 & 49 & 1 & & Prehistoric & Metaquartzite & Unknown & Debitage & $\begin{array}{l}\begin{array}{l}\text { Secondary } \\
\text { Flake }\end{array} \\
\end{array}$ & Proximal Fragment & $\begin{array}{l}\text { Thermally } \\
\text { Altered }\end{array}$ & na & na & na & na & na \\
\hline 57.5 & 54 & 4 & & 3 & & $30-40$ & & 75 & 49 & 1 & & Prehistoric & Metaquartzite & Unknown & Debitage & $\begin{array}{l}\begin{array}{l}\text { Secondary } \\
\text { Flake }\end{array} \\
\end{array}$ & Medial Fragment & $\begin{array}{l}\text { Thermally } \\
\text { Altered }\end{array}$ & na & na & na & na & na \\
\hline 57.6 & 54 & 4 & & 3 & & $30-40$ & & 75 & 49 & 3 & & Prehistoric & Metaquartzite & Unknown & Debitage & \begin{tabular}{|l} 
Secondary \\
Flake
\end{tabular} & Distal Fragment & \begin{tabular}{|l|} 
Thermally \\
Altered
\end{tabular} & na & na & na & na & na \\
\hline 57.7 & 54 & 4 & & 3 & & $30-40$ & & 75 & 49 & 1 & & Prehistoric & Metaquartzite & Unknown & Debitage & Tertiary Flake & Medial Fragment & \begin{tabular}{|l|} 
Thermally \\
Altered
\end{tabular} & na & na & na & na & na \\
\hline \begin{tabular}{|l|l|}
57.8 \\
\end{tabular} & 54 & 4 & & 3 & & $30-40$ & & 75 & 49 & 2 & & Prehistoric & Metaquartzite & Unknown & Debitage & Tertiary Flake & Distal Fragment & \begin{tabular}{|l|}
$\begin{array}{l}\text { Thermally } \\
\text { Altered }\end{array}$ \\
\end{tabular} & na & na & na & na & na \\
\hline \begin{tabular}{ll|}
57.9 \\
\end{tabular} & 54 & 4 & & 3 & & $30-40$ & & 75 & 49 & 1 & & Prehistoric & Orthoquartzite & Unknown & Debitage & $\begin{array}{l}\begin{array}{l}\text { Secondary } \\
\text { Flake }\end{array} \\
\end{array}$ & Medial Fragment & na & na & na & na & na & na \\
\hline 58.1 & 58 & 4 & & 4 & & $40-50$ & & 75 & 49 & 6 & & Prehistoric & Metaquartzite & Unknown & Debitage & $\begin{array}{l}\text { Secondary } \\
\text { Flake }\end{array}$ & Medial Fragment & \begin{tabular}{|l} 
Thermally \\
Altered
\end{tabular} & na & na & na & na & na \\
\hline 58.10 & 59 & 4 & & 4 & & $40-50$ & & 75 & 49 & 1 & & Prehistoric & Metaquartzite & Unknown & Debitage & Tertiary Flake & Proximal Fragment & \begin{tabular}{|l|} 
Thermally \\
Altered
\end{tabular} & na & na & na & na & na \\
\hline 58.2 & 58 & 4 & & 4 & & $40-50$ & & 75 & 49 & 1 & & Prehistoric & Metaquartzite & Unknown & Debitage & $\begin{array}{l}\text { Secondary } \\
\text { Flake }\end{array}$ & Distal Fragment & \begin{tabular}{|l|}
$\begin{array}{l}\text { Thermally } \\
\text { Altered }\end{array}$ \\
\end{tabular} & na & na & na & na & na \\
\hline \begin{tabular}{|c|}
58.3 \\
\end{tabular} & 58 & 4 & & 4 & & $40-50$ & & 75 & 49 & 1 & & Prehistoric & Metaquartzite & Unknown & Debitage & Tertiary Flake & Medial Fragment & \begin{tabular}{|l|}
$\begin{array}{l}\text { Thermally } \\
\text { Altered }\end{array}$ \\
\end{tabular} & na & na & na & na & na \\
\hline 58.4 & 58 & 4 & & 4 & & $40-50$ & & 75 & 49 & 1 & & Prehistoric & Metaquartzite & Unknown & Debitage & Tertiary Flake & Distal Fragment & $\begin{array}{l}\text { Thermally } \\
\text { Altered }\end{array}$ & na & na & na & na & na \\
\hline 58.5 & 58 & 4 & & 4 & & $40-50$ & & 75 & 49 & 1 & & Prehistoric & Silicified Wood & Unknown & Debitage & $\begin{array}{l}\text { Secondary } \\
\text { Flake }\end{array}$ & Proximal Fragment & na & na & na & na & na & na \\
\hline \begin{tabular}{|c|}
58.6 \\
\end{tabular} & 58 & 4 & & 4 & & $40-50$ & & 75 & 49 & 1 & & Prehistoric & Silicified Wood & Unknown & Debitage & $\begin{array}{l}\text { Secondary } \\
\text { Flake }\end{array}$ & Complete & na & na & na & na & na & na \\
\hline 58.7 & 58 & 4 & & 4 & & $40-50$ & & 75 & 49 & 1 & & Prehistoric & Silicified Wood & Unknown & Debitage & Tertiary Flake & Complete & na & na & na & na & na & na \\
\hline \begin{tabular}{|c|}
58.8 \\
\end{tabular} & 58 & 4 & & 4 & & $40-50$ & & 75 & 49 & 1 & & Prehistoric & Hematitic Sandstone & Unknown & Debitage & \begin{tabular}{|l|} 
Tertiary Flake \\
\end{tabular} & Medial Fragment & \begin{tabular}{|l|} 
Thermally \\
Altered
\end{tabular} & na & na & na & na & na \\
\hline \begin{tabular}{|c|}
59.1 \\
\end{tabular} & 61 & 4 & & 5 & & 50-60 & & 75 & 49 & 1 & & Prehistoric & Chert & Unknown & Debitage & $\begin{array}{l}\text { Secondary } \\
\text { Flake }\end{array}$ & Distal Fragment & na & na & na & na & na & na \\
\hline 59.10 & 61 & 4 & & 5 & & $50-60$ & & 75 & 49 & 1 & & Prehistoric & Silicified Wood & Unknown & Debitage & Tertiary Flake & Medial Fragment & na & na & na & na & na & na \\
\hline \begin{tabular}{ll|}
59.11 \\
\end{tabular} & 61 & 4 & & 5 & & 50-60 & & 75 & 49 & 1 & & Prehistoric & Orthoquartzite & Unknown & Debitage & $\begin{array}{l}\text { Secondary } \\
\text { Flake }\end{array}$ & Distal Fragment & \begin{tabular}{|l} 
Thermally \\
Altered
\end{tabular} & na & na & na & na & na \\
\hline 59.12 & 61 & 4 & & 5 & & 50-60 & & 75 & 49 & 1 & & Prehistoric & Silicified Wood & Unknown & Debitage & Tertiary Flake & Proximal Fragment & $\begin{array}{l}\text { Thermally } \\
\text { Altered }\end{array}$ & na & na & na & na & na \\
\hline \begin{tabular}{|l|}
59.13 \\
\end{tabular} & 61 & 4 & & 5 & & $50-60$ & & 75 & 49 & 1 & & Prehistoric & Silicified Wood & Unknown & Debitage & $\begin{array}{l}\text { Secondary } \\
\text { Flake }\end{array}$ & Proximal Fragment & \begin{tabular}{|l|} 
Thermally \\
Altered
\end{tabular} & na & na & na & na & na \\
\hline 59.2 & 61 & 4 & & 5 & & 50-60 & & 75 & 49 & 2 & & Prehistoric & Metaquartzite & Unknown & Debitage & $\begin{array}{l}\text { Secondary } \\
\text { Flake }\end{array}$ & Proximal Fragment & \begin{tabular}{|l|}
$\begin{array}{l}\text { Thermally } \\
\text { Altered }\end{array}$ \\
\end{tabular} & na & na & na & na & na \\
\hline 59.3 & 61 & 4 & & 5 & & 50-60 & & 75 & 49 & 2 & & Prehistoric & Metaquartzite & Unknown & Debitage & $\begin{array}{l}\text { Secondary } \\
\text { Flake }\end{array}$ & Medial Fragment & $\begin{array}{l}\text { Thermally } \\
\text { Altered }\end{array}$ & na & na & na & na & na \\
\hline 59.4 & 61 & 4 & & 5 & & $50-60$ & & 75 & 49 & 1 & & Prehistoric & Metaquartzite & Unknown & Debitage & $\begin{array}{l}\text { Secondary } \\
\text { Flake }\end{array}$ & Distal Fragment & \begin{tabular}{|l} 
Thermally \\
Altered
\end{tabular} & na & na & na & na & na \\
\hline
\end{tabular}




\begin{tabular}{|c|c|c|c|c|c|c|c|c|c|c|c|c|c|c|c|c|c|c|c|c|c|c|c|}
\hline Lot No. & FS No. & $\begin{array}{l}\text { Unit } \\
\text { No. }\end{array}$ & $\begin{array}{l}\text { ST } \\
\text { No. }\end{array}$ & | Level & $\begin{array}{l}\text { Depth } \\
\text { (cmbs) }\end{array}$ & $\begin{array}{l}\text { Depth } \\
\text { (cmbd) }\end{array}$ & Provience & Northing & Easting & $\begin{array}{c}\text { No. of } \\
\text { Specimens }\end{array}$ & $\begin{array}{c}\text { Time } \\
\text { Period }\end{array}$ & Era/ Phase & Artifact Material & Use Context & $\begin{array}{c}\text { Artifact } \\
\text { Description }\end{array}$ & $\begin{array}{c}\text { Artifact Sub- } \\
\text { description }\end{array}$ & $\begin{array}{c}\text { Artifact } \\
\text { Form/Condition }\end{array}$ & \begin{tabular}{|c} 
Surface \\
Treatment
\end{tabular} & Comments & $\begin{array}{c}\text { Weight in } \\
\text { grams }\end{array}$ & $\begin{array}{l}\text { Length in } \\
\mathrm{mm}\end{array}$ & $\begin{array}{l}\text { Width in } \\
\mathrm{mm}\end{array}$ & \begin{tabular}{|c|} 
Thickness in \\
$\mathrm{mm}$
\end{tabular} \\
\hline 59.5 & 61 & 4 & & 5 & & 50-60 & & 75 & 49 & 3 & & Prehistoric & Metaquartzite & Unknown & Debitage & Tertiary Flake & Medial Fragment & \begin{tabular}{|l} 
Thermally \\
Altered
\end{tabular} & na & na & na & na & na \\
\hline 59.6 & 61 & 4 & & 5 & & $50-60$ & & 75 & 49 & 1 & & Prehistoric & Silicified Wood & Unknown & Debitage & $\begin{array}{l}\text { Secondary } \\
\text { Flake } \\
\end{array}$ & Medial Fragment & $\begin{array}{l}\text { Thermally } \\
\text { Altered }\end{array}$ & na & na & na & na & na \\
\hline 59.7 & 61 & 4 & & 5 & & $50-60$ & & 75 & 49 & 1 & & Prehistoric & Silicified Wood & Unknown & \begin{tabular}{|l} 
Debitage \\
\end{tabular} & $\begin{array}{l}\text { Secondary } \\
\text { Flake } \\
\end{array}$ & Medial Fragment & na & na & na & na & na & na \\
\hline 59.8 & 61 & 4 & & 5 & & $50-60$ & & 75 & 49 & 1 & & Prehistoric & Silicified Wood & |Unknown & Debitage & \begin{tabular}{|l|} 
Secondary \\
Flake
\end{tabular} & Distal Fragment & \begin{tabular}{|l} 
Thermally \\
Altered
\end{tabular} & na & na & na & na & na \\
\hline 59.9 & 61 & 4 & & 5 & & 50-60 & & 75 & 49 & 1 & & Prehistoric & Silicified Wood & Unknown & Debitage & $\begin{array}{l}\text { Secondary } \\
\text { Flake }\end{array}$ & Distal Fragment & na & na & na & na & na & na \\
\hline 60.1 & 66 & 4 & & 6 & & 60-70 & & 75 & 49 & 1 & & Prehistoric & Chert & Unknown & Dart Point & Untyped & Distal Fragment & $\begin{array}{l}\text { Thermally } \\
\text { Altered }\end{array}$ & $\begin{array}{l}\text { Reworked, basal edge missing, } \\
\text { indistinct squared shoulders, } \\
\text { slightly recurved lateral edges, } \\
\text { medial ridge on both faces, well } \\
\text { thinned across entirety of } \\
\text { specimen, utilization as perforator } \\
\text { on distal tip, poor material, many } \\
\text { inclusions, very thick proximal- } \\
\text { medial section }\end{array}$ & 2.13 & 25.39 & 17.01 & 7.05 \\
\hline 60.10 & 67 & 4 & & 6 & & $\begin{array}{ll}60-70 \\
\end{array}$ & & 75 & 49 & 2 & & Prehistoric & Silicified Wood & Unknown & Debitage & Tertiary Flake & Proximal Fragment & na & na & na & na & na & na \\
\hline 60.11 & 67 & 4 & & 6 & & $\begin{array}{ll}60-70 \\
\end{array}$ & & 75 & 49 & 1 & & Prehistoric & \begin{tabular}{|l|} 
Orthoquartzite \\
\end{tabular} & Unknown & Debitage & \begin{tabular}{|l|}
$\begin{array}{l}\text { Secondary } \\
\text { Flake }\end{array}$ \\
\end{tabular} & Proximal Fragment & $\begin{array}{l}\text { Thermally } \\
\text { Altered }\end{array}$ & na & na & na & na & na \\
\hline 60.2 & 67 & 4 & & 6 & & $\begin{array}{ll}60-70 \\
\end{array}$ & & 75 & 49 & 1 & & Prehistoric & Chert & Unknown & Debitage & $\begin{array}{l}\text { Secondary } \\
\text { Flake }\end{array}$ & Proximal Fragment & na & na & na & na & na & na \\
\hline 60.3 & 67 & 4 & & 6 & & 60-70 & & 75 & 49 & 1 & & Prehistoric & Metaquartzite & Unknown & Debitage & \begin{tabular}{|l|} 
Secondary \\
Flake
\end{tabular} & Distal Fragment & $\begin{array}{l}\text { Thermally } \\
\text { Altered }\end{array}$ & na & na & na & na & na \\
\hline 60.4 & 67 & 4 & & 6 & & 60-70 & & 75 & 49 & 3 & & Prehistoric & Metaquartzite & Unknown & Debitage & Tertiary Flake & Proximal Fragment & $\begin{array}{l}\text { Thermally } \\
\text { Altered }\end{array}$ & na & na & na & na & na \\
\hline 60.5 & 67 & 4 & & 6 & & 60-70 & & 75 & 49 & 1 & & Prehistoric & Metaquartzite & Unknown & Debitage & Tertiary Flake & Distal Fragment & $\begin{array}{l}\text { Thermally } \\
\text { Altered }\end{array}$ & na & na & na & na & na \\
\hline 60.6 & 67 & 4 & & 6 & & $\begin{array}{ll}60-70 \\
\end{array}$ & & 75 & 49 & 1 & & Prehistoric & Silicified Wood & Unknown & Debitage & \begin{tabular}{|l|}
$\begin{array}{l}\text { Secondary } \\
\text { Flake }\end{array}$ \\
\end{tabular} & Medial Fragment & $\begin{array}{l}\text { Thermally } \\
\text { Altered }\end{array}$ & na & na & na & na & na \\
\hline 60.7 & 67 & 4 & & 6 & & $\begin{array}{ll}60-70 \\
\end{array}$ & & 75 & 49 & 2 & & Prehistoric & Silicified Wood & Unknown & Debitage & \begin{tabular}{|l|} 
\\
Secondary \\
Flake
\end{tabular} & Proximal Fragment & na & na & na & na & na & na \\
\hline 60.8 & 67 & 4 & & 6 & & $60-70$ & & 75 & 49 & 1 & & Prehistoric & Silicified Wood & Unknown & \begin{tabular}{|l|l|} 
Debitage \\
\end{tabular} & Tertiary Flake & Distal Fragment & na & na & na & na & na & na \\
\hline 60.9 & 67 & 4 & & 6 & & 60-70 & & 75 & 49 & 2 & & Prehistoric & Silicified Wood & Unknown & Debitage & Tertiary Flake & Medial Fragment & $\begin{array}{l}\text { Thermally } \\
\text { Altered }\end{array}$ & na & na & na & na & na \\
\hline 61.1 & 69 & 4 & & 7 & & $70-80$ & & 75 & 49 & 1 & & Prehistoric & Metaquartzite & Unknown & Biface & na & Distal Fragment & $\begin{array}{l}\text { Thermally } \\
\text { Altered }\end{array}$ & $\begin{array}{l}\text { No stage or shape given due to } \\
\text { fragentary nature, no cortex } \\
\text { remaining, straight lateral edges, } \\
\text { pointed distal tip, medial ridge on } \\
\text { both faces, well thinned across } \\
\text { entirety of specimen, slight } \\
\text { battering on both lateral-distal } \\
\text { edges, snap fracture }\end{array}$ & 0.52 & 16.07 & 8.77 & 4.65 \\
\hline 61.10 & 70 & 4 & & 7 & & $70-80$ & & 75 & 49 & 1 & & Prehistoric & Silicified Wood & Unknown & Debitage & Chip & Corticated & $\begin{array}{l}\text { Thermally } \\
\text { Altered }\end{array}$ & na & na & na & na & na \\
\hline 61.11 & 70 & 4 & & 7 & & $70-80$ & & 75 & 49 & 2 & & Prehistoric & Silicified Wood & Unknown & Debitage & Tertiary Flake & Medial Fragment & na & na & na & na & na & na \\
\hline 61.12 & 70 & 4 & & 7 & & $70-80$ & & 75 & 49 & 1 & & Prehistoric & Silicified Wood & Unknown & Debitage & Tertiary Flake & Distal Fragment & na & na & na & na & na & na \\
\hline
\end{tabular}




\begin{tabular}{|c|c|c|c|c|c|c|c|c|c|c|c|c|c|c|c|c|c|c|c|c|c|c|c|}
\hline Lot No. & FS No. & \begin{tabular}{|l} 
Unit \\
No.
\end{tabular} & \begin{tabular}{|l|} 
ST \\
No. \\
\end{tabular} & Level & \begin{tabular}{|l} 
Depth \\
(cmbs) \\
\end{tabular} & $\begin{array}{l}\text { Depth } \\
\text { (cmbd) }\end{array}$ & Provience & Northing & Easting & $\begin{array}{c}\text { No. of } \\
\text { Specimens }\end{array}$ & $\begin{array}{c}\text { Time } \\
\text { Period }\end{array}$ & Era/Phase & Artifact Material & Use Context & $\begin{array}{c}\text { Artifact } \\
\text { Description }\end{array}$ & $\begin{array}{c}\text { Artifact Sub- } \\
\text { description }\end{array}$ & $\begin{array}{c}\text { Artifact } \\
\text { Form/Condition }\end{array}$ & $\begin{array}{c}\text { Surface } \\
\text { Treatment }\end{array}$ & Comments & $\begin{array}{l}\text { Weight in } \\
\text { grams }\end{array}$ & $\begin{array}{c}\text { Length in } \\
\mathrm{mm}\end{array}$ & $\begin{array}{c}\text { Width in } \\
\mathrm{mm}\end{array}$ & $\begin{array}{c}\text { Thickness in } \\
\mathrm{mm}\end{array}$ \\
\hline 61.13 & 70 & 4 & & 7 & & $70-80$ & & 75 & 49 & 1 & & Prehistoric & Silicified Wood & \begin{tabular}{|l|l|} 
Unknown \\
\end{tabular} & \begin{tabular}{|l|} 
Debitage \\
\end{tabular} & $\begin{array}{l}\text { Tertiary Flake } \\
\end{array}$ & \begin{tabular}{|l} 
Proximal Fragment \\
\end{tabular} & na & na & na & na & na & na \\
\hline $\begin{array}{ll}61.14 \\
\end{array}$ & 70 & 4 & & 7 & & $70-80$ & & 75 & 49 & 1 & & Prehistoric & \begin{tabular}{|l} 
Metaquartzite \\
\end{tabular} & Unknown & Debitage & Chip & Decorticated & $\begin{array}{l}\text { Thermally } \\
\text { Altered }\end{array}$ & na & na & na & na & na \\
\hline 61.2 & 70 & 4 & & 7 & & $70-80$ & & 75 & 49 & 1 & & Prehistoric & Metaquartzite & Unknown & Debitage & $\begin{array}{l}\text { Secondary } \\
\text { Flake }\end{array}$ & Complete & \begin{tabular}{|l|}
$\begin{array}{l}\text { Thermally } \\
\text { Altered }\end{array}$ \\
\end{tabular} & na & na & na & na & na \\
\hline 61.3 & 70 & 4 & & 7 & & $70-80$ & & 75 & 49 & 1 & & Prehistoric & Metaquartzite & Unknown & Debitage & $\begin{array}{l}\text { Secondary } \\
\text { Flake }\end{array}$ & Medial Fragment & \begin{tabular}{|l|} 
Thermally \\
Altered
\end{tabular} & na & na & na & na & na \\
\hline 61.4 & 70 & 4 & & 7 & & $70-80$ & & 75 & 49 & 2 & & Prehistoric & Metaquartzite & Unknown & Debitage & Tertiary Flake & Proximal Fragment & \begin{tabular}{|l} 
Thermally \\
Altered
\end{tabular} & na & na & na & na & na \\
\hline 61.5 & 70 & 4 & & 7 & & $70-80$ & & 75 & 49 & 1 & & Prehistoric & Metaquartzite & Unknown & Debitage & Tertiary Flake & Medial Fragment & na & na & na & na & na & 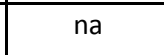 \\
\hline 61.6 & 70 & 4 & & 7 & & $70-80$ & & 75 & 49 & 2 & & Prehistoric & Metaquartzite & Unknown & Debitage & Tertiary Flake & Distal Fragment & \begin{tabular}{|l} 
Thermally \\
Altered
\end{tabular} & na & na & na & na & na \\
\hline $\begin{array}{ll}61.7 \\
\end{array}$ & 70 & 4 & & 7 & & $70-80$ & & 75 & 49 & 1 & & Prehistoric & Metaquartzite & Unknown & Debitage & Tertiary Flake & Distal Fragment & na & na & $\mathrm{na}$ & na & na & na \\
\hline 61.8 & 70 & 4 & & 7 & & $70-80$ & & 75 & 49 & 1 & & Prehistoric & Silicified Wood & Unknown & Debitage & $\begin{array}{l}\text { Secondary } \\
\text { Flake }\end{array}$ & Proximal Fragment & na & na & na & na & na & na \\
\hline 61.9 & 70 & 4 & & 7 & & $70-80$ & & 75 & 49 & 1 & & Prehistoric & Silicified Wood & Unknown & Debitage & \begin{tabular}{|l|} 
Secondary \\
Flake
\end{tabular} & Proximal Fragment & \begin{tabular}{|l} 
Thermally \\
Altered
\end{tabular} & na & na & na & na & na \\
\hline 62.10 & 94 & 5 & & 1 & & $0-30$ & & 74 & 50 & 1 & & Prehistoric & Metaquartzite & Unknown & Debitage & Chip & Corticated & \begin{tabular}{|l} 
Thermally \\
Altered
\end{tabular} & na & na & na & na & na \\
\hline 62.1 & 94 & 5 & & 1 & & $0-30$ & & 74 & 50 & 1 & & Prehistoric & Chert & Unknown & Debitage & \begin{tabular}{|l|} 
Secondary \\
Flake
\end{tabular} & Medial Fragment & na & na & na & na & na & na \\
\hline 62.11 & 94 & 5 & & 1 & & $0-30$ & & 74 & 50 & 1 & & Prehistoric & Silicified Wood & Unknown & Debitage & Tertiary Flake & 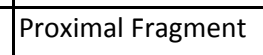 & na & na & na & na & na & na \\
\hline 62.2 & 94 & 5 & & 1 & & $0-30$ & & 74 & 50 & 1 & & Prehistoric & Chert & Unknown & Debitage & Tertiary Flake & Proximal Fragment & \begin{tabular}{|l} 
Thermally \\
Altered
\end{tabular} & na & na & na & na & na \\
\hline 62.3 & 94 & 5 & & 1 & & $0-30$ & & 74 & 50 & 1 & & Prehistoric & Chert & Unknown & Debitage & Tertiary Flake & Distal Fragment & \begin{tabular}{|l} 
Thermally \\
Altered
\end{tabular} & na & na & na & na & na \\
\hline $\begin{array}{ll}62.4 \\
\end{array}$ & 94 & 5 & & 1 & & $0-30$ & & 74 & 50 & 1 & & Prehistoric & Chert & Unknown & Debitage & Tertiary Flake & Complete & na & na & na & na & na & na \\
\hline 62.5 & 94 & 5 & & 1 & & $0-30$ & & 74 & 50 & 1 & & Prehistoric & Chert & Unknown & Debitage & \begin{tabular}{|l|} 
Secondary \\
Flake
\end{tabular} & Distal Fragment & \begin{tabular}{|l|} 
Thermally \\
Altered
\end{tabular} & na & na & na & na & na \\
\hline 62.6 & 94 & 5 & & 1 & & $0-30$ & & 74 & 50 & 1 & & Prehistoric & Silicified Wood & Unknown & Debitage & $\begin{array}{l}\text { Secondary } \\
\text { Flake }\end{array}$ & Distal Fragment & na & na & na & na & na & na \\
\hline 62.7 & 94 & 5 & & 1 & & $0-30$ & & 74 & 50 & 1 & & Prehistoric & Silicified Wood & Unknown & Debitage & $\begin{array}{l}\text { Secondary } \\
\text { Flake }\end{array}$ & Complete & na & na & na & na & na & na \\
\hline 62.8 & 94 & 5 & & 1 & & $0-30$ & & 74 & 50 & 1 & & Prehistoric & Silicified Wood & Unknown & Debitage & Tertiary Flake & Medial Fragment & na & na & na & na & na & na \\
\hline 62.9 & 94 & 5 & & 1 & & $0-30$ & & 74 & 50 & 1 & & Prehistoric & Silicified Wood & Unknown & Debitage & \begin{tabular}{|l} 
Tertiary Flake \\
\end{tabular} & Distal Fragment & na & na & na & na & na & na \\
\hline 63.1 & 95 & 5 & & 2 & & $30-40$ & & 74 & 50 & 2 & & Prehistoric & Metaquartzite & Unknown & Debitage & \begin{tabular}{|l|} 
Secondary \\
Flake
\end{tabular} & 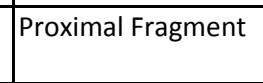 & \begin{tabular}{|l} 
Thermally \\
Altered
\end{tabular} & na & na & na & na & na \\
\hline 63.10 & 95 & 5 & & 2 & & $30-40$ & & 74 & 50 & 2 & & Prehistoric & Silicified Wood & Unknown & Debitage & Tertiary Flake & \begin{tabular}{|l|} 
Proximal Fragment \\
\end{tabular} & na & na & na & na & na & na \\
\hline 63.11 & 95 & 5 & & 2 & & $30-40$ & & 74 & 50 & 3 & & Prehistoric & Orthoquartzite & Unknown & Debitage & $\begin{array}{l}\text { Secondary } \\
\text { Flake }\end{array}$ & 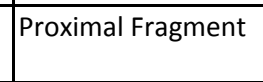 & \begin{tabular}{|l|} 
Thermally \\
Altered
\end{tabular} & na & na & na & na & na \\
\hline 63.12 & 95 & 5 & & 2 & & $30-40$ & & 74 & 50 & 1 & & Prehistoric & Orthoquartzite & Unknown & Debitage & Tertiary Flake & 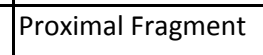 & na & na & na & na & na & na \\
\hline 63.2 & 95 & 5 & & 2 & & $30-40$ & & 74 & 50 & 3 & & Prehistoric & Metaquartzite & Unknown & Debitage & \begin{tabular}{|l|} 
Secondary \\
Flake
\end{tabular} & Medial Fragment & \begin{tabular}{|l} 
Thermally \\
Altered
\end{tabular} & na & na & na & na & na \\
\hline 63.3 & 95 & 5 & & 2 & & $30-40$ & & 74 & 50 & 1 & & Prehistoric & Metaquartzite & Unknown & Debitage & $\begin{array}{l}\text { Secondary } \\
\text { Flake }\end{array}$ & Distal Fragment & $\begin{array}{l}\text { Thermally } \\
\text { Altered }\end{array}$ & na & na & na & na & na \\
\hline
\end{tabular}




\begin{tabular}{|c|c|c|c|c|c|c|c|c|c|c|c|c|c|c|c|c|c|c|c|c|c|c|c|}
\hline Lot No. & FS No. & $\begin{array}{l}\text { Unit } \\
\text { No. }\end{array}$ & \begin{tabular}{|l|} 
ST \\
No. \\
\end{tabular} & Level & $\begin{array}{c}\text { Depth } \\
\text { (cmbs) }\end{array}$ & $\begin{array}{c}\text { Depth } \\
\text { (cmbd) }\end{array}$ & Provience & Northing & Easting & $\begin{array}{c}\text { No. of } \\
\text { Specimens }\end{array}$ & $\begin{array}{l}\text { Time } \\
\text { Period }\end{array}$ & Era/ Phase & Artifact Material & Use Context & $\begin{array}{c}\text { Artifact } \\
\text { Description }\end{array}$ & $\begin{array}{l}\text { Artifact Sub- } \\
\text { description }\end{array}$ & $\begin{array}{c}\text { Artifact } \\
\text { Form/Condition }\end{array}$ & \begin{tabular}{|c} 
Surface \\
Treatment
\end{tabular} & Comments & $\begin{array}{l}\text { Weight in } \\
\text { grams }\end{array}$ & $\begin{array}{l}\text { Length in } \\
\mathrm{mm}\end{array}$ & $\begin{array}{l}\text { Width in } \\
\mathrm{mm}\end{array}$ & $\begin{array}{c}\text { Thickness in } \\
\mathrm{mm}\end{array}$ \\
\hline 63.4 & 95 & 5 & & 2 & & $30-40$ & & 74 & 50 & 2 & & Prehistoric & Metaquartzite & Unknown & \begin{tabular}{|l|} 
Debitage \\
\end{tabular} & Tertiary Flake & Proximal Fragment & \begin{tabular}{|l} 
Thermally \\
Altered
\end{tabular} & na & na & na & na & na \\
\hline 63.5 & 95 & 5 & & 2 & & $30-40$ & & 74 & 50 & 1 & & Prehistoric & Metaquartzite & Unknown & Debitage & Tertiary Flake & Proximal Fragment & na & na & na & na & na & na \\
\hline \begin{tabular}{|l|l|}
63.6 \\
\end{tabular} & 95 & 5 & & 2 & & $30-40$ & & 74 & 50 & 1 & & Prehistoric & Silicified Wood & Unknown & Debitage & 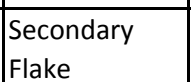 & Medial Fragment & $\begin{array}{l}\text { Thermally } \\
\text { Altered }\end{array}$ & na & na & na & na & na \\
\hline $\begin{array}{ll}63.7 \\
\end{array}$ & 95 & 5 & & 2 & & $30-40$ & & 74 & 50 & 1 & & Prehistoric & Silicified Wood & Unknown & Debitage & \begin{tabular}{|l|} 
Secondary \\
Flake
\end{tabular} & Medial Fragment & na & na & na & na & na & na \\
\hline \begin{tabular}{ll|}
63.8 \\
\end{tabular} & 95 & 5 & & 2 & & $30-40$ & & 74 & 50 & 1 & & Prehistoric & chert & Unknown & Debitage & Tertiary Flake & Proximal Fragment & na & na & na & na & na & na \\
\hline \begin{tabular}{|l|l|}
63.9 \\
\end{tabular} & 95 & 5 & & 2 & & $30-40$ & & 74 & 50 & 1 & & Prehistoric & Silicified Wood & Unknown & Debitage & Tertiary Flake & Complete & $\begin{array}{l}\text { Thermally } \\
\text { Altered }\end{array}$ & na & na & na & na & na \\
\hline 64.1 & 96 & 5 & & 3 & & $40-50$ & & 74 & 50 & 1 & & Prehistoric & Chert & Unknown & Debitage & \begin{tabular}{|l} 
Secondary \\
Flake
\end{tabular} & Complete & na & na & na & na & na & na \\
\hline \begin{tabular}{ll|}
64.10 \\
\end{tabular} & 96 & 5 & & 3 & & $40-50$ & & 74 & 50 & 1 & & Prehistoric & Chert & Unknown & Debitage & $\begin{array}{l}\text { Secondary } \\
\text { Flake }\end{array}$ & Distal Fragment & na & na & na & na & na & na \\
\hline \begin{tabular}{|l|l|}
64.11 \\
\end{tabular} & 96 & 5 & & 3 & & $40-50$ & & 74 & 50 & 1 & & Prehistoric & Metaquartzite & Unknown & Debitage & $\begin{array}{l}\text { Secondary } \\
\text { Flake } \\
\end{array}$ & \begin{tabular}{|l|} 
Distal Fragment \\
\end{tabular} & na & na & na & na & na & na \\
\hline 64.12 & 96 & 5 & & 3 & & $40-50$ & & 74 & 50 & 2 & & Prehistoric & Metaquartzite & Unknown & Debitage & Tertiary Flake & Medial Fragment & $\begin{array}{l}\text { Thermally } \\
\text { Altered }\end{array}$ & na & na & na & $\overline{\text { na }}$ & na \\
\hline \begin{tabular}{|l|}
64.13 \\
\end{tabular} & 96 & 5 & & 3 & & $40-50$ & & 74 & 50 & 1 & & Prehistoric & Metaquartzite & Unknown & Debitage & Tertiary Flake & Distal Fragment & $\begin{array}{l}\text { Thermally } \\
\text { Altered }\end{array}$ & na & na & na & na & na \\
\hline \begin{tabular}{ll|}
64.14 \\
\end{tabular} & 96 & 5 & & 3 & & $40-50$ & & 74 & 50 & 1 & & Prehistoric & Metaquartzite & Unknown & Debitage & Tertiary Flake & Distal Fragment & na & na & na & na & na & na \\
\hline 64.15 & 96 & 5 & & 3 & & $40-50$ & & 74 & 50 & 1 & & Prehistoric & Orthoquartzite & Unknown & Debitage & Tertiary Flake & Medial Fragment & na & na & na & na & na & na \\
\hline \begin{tabular}{ll|}
64.16 \\
\end{tabular} & 96 & 5 & & 3 & & $40-50$ & & 74 & 50 & 2 & & Prehistoric & Silicified Wood & Unknown & Debitage & \begin{tabular}{|l|}
$\begin{array}{l}\text { Secondary } \\
\text { Flake }\end{array}$ \\
\end{tabular} & Proximal Fragment & $\begin{array}{l}\text { Thermally } \\
\text { Altered }\end{array}$ & na & na & na & na & na \\
\hline \begin{tabular}{|c|}
64.17 \\
\end{tabular} & 96 & 5 & & 3 & & $40-50$ & & 74 & 50 & 2 & & Prehistoric & Silicified Wood & Unknown & Debitage & \begin{tabular}{|l|}
$\begin{array}{l}\text { Secondary } \\
\text { Flake }\end{array}$ \\
\end{tabular} & Medial Fragment & na & na & na & na & na & na \\
\hline \begin{tabular}{ll|}
64.18 \\
\end{tabular} & 96 & 5 & & 3 & & $40-50$ & & 74 & 50 & 1 & & Prehistoric & Silicified Wood & Unknown & Debitage & \begin{tabular}{|l|} 
Secondary \\
Flake
\end{tabular} & Distal Fragment & \begin{tabular}{|l|} 
Thermally \\
Altered
\end{tabular} & na & na & na & na & na \\
\hline \begin{tabular}{ll|}
64.19 \\
\end{tabular} & 96 & 5 & & 3 & & $40-50$ & & 74 & 50 & 1 & & Prehistoric & Silicified Wood & Unknown & Debitage & \begin{tabular}{l|} 
Secondary \\
Flake
\end{tabular} & Distal Fragment & na & na & na & na & na & na \\
\hline $\begin{array}{ll}64.2 \\
\end{array}$ & 96 & 5 & & 3 & & $40-50$ & & 74 & 50 & 1 & & Prehistoric & Chert & Unknown & Debitage & Tertiary Flake & Medial Fragment & $\begin{array}{l}\text { Thermally } \\
\text { Altered }\end{array}$ & na & na & na & na & na \\
\hline \begin{tabular}{ll|}
64.20 \\
\end{tabular} & 96 & 5 & & 3 & & $40-50$ & & 74 & 50 & 2 & & \begin{tabular}{|l|} 
Prehistoric \\
\end{tabular} & Silicified Wood & Unknown & Debitage & Tertiary Flake & Proximal Fragment & na & na & $\begin{array}{l}\mathrm{na} \\
\text { na }\end{array}$ & na & na & na \\
\hline \begin{tabular}{ll|}
64.21 \\
\end{tabular} & 96 & 5 & & 3 & & $40-50$ & & 74 & 50 & 1 & & Prehistoric & Silicified Wood & Unknown & Debitage & Tertiary Flake & Medial Fragment & $\begin{array}{l}\text { Thermally } \\
\text { Altered }\end{array}$ & na & na & na & na & na \\
\hline \begin{tabular}{ll|}
64.22 \\
\end{tabular} & 96 & 5 & & 3 & & $40-50$ & & 74 & 50 & 2 & & Prehistoric & Silicified Wood & Unknown & Debitage & Tertiary Flake & Medial Fragment & na & na & na & na & na & na \\
\hline 64.23 & 96 & 5 & & 3 & & $40-50$ & & 74 & 50 & 3 & & Prehistoric & Silicified Wood & Unknown & Debitage & Tertiary Flake & Distal Fragment & $\begin{array}{l}\text { Thermally } \\
\text { Altered }\end{array}$ & na & na & na & na & na \\
\hline \begin{tabular}{ll|}
64.24 & \\
\end{tabular} & 96 & 5 & & 3 & & $40-50$ & & 74 & 50 & 1 & & Prehistoric & Silicified Wood & Unknown & Debitage & Tertiary Flake & Proximal Fragment & $\begin{array}{l}\text { Thermally } \\
\text { Altered }\end{array}$ & na & na & na & na & na \\
\hline 64.25 & 96 & 5 & & 3 & & $40-50$ & & 74 & 50 & 2 & & \begin{tabular}{|l|} 
Prehistoric \\
\end{tabular} & Silicified Wood & Unknown & Debitage & Tertiary Flake & Distal Fragment & na & na & na & na & na & na \\
\hline \begin{tabular}{ll|}
64.26 \\
\end{tabular} & 97 & 5 & & 3 & & $40-50$ & & 74 & 50 & 1 & & Prehistoric & Silicified Wood & Unknown & Ground stone & & & $\begin{array}{l}\text { Thermally } \\
\text { Altered }\end{array}$ & & 60.60 & & & na \\
\hline \begin{tabular}{|l|l|}
64.27 & \\
\end{tabular} & 97 & 5 & & 3 & & $40-50$ & & 74 & 50 & 1 & & Prehistoric & Chert & Unknown & Debitage & Tertiary Flake & \begin{tabular}{|l|l|} 
Complete \\
\end{tabular} & na & na & na & na & na & na \\
\hline \begin{tabular}{|l|l|}
64.28 & \\
\end{tabular} & 97 & 5 & & 3 & & 40-50 & & 74 & 50 & 1 & & Prehistoric & Chert & Unknown & Debitage & \begin{tabular}{|l|} 
Secondary \\
Flake
\end{tabular} & Proximal Fragment & $\begin{array}{l}\text { Thermally } \\
\text { Altered }\end{array}$ & na & na & na & na & na \\
\hline
\end{tabular}




\begin{tabular}{|c|c|c|c|c|c|c|c|c|c|c|c|c|c|c|c|c|c|c|c|c|c|c|c|}
\hline Lot No. & FS No. & $\begin{array}{l}\text { Unit } \\
\text { No. }\end{array}$ & $\begin{array}{l}\text { ST } \\
\text { No. }\end{array}$ & \begin{tabular}{|l} 
Level \\
\end{tabular} & $\begin{array}{l}\text { Depth } \\
\text { (cmbs) }\end{array}$ & $\begin{array}{l}\text { Depth } \\
\text { (cmbd) }\end{array}$ & Provience & Northing & Easting & \begin{tabular}{|c|}
$\begin{array}{c}\text { No. of } \\
\text { Specimens }\end{array}$ \\
\end{tabular} & $\begin{array}{l}\text { Time } \\
\text { Period }\end{array}$ & Era/ Phase & Artifact Material & Use Context & $\begin{array}{c}\text { Artifact } \\
\text { Description }\end{array}$ & \begin{tabular}{|c|} 
Artifact Sub- \\
description \\
\end{tabular} & $\begin{array}{c}\text { Artifact } \\
\text { Form/Condition }\end{array}$ & $\begin{array}{c}\text { Surface } \\
\text { Treatment }\end{array}$ & Comments & $\begin{array}{l}\text { Weight in } \\
\text { grams }\end{array}$ & $\begin{array}{c}\text { Length in } \\
\mathrm{mm}\end{array}$ & $\begin{array}{c}\text { Width in } \\
\mathrm{mm}\end{array}$ & \begin{tabular}{|c|} 
Thickness in \\
$\mathrm{mm}$
\end{tabular} \\
\hline 64.29 & 97 & 5 & & 3 & & $\begin{array}{ll}40-50 \\
\end{array}$ & & 74 & 50 & 1 & & Prehistoric & Orthoquartzite & Unknown & Debitage & Tertiary Flake & Medial Fragment & $\begin{array}{l}\text { Thermally } \\
\text { Altered }\end{array}$ & na & na & na & 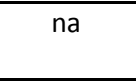 & na \\
\hline $\begin{array}{l}64.3 \\
\end{array}$ & 96 & 5 & & 3 & & $\begin{array}{ll}40-50 \\
\end{array}$ & & 74 & 50 & 1 & & \begin{tabular}{|l|} 
Prehistoric \\
\end{tabular} & Chert & Unknown & Debitage & Tertiary Flake & Medial Fragment & na & na & na & na & na & na \\
\hline 64.30 & 97 & 5 & & 3 & & $40-50$ & & 74 & 50 & 1 & & Prehistoric & Chert & Unknown & Debitage & $\begin{array}{l}\text { Secondary } \\
\text { Flake }\end{array}$ & Proximal Fragment & na & na & na & na & na & na \\
\hline 64.4 & 96 & 5 & & 3 & & $40-50$ & & 74 & 50 & 1 & & Prehistoric & Chert & |Unknown & Debitage & Tertiary Flake & Distal Fragment & na & na & na & na & na & na \\
\hline 64.5 & 96 & 5 & & 3 & & $40-50$ & & 74 & 50 & 1 & & Prehistoric & Metaquartzite & Unknown & Debitage & Primary Flake & Proximal Fragment & $\begin{array}{l}\text { Thermally } \\
\text { Altered }\end{array}$ & na & na & na & na & na \\
\hline 64.6 & 96 & 5 & & 3 & & 40-50 & & 74 & 50 & 1 & & Prehistoric & Metaquartzite & Unknown & Debitage & Primary Flake & Complete & na & na & na & na & na & na \\
\hline 64.7 & 96 & 5 & & 3 & & $40-50$ & & 74 & 50 & 3 & & Prehistoric & Metaquartzite & Unknown & Debitage & $\begin{array}{l}\text { Secondary } \\
\text { Flake }\end{array}$ & Proximal Fragment & $\begin{array}{l}\text { Thermally } \\
\text { Altered }\end{array}$ & na & na & na & na & na \\
\hline 64.8 & 96 & 5 & & 3 & & $40-50$ & & 74 & 50 & 4 & & Prehistoric & Metaquartzite & |Unknown & Debitage & $\begin{array}{l}\text { Secondary } \\
\text { Flake }\end{array}$ & Medial Fragment & $\begin{array}{l}\text { Thermally } \\
\text { Altered }\end{array}$ & na & na & na & na & na \\
\hline 64.9 & 96 & 5 & & 3 & & $40-50$ & & 74 & 50 & 1 & & Prehistoric & Metaquartzite & Unknown & Debitage & $\begin{array}{l}\text { Secondary } \\
\text { Flake }\end{array}$ & Medial Fragment & na & na & na & na & na & na \\
\hline 65.1 & 98 & 5 & & 4 & & 50-60 & & 74 & 50 & 1 & & Prehistoric & Chert & Unknown & Debitage & $\begin{array}{l}\text { Secondary } \\
\text { Flake }\end{array}$ & Complete & $\begin{array}{l}\text { Thermally } \\
\text { Altered }\end{array}$ & na & na & na & na & na \\
\hline 65.10 & 98 & 5 & & 4 & & 50-60 & & 74 & 50 & 2 & & Prehistoric & Metaquartzite & Unknown & Debitage & $\begin{array}{l}\text { Secondary } \\
\text { Flake }\end{array}$ & Distal Fragment & na & na & na & na & na & na \\
\hline 65.11 & 98 & 5 & & 4 & & 50-60 & & 74 & 50 & 2 & & Prehistoric & Metaquartzite & Unknown & Debitage & Tertiary Flake & Proximal Fragment & $\begin{array}{l}\text { Thermally } \\
\text { Altered }\end{array}$ & na & na & na & na & na \\
\hline 65.12 & 98 & 5 & & 4 & & 50-60 & & 74 & 50 & 4 & & Prehistoric & Metaquartzite & Unknown & Debitage & Tertiary Flake & Medial Fragment & $\begin{array}{l}\text { Thermally } \\
\text { Altered }\end{array}$ & na & na & na & na & na \\
\hline 65.13 & 98 & 5 & & 4 & & $50-60$ & & 74 & 50 & 1 & & Prehistoric & Metaquartzite & | Unknown & Debitage & Tertiary Flake & Medial Fragment & na & na & na & na & na & na \\
\hline 65.14 & 98 & 5 & & 4 & & $50-60$ & & 74 & 50 & 2 & & Prehistoric & Metaquartzite & Unknown & Debitage & Tertiary Flake & Distal Fragment & $\begin{array}{l}\text { Thermally } \\
\text { Altered }\end{array}$ & na & na & na & na & na \\
\hline 65.15 & 98 & 5 & & 4 & & 50-60 & & 74 & 50 & 1 & & Prehistoric & Silicified Wood & | Unknown & Debitage & Primary Flake & Proximal Fragment & na & na & na & na & na & na \\
\hline 65.16 & 98 & 5 & & 4 & & 50-60 & & 74 & 50 & 1 & & Prehistoric & Silicified Wood & Unknown & \begin{tabular}{|l|l|} 
Debitage \\
\end{tabular} & Primary Flake & Medial Fragment & na & na & na & na & na & na \\
\hline 65.17 & 98 & 5 & & 4 & & $\begin{array}{l}50-60 \\
\end{array}$ & & 74 & 50 & 4 & & Prehistoric & Silicified Wood & Unknown & Debitage & $\begin{array}{l}\text { Secondary } \\
\text { Flake }\end{array}$ & Proximal Fragment & $\begin{array}{l}\text { Thermally } \\
\text { Altered }\end{array}$ & na & na & na & na & na \\
\hline 65.18 & 98 & 5 & & 4 & & $50-60$ & & 74 & 50 & 5 & & Prehistoric & Silicified Wood & Unknown & Debitage & $\begin{array}{l}\text { Secondary } \\
\text { Flake }\end{array}$ & Proximal Fragment & na & na & na & na & na & na \\
\hline 65.19 & 98 & 5 & & 4 & & $50-60$ & & 74 & 50 & 1 & & Prehistoric & Silicified Wood & Unknown & Debitage & $\begin{array}{l}\text { Secondary } \\
\text { Flake }\end{array}$ & Medial Fragment & $\begin{array}{l}\text { Thermally } \\
\text { Altered }\end{array}$ & na & na & na & na & na \\
\hline 65.2 & 98 & 5 & & 4 & & $50-60$ & & 74 & 50 & 1 & & Prehistoric & Chert & Unknown & Debitage & \begin{tabular}{|l} 
Secondary \\
Flake
\end{tabular} & Proximal Fragment & na & na & na & na & na & na \\
\hline 65.20 & 98 & 5 & & 4 & & $50-60$ & & 74 & 50 & 3 & & Prehistoric & Silicified Wood & Unknown & Debitage & $\begin{array}{l}\text { Secondary } \\
\text { Flake }\end{array}$ & Medial Fragment & na & na & na & na & na & na \\
\hline 65.21 & 98 & 5 & & 4 & & $\begin{array}{l}50-60 \\
\end{array}$ & & 74 & 50 & 2 & & Prehistoric & Silicified Wood & Unknown & \begin{tabular}{|l} 
Debitage \\
\end{tabular} & $\begin{array}{l}\begin{array}{l}\text { Secondary } \\
\text { Flake }\end{array} \\
\end{array}$ & Distal Fragment & $\begin{array}{l}\text { Thermally } \\
\text { Altered }\end{array}$ & na & na & na & na & na \\
\hline 65.22 & 98 & 5 & & 4 & & $50-60$ & & 74 & 50 & 1 & & Prehistoric & Silicified Wood & |Unknown & \begin{tabular}{|l|l|} 
Debitage \\
\end{tabular} & $\begin{array}{l}\text { Secondary } \\
\text { Flake }\end{array}$ & Distal Fragment & na & na & na & na & na & na \\
\hline 65.23 & 98 & 5 & & 4 & & $50-60$ & & 74 & 50 & 1 & & Prehistoric & Metaquartzite & |Unknown & \begin{tabular}{|l|l|} 
Debitage \\
\end{tabular} & Tertiary Flake & Proximal Fragment & na & na & na & na & na & na \\
\hline 65.24 & 98 & 5 & & 4 & & $\begin{array}{l}50-60 \\
\end{array}$ & & 74 & 50 & 1 & & Prehistoric & Silicified Wood & Unknown & Debitage & Tertiary Flake & Complete & na & na & na & na & na & na \\
\hline 65.25 & 98 & 5 & & 4 & & 50-60 & & 74 & 50 & 3 & & Prehistoric & Silicified Wood & Unknown & Debitage & Tertiary Flake & Medial Fragment & na & na & na & na & na & 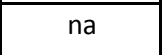 \\
\hline
\end{tabular}




\begin{tabular}{|c|c|c|c|c|c|c|c|c|c|c|c|c|c|c|c|c|c|c|c|c|c|c|c|}
\hline Lot No. & FS No. & \begin{tabular}{|l} 
Unit \\
No.
\end{tabular} & \begin{tabular}{|l|} 
ST \\
No. \\
\end{tabular} & Level & \begin{tabular}{|l} 
Depth \\
(cmbs) \\
\end{tabular} & $\begin{array}{l}\text { Depth } \\
\text { (cmbd) }\end{array}$ & Provience & Northing & Easting & $\begin{array}{c}\text { No. of } \\
\text { Specimens }\end{array}$ & $\begin{array}{c}\text { Time } \\
\text { Period }\end{array}$ & Era/Phase & Artifact Material & Use Context & $\begin{array}{c}\text { Artifact } \\
\text { Description }\end{array}$ & $\begin{array}{l}\text { Artifact Sub- } \\
\text { description }\end{array}$ & $\begin{array}{c}\text { Artifact } \\
\text { Form/Condition }\end{array}$ & $\begin{array}{c}\text { Surface } \\
\text { Treatment }\end{array}$ & Comments & $\begin{array}{l}\text { Weight in } \\
\text { grams }\end{array}$ & $\begin{array}{c}\text { Length in } \\
\mathrm{mm}\end{array}$ & $\begin{array}{c}\text { Width in } \\
\mathrm{mm}\end{array}$ & $\begin{array}{c}\text { Thickness in } \\
\mathrm{mm}\end{array}$ \\
\hline 65.26 & 98 & 5 & & 4 & & $50-60$ & & 74 & 50 & 2 & & Prehistoric & Silicified Wood & \begin{tabular}{|l|l|} 
Unknown \\
\end{tabular} & \begin{tabular}{|l|} 
Debitage \\
\end{tabular} & \begin{tabular}{|l|} 
Tertiary Flake \\
\end{tabular} & Distal Fragment & na & na & na & na & na & na \\
\hline \begin{tabular}{|l|l|}
65.28 \\
\end{tabular} & 98 & 5 & & 4 & & $50-60$ & & 74 & 50 & 1 & & Prehistoric & Orthoquartzite & Unknown & Debitage & $\begin{array}{l}\text { Secondary } \\
\text { Flake }\end{array}$ & Distal Fragment & $\begin{array}{l}\text { Thermally } \\
\text { Altered }\end{array}$ & na & na & na & na & na \\
\hline 65.29 & 98 & 5 & & 4 & & $50-60$ & & 74 & 50 & 1 & & Prehistoric & Chert & Unknown & Debitage & $\begin{array}{l}\text { Secondary } \\
\text { Flake }\end{array}$ & \begin{tabular}{|l|} 
Proximal Fragment \\
\end{tabular} & \begin{tabular}{|l|}
$\begin{array}{l}\text { Thermally } \\
\text { Altered }\end{array}$ \\
\end{tabular} & na & na & na & na & na \\
\hline 65.3 & 98 & 5 & & 4 & & $50-60$ & & 74 & 50 & 1 & & Prehistoric & Chert & Unknown & Debitage & $\begin{array}{l}\text { Secondary } \\
\text { Flake }\end{array}$ & Distal Fragment & \begin{tabular}{|l} 
Thermally \\
Altered
\end{tabular} & na & na & na & na & na \\
\hline 65.30 & 98 & 5 & & 4 & & $50-60$ & & 74 & 50 & 1 & & Prehistoric & Metaquartzite & Unknown & Debitage & $\begin{array}{l}\text { Secondary } \\
\text { Flake }\end{array}$ & Complete & $\begin{array}{l}\text { Thermally } \\
\text { Altered }\end{array}$ & na & na & na & na & na \\
\hline 65.31 & 98 & 5 & & 4 & & $50-60$ & & 74 & 50 & 3 & & Prehistoric & Silicified Wood & Unknown & Debitage & $\begin{array}{l}\text { Secondary } \\
\text { Flake }\end{array}$ & Complete & na & na & na & na & na & na \\
\hline 65.4 & 98 & 5 & & 4 & & $50-60$ & & 74 & 50 & 1 & & Prehistoric & Chert & Unknown & Debitage & Tertiary Flake & Complete & na & na & na & na & na & na \\
\hline 65.5 & 98 & 5 & & 4 & & $50-60$ & & 74 & 50 & 1 & & Prehistoric & Metaquartzite & Unknown & Debitage & Primary Flake & \begin{tabular}{|l|} 
Proximal Fragment \\
\end{tabular} & \begin{tabular}{|l|} 
Thermally \\
Altered
\end{tabular} & na & na & na & na & na \\
\hline 65.6 & 98 & 5 & & 4 & & $50-60$ & & 74 & 50 & 1 & & Prehistoric & Metaquartzite & Unknown & Debitage & \begin{tabular}{|l|} 
Primary Flake \\
\end{tabular} & \begin{tabular}{|l} 
Medial Fragment \\
\end{tabular} & $\begin{array}{l}\text { Thermally } \\
\text { Altered }\end{array}$ & na & na & na & na & na \\
\hline 65.7 & 98 & 5 & & 4 & & $50-60$ & & 74 & 50 & 3 & & Prehistoric & Metaquartzite & Unknown & Debitage & \begin{tabular}{|l} 
Secondary \\
Flake
\end{tabular} & Proximal Fragment & \begin{tabular}{|l} 
Thermally \\
Altered
\end{tabular} & na & na & na & na & na \\
\hline 65.8 & 98 & 5 & & 4 & & 50-60 & & 74 & 50 & 2 & & Prehistoric & Metaquartzite & Unknown & Debitage & $\begin{array}{l}\text { Secondary } \\
\text { Flake }\end{array}$ & Medial Fragment & $\begin{array}{l}\text { Thermally } \\
\text { Altered }\end{array}$ & na & na & na & na & na \\
\hline 65.9 & 98 & 5 & & 4 & & $50-60$ & & 74 & 50 & 3 & & Prehistoric & Metaquartzite & Unknown & Debitage & $\begin{array}{l}\text { Secondary } \\
\text { Flake }\end{array}$ & Distal Fragment & \begin{tabular}{|l}
$\begin{array}{l}\text { Thermally } \\
\text { Altered }\end{array}$ \\
\end{tabular} & na & na & na & na & na \\
\hline 66.1 & 99 & 5 & & 5 & & $60-70$ & & 74 & 50 & 1 & & Prehistoric & Chert & Unknown & Debitage & \begin{tabular}{|l} 
Secondary \\
Flake
\end{tabular} & \begin{tabular}{|l} 
Medial Fragment \\
\end{tabular} & \begin{tabular}{|l} 
Thermally \\
Altered
\end{tabular} & na & na & na & na & na \\
\hline 66.10 & 99 & 5 & & 5 & & $60-70$ & & 74 & 50 & 1 & & Prehistoric & Metaquartzite & Unknown & Debitage & Tertiary Flake & Medial Fragment & na & na & na & $\mathrm{na}$ & na & na \\
\hline 66.11 & 99 & 5 & & 5 & & $60-70$ & & 74 & 50 & 1 & & Prehistoric & Orthoquartzite & Unknown & Debitage & \begin{tabular}{|l} 
Secondary \\
Flake
\end{tabular} & Distal Fragment & \begin{tabular}{|l} 
Thermally \\
Altered
\end{tabular} & na & na & na & na & na \\
\hline 66.12 & 99 & 5 & & 5 & & $60-70$ & & 74 & 50 & 1 & & Prehistoric & Orthoquartzite & Unknown & Debitage & \begin{tabular}{|l|} 
Tertiary Flake \\
\end{tabular} & Medial Fragment & \begin{tabular}{|l|} 
Thermally \\
Altered
\end{tabular} & na & na & na & na & na \\
\hline 66.13 & 99 & 5 & & 5 & & $60-70$ & & 74 & 50 & 1 & & Prehistoric & Orthoquartzite & Unknown & Debitage & Tertiary Flake & Distal Fragment & $\begin{array}{l}\text { Thermally } \\
\text { Altered }\end{array}$ & na & na & na & na & na \\
\hline 66.14 & 99 & 5 & & 5 & & $60-70$ & & 74 & 50 & 1 & & Prehistoric & Silicified Wood & Unknown & Debitage & $\begin{array}{l}\text { Secondary } \\
\text { Flake }\end{array}$ & 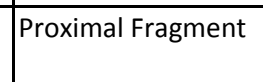 & \begin{tabular}{|l} 
Thermally \\
Altered
\end{tabular} & na & na & na & na & na \\
\hline 66.15 & 99 & 5 & & 5 & & $60-70$ & & 74 & 50 & 2 & & Prehistoric & Silicified Wood & Unknown & Debitage & $\begin{array}{l}\text { Secondary } \\
\text { Flake }\end{array}$ & \begin{tabular}{|l} 
Medial Fragment \\
\end{tabular} & na & na & na & na & na & na \\
\hline 66.16 & 99 & 5 & & 5 & & $60-70$ & & 74 & 50 & 1 & & Prehistoric & Silicified Wood & Unknown & Debitage & $\begin{array}{l}\text { Secondary } \\
\text { Flake }\end{array}$ & \begin{tabular}{|l|} 
Proximal Fragment \\
troximal Fragent
\end{tabular} & na & na & na & na & na & na \\
\hline $\begin{array}{ll}66.17 \\
\end{array}$ & 99 & 5 & & 5 & & $60-70$ & & 74 & 50 & 1 & & Prehistoric & Silicified Wood & Unknown & Debitage & $\begin{array}{l}\text { Secondary } \\
\text { Flake }\end{array}$ & Distal Fragment & na & na & na & na & na & na \\
\hline $\begin{array}{ll}66.18 \\
\end{array}$ & 99 & 5 & & 5 & & $60-70$ & & 74 & 50 & 1 & & Prehistoric & Silicified Wood & Unknown & Debitage & Tertiary Flake & Complete & na & na & na & na & na & na \\
\hline 66.19 & 99 & 5 & & 5 & & $60-70$ & & 74 & 50 & 1 & & Prehistoric & Silicified Wood & Unknown & Debitage & Tertiary Flake & Medial Fragment & $\begin{array}{l}\text { Thermally } \\
\text { Altered }\end{array}$ & na & na & na & na & na \\
\hline 66.2 & 99 & 5 & & 5 & & $60-70$ & & 74 & 50 & 1 & & Prehistoric & Chert & Unknown & Debitage & $\begin{array}{l}\text { Secondary } \\
\text { Flake }\end{array}$ & Distal Fragment & na & na & na & na & na & na \\
\hline 66.20 & 99 & 5 & & 5 & & $60-70$ & & 74 & 50 & 2 & & Prehistoric & Silicified Wood & Unknown & Debitage & Tertiary Flake & Distal Fragment & \begin{tabular}{|l|} 
Thermally \\
Altered
\end{tabular} & na & na & na & na & na \\
\hline 66.21 & 99 & 5 & & 5 & & $60-70$ & & 74 & 50 & 2 & & Prehistoric & Silicified Wood & Unknown & Debitage & Tertiary Flake & Distal Fragment & na & na & na & na & na & na \\
\hline 66.22 & 99 & 5 & & 5 & & $60-70$ & & 74 & 50 & 1 & & Prehistoric & Orthoquartzite & Unknown & Debitage & $\begin{array}{l}\text { Secondary } \\
\text { Flake }\end{array}$ & 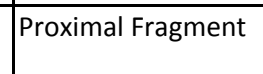 & na & na & na & na & na & na \\
\hline
\end{tabular}




\begin{tabular}{|c|c|c|c|c|c|c|c|c|c|c|c|c|c|c|c|c|c|c|c|c|c|c|c|}
\hline Lot No. & FS No. & \begin{tabular}{|l} 
Unit \\
No.
\end{tabular} & \begin{tabular}{|l|} 
ST \\
No. \\
\end{tabular} & Level & \begin{tabular}{|l} 
Depth \\
(cmbs) \\
\end{tabular} & $\begin{array}{l}\text { Depth } \\
\text { (cmbd) }\end{array}$ & Provience & Northing & Easting & $\begin{array}{c}\text { No. of } \\
\text { Specimens }\end{array}$ & $\begin{array}{c}\text { Time } \\
\text { Period }\end{array}$ & Era/Phase & Artifact Material & Use Context & $\begin{array}{c}\text { Artifact } \\
\text { Description }\end{array}$ & $\begin{array}{l}\text { Artifact Sub- } \\
\text { description }\end{array}$ & $\begin{array}{c}\text { Artifact } \\
\text { Form/Condition }\end{array}$ & $\begin{array}{c}\text { Surface } \\
\text { Treatment }\end{array}$ & Comments & $\begin{array}{l}\text { Weight in } \\
\text { grams }\end{array}$ & $\begin{array}{c}\text { Length in } \\
\mathrm{mm}\end{array}$ & $\begin{array}{c}\text { Width in } \\
\mathrm{mm}\end{array}$ & $\begin{array}{c}\text { Thickness in } \\
\mathrm{mm}\end{array}$ \\
\hline 66.23 & 99 & \begin{tabular}{|c|} 
No. \\
5
\end{tabular} & & \begin{tabular}{|l|}
5 \\
5
\end{tabular} & & 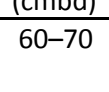 & $\begin{array}{l}\text { roviente } \\
\end{array}$ & 74 & $\frac{\operatorname{casting}}{50}$ & 3 & & \begin{tabular}{|l|} 
Ereh/istoric \\
Prehic
\end{tabular} & Silicified Wood & \begin{tabular}{|l} 
Une colmext \\
Unknown
\end{tabular} & Debitage & $\begin{array}{l}\text { Secondary } \\
\text { Flake }\end{array}$ & \begin{tabular}{|l|l|} 
Complete \\
\end{tabular} & na & Comments & na & na & na & na \\
\hline 66.24 & 99 & 5 & & 5 & & $60-70$ & & 74 & 50 & 1 & & Prehistoric & Silicified Wood & Unknown & Debitage & Tertiary Flake & \begin{tabular}{|l} 
Medial Fragment \\
\end{tabular} & na & na & na & na & na & na \\
\hline 66.3 & 99 & 5 & & 5 & & $60-70$ & & 74 & 50 & 1 & & Prehistoric & Chert & Unknown & Debitage & Tertiary Flake & Distal Fragment & \begin{tabular}{|l|} 
Thermally \\
Altered
\end{tabular} & na & na & na & na & na \\
\hline 66.4 & 99 & 5 & & 5 & & $60-70$ & & 74 & 50 & 1 & & Prehistoric & Metaquartzite & Unknown & Debitage & $\begin{array}{l}\text { Secondary } \\
\text { Flake }\end{array}$ & Proximal Fragment & \begin{tabular}{|l|} 
Thermally \\
Altered
\end{tabular} & na & na & na & na & na \\
\hline 66.5 & 99 & 5 & & 5 & & $60-70$ & & 74 & 50 & 2 & & Prehistoric & Metaquartzite & Unknown & Debitage & $\begin{array}{l}\text { Secondary } \\
\text { Flake }\end{array}$ & \begin{tabular}{|l} 
Medial Fragment \\
\end{tabular} & $\begin{array}{l}\text { Thermally } \\
\text { Altered }\end{array}$ & na & na & na & na & na \\
\hline 66.6 & 99 & 5 & & 5 & & $60-70$ & & 74 & 50 & 1 & & Prehistoric & Metaquartzite & Unknown & Debitage & $\begin{array}{l}\text { Secondary } \\
\text { Flake }\end{array}$ & Proximal Fragment & na & na & na & na & na & na \\
\hline 66.7 & 99 & 5 & & 5 & & $60-70$ & & 74 & 50 & 1 & & Prehistoric & Metaquartzite & Unknown & Debitage & $\begin{array}{l}\text { Secondary } \\
\text { Flake }\end{array}$ & Distal Fragment & \begin{tabular}{|l|} 
Thermally \\
Altered
\end{tabular} & na & na & na & na & na \\
\hline $\begin{array}{l}66.8 \\
\end{array}$ & 99 & 5 & & 5 & & $60-70$ & & 74 & 50 & 1 & & Prehistoric & Metaquartzite & Unknown & Debitage & Tertiary Flake & 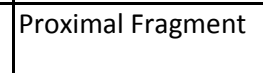 & $\begin{array}{l}\text { Thermally } \\
\text { Altered }\end{array}$ & na & na & na & na & na \\
\hline 66.9 & 99 & 5 & & 5 & & $60-70$ & & 74 & 50 & 1 & & Prehistoric & Metaquartzite & Unknown & Debitage & Tertiary Flake & \begin{tabular}{|l} 
Medial Fragment \\
\end{tabular} & $\begin{array}{l}\text { Thermally } \\
\text { Altered }\end{array}$ & na & na & na & na & na \\
\hline 67.1 & 100 & 5 & & 6 & & $70-80$ & & 74 & 50 & 1 & & Prehistoric & Chert & Unknown & Debitage & $\begin{array}{l}\text { Secondary } \\
\text { Flake }\end{array}$ & \begin{tabular}{|l} 
Medial Fragment \\
\end{tabular} & \begin{tabular}{|l|} 
Thermally \\
Altered
\end{tabular} & na & na & na & na & na \\
\hline 67.10 & 100 & 5 & & 6 & & $70-80$ & & 74 & 50 & 1 & & Prehistoric & Silicified Wood & Unknown & Debitage & $\begin{array}{l}\text { Secondary } \\
\text { Flake }\end{array}$ & Proximal Fragment & $\begin{array}{l}\text { Thermally } \\
\text { Altered }\end{array}$ & na & na & na & na & na \\
\hline 67.11 & 100 & 5 & & 6 & & $70-80$ & & 74 & 50 & 1 & & Prehistoric & Silicified Wood & Unknown & Debitage & $\begin{array}{l}\text { Secondary } \\
\text { Flake }\end{array}$ & Complete & na & na & na & na & na & na \\
\hline 67.12 & 100 & 5 & & 6 & & $70-80$ & & 74 & 50 & 1 & & Prehistoric & Silicified Wood & Unknown & Debitage & $\begin{array}{l}\text { Secondary } \\
\text { Flake }\end{array}$ & Distal Fragment & \begin{tabular}{|l|} 
Thermally \\
Altered
\end{tabular} & na & na & na & na & na \\
\hline 67.13 & 100 & 5 & & 6 & & $70-80$ & & 74 & 50 & 2 & & Prehistoric & Silicified Wood & Unknown & Debitage & $\begin{array}{l}\text { Secondary } \\
\text { Flake }\end{array}$ & Distal Fragment & na & na & na & na & na & na \\
\hline 67.14 & 100 & 5 & & 6 & & $70-80$ & & 74 & 50 & 1 & & Prehistoric & Silicifified Wood & Unknown & Debitage & \begin{tabular}{|l} 
Tertiary Flake \\
\end{tabular} & \begin{tabular}{|l} 
Proximal Fragment \\
\end{tabular} & na & na & na & na & na & na \\
\hline 67.15 & 100 & 5 & & 6 & & $70-80$ & & 74 & 50 & 2 & & Prehistoric & Silicified Wood & Unknown & Debitage & Tertiary Flake & \begin{tabular}{|l} 
Medial Fragment \\
\end{tabular} & na & na & na & na & na & na \\
\hline 67.2 & 100 & 5 & & 6 & & $70-80$ & & 74 & 50 & 1 & & Prehistoric & Chert & Unknown & Debitage & \begin{tabular}{|l} 
Secondary \\
Flake
\end{tabular} & Proximal Fragment & \begin{tabular}{|l|} 
Thermally \\
Altered
\end{tabular} & na & na & na & na & na \\
\hline 67.3 & 100 & 5 & & 6 & & $70-80$ & & 74 & 50 & 1 & & Prehistoric & Chert & Unknown & Debitage & Tertiary Flake & Complete & na & na & na & na & na & na \\
\hline 67.4 & 100 & 5 & & 6 & & $70-80$ & & 74 & 50 & 1 & & Prehistoric & Metaquartzite & Unknown & Debitage & Primary Flake & Medial Fragment & \begin{tabular}{|l|} 
Thermally \\
Altered
\end{tabular} & na & na & na & na & na \\
\hline 67.5 & 100 & 5 & & 6 & & $70-80$ & & 74 & 50 & 1 & & Prehistoric & Metaquartzite & Unknown & Debitage & $\begin{array}{l}\text { Secondary } \\
\text { Flake }\end{array}$ & \begin{tabular}{|l|} 
Proximal Fragment \\
troximal Fragent
\end{tabular} & \begin{tabular}{|l|} 
Thermally \\
Altered
\end{tabular} & na & na & na & na & na \\
\hline 67.6 & 100 & 5 & & 6 & & $70-80$ & & 74 & 50 & 1 & & Prehistoric & Metaquartzite & Unknown & Debitage & $\begin{array}{l}\text { Secondary } \\
\text { Flake }\end{array}$ & 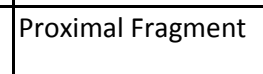 & na & na & na & na & na & na \\
\hline 67.7 & 100 & 5 & & 6 & & $70-80$ & & 74 & 50 & 1 & & Prehistoric & Metaquartzite & Unknown & Debitage & Tertiary Flake & \begin{tabular}{|l} 
Medial Fragment \\
\end{tabular} & \begin{tabular}{|l|}
$\begin{array}{l}\text { Thermally } \\
\text { Altered }\end{array}$ \\
\end{tabular} & na & na & na & na & na \\
\hline 67.8 & 100 & 5 & & 6 & & $70-80$ & & 74 & 50 & 1 & & Prehistoric & Orthoquartzite & Unknown & Debitage & Primary Flake & Distal Fragment & \begin{tabular}{|l|}
$\begin{array}{l}\text { Thermally } \\
\text { Altered }\end{array}$ \\
\end{tabular} & na & na & na & na & na \\
\hline 67.9 & 100 & 5 & & 6 & & $70-80$ & & 74 & 50 & 1 & & Prehistoric & Orthoquartzite & Unknown & Debitage & Tertiary Flake & Proximal Fragment & \begin{tabular}{|l|} 
Thermally \\
Altered
\end{tabular} & na & na & na & na & na \\
\hline 68.1 & 85 & 6 & & 2 & & $20-30$ & & 67 & 62.5 & 1 & & Prehistoric & Chert & Unknown & Debitage & Primary Flake & Complete & $\begin{array}{l}\text { Thermally } \\
\text { Altered }\end{array}$ & na & na & na & na & na \\
\hline 68.2 & 85 & 6 & & 2 & & $20-30$ & & 67 & 62.5 & 2 & & Prehistoric & Metaquartzite & Unknown & Debitage & $\begin{array}{l}\text { Secondary } \\
\text { Flake }\end{array}$ & Medial Fragment & \begin{tabular}{|l|}
$\begin{array}{l}\text { Thermally } \\
\text { Altered }\end{array}$ \\
\end{tabular} & na & na & na & na & na \\
\hline 68.3 & 85 & 6 & & 2 & & $20-30$ & & 67 & 62.5 & 1 & & Prehistoric & Metaquartzite & Unknown & Debitage & $\begin{array}{l}\text { Secondary } \\
\text { Flake }\end{array}$ & 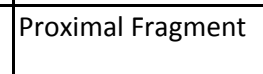 & na & na & na & na & na & na \\
\hline
\end{tabular}




\begin{tabular}{|c|c|c|c|c|c|c|c|c|c|c|c|c|c|c|c|c|c|c|c|c|c|c|c|}
\hline Lot No. & FS No. & $\begin{array}{l}\text { Unit } \\
\text { No. }\end{array}$ & $\begin{array}{l}\text { ST } \\
\text { No. }\end{array}$ & Level & $\begin{array}{l}\text { Depth } \\
\text { (cmbs) }\end{array}$ & $\begin{array}{l}\text { Depth } \\
\text { (cmbd) }\end{array}$ & Provience & Northing & Easting & \begin{tabular}{|c|} 
No. of \\
Specimens
\end{tabular} & $\begin{array}{l}\text { Time } \\
\text { Period }\end{array}$ & Era/ Phase & Artifact Material & Use Context & $\begin{array}{c}\text { Artifact } \\
\text { Description }\end{array}$ & $\begin{array}{c}\text { Artifact Sub- } \\
\text { description }\end{array}$ & $\begin{array}{c}\text { Artifact } \\
\text { Form/Condition }\end{array}$ & \begin{tabular}{|c} 
Surface \\
Treatment
\end{tabular} & Comments & $\begin{array}{l}\text { Weight in } \\
\text { grams }\end{array}$ & $\begin{array}{l}\text { Length in } \\
\mathrm{mm}\end{array}$ & $\begin{array}{l}\text { Width in } \\
\mathrm{mm}\end{array}$ & \begin{tabular}{|c|} 
Thickness in \\
$\mathrm{mm}$
\end{tabular} \\
\hline $\begin{array}{ll}68.4 \\
\end{array}$ & 85 & 6 & & 2 & & $20-30$ & & 67 & 62.5 & 1 & & Prehistoric & Metaquartzite & Unknown & Debitage & $\begin{array}{l}\text { Secondary } \\
\text { Flake }\end{array}$ & Proximal Fragment & \begin{tabular}{|l} 
Thermally \\
Altered
\end{tabular} & na & na & na & na & na \\
\hline 69.1 & 86 & 6 & & 3 & & $30-40$ & & 67 & 62.5 & 1 & & Prehistoric & Chert & Unknown & Debitage & \begin{tabular}{|l|} 
Tertiary Flake \\
\end{tabular} & Complete & na & na & na & na & na & na \\
\hline 69.2 & 86 & 6 & & 3 & & $30-40$ & & 67 & 62.5 & 1 & & Prehistoric & Chert & Unknown & Debitage & \begin{tabular}{|l|} 
Tertiary Flake \\
\end{tabular} & Medial Fragment & na & na & na & na & na & na \\
\hline 69.3 & 86 & 6 & & 3 & & $30-40$ & & 67 & 62.5 & 1 & & Prehistoric & Orthoquartzite & Unknown & Debitage & \begin{tabular}{|l|} 
Tertiary Flake \\
\end{tabular} & Proximal Fragment & $\begin{array}{l}\text { Thermally } \\
\text { Altered }\end{array}$ & na & na & na & na & na \\
\hline 69.4 & 86 & 6 & & 3 & & $30-40$ & & 67 & 62.5 & 1 & & Prehistoric & Silicified Wood & Unknown & Debitage & \begin{tabular}{|l|} 
Tertiary Flake \\
\end{tabular} & Medial Fragment & na & na & na & na & na & na \\
\hline 70 & 104 & 6 & & 6 & & 60-70 & SE corner & 67 & 62.5 & 1 & & Prehistoric & Metaquartzite & Unknown & Dart Point & Gary & Complete & $\begin{array}{l}\text { Thermally } \\
\text { Altered }\end{array}$ & \begin{tabular}{|l|} 
Reworked, convex basal edge, \\
expanding stem, small but distinct \\
shoulders, very small triangular \\
shaped body, straight lateral \\
edges, well thinned across \\
entirety of specimen, slight \\
medial ridge on single face, stem \\
is longer than body of specimen, \\
high polish on distal tip indicative \\
of use for perforation on a soft \\
material
\end{tabular} & 1.76 & 21.76 & 15.46 & 5.92 \\
\hline 71.1 & 105 & 6 & & 7 & & $70-80$ & & 67 & 62.5 & 1 & & Prehistoric & Chert & Unknown & Debitage & Primary Flake & Proximal Fragment & na & na & na & na & na & na \\
\hline 71.2 & 105 & 6 & & 7 & & $70-80$ & & 67 & 62.5 & 1 & & Prehistoric & Chert & Unknown & Debitage & Tertiary Flake & Distal Fragment & na & na & na & na & na & na \\
\hline 71.3 & 105 & 6 & & 7 & & $70-80$ & & 67 & 62.5 & 1 & & Prehistoric & Metaquartzite & Unknown & Debitage & $\begin{array}{l}\text { Secondary } \\
\text { Flake }\end{array}$ & Proximal Fragment & na & na & na & na & na & na \\
\hline 72.1 & 88 & 7 & & 3 & & $30-40$ & & 67 & 59 & 1 & & Prehistoric & Chert & Unknown & Debitage & $\begin{array}{l}\text { Secondary } \\
\text { Flake }\end{array}$ & Proximal Fragment & \begin{tabular}{|l|} 
Thermally \\
Altered
\end{tabular} & na & na & na & na & na \\
\hline 72.2 & 88 & 7 & & 3 & & $30-40$ & & 67 & 59 & 1 & & Prehistoric & Chert & Unknown & Debitage & Tertiary Flake & Complete & na & na & na & na & na & na \\
\hline 72.3 & 88 & 7 & & 3 & & $30-40$ & & 67 & 59 & 1 & & Prehistoric & Chert & Unknown & Debitage & Tertiary Flake & Proximal Fragment & $\begin{array}{l}\text { Thermally } \\
\text { Altered }\end{array}$ & na & na & na & na & na \\
\hline 72.4 & 88 & 7 & & 3 & & $30-40$ & & 67 & 59 & 3 & & Prehistoric & Metaquartzite & Unknown & Debitage & Tertiary Flake & Medial Fragment & $\begin{array}{l}\text { Thermally } \\
\text { Altered }\end{array}$ & na & na & na & na & na \\
\hline 72.5 & 88 & 7 & & 3 & & $30-40$ & & 67 & 59 & 1 & & Prehistoric & Metaquartzite & Unknown & Debitage & Tertiary Flake & Distal Fragment & \begin{tabular}{|l|} 
Thermally \\
Altered
\end{tabular} & na & na & na & na & na \\
\hline 73.1 & 89 & 7 & & 4 & & $\begin{array}{ll}40-50 \\
\end{array}$ & & 67 & 59 & 2 & & Prehistoric & Chert & Unknown & Debitage & Tertiary Flake & Proximal Fragment & na & na & na & na & na & na \\
\hline 73.2 & 89 & 7 & & 4 & & $40-50$ & & 67 & 59 & 1 & & Prehistoric & Silicified Wood & Unknown & Debitage & Tertiary Flake & Complete & $\begin{array}{l}\text { Thermally } \\
\text { Altered }\end{array}$ & na & na & na & na & na \\
\hline 73.3 & 89 & 7 & & 4 & & $40-50$ & & 67 & 59 & 1 & & Prehistoric & Silicified Wood & Unknown & Debitage & Tertiary Flake & Medial Fragment & na & na & na & na & na & na \\
\hline 73.4 & 89 & 7 & & 4 & & $40-50$ & & 67 & 59 & 1 & & Prehistoric & Silicified Wood & Unknown & Debitage & Tertiary Flake & Distal Fragment & na & na & na & na & na & na \\
\hline 74.1 & 90 & 7 & & 5 & & $50-60$ & & 67 & 59 & 1 & & Prehistoric & Metaquartzite & Unknown & Debitage & \begin{tabular}{|l|} 
Secondary \\
Flake
\end{tabular} & Distal Fragment & $\begin{array}{l}\text { Thermally } \\
\text { Altered }\end{array}$ & na & na & na & na & na \\
\hline 74.2 & 90 & 7 & & 5 & & 50-60 & & 67 & 59 & 1 & & Prehistoric & Metaquartzite & Unknown & Debitage & Tertiary Flake & Medial Fragment & na & na & na & na & na & na \\
\hline 76.1 & 93 & 7 & & 6 & & $\begin{array}{ll}60-70 \\
\end{array}$ & & 67 & 59 & 1 & & Prehistoric & Chert & Unknown & Debitage & Tertiary Flake & Distal Fragment & na & na & na & na & na & na \\
\hline 76.2 & 93 & 7 & & 6 & & $60-70$ & & 67 & 59 & 1 & & Prehistoric & Novaculite & Unknown & Debitage & Tertiary Flake & Complete & na & na & na & na & na & na \\
\hline
\end{tabular}




\begin{tabular}{|c|c|c|c|c|c|c|c|c|c|c|c|c|c|c|c|c|c|c|c|c|c|c|c|}
\hline Lot No. & FS No. & $\begin{array}{l}\text { Unit } \\
\text { No. }\end{array}$ & $\begin{array}{l}\text { ST } \\
\text { No. }\end{array}$ & Level & $\begin{array}{l}\text { Depth } \\
\text { (cmbs) }\end{array}$ & $\begin{array}{l}\text { Depth } \\
\text { (cmbd) } \\
\end{array}$ & Provience & Northing & Easting & $\begin{array}{c}\begin{array}{c}\text { No. of } \\
\text { Specimens }\end{array} \\
\end{array}$ & $\begin{array}{c}\text { Time } \\
\text { Period } \\
\end{array}$ & Era/Phase & Artifact Material & Use Context & $\begin{array}{c}\text { Artifact } \\
\text { Description }\end{array}$ & $\begin{array}{c}\text { Artifact Sub- } \\
\text { description }\end{array}$ & $\begin{array}{l}\text { Artifact } \\
\text { Form/Condition }\end{array}$ & \begin{tabular}{|c|} 
Surface \\
Treatment
\end{tabular} & Comments & $\begin{array}{l}\text { Weight in } \\
\text { grams }\end{array}$ & $\begin{array}{l}\text { Length in } \\
\mathrm{mm}\end{array}$ & $\begin{array}{c}\text { Width in } \\
\mathrm{mm}\end{array}$ & \begin{tabular}{|c|} 
Thickness in \\
$\mathrm{mm}$
\end{tabular} \\
\hline 77.1 & 71 & 8 & & 1 & & $9-20$ & & 55 & 57 & 1 & & Prehistoric & Chert & Unknown & \begin{tabular}{|l|} 
Debitage \\
\end{tabular} & Tertiary Flake & Complete & na & na & na & na & na & na \\
\hline 77.2 & 71 & 8 & & 1 & & $9-20$ & & 55 & 57 & 1 & & Prehistoric & Chert & Unknown & Debitage & Tertiary Flake & Medial Fragment & na & na & na & na & na & na \\
\hline 78.1 & 73 & 8 & & 2 & & $20-30$ & & 55 & 57 & 1 & & Prehistoric & Chert & Unknown & Debitage & Tertiary Flake & Proximal Fragment & na & na & na & na & na & na \\
\hline 78.2 & 73 & 8 & & 2 & & $20-30$ & & 55 & 57 & 1 & & Prehistoric & Chert & Unknown & Debitage & Tertiary Flake & Distal Fragment & na & na & na & na & na & na \\
\hline 78.3 & 73 & 8 & & 2 & & $20-30$ & & 55 & 57 & 1 & & Prehistoric & Metaquartzite & Unknown & Debitage & \begin{tabular}{|l} 
Secondary \\
Flake
\end{tabular} & Proximal Fragment & $\begin{array}{l}\text { Thermally } \\
\text { Altered }\end{array}$ & na & na & na & na & na \\
\hline 78.4 & 73 & 8 & & 2 & & $20-30$ & & 55 & 57 & 1 & & Prehistoric & Metaquartzite & Unknown & Debitage & Tertiary Flake & Distal Fragment & $\begin{array}{l}\text { Thermally } \\
\text { Altered }\end{array}$ & na & na & na & na & na \\
\hline 78.5 & 73 & 8 & & 2 & & $20-30$ & & 55 & 57 & 1 & & Prehistoric & Metaquartzite & Unknown & Debitage & Tertiary Flake & Distal Fragment & na & na & na & na & na & na \\
\hline 78.6 & 73 & 8 & & 2 & & $20-30$ & & 55 & 57 & 1 & & Prehistoric & Silicified Wood & Unknown & Debitage & $\begin{array}{l}\text { Secondary } \\
\text { Flake }\end{array}$ & Proximal Fragment & na & na & na & na & na & na \\
\hline 78.7 & 73 & 8 & & 2 & & $20-30$ & & 55 & 57 & 1 & & Prehistoric & Silicified Wood & Unknown & Debitage & \begin{tabular}{|l}
$\begin{array}{l}\text { Secondary } \\
\text { Flake }\end{array}$ \\
\end{tabular} & Distal Fragment & $\begin{array}{l}\text { Thermally } \\
\text { Altered }\end{array}$ & na & na & na & na & na \\
\hline 80.1 & 75 & 8 & & 3 & & $30-40$ & & 55 & 57 & 1 & & Prehistoric & Chert & Unknown & Debitage & \begin{tabular}{|l|} 
Secondary \\
Flake
\end{tabular} & Proximal Fragment & $\begin{array}{l}\text { Thermally } \\
\text { Altered }\end{array}$ & na & na & na & na & na \\
\hline 80.2 & 75 & 8 & & 3 & & $30-40$ & & 55 & 57 & 1 & & Prehistoric & Chert & Unknown & Debitage & Tertiary Flake & Medial Fragment & na & na & na & na & na & na \\
\hline 80.3 & 75 & 8 & & 3 & & $30-40$ & & 55 & 57 & 1 & & Prehistoric & Chert & Unknown & Debitage & Tertiary Flake & Distal Fragment & na & na & na & na & na & na \\
\hline 80.4 & 75 & 8 & & 3 & & $30-40$ & & 55 & 57 & 1 & & Prehistoric & Metaquartzite & Unknown & Debitage & \begin{tabular}{|l} 
Secondary \\
Flake
\end{tabular} & Medial Fragment & $\begin{array}{l}\text { Thermally } \\
\text { Altered }\end{array}$ & na & na & na & na & na \\
\hline 80.5 & 75 & 8 & & 3 & & $30-40$ & & 55 & 57 & 1 & & Prehistoric & Metaquartzite & Unknown & Debitage & Tertiary Flake & Proximal Fragment & na & na & na & na & na & na \\
\hline 80.6 & 75 & 8 & & 3 & & $30-40$ & & 55 & 57 & 1 & & Prehistoric & Silicified Wood & Unknown & Debitage & Tertiary Flake & Distal Fragment & $\begin{array}{l}\text { Thermally } \\
\text { Altered }\end{array}$ & na & na & na & na & na \\
\hline 80.7 & 75 & 8 & & 3 & & $30-40$ & & 55 & 57 & 1 & & Prehistoric & Silicified Wood & Unknown & Debitage & Tertiary Flake & Proximal Fragment & na & na & na & na & na & na \\
\hline 81.1 & 79 & 8 & & 4 & & $40-50$ & & 55 & 57 & 1 & & Prehistoric & Chert & Unknown & Debitage & \begin{tabular}{|l|} 
Tertiary Flake \\
\end{tabular} & \begin{tabular}{|l|l|} 
Complete \\
\end{tabular} & $\begin{array}{l}\text { Thermally } \\
\text { Altered }\end{array}$ & na & na & na & na & na \\
\hline 81.2 & 79 & 8 & & 4 & & $40-50$ & & 55 & 57 & 1 & & Prehistoric & Metaquartzite & Unknown & Debitage & $\begin{array}{l}\text { Secondary } \\
\text { Flake }\end{array}$ & Proximal Fragment & \begin{tabular}{|l|} 
Thermally \\
Altered
\end{tabular} & na & na & na & na & na \\
\hline 81.3 & 79 & 8 & & 4 & & $40-50$ & & 55 & 57 & 1 & & Prehistoric & Metaquartzite & Unknown & Debitage & Tertiary Flake & Proximal Fragment & na & na & na & na & na & na \\
\hline 81.4 & 79 & 8 & & 4 & & $40-50$ & & 55 & 57 & 1 & & Prehistoric & Metaquartzite & Unknown & Debitage & Tertiary Flake & Proximal Fragment & $\begin{array}{l}\text { Thermally } \\
\text { Altered }\end{array}$ & na & na & na & na & na \\
\hline 81.5 & 79 & 8 & & 4 & & $\begin{array}{ll}40-50 \\
\end{array}$ & & 55 & 57 & 1 & & Prehistoric & Orthoquartzite & Unknown & Debitage & Tertiary Flake & Distal Fragment & na & na & na & na & na & na \\
\hline 81.6 & 79 & 8 & & 4 & & $40-50$ & & 55 & 57 & 1 & & Prehistoric & Silicified Wood & Unknown & Debitage & Tertiary Flake & Complete & na & na & na & na & na & na \\
\hline 82 & 80 & 8 & & 4 & & $40-50$ & SE corner & 55 & 57 & 1 & & Prehistoric & Chert & Unknown & Core & \begin{tabular}{|l} 
Multi- \\
Directional
\end{tabular} & Fragment & na & $\begin{array}{l}7+\text { flakes removed, cortex } \\
\text { remaining }\end{array}$ & 20.76 & na & na & na \\
\hline 83.1 & 83 & 8 & & 5 & & $\begin{array}{l}50-60 \\
\end{array}$ & & 55 & 57 & 1 & & Prehistoric & Chert & Unknown & Debitage & Tertiary Flake & Complete & na & na & na & na & na & na \\
\hline 83.2 & 83 & 8 & & 5 & & $50-60$ & & 55 & 57 & 1 & & Prehistoric & Metaquartzite & Unknown & Debitage & \begin{tabular}{|l|}
$\begin{array}{l}\text { Secondary } \\
\text { Flake }\end{array}$ \\
\end{tabular} & Proximal Fragment & $\begin{array}{l}\text { Thermally } \\
\text { Altered }\end{array}$ & na & na & na & na & na \\
\hline 83.3 & 83 & 8 & & 5 & & $50-60$ & & 55 & 57 & 1 & & Prehistoric & Metaquartzite & Unknown & Debitage & $\begin{array}{l}\text { Secondary } \\
\text { Flake }\end{array}$ & Complete & \begin{tabular}{|l} 
Thermally \\
Altered
\end{tabular} & na & na & na & na & na \\
\hline 83.4 & 83 & 8 & & 5 & & $50-60$ & & 55 & 57 & 1 & & Prehistoric & Orthoquartzite & Unknown & Debitage & Tertiary Flake & Medial Fragment & na & na & na & na & na & na \\
\hline
\end{tabular}




\begin{tabular}{|c|c|c|c|c|c|c|c|c|c|c|c|c|c|c|c|c|c|c|c|c|c|c|c|}
\hline Lot No. & FS No. & $\begin{array}{l}\text { Unit } \\
\text { No. }\end{array}$ & $\begin{array}{c}\text { ST } \\
\text { No. }\end{array}$ & Level & $\begin{array}{l}\text { Depth } \\
\text { (cmbs) }\end{array}$ & $\begin{array}{c}\text { Depth } \\
\text { (cmbd) }\end{array}$ & Provience & Northing & Easting & $\begin{array}{c}\text { No. of } \\
\text { Specimens }\end{array}$ & $\begin{array}{l}\text { Time } \\
\text { Period }\end{array}$ & Era/ Phase & Artifact Material & Use Context & $\begin{array}{c}\text { Artifact } \\
\text { Description }\end{array}$ & $\begin{array}{c}\text { Artifact Sub- } \\
\text { description }\end{array}$ & $\begin{array}{c}\text { Artifact } \\
\text { Form/Condition }\end{array}$ & \begin{tabular}{|c|} 
Surface \\
Treatment
\end{tabular} & Comments & $\begin{array}{l}\text { Weight in } \\
\text { grams }\end{array}$ & $\begin{array}{l}\text { Length in } \\
\mathrm{mm}\end{array}$ & $\begin{array}{l}\text { Width in } \\
\mathrm{mm}\end{array}$ & \begin{tabular}{|c|} 
Thickness in \\
$\mathrm{mm}$
\end{tabular} \\
\hline 83.5 & 83 & 8 & & 5 & & $50-60$ & & 55 & 57 & 2 & & Prehistoric & Silicified Wood & Unknown & \begin{tabular}{|l|} 
Debitage \\
\end{tabular} & Tertiary Flake & Distal Fragment & na & na & na & na & na & na \\
\hline 83.6 & 83 & 8 & & 5 & & $50-60$ & & 55 & 57 & 1 & & Prehistoric & Silicified Wood & Unknown & Debitage & Tertiary Flake & Proximal Fragment & na & na & na & na & na & na \\
\hline 84.1 & 106 & 8 & & 6 & & 60-70 & & 55 & 57 & 1 & & Prehistoric & Chert & Unknown & Debitage & \begin{tabular}{|l|} 
Tertiary Flake \\
\end{tabular} & Medial Fragment & na & na & na & na & na & na \\
\hline 84.2 & 106 & 8 & & 6 & & $\begin{array}{ll}60-70 \\
\end{array}$ & & 55 & 57 & 1 & & Prehistoric & Chert & Unknown & Debitage & Tertiary Flake & Proximal Fragment & \begin{tabular}{|l|} 
Thermally \\
Altered
\end{tabular} & na & na & na & na & na \\
\hline 84.3 & 106 & 8 & & 6 & & \begin{tabular}{ll|}
$60-70$ \\
\end{tabular} & & 55 & 57 & 1 & & Prehistoric & Metaquartzite & Unknown & Debitage & Tertiary Flake & Proximal Fragment & $\begin{array}{l}\text { Thermally } \\
\text { Altered }\end{array}$ & na & na & na & na & na \\
\hline 85.1 & 72 & 9 & & 1 & & $8-20$ & & 54 & 56 & 1 & & Prehistoric & Chert & Unknown & Debitage & \begin{tabular}{|l|}
$\begin{array}{l}\text { Secondary } \\
\text { Flake }\end{array}$ \\
\end{tabular} & Medial Fragment & na & na & na & na & na & na \\
\hline 85.2 & 72 & 9 & & 1 & & \begin{tabular}{|l|}
$8-20$ \\
\end{tabular} & & 54 & 56 & 1 & & Prehistoric & Novaculite & Unknown & Debitage & Tertiary Flake & Distal Fragment & na & na & na & na & na & na \\
\hline 85.3 & 72 & 9 & & 1 & & $8-20$ & & 54 & 56 & 1 & & Prehistoric & Metaquartzite & Unknown & Debitage & \begin{tabular}{|l|} 
Primary Flake \\
\end{tabular} & Proximal Fragment & $\begin{array}{l}\text { Thermally } \\
\text { Altered }\end{array}$ & na & na & na & na & na \\
\hline 85.4 & 72 & 9 & & 1 & & $8-20$ & & 54 & 56 & 1 & & Prehistoric & Metaquartzite & Unknown & Debitage & Tertiary Flake & Medial Fragment & $\begin{array}{l}\text { Thermally } \\
\text { Altered }\end{array}$ & na & na & na & na & na \\
\hline 86.1 & 77 & 9 & & 2 & & $20-30$ & & 54 & 56 & 1 & & Prehistoric & Chert & Unknown & Debitage & \begin{tabular}{|l|}
$\begin{array}{l}\text { Secondary } \\
\text { Flake }\end{array}$ \\
\end{tabular} & Proximal Fragment & $\begin{array}{l}\text { Thermally } \\
\text { Altered }\end{array}$ & na & na & na & na & na \\
\hline 86.10 & 77 & 9 & & 2 & & $20-30$ & & 54 & 56 & 1 & & Prehistoric & Silicified Wood & |Unknown & Debitage & Tertiary Flake & Proximal Fragment & na & na & na & na & na & na \\
\hline 86.11 & 77 & 9 & & 2 & & $20-30$ & & 54 & 56 & 1 & & Prehistoric & chert & Unknown & Debitage & Tertiary Flake & Medial Fragment & na & na & na & na & na & na \\
\hline 86.12 & 77 & 9 & & 2 & & $20-30$ & & 54 & 56 & 2 & & Prehistoric & Silicified Wood & Unknown & Debitage & Tertiary Flake & Medial Fragment & na & na & na & na & na & na \\
\hline 86.2 & 77 & 9 & & 2 & & $20-30$ & & 54 & 56 & 1 & & Prehistoric & Chert & Unknown & Debitage & Chip & Decorticated & $\begin{array}{l}\text { Thermally } \\
\text { Altered }\end{array}$ & na & na & na & na & na \\
\hline 86.3 & 77 & 9 & & 2 & & $20-30$ & & 54 & 56 & 1 & & Prehistoric & Chert & Unknown & Debitage & Tertiary Flake & Complete & na & na & na & na & na & na \\
\hline 86.4 & 77 & 9 & & 2 & & $20-30$ & & 54 & 56 & 1 & & Prehistoric & Chert & Unknown & Debitage & Tertiary Flake & Medial Fragment & $\begin{array}{l}\text { Thermally } \\
\text { Altered }\end{array}$ & na & na & na & na & na \\
\hline 86.5 & 77 & 9 & & 2 & & $20-30$ & & 54 & 56 & 1 & & Prehistoric & Metaquartzite & Unknown & Debitage & $\begin{array}{l}\text { Secondary } \\
\text { Flake }\end{array}$ & Medial Fragment & $\begin{array}{l}\text { Thermally } \\
\text { Altered }\end{array}$ & na & na & na & na & na \\
\hline 86.6 & 77 & 9 & & 2 & & 20-30 & & 54 & 56 & 2 & & Prehistoric & Metaquartzite & Unknown & Debitage & \begin{tabular}{|l|}
$\begin{array}{l}\text { Secondary } \\
\text { Flake }\end{array}$ \\
\end{tabular} & Proximal Fragment & $\begin{array}{l}\text { Thermally } \\
\text { Altered }\end{array}$ & na & na & na & na & na \\
\hline 86.7 & 77 & 9 & & 2 & & 20-30 & & 54 & 56 & 1 & & Prehistoric & Metaquartzite & Unknown & Debitage & Tertiary Flake & Distal Fragment & $\begin{array}{l}\text { Thermally } \\
\text { Altered }\end{array}$ & na & na & na & na & na \\
\hline 86.8 & 77 & 9 & & 2 & & $20-30$ & & 54 & 56 & 1 & & Prehistoric & Silicified Wood & Unknown & Debitage & Tertiary Flake & Distal Fragment & \begin{tabular}{|l|} 
Thermally \\
Altered
\end{tabular} & na & na & na & na & na \\
\hline 86.9 & 77 & 9 & & 2 & & 20-30 & & 54 & 56 & 1 & & Prehistoric & Silicified Wood & Unknown & Debitage & $\begin{array}{l}\text { Secondary } \\
\text { Flake }\end{array}$ & Complete & na & na & na & na & na & na \\
\hline 87.1 & 78 & 9 & & 3 & & $30-40$ & & 54 & 56 & 1 & & Prehistoric & Chert & Unknown & Debitage & \begin{tabular}{|l|} 
Secondary \\
Flake
\end{tabular} & Proximal Fragment & \begin{tabular}{|l|} 
Thermally \\
Altered
\end{tabular} & na & na & na & na & na \\
\hline 87.2 & 78 & 9 & & 3 & & $30-40$ & & 54 & 56 & 1 & & Prehistoric & Metaquartzite & Unknown & Debitage & Tertiary Flake & Proximal Fragment & \begin{tabular}{|l|} 
Thermally \\
Altered
\end{tabular} & na & na & na & na & na \\
\hline 87.3 & 78 & 9 & & 3 & & $30-40$ & & 54 & 56 & 1 & & Prehistoric & Silicified Wood & Unknown & Debitage & \begin{tabular}{|l} 
Secondary \\
Flake
\end{tabular} & Proximal Fragment & \begin{tabular}{|l|} 
Thermally \\
Altered
\end{tabular} & na & na & na & na & na \\
\hline 87.4 & 78 & 9 & & 3 & & $30-40$ & & 54 & 56 & 1 & & Prehistoric & Silicified Wood & Unknown & Debitage & Tertiary Flake & Medial Fragment & na & na & na & na & na & na \\
\hline 87.5 & 78 & 9 & & 3 & & $30-40$ & & 54 & 56 & 1 & & Prehistoric & Silicified Wood & Unknown & Debitage & Tertiary Flake & Proximal Fragment & na & na & na & na & na & na \\
\hline 88.1 & 81 & 9 & & 4 & & 40-50 & & 54 & 56 & 1 & & Prehistoric & Metaquartzite & Unknown & Debitage & $\begin{array}{l}\text { Secondary } \\
\text { Flake }\end{array}$ & Proximal Fragment & na & na & na & na & na & na \\
\hline
\end{tabular}




\begin{tabular}{|c|c|c|c|c|c|c|c|c|c|c|c|c|c|c|c|c|c|c|c|c|c|c|c|}
\hline Lot No. & FS No. & $\begin{array}{l}\text { Unit } \\
\text { No. }\end{array}$ & $\begin{array}{l}\text { ST } \\
\text { No. }\end{array}$ & Level & $\begin{array}{l}\text { Depth } \\
\text { (cmbs) }\end{array}$ & $\begin{array}{l}\text { Depth } \\
\text { (cmbd) }\end{array}$ & Provience & Northing & Easting & $\begin{array}{c}\text { No. of } \\
\text { Specimens }\end{array}$ & $\begin{array}{c}\text { Time } \\
\text { Period }\end{array}$ & Era/Phase & Artifact Material & Use Context & $\begin{array}{c}\text { Artifact } \\
\text { Description }\end{array}$ & $\begin{array}{l}\text { Artifact Sub- } \\
\text { description }\end{array}$ & $\begin{array}{c}\text { Artifact } \\
\text { Form/Condition }\end{array}$ & $\begin{array}{c}\text { Surface } \\
\text { Treatment }\end{array}$ & Comments & $\begin{array}{c}\text { Weight in } \\
\text { grams }\end{array}$ & $\begin{array}{c}\text { Length in } \\
\mathrm{mm}\end{array}$ & $\begin{array}{c}\text { Width in } \\
\mathrm{mm}\end{array}$ & $\begin{array}{c}\text { Thickness in } \\
\mathrm{mm}\end{array}$ \\
\hline 88.2 & 81 & 9 & & 4 & & $40-50$ & & 54 & 56 & 1 & & Prehistoric & Metaquartzite & Unknown & Debitage & Tertiary Flake & \begin{tabular}{|l|l|} 
Complete \\
\end{tabular} & $\begin{array}{l}\text { Thermally } \\
\text { Altered }\end{array}$ & na & na & na & na & na \\
\hline 88.3 & 81 & 9 & & 4 & & $40-50$ & & 54 & 56 & 1 & & Prehistoric & \begin{tabular}{|l|} 
Silicified Wood \\
\end{tabular} & Unknown & Debitage & $\begin{array}{l}\text { Secondary } \\
\text { Flake }\end{array}$ & Proximal Fragment & na & na & na & na & na & na \\
\hline 88.4 & 81 & 9 & & 4 & & $40-50$ & & 54 & 56 & 1 & & Prehistoric & Silicified Wood & Unknown & Debitage & $\begin{array}{l}\text { Secondary } \\
\text { Flake }\end{array}$ & Distal Fragment & na & na & na & na & na & na \\
\hline 89 & 84 & 9 & & 5 & & $50-60$ & & 54 & 56 & 1 & & Prehistoric & Chert & Unknown & Debitage & Tertiary Flake & Distal Fragment & \begin{tabular}{|l} 
Thermally \\
Altered
\end{tabular} & na & na & na & na & na \\
\hline 90.1 & 107 & 9 & & 6 & & $260-70$ & & 54 & 56 & 1 & & Prehistoric & Chert & Unknown & Debitage & Tertiary Flake & Complete & na & na & na & na & na & na \\
\hline 90.2 & 107 & 9 & & 6 & & $60-70$ & & 54 & 56 & 1 & & Prehistoric & Metaquartzite & Unknown & Debitage & $\begin{array}{l}\text { Secondary } \\
\text { Flake }\end{array}$ & Distal Fragment & na & na & na & na & na & na \\
\hline 90.3 & 107 & 9 & & 6 & & $60-70$ & & 54 & 56 & 1 & & Prehistoric & Silicified Wood & Unknown & Debitage & Tertiary Flake & Distal Fragment & \begin{tabular}{|l|}
$\begin{array}{l}\text { Thermally } \\
\text { Altered }\end{array}$ \\
\end{tabular} & na & na & na & na & na \\
\hline $\begin{array}{ll}90.4 \\
\end{array}$ & 107 & 9 & & 6 & & $60-70$ & & 54 & 56 & 1 & & Prehistoric & Silicified Wood & Unknown & Debitage & Tertiary Flake & Proximal Fragment & na & na & $\mathrm{na}$ & na & na & 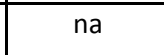 \\
\hline 91.1 & 115 & 1 & & 8 & & $79-90$ & & 77 & 51 & 1 & & Prehistoric & Chert & Unknown & Debitage & Primary Flake & Proximal Fragment & na & na & na & na & na & na \\
\hline 91.10 & 115 & 1 & & 8 & & $79-90$ & & 77 & 51 & 1 & & Prehistoric & Silicified Wood & Unknown & Debitage & $\begin{array}{l}\text { Secondary } \\
\text { Flake }\end{array}$ & Medial Fragment & na & na & na & na & na & na \\
\hline 91.11 & 115 & 1 & & 8 & & $79-90$ & & 77 & 51 & 1 & & Prehistoric & Silicified Wood & Unknown & Debitage & Tertiary Flake & Proximal Fragment & na & na & na & na & na & $\mathrm{na}$ \\
\hline 91.12 & 115 & 1 & & 8 & & 79-90 & & 77 & 51 & 1 & & Prehistoric & Silicified Wood & Unknown & Debitage & Tertiary Flake & Distal Fragment & na & na & na & na & na & $\mathrm{na}$ \\
\hline 91.2 & 115 & 1 & & 8 & & $79-90$ & & 77 & 51 & 1 & & Prehistoric & Chert & Unknown & Debitage & $\begin{array}{l}\text { Secondary } \\
\text { Flake }\end{array}$ & Proximal Fragment & na & na & na & na & na & na \\
\hline 91.3 & 115 & 1 & & 8 & & $79-90$ & & 77 & 51 & 1 & & Prehistoric & Chert & Unknown & Debitage & $\begin{array}{l}\text { Secondary } \\
\text { Flake }\end{array}$ & Medial Fragment & na & na & na & na & na & na \\
\hline 91.4 & 115 & 1 & & 8 & & 79-90 & & 77 & 51 & 1 & & Prehistoric & Chert & Unknown & Debitage & Tertiary Flake & Medial Fragment & na & na & na & na & na & na \\
\hline 91.5 & 115 & 1 & & 8 & & 79-90 & & 77 & 51 & 1 & & Prehistoric & Chert & Unknown & Debitage & Tertiary Flake & Medial Fragment & na & na & na & na & na & na \\
\hline 91.6 & 115 & 1 & & 8 & & $79-90$ & & 77 & 51 & 1 & & Prehistoric & Metaquartzite & Unknown & Debitage & Tertiary Flake & Complete & na & na & na & na & na & $\mathrm{na}$ \\
\hline 91.7 & 115 & 1 & & 8 & & $79-90$ & & 77 & 51 & 1 & & Prehistoric & Metaquartzite & Unknown & Debitage & Tertiary Flake & Proximal Fragment & \begin{tabular}{|l|} 
Thermally \\
Altered
\end{tabular} & na & na & na & na & na \\
\hline 91.8 & 115 & 1 & & 8 & & $79-90$ & & 77 & 51 & 1 & & Prehistoric & Metaquartzite & Unknown & Debitage & Tertiary Flake & Proximal Fragment & na & na & na & na & na & na \\
\hline 91.9 & 115 & 1 & & 8 & & 79-90 & & 77 & 51 & 1 & & Prehistoric & Metaquartzite & Unknown & Debitage & Tertiary Flake & Proximal Fragment & na & na & na & na & na & na \\
\hline 92.1 & 117 & 1 & & 9 & & $90-100$ & & 77 & 50 & 1 & Middle tc & Prehistoric & Chert & Unknown & \begin{tabular}{|l|} 
Dart Point \\
\end{tabular} & Gary & Complete & na & \begin{tabular}{|l|} 
Reworked Gary Dart Point; small, \\
triangular shaped body, straight \\
lateral edges, small but distinct \\
shoulders, contracting stem, \\
convex basal edge, no evidence of \\
utilization
\end{tabular} & 1.71 & 24.23 & 14.93 & 6.41 \\
\hline 92.2 & 117 & 1 & & 9 & & $90-100$ & & 77 & 50 & 1 & & Prehistoric & Metaquartzite & Unknown & Debitage & $\begin{array}{l}\text { Secondary } \\
\text { Flake }\end{array}$ & Complete & na & na & na & na & na & na \\
\hline 92.3 & 117 & 1 & & 9 & & $90-100$ & & 77 & 50 & 1 & & Prehistoric & Metaquartzite & Unknown & Debitage & $\begin{array}{l}\text { Secondary } \\
\text { Flake }\end{array}$ & Proximal Fragment & na & na & na & na & na & na \\
\hline $\begin{array}{ll}92.4 \\
\end{array}$ & 117 & 1 & & 9 & & 90-100 & & 77 & 50 & 1 & & Prehistoric & Metaquartzite & Unknown & Debitage & Tertiary Flake & Medial Fragment & na & na & na & na & na & na \\
\hline 92.5 & 117 & 1 & & 9 & & $90-100$ & & 77 & 50 & 1 & & Prehistoric & Silicified Wood & Unknown & Debitage & $\begin{array}{l}\text { Secondary } \\
\text { Flake }\end{array}$ & Medial Fragment & na & na & na & na & na & na \\
\hline
\end{tabular}




\begin{tabular}{|c|c|c|c|c|c|c|c|c|c|c|c|c|c|c|c|c|c|c|c|c|c|c|c|}
\hline Lot No. & FS No. & $\begin{array}{l}\text { Unit } \\
\text { No. }\end{array}$ & $\begin{array}{l}\text { ST } \\
\text { No. }\end{array}$ & Level & $\begin{array}{l}\text { Depth } \\
\text { (cmbs) }\end{array}$ & \begin{tabular}{|l|} 
Depth \\
(cmbd)
\end{tabular} & Provience & Northing & Easting & \begin{tabular}{|c|}
$\begin{array}{c}\text { No. of } \\
\text { specimens }\end{array}$ \\
\end{tabular} & $\begin{array}{l}\text { Time } \\
\text { Period }\end{array}$ & Era/Phase & Artifact Material & Use Context & $\begin{array}{c}\text { Artifact } \\
\text { Description }\end{array}$ & $\begin{array}{c}\text { Artifact Sub- } \\
\text { description }\end{array}$ & $\begin{array}{c}\text { Artifact } \\
\text { Form/Condition }\end{array}$ & \begin{tabular}{|c} 
Surface \\
Treatment
\end{tabular} & Comments & $\begin{array}{l}\text { Weight in } \\
\text { grams }\end{array}$ & $\begin{array}{l}\text { Length in } \\
\mathrm{mm}\end{array}$ & $\begin{array}{c}\text { Width in } \\
\mathrm{mm}\end{array}$ & \begin{tabular}{|c|} 
Thickness in \\
$\mathrm{mm}$
\end{tabular} \\
\hline 92.6 & 117 & 1 & & 9 & & 90-100 & & 77 & 50 & 1 & & Prehistoric & Silicified Wood & Unknown & \begin{tabular}{|l|} 
Debitage \\
\end{tabular} & Tertiary Flake & Proximal Fragment & na & na & na & na & na & na \\
\hline 93 & 119 & 1 & & 10 & & $100-110$ & & 77 & 51 & 1 & & Prehistoric & Chert & Unknown & Debitage & Tertiary Flake & Complete & na & na & na & na & na & na \\
\hline 94.1 & 116 & 2 & & 8 & & \begin{tabular}{|l|}
$80-90$ \\
\end{tabular} & & 77 & 49 & 1 & & Prehistoric & Metaquartzite & Unknown & Debitage & \begin{tabular}{|l|}
$\begin{array}{l}\text { Secondary } \\
\text { Flake }\end{array}$ \\
\end{tabular} & Complete & $\begin{array}{l}\text { Thermally } \\
\text { Altered }\end{array}$ & & na & na & na & na \\
\hline 94.10 & 116 & 2 & & 8 & & \begin{tabular}{|l|}
$80-90$ \\
\end{tabular} & & 77 & 49 & 1 & & Prehistoric & Metaquartzite & Unknown & Debitage & \begin{tabular}{|l|} 
Secondary \\
Flake
\end{tabular} & Distal Fragment & na & na & na & na & na & na \\
\hline 94.2 & 116 & 2 & & 8 & & \begin{tabular}{|l|}
$80-90$ \\
\end{tabular} & & 77 & 49 & 1 & & Prehistoric & Metaquartzite & Unknown & Debitage & Primary Flake & Complete & \begin{tabular}{|l|} 
Thermally \\
Altered
\end{tabular} & na & na & na & na & na \\
\hline 94.3 & 116 & 2 & & 8 & & \begin{tabular}{|l|}
$80-90$ \\
\end{tabular} & & 77 & 49 & 1 & & Prehistoric & Metaquartzite & Unknown & Debitage & Primary Flake & Distal Fragment & na & na & na & na & na & na \\
\hline 94.4 & 116 & 2 & & 8 & & \begin{tabular}{|l|}
$80-90$ \\
\end{tabular} & & 77 & 49 & 1 & & Prehistoric & Metaquartzite & Unknown & Debitage & \begin{tabular}{|l|} 
Secondary \\
Flake
\end{tabular} & Medial Fragment & $\begin{array}{l}\text { Thermally } \\
\text { Altered }\end{array}$ & na & na & na & na & na \\
\hline 94.5 & 116 & 2 & & 8 & & \begin{tabular}{|l|}
$80-90$ \\
\end{tabular} & & 77 & 49 & 1 & & Prehistoric & Metaquartzite & Unknown & Debitage & Tertiary Flake & Proximal Fragment & na & na & na & na & na & na \\
\hline 94.6 & 116 & 2 & & 8 & & \begin{tabular}{|l|}
$80-90$ \\
\end{tabular} & & 77 & 49 & 1 & & Prehistoric & Metaquartzite & Unknown & Debitage & Tertiary Flake & Distal Fragment & na & na & na & na & na & na \\
\hline 94.7 & 116 & 2 & & 8 & & \begin{tabular}{|l|}
$80-90$ \\
\end{tabular} & & 77 & 49 & 1 & & Prehistoric & Silicified Wood & Unknown & Debitage & $\begin{array}{l}\text { Secondary } \\
\text { Flake }\end{array}$ & Proximal Fragment & $\begin{array}{l}\text { Thermally } \\
\text { Altered }\end{array}$ & na & na & na & na & na \\
\hline $\begin{array}{ll}94.8 \\
\end{array}$ & 116 & 2 & & 8 & & \begin{tabular}{|l|}
$80-90$ \\
\end{tabular} & & 77 & 49 & 1 & & Prehistoric & Silicified Wood & Unknown & Debitage & \begin{tabular}{|l|} 
Secondary \\
Flake
\end{tabular} & Complete & $\begin{array}{l}\text { Thermally } \\
\text { Altered }\end{array}$ & na & na & na & na & na \\
\hline 94.9 & 116 & 2 & & 8 & & \begin{tabular}{|l|}
$80-90$ \\
\end{tabular} & & 77 & 49 & 1 & & Prehistoric & Metaquartzite & Unknown & Debitage & \begin{tabular}{|l|}
$\begin{array}{l}\text { Secondary } \\
\text { Flake }\end{array}$ \\
\end{tabular} & Medial Fragment & na & na & na & na & na & na \\
\hline 95.1 & 118 & 2 & & 9 & & |90-100 & & 77 & 49 & 1 & & Prehistoric & Metaquartzite & Unknown & Debitage & Tertiary Flake & Distal Fragment & \begin{tabular}{|l} 
Thermally \\
Altered
\end{tabular} & na & na & na & na & na \\
\hline 95.2 & 118 & 2 & & 9 & & |90-100 & & 77 & 49 & 1 & & Prehistoric & Metaquartzite & Unknown & Debitage & Tertiary Flake & Distal Fragment & \begin{tabular}{|l} 
Thermally \\
Altered
\end{tabular} & na & na & na & na & na \\
\hline 95.3 & 118 & 2 & & 9 & & |90-100 & & 77 & 49 & 1 & & Prehistoric & Metaquartzite & Unknown & Debitage & Tertiary Flake & Proximal Fragment & na & na & na & na & na & na \\
\hline 95.4 & 118 & 2 & & 9 & & |90-100 & & 77 & 49 & 1 & & Prehistoric & Silicified Wood & Unknown & Debitage & \begin{tabular}{|l|} 
Secondary \\
Flake
\end{tabular} & Distal Fragment & na & na & na & na & na & na \\
\hline 95.5 & 118 & 2 & & 9 & & |90-100 & & 77 & 49 & 1 & & Prehistoric & Metaquartzite & Unknown & Debitage & Tertiary Flake & Distal Fragment & na & na & na & na & na & na \\
\hline 96.1 & 120 & 2 & & 10 & & 100-110 & & 77 & 49 & 1 & & Prehistoric & Chert & Unknown & Debitage & \begin{tabular}{|l|} 
Secondary \\
Flake
\end{tabular} & Medial Fragment & na & na & na & na & na & na \\
\hline 96.2 & 120 & 2 & & 10 & & $100-110$ & & 77 & 49 & 1 & & Prehistoric & Metaquartzite & Unknown & Debitage & Tertiary Flake & Proximal Fragment & na & na & na & na & na & na \\
\hline 97.1 & 128 & 3 & & 8 & & \begin{tabular}{|l|}
$80-90$ \\
\end{tabular} & & 76 & 50 & 1 & & Prehistoric & Chert & Unknown & Debitage & \begin{tabular}{|l|}
$\begin{array}{l}\text { Secondary } \\
\text { Flake }\end{array}$ \\
\end{tabular} & Proximal Fragment & na & na & na & na & na & na \\
\hline 97.10 & 128 & 3 & & 8 & & \begin{tabular}{|l|}
$80-90$ \\
\end{tabular} & & 76 & 50 & 1 & & Prehistoric & Metaquartzite & Unknown & \begin{tabular}{|l|l|} 
Debitage \\
\end{tabular} & Tertiary Flake & Distal Fragment & na & na & na & na & na & na \\
\hline 97.11 & 128 & 3 & & 8 & & \begin{tabular}{|l|}
$80-90$ \\
\end{tabular} & & 76 & 50 & 1 & & Prehistoric & Metaquartzite & Unknown & Debitage & Tertiary Flake & Distal Fragment & na & na & na & na & na & na \\
\hline 97.2 & 128 & 3 & & 8 & & \begin{tabular}{|l|}
$80-90$ \\
\end{tabular} & & 76 & 50 & 1 & & Prehistoric & Chert & Unknown & Debitage & \begin{tabular}{|l|} 
Tertiary Flake \\
\end{tabular} & \begin{tabular}{|l|} 
Distal Fragment \\
\end{tabular} & na & na & na & na & na & na \\
\hline 97.3 & 128 & 3 & & 8 & & \begin{tabular}{|l|}
$80-90$ \\
\end{tabular} & & 76 & 50 & 1 & & Prehistoric & Chert & Unknown & Debitage & \begin{tabular}{|l|} 
Tertiary Flake \\
\end{tabular} & Distal Fragment & na & na & na & na & na & na \\
\hline 97.4 & 128 & 3 & & 8 & & \begin{tabular}{|l|}
$80-90$ \\
\end{tabular} & & 76 & 50 & 1 & & Prehistoric & Metaquartzite & Unknown & Debitage & \begin{tabular}{|l|} 
Tertiary Flake \\
\end{tabular} & Medial Fragment & $\begin{array}{l}\text { Thermally } \\
\text { Altered }\end{array}$ & na & na & na & na & na \\
\hline 97.5 & 128 & 3 & & 8 & & \begin{tabular}{|l|}
$80-90$ \\
\end{tabular} & & 76 & 50 & 1 & & Prehistoric & Metaquartzite & Unknown & Debitage & Tertiary Flake & Complete & \begin{tabular}{|l|} 
Thermally \\
Altered
\end{tabular} & na & na & na & na & na \\
\hline 97.6 & 128 & 3 & & 8 & & \begin{tabular}{|l|}
$80-90$ \\
\end{tabular} & & 76 & 50 & 1 & & Prehistoric & Silicified Wood & Unknown & Debitage & Primary Flake & Complete & na & na & na & na & na & na \\
\hline
\end{tabular}




\begin{tabular}{|c|c|c|c|c|c|c|c|c|c|c|c|c|c|c|c|c|c|c|c|c|c|c|c|}
\hline Lot No. & FS No. & $\begin{array}{l}\text { Unit } \\
\text { No. }\end{array}$ & $\begin{array}{l}\text { ST } \\
\text { No } \\
\end{array}$ & Level & $\begin{array}{l}\text { Depth } \\
\text { (cmbs) }\end{array}$ & $\begin{array}{l}\text { Depth } \\
\text { (cmbd) }\end{array}$ & Provience & Northing & Easting & $\begin{array}{c}\text { No. of } \\
\text { Specimens }\end{array}$ & $\begin{array}{l}\text { Time } \\
\text { Period }\end{array}$ & Era/ Phase & Artifact Material & Use Context & $\begin{array}{c}\text { Artifact } \\
\text { Description }\end{array}$ & $\begin{array}{l}\text { Artifact Sub- } \\
\text { description }\end{array}$ & $\begin{array}{c}\text { Artifact } \\
\text { Form/Condition }\end{array}$ & $\begin{array}{c}\text { Surface } \\
\text { Treatment }\end{array}$ & Comments & $\begin{array}{c}\text { Weight in } \\
\text { grams }\end{array}$ & $\begin{array}{c}\text { Length in } \\
\mathrm{mm}\end{array}$ & $\begin{array}{c}\text { Width in } \\
\mathrm{mm}\end{array}$ & $\begin{array}{c}\text { Thickness in } \\
\mathrm{mm}\end{array}$ \\
\hline 97.7 & 128 & 3 & & 8 & & $80-90$ & & 76 & 50 & 1 & & Prehistoric & Silicified Wood & Unknown & Debitage & Primary Flake & Proximal Fragment & na & na & na & na & na & na \\
\hline $\begin{array}{ll}97.8 \\
\end{array}$ & 128 & 3 & & 8 & & \begin{tabular}{|l|l|}
$80-90$ \\
\end{tabular} & & 76 & 50 & 1 & & Prehistoric & Silicified Wood & Unknown & Debitage & Tertiary Flake & Distal Fragment & na & na & na & na & na & na \\
\hline $\begin{array}{ll}97.9 \\
\end{array}$ & 128 & 3 & & 8 & & $80-90$ & & 76 & 50 & 1 & & Prehistoric & Silicified Wood & Unknown & Debitage & Tertiary Flake & Distal Fragment & na & na & na & na & na & na \\
\hline $\begin{array}{l}98.1 \\
\end{array}$ & 129 & 3 & & 8 & & 90-100 & & 76 & 50 & 1 & & Prehistoric & Chert & Unknown & \begin{tabular}{|l} 
Unifacially \\
Modified \\
Flake
\end{tabular} & Tertiary Flake & Proximal Fragment & na & \begin{tabular}{|l} 
Unifacially modified along 5.79 \\
mm of the straight lateral edge, \\
modified edge utilized for sawing
\end{tabular} & na & 25.38 & 14.99 & 2.04 \\
\hline 98.2 & 129 & 3 & & 8 & & 90-100 & & 76 & 50 & 1 & & Prehistoric & Metaquartzite & Unknown & Debitage & $\begin{array}{l}\text { Secondary } \\
\text { Flake }\end{array}$ & Medial Fragment & $\begin{array}{l}\text { Thermally } \\
\text { Altered }\end{array}$ & na & na & na & na & na \\
\hline 99.1 & 130 & 3 & & 10 & & $100-110$ & & 76 & 50 & 1 & & Prehistoric & Chert & Unknown & Debitage & $\begin{array}{l}\text { Secondary } \\
\text { Flake }\end{array}$ & Distal Fragment & na & na & na & na & na & na \\
\hline 99.2 & 130 & 3 & & 10 & & $100-110$ & & 76 & 50 & 1 & & Prehistoric & Chert & Unknown & Debitage & Tertiary Flake & Medial Fragment & na & na & na & na & na & na \\
\hline 99.3 & 130 & 3 & & 10 & & $100-110$ & & 76 & 50 & 1 & & Prehistoric & Chert & Unknown & Debitage & Tertiary Flake & Complete & na & na & na & na & na & na \\
\hline 100 & 131 & 3 & & 11 & & $110-120$ & & 76 & 50 & 1 & & Prehistoric & Chert & Unknown & Debitage & \begin{tabular}{|l|} 
Secondary \\
Flake
\end{tabular} & Medial Fragment & na & na & na & na & na & na \\
\hline 101.1 & 123 & 4 & & 8 & & $80-90$ & & 75 & 49 & 1 & & Prehistoric & Chert & Unknown & Debitage & Tertiary Flake & Complete & na & na & na & na & na & na \\
\hline 101.10 & 123 & 4 & & 8 & & $80-90$ & & 75 & 49 & 1 & & Prehistoric & Metaquartzite & Unknown & Debitage & Tertiary Flake & Distal Fragment & na & na & na & na & na & na \\
\hline 101.11 & 123 & 4 & & 8 & & $80-90$ & & 75 & 49 & 1 & & Prehistoric & Silicified Wood & Unknown & Debitage & Tertiary Flake & Proximal Fragment & na & na & na & na & na & na \\
\hline 101.12 & 123 & 4 & & 8 & & $80-90$ & & 75 & 49 & 1 & & Prehistoric & Silicified Wood & Unknown & Debitage & Tertiary Flake & Medial Fragment & na & na & na & na & na & na \\
\hline 101.13 & 123 & 4 & & 8 & & $80-90$ & & 75 & 49 & 1 & & Prehistoric & Silicified Wood & Unknown & Debitage & Tertiary Flake & Distal Fragment & $\begin{array}{l}\text { Thermally } \\
\text { Altered }\end{array}$ & na & na & na & na & na \\
\hline 101.14 & 123 & 4 & & 8 & & $80-90$ & & 75 & 49 & 1 & & Prehistoric & Metaquartzite & Unknown & Debitage & Tertiary Flake & Complete & na & na & na & na & na & na \\
\hline 101.15 & 123 & 4 & & 8 & & $80-90$ & & 75 & 49 & 1 & & Prehistoric & Metaquartzite & Unknown & Debitage & Tertiary Flake & Complete & na & na & na & na & na & na \\
\hline 101.2 & 123 & 4 & & 8 & & $80-90$ & & 75 & 49 & 1 & & Prehistoric & Chert & Unknown & Debitage & $\begin{array}{l}\text { Secondary } \\
\text { Flake }\end{array}$ & Proximal Fragment & $\begin{array}{l}\text { Thermally } \\
\text { Altered }\end{array}$ & na & na & na & na & na \\
\hline 101.3 & 123 & 4 & & 8 & & \begin{tabular}{|l|l|}
$80-90$ \\
\end{tabular} & & 75 & 49 & 1 & & Prehistoric & Chert & Unknown & Debitage & \begin{tabular}{|l} 
Secondary \\
Flake
\end{tabular} & Proximal Fragment & na & na & na & na & $\mathrm{na}$ & na \\
\hline 101.4 & 123 & 4 & & 8 & & $80-90$ & & 75 & 49 & 1 & & Prehistoric & Chert & Unknown & Debitage & $\begin{array}{l}\text { Secondary } \\
\text { Flake }\end{array}$ & Proximal Fragment & na & na & na & na & na & na \\
\hline 101.5 & 123 & 4 & & 8 & & $80-90$ & & 75 & 49 & 1 & & Prehistoric & Chert & Unknown & Debitage & Tertiary Flake & Medial Fragment & na & na & na & na & na & na \\
\hline 101.6 & 123 & 4 & & 8 & & $80-90$ & & 75 & 49 & 1 & & Prehistoric & Metaquartzite & Unknown & Debitage & Primary Flake & Proximal Fragment & $\begin{array}{l}\text { Thermally } \\
\text { Altered }\end{array}$ & na & na & na & na & na \\
\hline 101.7 & 123 & 4 & & 8 & & \begin{tabular}{|l|l|}
$80-90$ \\
\end{tabular} & & 75 & 49 & 1 & & Prehistoric & Metaquartzite & Unknown & Debitage & Primary Flake & Medial Fragment & na & na & na & na & na & na \\
\hline $\begin{array}{ll}101.8 \\
\end{array}$ & 123 & 4 & & 8 & & $80-90$ & & 75 & 49 & 1 & & Prehistoric & Metaquartzite & Unknown & Debitage & Tertiary Flake & Proximal Fragment & na & na & na & na & na & na \\
\hline 101.9 & 123 & 4 & & 8 & & $80-90$ & & 75 & 49 & 1 & & Prehistoric & Metaquartzite & Unknown & Debitage & Tertiary Flake & Medial Fragment & na & na & na & na & na & na \\
\hline 102.1 & 124 & 4 & & 9 & & 90-100 & & 75 & 49 & 1 & & Prehistoric & Metaquartzite & Unknown & Debitage & Tertiary Flake & Proximal Fragment & $\begin{array}{l}\text { Thermally } \\
\text { Altered }\end{array}$ & na & na & na & na & na \\
\hline 102.2 & 124 & 4 & & 9 & & $90-100$ & & 75 & 49 & 1 & & Prehistoric & Metaquartzite & Unknown & Debitage & Tertiary Flake & Distal Fragment & na & na & na & na & $\mathrm{na}$ & na \\
\hline
\end{tabular}




\begin{tabular}{|c|c|c|c|c|c|c|c|c|c|c|c|c|c|c|c|c|c|c|c|c|c|c|c|}
\hline Lot No. & FS No. & $\begin{array}{l}\text { Unit } \\
\text { No. }\end{array}$ & $\begin{array}{l}\text { ST } \\
\text { No. }\end{array}$ & | Level & $\begin{array}{l}\text { Depth } \\
\text { (cmbs) }\end{array}$ & \begin{tabular}{|l|}
$\begin{array}{c}\text { Depth } \\
\text { (cmbd) }\end{array}$ \\
\end{tabular} & Provience & Northing & Easting & $\mid$\begin{tabular}{c|} 
No. of \\
Specimens
\end{tabular} & $\begin{array}{c}\text { Time } \\
\text { Period }\end{array}$ & Era/ Phase & Artifact Material & Use Context & $\begin{array}{c}\text { Artifact } \\
\text { Description }\end{array}$ & $\begin{array}{c}\text { Artifact Sub- } \\
\text { description }\end{array}$ & $\begin{array}{c}\text { Artifact } \\
\text { Form/Condition }\end{array}$ & \begin{tabular}{|c|} 
Surface \\
Treatment
\end{tabular} & Comments & $\begin{array}{c}\text { Weight in } \\
\text { grams }\end{array}$ & $\begin{array}{l}\text { Length in } \\
\mathrm{mm}\end{array}$ & $\begin{array}{c}\text { Width in } \\
\mathrm{mm}\end{array}$ & $\begin{array}{c}\text { Thickness in } \\
\mathrm{mm}\end{array}$ \\
\hline 103 & 125 & 4 & & 11 & & $\mid 110-120$ & & 75 & 49 & 1 & & Prehistoric & Chert & Unknown & Utilized Flake & \begin{tabular}{|l|} 
Secondary \\
Flake
\end{tabular} & Complete & na & \begin{tabular}{|l|}
$\begin{array}{l}\text { Utilized along } 5.01 \mathrm{~mm} \text { of the } \\
\text { concave lateral edge for scraping } \\
\text { soft materials }\end{array}$ \\
\end{tabular} & na & 26.63 & 23.32 & 3.38 \\
\hline 104.1 & 126 & 5 & & 7 & & 80-90 & & 74 & 50 & 1 & Middle to & Prehistoric & Chert & Unknown & Dart Point & Kent & Complete & na & \begin{tabular}{|l} 
Reworked Kent Dart Point; small, \\
triangular shaped body, straight \\
lateral edges, weak shoulders, \\
contracting stem, convex basal \\
edge, ne evidence of utilization
\end{tabular} & na & 30.13 & 13.25 & 7.41 \\
\hline 104.2 & 126 & 5 & & 7 & & 80-90 & & 74 & 50 & 1 & & Prehistoric & Chert & Unknown & Debitage & Primary Flake & Complete & $\begin{array}{l}\text { Thermally } \\
\text { Altered }\end{array}$ & na & na & na & na & na \\
\hline 104.3 & 126 & 5 & & 7 & & 80-90 & & 74 & 50 & 1 & & Prehistoric & Chert & Unknown & Debitage & $\begin{array}{l}\text { Secondary } \\
\text { Flake }\end{array}$ & Medial Fragment & $\begin{array}{l}\text { Thermally } \\
\text { Altered }\end{array}$ & na & na & na & na & na \\
\hline 104.4 & 126 & 5 & & 7 & & 80-90 & & 74 & 50 & 1 & & Prehistoric & Metaquartzite & | Unknown & Debitage & Primary Flake & Proximal Fragment & na & na & na & na & na & na \\
\hline 104.5 & 126 & 5 & & 7 & & $80-90$ & & 74 & 50 & 1 & & Prehistoric & Metaquartzite & Unknown & Debitage & $\begin{array}{l}\text { Secondary } \\
\text { Flake }\end{array}$ & Complete & \begin{tabular}{|l} 
Thermally \\
Altered
\end{tabular} & na & na & na & na & na \\
\hline 104.6 & 126 & 5 & & 7 & & 80-90 & & 74 & 50 & 1 & & Prehistoric & Metaquartzite & |Unknown & Debitage & $\begin{array}{l}\text { Secondary } \\
\text { Flake }\end{array}$ & Proximal Fragment & $\begin{array}{l}\text { Thermally } \\
\text { Altered }\end{array}$ & na & na & na & na & na \\
\hline 104.7 & 126 & 5 & & 7 & & $80-90$ & & 74 & 50 & 1 & & Prehistoric & Silicified Wood & |Unknown & Debitage & $\begin{array}{l}\text { Secondary } \\
\text { Flake }\end{array}$ & Complete & $\begin{array}{l}\text { Thermally } \\
\text { Altered }\end{array}$ & na & na & na & na & na \\
\hline 104.8 & 126 & 5 & & 7 & & 80-90 & & 74 & 50 & 1 & & Prehistoric & Silicified Wood & Unknown & Debitage & Primary Flake & Complete & na & na & na & na & na & na \\
\hline 104.9 & 126 & 5 & & 7 & & $80-90$ & & 74 & 50 & 1 & & Prehistoric & Silicified Wood & |Unknown & Debitage & $\begin{array}{l}\text { Secondary } \\
\text { Flake }\end{array}$ & Distal Fragment & na & na & na & na & na & na \\
\hline 105.1 & 127 & 5 & & 8 & & |90-100 & & 74 & 50 & 1 & & Prehistoric & Chert & |Unknown & Debitage & $\begin{array}{l}\text { Secondary } \\
\text { Flake }\end{array}$ & Distal Fragment & na & na & na & na & na & na \\
\hline 105.2 & 127 & 5 & & 8 & & \begin{tabular}{|l|}
$90-100$ \\
\end{tabular} & & 74 & 50 & 1 & & Prehistoric & Metaquartzite & |Unknown & Debitage & $\begin{array}{l}\text { Secondary } \\
\text { Flake }\end{array}$ & Complete & $\begin{array}{l}\text { Thermally } \\
\text { Altered }\end{array}$ & na & na & na & na & na \\
\hline 105.3 & 127 & 5 & & 8 & & |90-100 & & 74 & 50 & 1 & & Prehistoric & Metaquartzite & |Unknown & Debitage & $\begin{array}{l}\text { Secondary } \\
\text { Flake }\end{array}$ & Proximal Fragment & na & na & na & na & na & na \\
\hline 105.4 & 127 & 5 & & 8 & & 90-100 & & 74 & 50 & 1 & & Prehistoric & Silicified Wood & |Unknown & Debitage & Primary Flake & Medial Fragment & na & na & na & na & na & na \\
\hline 105.5 & 127 & 5 & & 8 & & \begin{tabular}{|l|}
$90-100$ \\
\end{tabular} & & 74 & 50 & 1 & & Prehistoric & Silicified Wood & |Unknown & Debitage & $\begin{array}{l}\text { Secondary } \\
\text { Flake }\end{array}$ & Proximal Fragment & $\begin{array}{l}\text { Thermally } \\
\text { Altered }\end{array}$ & na & na & na & na & na \\
\hline 106.1 & 132 & 6 & & 8 & & \begin{tabular}{|l|}
$80-90$ \\
\end{tabular} & & 67 & 62.5 & 1 & & Prehistoric & Chert & |Unknown & Debitage & $\begin{array}{l}\text { Secondary } \\
\text { Flake }\end{array}$ & Medial Fragment & $\begin{array}{l}\text { Thermally } \\
\text { Altered }\end{array}$ & na & na & na & na & na \\
\hline 106.2 & 132 & 6 & & 8 & & $\mid 80-90$ & & 67 & 62.5 & 1 & & Prehistoric & Silicified Wood & |Unknown & Debitage & Primary Flake & Proximal Fragment & na & na & na & na & na & na \\
\hline 107.1 & 133 & 6 & & 10 & & $\mid 100-110$ & & 67 & 62.5 & 1 & & Prehistoric & Chert & |Unknown & Debitage & Tertiary Flake & Proximal Fragment & na & na & na & na & na & na \\
\hline 107.2 & 133 & 6 & & 10 & & $\mid 100-110$ & & 67 & 62.5 & 1 & & Prehistoric & Metaquartzite & |Unknown & Debitage & Tertiary Flake & Distal Fragment & na & na & na & na & na & na \\
\hline 107.3 & 133 & 6 & & 10 & & $|100-110|$ & & 67 & 62.5 & 1 & & Prehistoric & Silicified Wood & Unknown & Debitage & $\begin{array}{l}\text { Secondary } \\
\text { Flake }\end{array}$ & Proximal Fragment & na & na & na & na & na & na \\
\hline 108 & 134 & 6 & & 11 & & $\mid 110-120$ & & 67 & 62.5 & 1 & & Prehistoric & Chert & | Unknown & Debitage & Tertiary Flake & Proximal Fragment & na & na & na & na & na & na \\
\hline 109 & 135 & 6 & & 12 & & $\mid 120-130$ & & 67 & 62.5 & 1 & & Prehistoric & Chert & |Unknown & Debitage & Tertiary Flake & Complete & na & na & na & na & na & na \\
\hline 110.1 & 136 & 7 & & 7 & & \begin{tabular}{|l|}
$70-80$ \\
\end{tabular} & & 67 & 59 & 1 & & Prehistoric & Metaquartzite & Unknown & Debitage & Primary Flake & Proximal Fragment & $\begin{array}{l}\text { Thermally } \\
\text { Altered }\end{array}$ & na & na & na & na & na \\
\hline 110.2 & 136 & 7 & & 7 & & |70-80 & & 67 & 59 & 1 & & Prehistoric & Metaquartzite & |Unknown & Debitage & $\begin{array}{l}\text { Secondary } \\
\text { Flake }\end{array}$ & Distal Fragment & $\begin{array}{l}\text { Thermally } \\
\text { Altered }\end{array}$ & na & na & na & na & na \\
\hline 110.3 & 136 & 7 & & 7 & & |70-80 & & 67 & 59 & 1 & & Prehistoric & Silicified Wood & | Unknown & Debitage & Tertiary Flake & Medial Fragment & na & na & na & na & na & na \\
\hline
\end{tabular}




\begin{tabular}{|c|c|c|c|c|c|c|c|c|c|c|c|c|c|c|c|c|c|c|c|c|c|c|c|}
\hline Lot No. & FS No. & $\begin{array}{l}\text { Unit } \\
\text { No. }\end{array}$ & $\begin{array}{l}\text { ST } \\
\text { No. }\end{array}$ & Level & $\begin{array}{c}\text { Depth } \\
\text { (cmbs) }\end{array}$ & $\begin{array}{l}\text { Depth } \\
\text { (cmbd) }\end{array}$ & Provience & Northing & Easting & \begin{tabular}{|c|}
$\begin{array}{c}\text { No. of } \\
\text { Specimens }\end{array}$ \\
\end{tabular} & $\begin{array}{c}\text { Time } \\
\text { Period } \\
\end{array}$ & Era/Phase & Artifact Material & Use Context & $\begin{array}{c}\text { Artifact } \\
\text { Description }\end{array}$ & \begin{tabular}{|c|} 
Artifact Sub- \\
description \\
\end{tabular} & $\begin{array}{c}\text { Artifact } \\
\text { Form/Condition }\end{array}$ & $\begin{array}{c}\text { Surface } \\
\text { Treatment }\end{array}$ & Comments & $\begin{array}{c}\text { Weight in } \\
\text { grams }\end{array}$ & $\begin{array}{c}\text { Length in } \\
\mathrm{mm}\end{array}$ & $\begin{array}{c}\text { Width in } \\
\mathrm{mm}\end{array}$ & \begin{tabular}{|c|} 
Thickness in \\
$\mathrm{mm}$
\end{tabular} \\
\hline 110.4 & 136 & 7 & & 7 & & $70-80$ & & 67 & 59 & 1 & & Prehistoric & Metaquartzite & Unknown & Debitage & Primary Flake & Proximal Fragment & \begin{tabular}{|l} 
Thermally \\
Altered
\end{tabular} & na & na & na & na & na \\
\hline 111 & 137 & 7 & & 8 & & $80-90$ & & 67 & 59 & 1 & & Prehistoric & Chert & Unknown & Debitage & Tertiary Flake & Complete & na & na & na & na & na & na \\
\hline 112.1 & 108 & 8 & & 7 & & $70-80$ & & 55 & 57 & 1 & & Prehistoric & Chert & Unknown & Debitage & Tertiary Flake & Complete & na & na & na & na & na & na \\
\hline 112.2 & 108 & 8 & & 7 & & $70-80$ & & 55 & 57 & 1 & & Prehistoric & Metaquartzite & Unknown & Debitage & \begin{tabular}{|l|} 
Primary Flake \\
\end{tabular} & Proximal Fragment & $\begin{array}{l}\text { Thermally } \\
\text { Altered }\end{array}$ & na & na & na & na & na \\
\hline 112.3 & 108 & 8 & & 7 & & $\begin{array}{ll}70-80 \\
\end{array}$ & & 55 & 57 & 1 & & Prehistoric & Metaquartzite & Unknown & Debitage & Primary Flake & Medial Fragment & na & na & na & na & na & na \\
\hline 112.4 & 108 & 8 & & 7 & & $70-80$ & & 55 & 57 & 1 & & Prehistoric & Metaquartzite & Unknown & Debitage & \begin{tabular}{|l} 
Secondary \\
Flake
\end{tabular} & Proximal Fragment & na & na & na & na & na & na \\
\hline 112.5 & 108 & 8 & & 7 & & $70-80$ & & 55 & 57 & 1 & & Prehistoric & Silicified Wood & Unknown & Debitage & Primary Flake & Distal Fragment & na & na & na & na & na & na \\
\hline 112.6 & 108 & 8 & & 7 & & $70-80$ & & 55 & 57 & 1 & & Prehistoric & Silicified Wood & Unknown & Debitage & \begin{tabular}{|l|}
$\begin{array}{l}\text { Secondary } \\
\text { Flake }\end{array}$ \\
\end{tabular} & Proximal Fragment & na & na & na & na & na & na \\
\hline 112.7 & 108 & 8 & & 7 & & $70-80$ & & 55 & 57 & 1 & & Prehistoric & Silicified Wood & Unknown & Debitage & $\begin{array}{l}\text { Secondary } \\
\text { Flake }\end{array}$ & Medial Fragment & na & na & na & na & na & na \\
\hline 113.1 & 110 & 8 & & 8 & & $\begin{array}{ll}80-90 \\
\end{array}$ & & 55 & 57 & 1 & & Prehistoric & Chert & Unknown & Debitage & $\begin{array}{l}\text { Secondary } \\
\text { Flake }\end{array}$ & Proximal Fragment & na & na & na & na & na & na \\
\hline 113.2 & 110 & 8 & & 8 & & $\begin{array}{ll}80-90 \\
\end{array}$ & & 55 & 57 & 1 & & Prehistoric & Chert & Unknown & Debitage & \begin{tabular}{|l|}
$\begin{array}{l}\text { Secondary } \\
\text { Flake }\end{array}$ \\
\end{tabular} & Distal Fragment & na & na & na & na & na & na \\
\hline 113.3 & 110 & 8 & & 8 & & $\begin{array}{ll}80-90 \\
\end{array}$ & & 55 & 57 & 1 & & Prehistoric & Chert & Unknown & Debitage & Tertiary Flake & Distal Fragment & na & na & na & na & na & na \\
\hline 113.4 & 110 & 8 & & 8 & & $\begin{array}{ll}80-90 \\
\end{array}$ & & 55 & 57 & 2 & & Prehistoric & Metaquartzite & Unknown & Debitage & Tertiary Flake & Distal Fragment & na & na & na & na & na & na \\
\hline 114.1 & 113 & 8 & & 9 & & $90-100$ & & 55 & 57 & 2 & & Prehistoric & Chert & Unknown & Debitage & Tertiary Flake & Proximal Fragment & na & na & na & na & na & na \\
\hline 114.2 & 113 & 8 & & 9 & & $90-100$ & & 55 & 57 & 1 & & Prehistoric & Chert & Unknown & Debitage & Tertiary Flake & Proximal Fragment & $\begin{array}{l}\text { Thermally } \\
\text { Altered }\end{array}$ & na & na & na & na & na \\
\hline 114.3 & 113 & 8 & & 9 & & 90-100 & & 55 & 57 & 1 & & Prehistoric & Chert & Unknown & Debitage & Tertiary Flake & Medial Fragment & na & na & na & na & na & na \\
\hline 114.4 & 113 & 8 & & 9 & & $90-100$ & & 55 & 57 & 1 & & Prehistoric & Metaquartzite & Unknown & Debitage & \begin{tabular}{|l} 
Secondary \\
Flake
\end{tabular} & Medial Fragment & na & na & na & na & na & na \\
\hline 115 & $\begin{array}{ll}114 \\
\end{array}$ & 8 & & 10 & & 100-110 & & 55 & 57 & 1 & & Prehistoric & Chert & Unknown & Debitage & Tertiary Flake & Medial Fragment & na & na & na & na & na & na \\
\hline 116.1 & 121 & 8 & & 11 & & $110-120$ & & 55 & 57 & 1 & & Prehistoric & Chert & Unknown & Debitage & \begin{tabular}{|l|} 
Secondary \\
Flake
\end{tabular} & Proximal Fragment & na & na & na & na & na & na \\
\hline 116.2 & 121 & 8 & & 11 & & $110-120$ & & 55 & 57 & 3 & & Prehistoric & Chert & Unknown & Debitage & Tertiary Flake & Proximal Fragment & na & na & na & na & na & na \\
\hline 116.3 & 121 & 8 & & $\overline{11}$ & & $110-120$ & & 55 & 57 & 1 & & Prehistoric & Chert & Unknown & Debitage & Tertiary Flake & Medial Fragment & na & na & na & na & na & na \\
\hline 117.1 & 122 & 8 & & 12 & & $120-130$ & & 55 & 57 & 1 & & Prehistoric & Chert & Unknown & Debitage & $\begin{array}{l}\text { Secondary } \\
\text { Flake }\end{array}$ & Proximal Fragment & \begin{tabular}{|l|} 
Thermally \\
Altered
\end{tabular} & na & na & na & na & na \\
\hline 117.2 & 122 & 8 & & 12 & & $120-130$ & & 55 & 57 & 1 & & Prehistoric & Chert & Unknown & Debitage & $\begin{array}{l}\text { Secondary } \\
\text { Flake }\end{array}$ & \begin{tabular}{|l|} 
Distal Fragment \\
\end{tabular} & na & na & na & na & na & na \\
\hline 117.3 & 122 & 8 & & 12 & & $120-130$ & & 55 & 57 & 2 & & Prehistoric & Chert & Unknown & Debitage & Tertiary Flake & Proximal Fragment & na & na & na & na & na & na \\
\hline 117.4 & 122 & 8 & & 12 & & $120-130$ & & 55 & 57 & 1 & & Prehistoric & Chert & Unknown & Debitage & \begin{tabular}{|l|} 
Tertiary Flake \\
\end{tabular} & Distal Fragment & na & na & na & na & na & na \\
\hline 117.5 & 122 & 8 & & 12 & & $120-130$ & & 55 & 57 & 1 & & Prehistoric & Metaquartzite & Unknown & Debitage & \begin{tabular}{|l|} 
Secondary \\
Flake
\end{tabular} & Complete & na & na & na & na & na & na \\
\hline 118.1 & 109 & 9 & & 8 & & $80-90$ & & 54 & 56 & 1 & & Prehistoric & Chert & Unknown & Debitage & Tertiary Flake & Complete & na & na & na & na & na & na \\
\hline
\end{tabular}


Appendix B: Lithic Analysis for 41SM385

\begin{tabular}{|c|c|c|c|c|c|c|c|c|c|c|c|c|c|c|c|c|c|c|c|c|c|c|c|}
\hline Lot No. & FS No. & $\begin{array}{l}\text { Unit } \\
\text { No. }\end{array}$ & $\begin{array}{l}\text { ST } \\
\text { No }\end{array}$ & Level & $\begin{array}{l}\text { Depth } \\
\text { (cmbs) }\end{array}$ & \begin{tabular}{|c|} 
Depth \\
(cmbd)
\end{tabular} & Provience & Northing & Easting & $\begin{array}{c}\text { No. of } \\
\text { Specimens }\end{array}$ & $\begin{array}{l}\text { Time } \\
\text { Period }\end{array}$ & Era/Phase & Artifact Material & Use Context & $\begin{array}{c}\text { Artifact } \\
\text { Description }\end{array}$ & $\begin{array}{l}\text { Artifact Sub- } \\
\text { description }\end{array}$ & $\begin{array}{c}\text { Artifact } \\
\text { Form/Condition }\end{array}$ & \begin{tabular}{|c} 
Surface \\
Treatment
\end{tabular} & Comments & $\begin{array}{c}\text { Weight in } \\
\text { grams }\end{array}$ & $\begin{array}{c}\text { Length in } \\
\mathrm{mm}\end{array}$ & $\begin{array}{c}\text { Width in } \\
\mathrm{mm}\end{array}$ & $\begin{array}{c}\text { Thickness in } \\
\mathrm{mm}\end{array}$ \\
\hline 118.2 & 109 & 9 & & 8 & & \begin{tabular}{|l|l|}
$80-90$ \\
\end{tabular} & & 54 & 56 & 1 & & Prehistoric & Chert & Unknown & Debitage & Tertiary Flake & Medial Fragment & na & na & na & na & na & na \\
\hline 118.3 & 109 & 9 & & 8 & & $80-90$ & & 54 & 56 & 1 & & Prehistoric & Metaquartzite & Unknown & Debitage & Tertiary Flake & Proximal Fragment & na & na & na & na & na & na \\
\hline 119.1 & 111 & 9 & & 9 & & |90-100 & & 54 & 56 & 1 & & Prehistoric & Chert & Unknown & Debitage & Tertiary Flake & Proximal Fragment & na & na & na & na & na & na \\
\hline 119.2 & 111 & 9 & & 9 & & |90-100 & & 54 & 56 & 1 & & Prehistoric & Metaquartzite & Unknown & Debitage & Tertiary Flake & Proximal Fragment & \begin{tabular}{|l} 
Thermally \\
Altered
\end{tabular} & na & na & na & na & na \\
\hline 120.1 & 112 & 9 & & 10 & & 100-110 & & 54 & 56 & 1 & & Prehistoric & Chert & Unknown & Debitage & Tertiary Flake & Complete & \begin{tabular}{|l|} 
Thermally \\
Altered
\end{tabular} & na & na & na & na & na \\
\hline 120.2 & 112 & 9 & & 10 & & $\mid 100-110$ & & 54 & 56 & 1 & & Prehistoric & Chert & Unknown & Debitage & Tertiary Flake & Complete & na & na & na & na & na & na \\
\hline 120.3 & 112 & 9 & & 10 & & 100-110 & & 54 & 56 & 1 & & Prehistoric & Chert & Unknown & Debitage & Tertiary Flake & Medial Fragment & na & na & na & 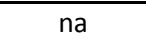 & na & na \\
\hline 120.4 & 112 & 9 & & 10 & & $\mid$ & & 54 & 56 & 1 & & Prehistoric & Metaquartzite & Unknown & Debitage & Tertiary Flake & Proximal Fragment & \begin{tabular}{|l|} 
Thermally \\
Altered
\end{tabular} & na & na & na & na & na \\
\hline
\end{tabular}




\section{Appendix C}

\section{Radiocarbon Dating Analysis}




\title{
REPORT OF RADIOCARBON DATING ANALYSES
}

\author{
Ms. Linda W. Ellis
}

Report Date: 12/21/2010

PBS\&J

Material Received: 11/17/2010

\begin{tabular}{cccc}
\hline Sample Data & Measured & $13 \mathrm{C} / 12 \mathrm{C}$ & Conventional \\
& Radiocarbon Age & Ratio & Radiocarbon Age $(*)$
\end{tabular}

Beta - 288321

$1000+/-40 \mathrm{BP}$

$-26.1 \mathrm{o} / \mathrm{oo}$

$980+1-40 \mathrm{BP}$

SAMPLE : SM385-1

ANALYSIS : AMS-Standard delivery

MATERIAL/PRETREATMENT : (bulk sherd organics): acid washes

2 SIGMA CALIBRATION : $\quad$ Cal AD 990 to 1160 (Cal BP 960 to 790)

Beta - 288322

$1630+/-40 \mathrm{BP}$

$-22.0 \mathrm{o} / 00$

$1680+/-40 \mathrm{BP}$

SAMPLE : SM385-2

ANALYSIS : AMS-Standard delivery

MATERIAL/PRETREATMENT : (bulk sherd organics): acid washes

2 SIGMA CALIBRATION :

Cal AD 250 to 430 (Cal BP 1700 to 1520 )

Beta -288323

$580+/-40 \mathrm{BP}$

$-26.2 \mathrm{o} / \mathrm{oo}$

$560+/-40 \mathrm{BP}$

SAMPLE : SM385-4

ANALYSIS : AMS-Standard delivery

MATERIAL/PRETREATMENT : (bulk sherd organics): acid washes

2 SIGMA CALIBRATION : Cal AD 1300 to 1370 (Cal BP 650 to 580) AND Cal AD 1380 to 1430 (Cal BP 570 to 520)

Beta - 288324

$900 \div /-40 \mathrm{BP}$

$-26.2 \mathrm{o} / \mathrm{oo}$

$880+1-40 \mathrm{BP}$

SAMPLE : SM385-3

ANALYSIS : AMS-Standard delivery

MATERIAL/PRETREATMENT : (bulk sherd organics): acid washes

2 SIGMA CALIBRATION : $\quad$ Cal AD 1040 to 1240 (Cal BP 920 to 700)

Dates are reported as RCYBP (radiocarbon years before present, "present" $=A D$ 1950). By international convention, the modern reference standard was $95 \%$ the $14 \mathrm{C}$ activity of the National Institute of Standards and Technology (NIST) Oxalic Acid (SRM 4990C) and calculated using the Libby $14 \mathrm{C}$ half-life ( 5568 years). Quoted errors represent 1 relative standard deviation statistics (68\% probability) counting errors based on the combined measurements of the sample, background, and modern reference standards. Measured $13 \mathrm{C} / 12 \mathrm{C}$ ratios (delta 13C) were calculated relative to the PDB-1 standard.
The Conventional Radiocarbon Age represents the Measured Radiocarbon Age corrected for isotopic fractionation, calculated using the delta $13 \mathrm{C}$. On rare occasion where the Conventional Radiocarbon Age was calculated using an assumed delta $13 \mathrm{C}$, the ratio and the Conventional Radiocarbon Age will be followed by "*n. The Conventional Radiocarbon Age is not calendar calibrated. When available, the Calendar Calibrated result is calculated from the Conventional Radiocarbon Age and is listed as the "Two Sigma Calibrated Result" for each sample. 


\section{CALIBRATION OF RADIOCARBON AGE TO CALENDAR YEARS}

(Variables: $\mathrm{C} 13 / \mathrm{C} 12=-26.1: \mathrm{lab} . \mathrm{mul} \mathrm{t}=1$ )

\section{Laboratory number: Beta-288321}

\section{Conventional radiocarbon age: $980 \pm 40 \mathrm{BP}$}

2 Sigm a calibrated result: Cal AD 990 to 1160 (Cal BP 960 to 790) (95\% probability)

\section{Intercept data}

Intercept of radiocarbon age

with calibration curve:

1 Sigm a calibrated results: Cal AD 1020 to 1040 (Cal BP 930 to 910) and (68\% probability)

Cal AD 1030 (Cal BP 920)

Cal AD 1100 to 1120 (Cal BP 850 to 830 )

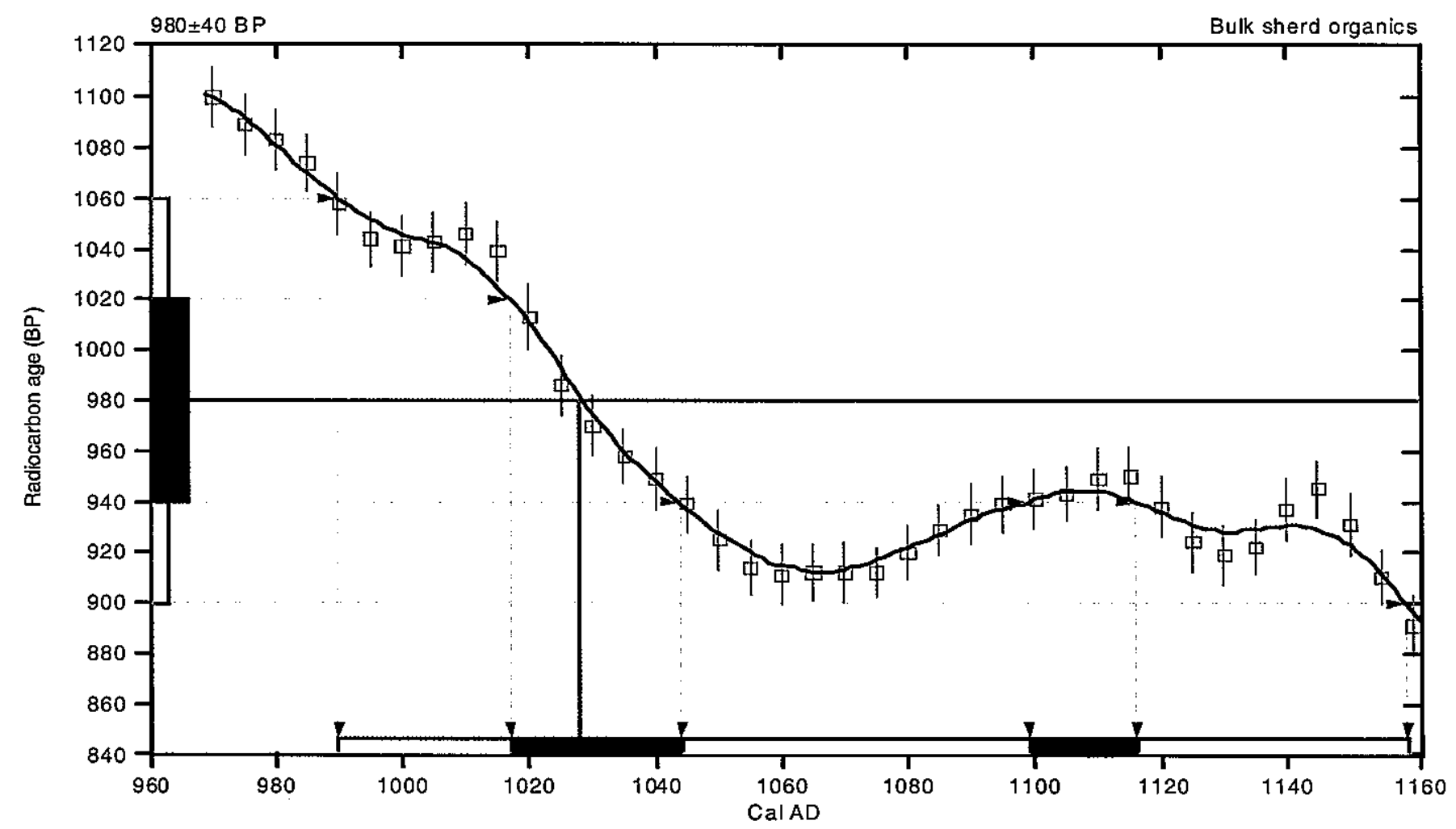

References:

Database used INTCALO4

Calibration Database

INT CALO4 Radiocarbon Age Calibration

IntCal04: Calibration Issue of Radioca rbon (Volume 46, nr 3, 2004).

Mathem atics

A Simplified App roach to Calibrating C14 Dates

Talma, A. S., Vogel, J. C., 1993, Radiocarbon 35(2), p317-322

\section{Beta Analytic Radiocarbon Dating Laboratory}

4985 S.W. 74th Court, Miami, Florida 33155 -Tal: (305)667.5167•Fax: (305)663-0964 - E-Mail: beta@ radiocarbon.com 


\section{CALIBRATION OF RADIOCARBON AGE TO CALENDAR YEARS}

(Variables: C13/C 12 $=-22$ :lab. mult $=1$ )

\section{Laboratory number: Beta-288322}

\section{Conventional radiocarbon age: $1680 \pm 40 \mathrm{BP}$}

2 Sigm a calibrated result: Cal AD 250 to 430 (Cal BP 1700 to 1520) (95\% probability)

\section{Intercept data}

Intercept of radiocarbon age

with calibration curve: Cal AD 390 (Cal BP 1560)

1 Sigma calibrated result: Cal AD 330 to 410 (Cal BP 1620 to 1540 )

(68\% probability)

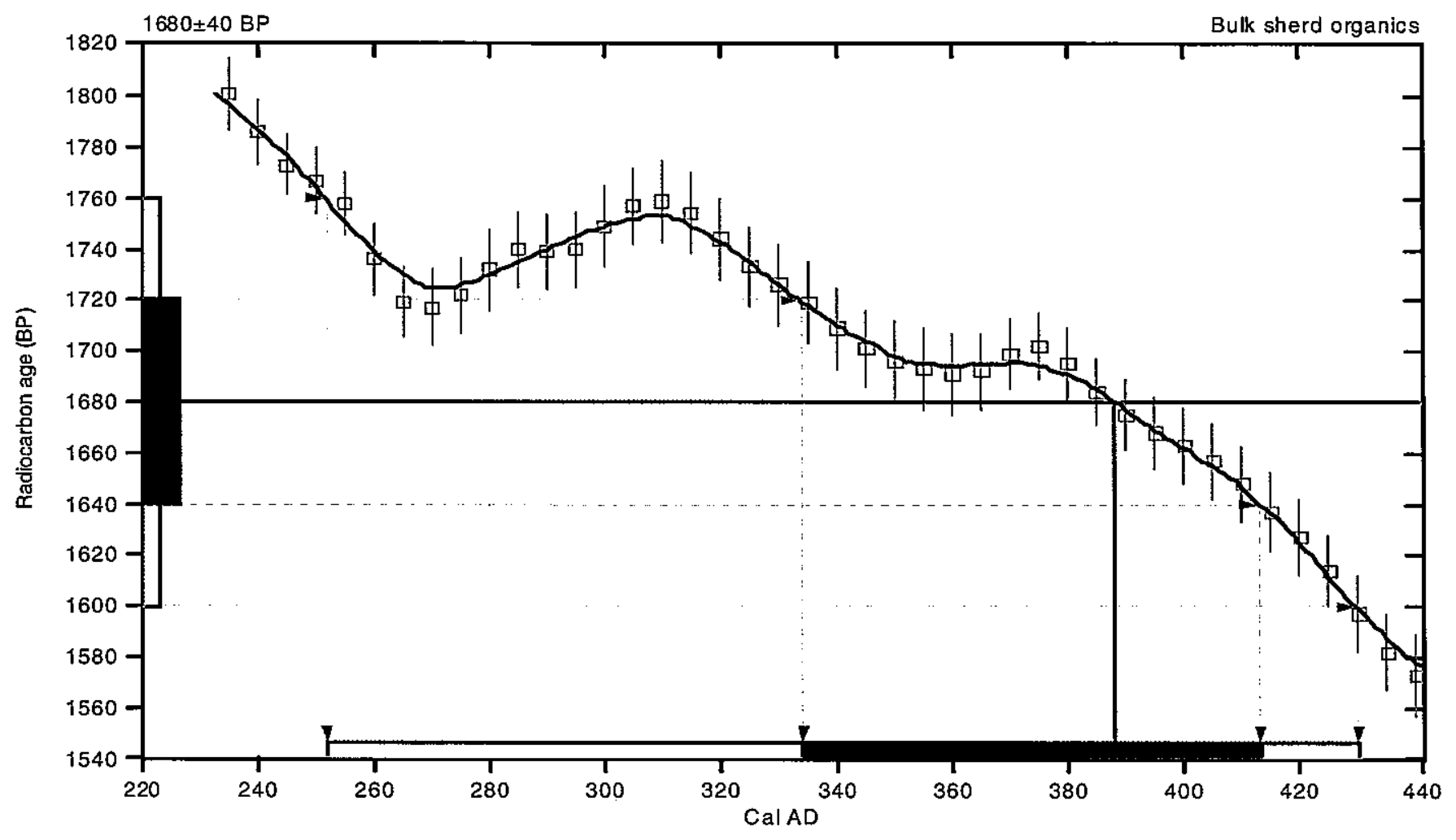

References:

Database used INTCALO4

Calibration Database

INTCAL04 Radiocarbon Age Calibration

IntCal04: Calibration Issue of Radioca rbon (Volume 46, nr 3, 2004).

Mathematics

A Simplified Approach to Calibrating C14 Dates

Talma, A. S., Vogel, J. C., 1993, Radioca rbon 35(2), p317-322

\section{Beta Analytic Radiocarbon Dating Laboratory}

4985 S.W.74th Court, Miami, Florida 33155 - Tel: (305)667-5167 • Fax: (305)663-0964 • E-Mail: beta@ radiocarbon.com 


\section{CALIBRATION OF RADIOCARBON AGE TO CALENDAR YEARS}

(Variables: C13/C 12=-26.2:lab. mult=1)

Laboratory number: Beta-288323

\section{Conventional radiocarbon age: $560 \pm 40 \mathrm{BP}$}

2 Sigm a calibrated results: Cal AD 1300 to 1370 (Cal BP 650 to 580) and

(95\% probability) Cal AD 1380 to 1430 (Cal BP 570 to 520)

Intercept data

Intercept of radiocarbon age

with calibration curve:

1 Sigma calibrated results: Cal AD 1320 to 1350 (Cal BP 630 to 600) and

(68\% probability) Cal AD 1390 to 1420 (Cal BP 560 to 530)

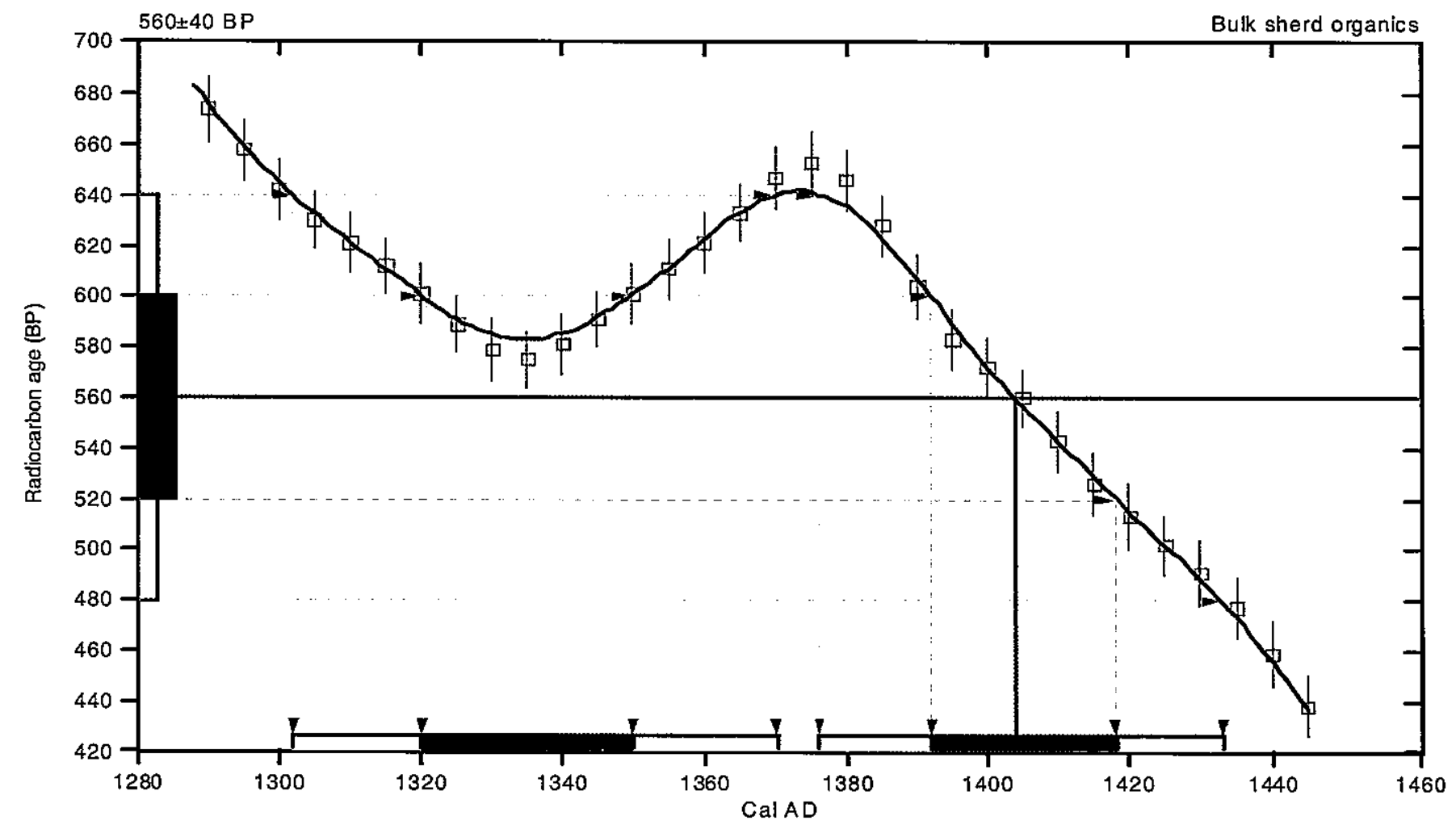

References:

Database used

INTCALO4

Calibration Database

INTCALO4 Radiocarbon Age Calibration

IntCa 104: Calibration Issue of Radioca rbon (Volume 46, nr 3, 2004).

Mathematics

A Simplified Approach to Calibrating C14 Dates

Talma, A. S., Vogel, J. C., 1993, Radioca rbon 3S(2), p317-322

4985 S.W. 74th Court, Miami, Florida 33155·Tel: (305)667-5167•Fax: (305)663-0964 - E-Mail: beta@ radiocarbon.com 


\section{CALIBRATION OF RADIOCARBON AGE TO CALENDAR YEARS}

(Variables: $\mathrm{C} 13 / \mathrm{C} 12=-26.2: \mathrm{lab} . \mathrm{mult}=1$ )

Laboratory number: Beta-288324

Conventional radiocarbon age: $880 \pm 40 \mathrm{BP}$

2 Sigm a calibrated result: Cal AD 1040 to 1240 (Cal BP 920 to 700) (95\% probability)

Intercept data

Intercept of radiocarbon age with calibration curve:

Cal AD 1170 (Cal BP 780)

1 Sigma calibrated results: Cal AD 1060 to 1080 (Cal BP 900 to 870) and (68\% probability) Cal AD 1150 to 1210 (Cal BP 800 to 740)

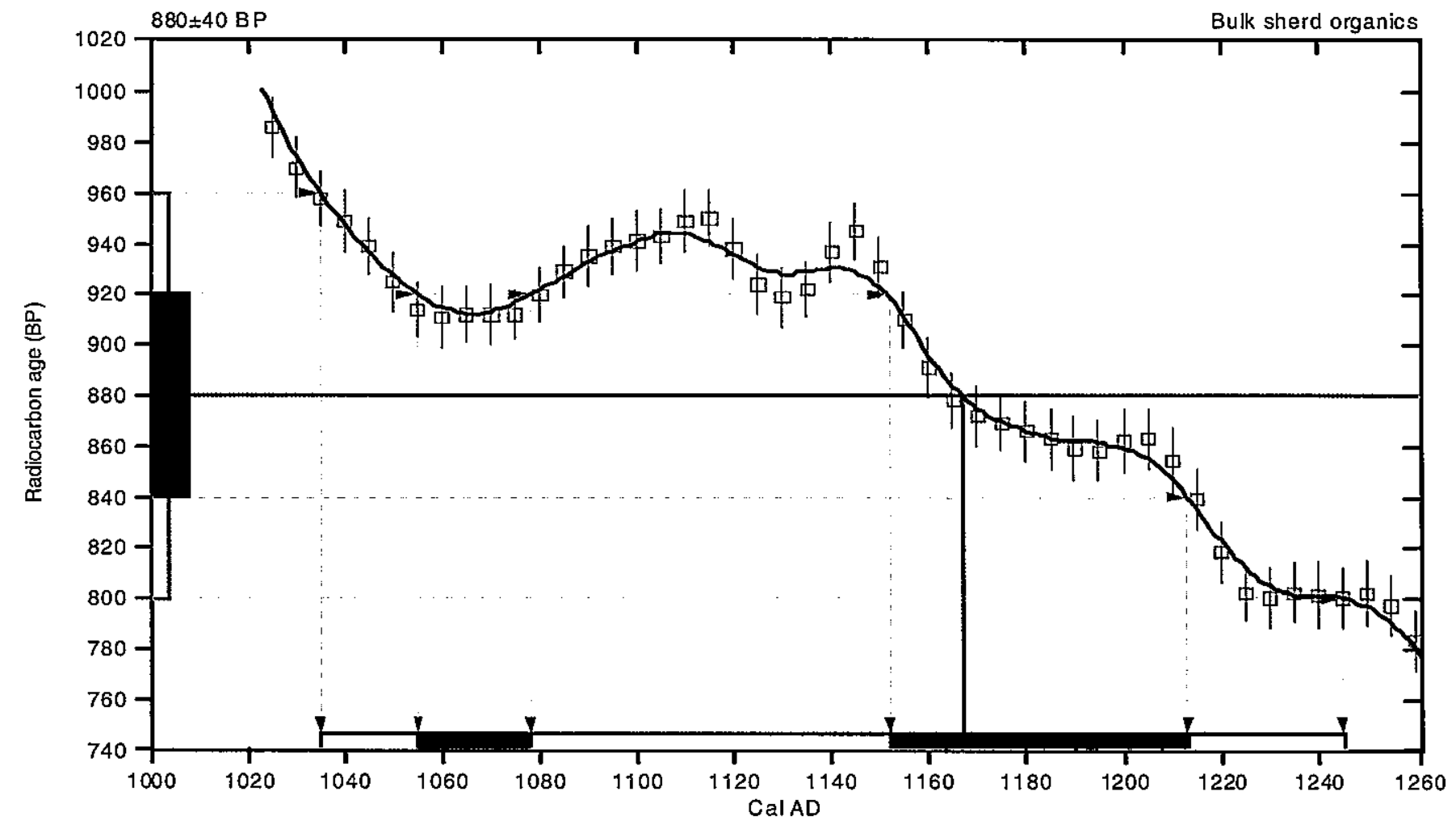

References:

Database used INTCALO4

Calibration Databa se

INTCAL04 Radiocarbon Age Calibration

IntCa 104: Calibration Issue of Radioca rbon (Volume 46, nr 3, 2004).

Mathematics

A Simplified App roach to Calibrating C14 Dates

Talma, A. S., Vogel, J. C., 1993, Radioca rbon 35(2), p317-322

\section{Beta Analytic Radiocarbon Dating Laboratory}

4985 S.W.74th Court, Miami, Florida $33155 \cdot$ Tel: (305)667-5167•Fax: (305)663-0964 • E-Mail: beta@ radiocarbon.com 


\section{Appendix D}

Site Location

(not for public disclosure) 